\author{
Universidade de São Paulo \\ Escola de Comunicações e Artes \\ Departamento de Jornalismo e Editoração
}

\title{
Vida Íntima em Cartaz - espaços da mídia para as narrativas de histórias pessoais do homem comum
}

\section{Lígia Maria Trigo-de-Souza}

Tese apresentada como requisito parcial para a obtenção do título de Doutor em Ciências da Comunicação, Área de Interfaces Sociais da Comunicação, Linha de Pesquisa Tecnologias da Comunicação e Redes Interativas, sob a orientação da Profa. Dra. Elizabeth N. Saad Corrêa.

SÃO PAULO

2007 
BANCA EXAMI NADORA 


\section{RESUMO}

Esta tese visa a analisar os espaços que os meios de comunicação destinam à narrativa das histórias pessoais do seu público feita por eles mesmos e o grau de mediação praticado por essas mídias na publicação/veiculação dessas histórias. Para comprovar a hipótese central, de que os espaços oferecidos para os relatos de histórias pessoais variam de mídia para mídia e, no entanto, os critérios de seleção adotados pelos diversos meios de comunicação são praticamente comuns e reproduzem os critérios de noticiabilidade jornalística (interesse e adequação da história ao público do veículo), procedemos ao resgate do fenômeno (em suas vertentes histórica, psicológica, sociológica e antropológica) e a análise de casos emblemáticos em cada mídia.

Palavras-chave: Histórias pessoais, Meios de Comunicação, Mediação, História da mídia e Narrativas participativas. 


\section{ABSTRACT}

This thesis aims to analyse the spaces that the communication media devote to the narration of its public personal stories made by themselves and the mediation grade practiced by these media in the publication/transmission of these stories. To authenticate the central hypothesis, that the spaces offered to the account of personal stories vary from medium to medium and, however, the selection standards adopted by the many media are practically common and reproduce the journalistic newsworthiness standards (interest and adjustment of the story to the public of the media), we proceed to the phenomenon rescue (in its historical, psychological, sociological and anthropological bases) and the analyses of emblematic cases in each media.

Key-words: Personal stories, Media, Mediation, History of Media and Participative Narrative. 
Para Lísia (in memoriam) - para sempre no meu coração.

Para meus pais, João e Maria José, e minha irmã, Edda. 


\section{agradecimentos}

Quando se termina um trabalho, fazer a relação das pessoas a quem devemos agradecer pelos diversos tipos de apoio que recebemos no processo não é das tarefas mais fáceis. Principalmente para quem já teve uma vivência anterior e percebeu que, por mais que se tente, sempre, por um motivo ou outro, acabamos esquecendo alguém que teve um papel importante nesta fase. Assim, gostaria de começar já me desculpando com aqueles que, porventura, eu deixe de mencionar aqui. Terá sido, não por falta de gratidão ou reconhecimento mas, mais uma vez, pela dificuldade de anotar tudo ao longo do processo e a pressa de finalizar o trabalho.

A origem deste trabalho remonta à minha fase de mestrado (1999-2002). Foi ali que iniciei minha convivência com a Profa. Dra. Beth Saad ainda em uma relação de professora-aluna. Em suas aulas, obtive o contato necessário com teorias e pesquisas que trouxeram inquietações e acabaram gerando o projeto desta pesquisa. Depois, já na relação de Orientadora-orientanda, tive sua interlocução sagaz e precisa em todos os momentos cruciais do desenvolvimento da tese. Beth alternou papéis de conselheira, leitora-crítica, terapeuta, e me ensinou que o papel de orientar alguém em sua busca pelas respostas às inquietações acadêmicas transcende, em muito, à indicação de caminhos bibliográficos, referenciais teóricos e a modelos metodológicos. Sou profundamente grata a ela. Se eu posso entregar hoje um trabalho que me orgulho de ter escrito, sem sombra de dúvidas, foi graças à sua orientação. 
Agradeço também à Banca do meu Exame de Qualificação que me ajudou a materializar esta tese e me ofereceu contribuições que enriqueceram muito o trabalho apresentado.

No CJE, Tânia e Paulo são apoios a toda prova. Ajudam-nos a superar nossas "neuras" da pós e ainda a entender e não perder prazos, lidar com sistemas, corrigir erros. São nossos anjos da guarda.

No meu trabalho, na Faculdade de Medicina, foram inúmeras as contribuições de todos à minha volta. Solidariedade, apoio e participação nas preocupações e soluções. Agradeço particularmente às palavras de incentivo dos Profs. Drs. Flávio Fava de Moraes, Giovanni Guido Cerri, Marcos Boulos, Raymundo Soares de Azevedo e Yassuhiko Okay. E à infinita paciência de Maggie, Patrícia, Rosana, Wal, dr. Agenor, Mariana, Samantha, Dayanne e Claudinei.

São co-autores deste trabalho os funcionários do Serviço de Biblioteca e Documentação da FMUSP - Faculdade de Medicina da USP que, através do sistema de Empréstimos entre Bibliotecas, garantiram que eu pudesse realizar minhas consultas sem a necessidade de deslocamento entre os campi. Em particular, Marinalva e Márcia que buscaram de todas as maneiras fazer com que o material que eu necessitava estivesse em minhas mãos em prazos recordes. Marinalva, especialista em regras da ABNT, ainda funcionou como um plantão tira-dúvidas, principalmente na fase final do trabalho. Também do SBD, Altair chegou até a, 
gentilmente, buscar material para que eu pudesse conciliar a pesquisa com minhas atividades profissionais.

Maria Crestana e Marli Bortot foram amigas como poucos poderiam ser. Em nenhum momento aceitaram minhas manifestações de desânimo e se envolveram, pessoalmente, na busca de soluções para tudo que eu apresentava como problemas. Além de tudo isso, sou grata pelo senso de humor da Maria e a serena convicção da Marli que me ajudaram a seguir em frente.

Várias pessoas me ajudaram indicando casos e fontes e até mesmo facilitando meu contato com elas. Em especial, Sílvia Candal, Renato Levi e Marcos Cripa.

Minha família - meus pais e minha irmã - sempre foram meu sul e meu norte, os autores primeiros de tudo que sou e que ainda espero ser. São mais que presentes em todas as situações da minha vida e no doutorado não foi diferente. Em particular, para o meu pai, a conclusão desta etapa é a concretização de um sonho. Sou muito grata a eles, não só por esta fase. 
“Tal como os indivíduos expressam sua vida, assim são eles." (Karl Marx; Friedrich Engels. A ideologia alemã) 


\section{SUMÁRIO}

$\begin{array}{ll}\text { I ntrodução } & 17\end{array}$

I - Sobre a tese 23

1. Objeto e J ustificativa 25

2. Metodologia 36

II - Falando de nós 57

1. Contextualização e Histórico 59

2. Por que contamos nossas histórias? 73

3. Por que contamos nossas histórias na mídia? 84

III - Histórias pessoais e Mídia 93

1. O sistema midiático contemporâneo 95

2. Mídia I mpressa 118

$\begin{array}{ll}\text { a. Mídia I mpressa e Histórias Pessoais em } & 132 \\ 2007 & 155\end{array}$

3. Mídia Eletrônica 155

a. Mídia Eletrônica e Histórias Pessoais em 2007

4. Mídia Digital 197

IV - Estudos de Caso 221

1. Eu, leitora - Revista Marie Claire 223

2. Revista Sou + Eu! 236

3. Que Saudade de Você! - Rádio Capital 246

4. Casos de Família - SBT 261

5. Viva SP - Comunidade Virtual 278

6. Puzzle Diário - Blog 290

V - Conclusões 303

$\begin{array}{ll}\text { Bibliografia } & 315\end{array}$

$\begin{array}{ll}\text { Anexos } & 343\end{array}$ 


\section{NTRODUÇÃO}

Este trabalho surgiu da observação do espaço crescente que as histórias pessoais têm ocupado na mídia e da necessidade de entender este fenômeno do ponto de vista do processo comunicacional. Principalmente a partir da expansão das Novas Tecnologias da Comunicação, o fenômeno passou a ocupar, não só os espaços da mídia propriamente, mas também os espaços da discussão em torno das questões midiáticas.

De um lado, a chamada Indústria da Interatividade (associada às febres dos relacionamentos e da colaboração) vem aquecendo a pauta acadêmica com os debates sobre que tipo de ação pode efetivamente ser considerada interativa e o quanto cada Meio de Comunicação permite ao público participar de sua própria elaboração. No entanto, se não podemos negar que vivemos um processo de mitificação dessa participação do público nos meios de comunicação, devemos observar que cada mídia tem apresentado um comportamento específico em relação a este fenômeno e os graus de mediação impingidos ao processo têm sido variáveis.

De outro lado, a exposição da vida pessoal (antes considerada privada) de famosos e celebridades ao lado de anônimos vem ocupando espaço crescente nos mais diversos veículos dos Meios de Comunicação. Fenômeno de caráter global, essa vitrine da vida privada tem também sua acentuação a partir da expansão das Novas Tecnologias de Comunicação, em particular com a criação dos blogs, onde se multiplicavam exemplos de autores desconhecidos, surgidos do próprio público, e dispostos a dividir com leitores suas impressões, sentimentos e experiências de vida. Comparados inicialmente aos diários íntimos, publicados em 
forma de livros, os blogs de pessoas anônimas provocaram, inegavelmente, um aquecimento deste tipo de espaço nos demais Meios de Comunicação.

Esta constatação levou à primeira delimitação do objeto pesquisado: como o modelo de blogs permite a comunicação direta do autor anônimo com os demais internautas, buscamos nas demais mídias exemplos em que a narrativa também fosse feita de forma mais direta possível a partir do relato enviado (de forma estimulada ou não) pelo público. Buscamos em cada tipo de mídia enfocada - impressa (jornais e revistas), eletrônica (rádio e televisão) e mesmo digital (além dos blogs, analisamos comunidades virtuais) - as experiências em que a transmissão da história se dá com o menor grau de mediação possível.

Também procuramos centrar nossa pesquisa na história do cidadão comum e não das celebridades que figuram nas capas das nossas publicações. O objetivo é focar a análise dos fatores de noticiabilidade no conteúdo de cada relato e no espaço destinado a cada narrativa e não na importância dada a cada autor pela mídia, o que seria impossível em se tratando de autores não-anônimos.

Nossa hipótese, que acreditamos comprovar ao longo deste trabalho, é que os espaços oferecidos para os relatos de histórias pessoais variam de mídia para mídia, assim como o grau de mediação impingida por elas; no entanto, os critérios de seleção adotados pelos diversos meios de comunicação são praticamente comuns e reproduzem os critérios de noticiabilidade jornalística (interesse e adequação da história ao público do veículo).

Partimos do pressuposto de que a busca pela divulgação de sua vida e de seus feitos sempre acompanhou a humanidade. No entanto, o desenvolvimento dos meios de comunicação de massa e seu posicionamento como centro da sociedade 
contemporânea contribuíram para o aumento desta necessidade e criaram novos espaços para isso.

Em nossa análise, enfocamos o desenvolvimento deste fenômeno através de três vertentes principais: a psicológica, a sociológica e a antropológica. Do ponto de vista psicológico, nosso enfoque relata a necessidade do ser humano em ter a confirmação de sua existência (e sua reinvenção) a partir dos olhos do outro'; a conquista da importância frente aos seus pares²; e a sutura da alteridade a partir dos instrumentos oferecidos a partir da Modernidade ${ }^{3}$.

Do ponto de vista sociológico, a nova configuração dos espaços público e privado e a nova fundamentação dos conceitos de privacidade e intimidade são a base de sustentação deste trabalho.

Já na vertente antropológica, abordamos a manutenção da prática de registro do cotidiano e a substituição das paredes das cavernas pelos meios de comunicação que, culturalmente, passam a ocupar o centro de nossa sociedade contemporânea.

Essas análises acompanham um pequeno histórico das histórias pessoais e seu desenvolvimento até chegar à contemporaneidade.

Os Meios de Comunicação têm espaços e formas diversas para tratar os relatos pessoais. No entanto, todos oferecem algum grau de mediação, sendo essa mais humana ou

\footnotetext{
${ }^{1}$ Tal qual a questão do outro como um espelho de confirmação da existência é relatada por LACAN (Cf. 1985).

${ }^{2}$ Tal qual na sociedade grega, onde os cidadãos buscavam destaque diante dos demais na praça pública, na sociedade moderna/contemporânea, esse destaque é buscado nos meios de comunicação que, de acordo com HABERMAS (Cf. 1984), substituíram a praça pública.

${ }^{3}$ MATTELART (Cf. 2002) aponta para a substituição no papel de religar os seres humanos destinado a Deus na era Medieval pelos Meios de Comunicação na era Moderna.
} 
tecnológica, dependendo das características do meio. Numa perspectiva histórica, podemos considerar que os meios digitais são os que menos aplicam a mediação humana tradicional dos veículos de comunicação na publicação dos relatos, utilizando, em alguns casos, apenas a mediação tecnológica. Nos meios impressos, ao contrário, a mediação humana é fortemente utilizada.

O crescimento dos espaços destinados às histórias pessoais nos meios de comunicação, principalmente a partir das novas tecnologias de comunicação e particularmente nos meios digitais, confere a esses relatos valores de noticiabilidade jornalística.

Analisamos neste trabalho os espaços que cada tipo de mídia (impressa, eletrônica e digital) oferece ao público para participar de sua elaboração, os espaços que são destinados aos relatos de histórias pessoais e, finalmente, quais os espaços destinados às histórias pessoais narradas pelo próprio público.

À análise desses espaços são acrescentadas experiências (seções, programas, quadros etc.), frutos da pesquisa empreendida sobre o desenvolvimento de cada meio de comunicação. No entanto, frente ao tamanho do universo pesquisado e à falta de documentação específica sobre essa participação, não se trata propriamente de uma documentação histórica e sim de fragmentos que podem indicar caminhos para uma pesquisa futura.

A tese traz ainda um retrato instantâneo da mídia no que se refere às narrativas do próprio público na época atual (2007) através do acompanhamento das principais publicações (as de maior circulação), rádios, TVs e produtos comunicacionais da Internet (os de maior audiência). São apresentados os perfis 
desses espaços bem como destacadas as experiências de maior relevância.

Finalmente, apresentamos seis Estudos de Caso englobando todos os meios pesquisados. Em Mídia Impressa, selecionamos: “Eu, leitora”, da revista Marie Claire e matérias de destaque da revista Sou + Eu!. Em Mídia Eletrônica: o quadro "Que Saudade de Você!", do programa "Eli Correa", da Rádio Capital, e o programa "Casos de Família", do SBT. Em Mídia Digital: a comunidade virtual "Viva SP" e o blog "Puzzle Diário". 


\section{SOBRE A TESE}

"Retirar o significado da experiência e buscar torná-lo atuante é, em verdade, nosso processo de crescimento.

Recebemos e recriamos alguns desses significados. Outros brotam de nós mesmos e importa que tentemos comunicá-los. A crise humana é sempre uma crise de compreensão: o que verdadeiramente compreendemos, podemos fazer." (Raymond Williams. Cultura e Sociedade) 


\section{Objeto e J ustificativa}

O objeto central deste trabalho são as histórias pessoais narradas pelo próprio público, publicadas/veiculadas pelos Meios de Comunicação e analisadas sob a perspectiva de que tipo de mediação a narrativa inicial (do próprio autor) sofreu até sua divulgação pelo meio de comunicação.

Entendemos por mediação todo 0 processo de manipulação humana e tecnológica do relato original até sua veiculação, compreendendo a seleção das histórias, sua edição, adequação à linguagem e/ou à mídia onde será veiculado e até mesmo sua reinterpretação por parte do profissional de comunicação que está narrando a história.

A definição do nosso objeto passa, inicialmente, pela delimitação do que entendemos por história pessoal representada/narrada pelas mídias.

Historicamente, o fenômeno de contar a sua história pessoal tem sua marca na modernidade (embora exista muito anteriormente) e adquire visibilidade a partir da expansão dos diários pessoais ${ }^{4}$, publicados em forma de livros, que passam a constituir uma categoria literária (muito embora, às vezes, objeto de discriminação por parte dos críticos de Literatura).

Esses diários serão importantes, nesta Tese, para fins de contextualização e compreensão histórica, inclusive mostrando a origem do fenômeno que constitui o cerne de nossa pesquisa: as narrativas pessoais que são apresentadas pela mídia em geral. $\mathrm{Na}$

\footnotetext{
${ }^{4}$ Esta questão será aprofundada na Parte II - Falando de nós, Capítulo 1. Contextualização e Histórico.
} 
migração da forma inicial de registro íntimo e particular para a veiculação midiática, a narrativa das histórias pessoais apresentará uma série de condicionamentos e características que são importantes para fins de delimitação do objeto pesquisado.

A primeira dessas características é a periodicidade. Nos diários pessoais tradicionais, o registro é feito em entradas periódicas, em que o dia-a-dia é registrado cotidianamente embora sua publicação reúna todos os registros em um só volume. A periodicidade aqui aparece no registro e não em sua publicação.

Já nos Meios de Comunicação (até a entrada em cena da internet ${ }^{5}$ ) as histórias pessoais são registradas como episódios de vida, numa forma de registro mais semelhante à da autobiografia em que há um debruçar-se sobre o passado, com exceção aos programas de "consultório sentimental" (muito freqüentes no rádio e na TV) em que pessoas narram seus problemas/conflitos atuais em busca de conselhos, misturando o passado e o presente. Não há, portanto, periodicidade no registro de uma única história.

No entanto, somadas aos demais relatos também divulgados por aquela mídia, adquirem periodicidade (como sessões, colunas, quadros de programas etc) e constituem-se num grande diário coletivo. Portanto, podemos pensar numa periodicidade de publicação/veiculação.

Por outro lado, a falta de periodicidade no registro de uma única história somada à falta de espaço nas publicações/programações, faz com que as histórias sejam condensadas, com narrativas mais curtas (muitas vezes relacionadas a apenas uma experiência ou fase da vida e mais condensadas que em um relato completo de um diário). Mais uma

\footnotetext{
${ }^{5}$ A exceção da internet é caracterizada pelos blogs, que permitem a estruturação da narrativa de modo semelhante a dos diários pessoais.
} 
vez aqui, devemos destacar a exceção vivida pela internet já que a questão do espaço (e a falta dele) não é preponderante nesta mídia, sendo substituída por questões como banda de acesso, velocidade etc. .

Outro ponto a ressaltar é que, mesmo apropriadas pelos Meios de Comunicação, essas narrativas podem manter suas características Literárias (a própria definição do jornalismo literário como gênero indica a incorporação de recursos literários ao discurso jornalístico). Entre elas podemos destacar a construção de personagens a partir das histórias de vida do público narradas de forma a retratar um determinado aspecto da sociedade:

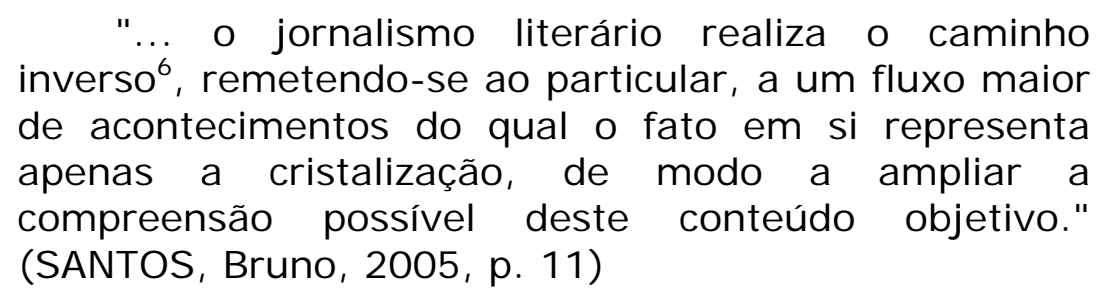

A partir desta definição sobre a construção da história, podemos delimitar um pouco melhor nosso objeto ao responder à pergunta: de quais personagens interessam as histórias?

Em primeiro lugar é importante ressaltar que o foco principal deste trabalho está no processo de retratação pela mídia das histórias pessoais do público (no sentido de audiência, receptor) em si retratadas pela mídia e não no conteúdo objetivo que possa ser apreendido a partir deste relato.

Assim, buscamos as experiências em que cada Meio de Comunicação, dentro de suas características próprias, oferece as melhores condições para que estas histórias cheguem até o público da maneira mais integral e com o menor grau de mediação possíveis.

\footnotetext{
${ }^{6} \mathrm{O}$ autor refere-se ao inverso do caminho adotado pela Antropologia Interpretativa.
} 
Para isto, precisamos diferenciar os vários tipos de participação do público nos Meios de Comunicação, muitos que, inclusive, não podem ser considerados como inserções de histórias pessoais na mídia.

Com o advento da Indústria da Interatividade7, cada vez mais, os Meios de Comunicação procuram criar espaços para a participação do público em seus programas/edições. Esses espaços trazem desde os relatos pessoais (que interessam neste trabalho) até a participação em forma de escolhas (enquetes, votações etc.), opiniões (fóruns, participação em debates etc.) e até informações (ouvintes-repórter, por exemplo), entre outros. No que se refere a esses últimos modelos (a participação do público oferecendo informações para outros indivíduos - públicos como ele), eles não nos interessam por representarem narrativas do indivíduo em cima de fatos coletivos e não de seu universo particular e íntimo, foco central deste trabalho.

Assim, concentramos nossa atenção nas experiências pessoais dos indivíduos repassadas à sua audiência (leitores, ouvintes, telespectadores, internautas) pelas mídias e a mediação oferecida por cada meio.

São muitos os espaços destinados a esses relatos em nossos Meios de Comunicação. E, embora a busca de espaços para a narrativa das aventuras humanas de cunho pessoal não seja uma fenômeno novo, sua intensificação se dá a partir da Modernidade. O desenvolvimento da impressão e a expansão dos Meios de Comunicação são fatores preponderantes para isto.

\footnotetext{
${ }^{7}$ Nome cunhado a partir da valoração adquirida pelo termo Interatividade, associado, principalmente, aos Meios de Comunicação, em contraposição à crítica ao conceito de massa que, segundo Raymond WILLIAMS (1969, p. 313) adquiriu sentido pejorativo, associado a "populacho crédulo, inconstante, fácil de conduzir e de gosto e hábitos baixos". O que se convencionou hoje chamar Interatividade reúne uma série de experiências e situações que vão da simples reatividade à verdadeira interatividade com o meio.
} 
O primeiro, pela nova possibilidade de reprodutibilidade da obra literária em que se converteu o diário pessoal. E é importante que notemos que, embora escrito sob a égide da intimidade e do segredo, há na escritura de um diário o desejo interior de sua publicação e leitura.

“Protestar que o diário era íntimo - certamente não destinado à publicação, nem póstuma - é uma ingenuidade. Pois compor uma imagem para os outros está se tornando, provavelmente, a poética ${ }^{8}$ ordinária do sujeito moderno: de repente, ela orienta os seus atos autobiográficos, sejam eles privados ou públicos, sejam eles, se públicos, favoráveis ou não aos percalços de sua vida." (CALLI GARIS, 1998, p. 17)

Assim, com a invenção da prensa e a expansão das publicações, esses trabalhos encontraram, tal como outros gêneros literários, possibilidade de divulgação.

Já o segundo fator - a expansão dos Meios de Comunicação - trouxe a possibilidade de, além de revelar sua história pessoal para os demais indivíduos, participar da construção de sua publicação (e mais tarde, com os meios eletrônicos, da programação) favorita.

Além da questão da Interatividade, sobre a qual falamos anteriormente, a participação nos Meios de Comunicação está relacionada à possibilidade de atuação na nova configuração da

\footnotetext{
${ }^{8}$ Segundo a Wikipédia, "Como disciplina teórica, a Poética é o estudo das obras literárias, particularmente as narrativas, que visa a esclarecer suas características gerais, a sua literalidade, criando conceitos que possam ser generalizados para o entendimento da construção de outras obras. Apesar de não ter caráter normativo ela opera implícita ou explicitamente na criação artística. Surge na filosofia antiga com Aristóteles, que a trata como um dos métodos do discurso estudando, no fragmento que restou até nossos dias da tragédia e dela destacando noções fundamentais para a considerações teóricas posteriores, como a distinção (a partir de Platão) entre mimesis, no qual o poeta faz parecer que é um outro (um personagem) quem fala, como p.ex. no texto dramático, e diegesis, no qual o poeta fala por si mesmo, p.ex. na narração em terceira pessoa da composição literária." (POETICA, 2007)
} 
esfera pública9 ${ }^{9}$ ainda que, no caso enfocado neste trabalho, substituindo as questões de interesse geral/social pela retratação da esfera íntima.

“O que importa, de novo, é que a celebridade está se tornando o equivalente contemporâneo do que era a intimidade na aurora do sujeito moderno e acabou sendo mais tarde o sentimento de uma bildung. Ela é a própria consistência do sujeito, o lugar onde ele é sincero. O foro íntimo onde cada um procurava se retirar para existir e consistir é agora o fórum da polis." (CALLIGARIS, 1998, p. 17-8, grifo do autor)

O que era da esfera íntima da vida passa a ser objeto do interesse do público e, portanto, objeto de foco dos Meios de Comunicação ${ }^{10}$. Complementarmente, os espaços oferecidos pelas mídias passam a ser objeto da cobiça dos que querem perpetuar suas histórias ou simplesmente conquistar a celebridade através delas. Com isso, cresce a procura pelo público de espaços onde possam divulgar/publicar/veicular suas histórias.

Esse fator (a procura pelo público dos espaços midiáticos) é primordial para a definição do universo abordado pela nossa pesquisa: as histórias pessoais enfocadas pela mídia que nos interessam não são aquelas construídas/retratadas a partir de um interesse do veículo de comunicação por um determinado assunto dentro do qual aquela história é emblemática. Antes disso, nos interessam as histórias que são narradas pela mídia a partir do relato enviado/escrito pelo próprio personagem/autor que a vivenciou. Assim, descartamos de nosso recorte, todas as experiências de participação que não estão centradas em experiências pessoais e íntimas (como, por exemplo, os ouvintes-

\footnotetext{
${ }^{9}$ Esses conceitos, desenvolvidos por Habermas, serão vistos na Parte II Falando de Nós, Capítulo 1. Contextualização e Histórico.

${ }^{10}$ Como veremos mais à frente, esse foco se dá de maneiras diversas dependendo do veículo e de seus objetivos editoriais e mercadológicos, podendo variar da retratação de um personagem para uma reportagem até a reprodução integral da história de vida em questão.
} 
repórteres que abastecem as emissoras de rádio de informações sobre trânsito e outras questões da cidade mas que não trazem o relato das experiências privadas de vida), assim como aquelas que são narradas a partir de um contexto maior (como é o caso das reportagens do Jornalismo Literário, em que os personagens mostrados são construídos/retratados a partir do interesse por um tema geral).

Para isto, devemos considerar também que esse autor não é uma celebridade e sim o homem comum que vive seu dia-adia sem destaque e tem na mídia a oportunidade de se diferenciar dos demais, deixar de ser massa e projetar suas experiências e histórias pessoais.

O interesse do homem comum em se ver refletido nos Meios de Comunicação tanto reafirma o papel da mídia como o espelho que confirma sua identidade como reforça o papel central que ela ocupa na sociedade. Afinal, é através dela que ele tem sua existência confirmada: nada existe se não está na mídia.

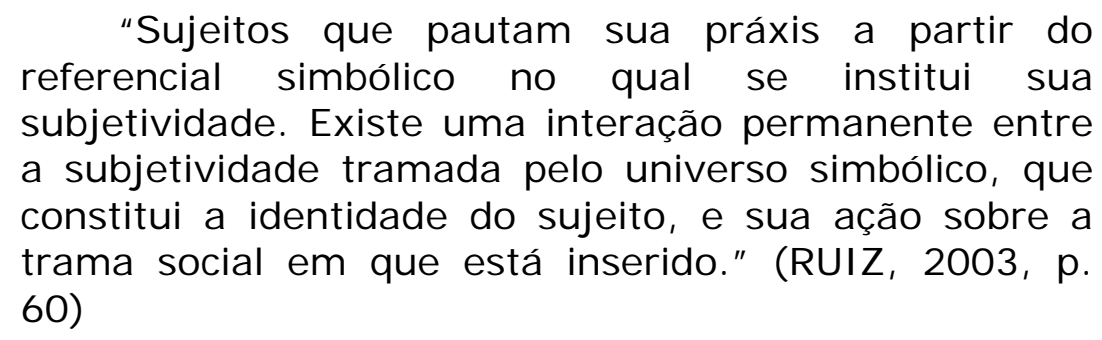

Hannah ARENDT (1981, p. 59-68) chama este fenômeno em que a realidade do mundo é assegurada quando é aparente a todos de "espaço da aparência".

De outro lado, é a banalização promovida pelos Meios de Comunicação que possibilita aos homens comuns projetar suas histórias para toda a humanidade, papel antes reservado apenas aos reis, nobres e heróis. Com a crescente exposição da vida privada pela mídia, não há mais necessidade de feitos heróicos ou 
vivências atípicas, o simples cotidiano e a vida e o pensamento comuns são agora temas para os Meios de Comunicação.

“(...) passa-se da idéia segundo a qual não há democracia sem público a uma outra mais aventureira segunda a qual tudo deve ser colocado em praça pública, sendo a comunicação a garantia da transparência do jogo." (ADGHIRNI, 2002, p. 11)

Além disso, esse trabalho busca retratar as diferenças entre os vários tratamentos oferecidos por cada tipo de Meio de Comunicação e o nível praticado de mediação em cada um deles.

É inegável que esses graus diferem em intensidade e tipo de ação empreendida de mídia para mídia. A própria característica tecnológica influi fortemente nessa diferenciação, imprimindo uma mediação própria da tecnologia usada a cada meio. Um fator comum de mediação, até a entrada no sistema dos meios digitais, era a seleção por parte dos profissionais de cada veículo. Com a internet, várias mudanças vêm sendo empreendidas nesta questão: os blogs ${ }^{11}$, por exemplo, são publicações diretas do público, que são veiculadas dentro de portais e grandes sites de empresas de comunicação ou como sites desenvolvidos pelos próprios usuários.

O papel de mediação dos Meios de Comunicação entre os atores e os processos sociais e sua função no estabelecimento de sentidos vêm sendo apresentados por vários autores. Para abordarmos melhor essa questão, devemos primeiro entender que os Meios de Comunicação, da forma com que os enxergamos hoje, são "(...) estruturas profissionalizadas de distribuição de mensagens" (CORREIA, 2006, p. 2) e essa profissionalização é refletida justamente na “( ...) actividade mediadora que se instaura e consolida

\footnotetext{
${ }^{11}$ Abreviação do termo weblog, de origem americana, é o resultado da união das palavras web e log, significando diário de navegação pela Internet.
} 
como uma dimensão constituinte e estruturante da sociabilidade." (CORREIA, 2006, p. 2)

Essa mediação confere aos Meios de Comunicação a função de construtores/elaboradores da realidade social, configurando uma nova realidade e possibilitando a construção de novos sentidos, de novas redes de significação por parte do público:

“A comunicação mediatizada dos tempos modernos transporta consigo uma forma de vida própria, sintetiza de modo original a constituição da experiência comum e da memória colectiva, com profundas implicações no nosso quotidiano - ao nível das formas de percepção e conhecimento, da prática política, da vivência das relações de poder e da experiência íntima de cada um." (CORRElA, 2006, p. 6-7)

Essa resignificação aparece como resultado do processo de seleção com que se configuram as mensagens e programações das mídias:

“(...) ao escolher o real que vai narrar e ao escolher o modelo narrativo em que o vai exprimir, um jornal (...) reduz a infinitude de realidades $e$ significações a um pequeno conjunto que as representa." (MENDES, 2006, p. 8)

Mas não é só o processo de escolha que determina essa mediação. Inúmeros fatores, entre eles os tecnológicos e os humanos, são também determinantes. No caso dos profissionais dos Meios de Comunicação, podemos aplicar o pensamento de Edgar MORIN (2004, p. 209-13) que sustenta que somente a partir de um repertório variado e do raciocínio não simplificador é que é possível a criação de novas mensagens que dêem conta de traduzir a realidade diante da nova ordem baseada no processo de complexificação do mundo. Trata-se de um trabalho assemelhado aos dos bricoleurs: 
“Os jornalistas afirmam-se, pois, como 'bricoleurs' que apreendem a regularidade em pequenos pedaços, com recurso a saberes práticos, em contradição com os teóricos que surpreendem e se debruçam sobre as grandes regularidades pretendendo, como desejava Platão, impedir esta mesma fragmentação da realidade." (CORREIA, 2006, p. 11, grifos do autor)

Caberá a esses profissionais, de acordo com as características da mídia onde desempenham suas funções, a construção de novos sentidos a partir do estabelecimento de pontes entre atores e processos sociais. No caso específico do jornalismo esta ponte busca manifestar:

“(...) um sentido de pertencimento a uma coletividade (proximidade física ou de identidade cultural) e um sentido de orientação (instrumental), oferecendo recursos para o indivíduo se locomover em ambientes e situações para os quais se exige uma competência avaliativa e procedimental." (FRANCISCATO, 2000, p. 67)

Ou em ALSINA (1996, p. 9):

"Aos jornalistas atribui-se a competência de reconhecer os acontecimentos e temas importantes proporcionando-Ihes um sentido. Esse contrato baseiase em atitudes epistêmicas e coletivas que vão se formando pela implantação do uso social dos meios de comunicação como transmissores de realidade social de importância pública."

O mesmo autor ressalta o papel de mediação desempenhado pelo jornalismo, também com destaque para essa função de reinterpretação e resignificação do mundo:

“(...) o jornalismo é uma prática de mediação social, pois atua como mediador tanto na apresentação dos fatos para uma coletividade quanto na sua interpretação, estabelecendo relações específicas entre atores, temas, situações e contextos diversos na construção do texto noticioso. Além de levar os fatos a conhecimento público, o texto jornalístico estabelece relações de sentidos para os fatos, inserindo-os num tempo e num espaço específicos que lhes dará coerência e unidade." (FRANCISCATO, 2000, p. 68) 
Conforme vimos em MENDES (2006, p. 8), a mediação se dá em dois níveis principais: a seleção e a escolha da linguagem para a narrativa ${ }^{12}$. No primeiro caso, o profissional de comunicação decide quais os temas, as pessoas e as histórias que são mais interessantes para o público consumidor daquele veículo de comunicação. No segundo estágio, opta pelos recursos que facilitarão a compreensão da mensagem pelo seu público, estabelecendo um estilo de narrativa próprio do jornalismo:

“(...) o produtor de informação (...) suprimirá todos os dados susceptíveis de desviar o futuro leitor dos elementos narrativos 'essenciais'. Mas, melhor e mais importante, preferirá os sinônimos com menor número de caracteres, reduzirá o seu vocabulário às significações de base da sua língua materna (...), abolirá do seu texto toda a polissemia, preferirá o ponto final e a vírgula a formas mais complexas de pontuação, produzirá - mesmo artificialmente parágrafos destinados a decompor em curtos 'tempos' a sucessão de movimentos de leitura." (CORREIA, 2006 , p. 12, grifos do autor)

\footnotetext{
${ }^{12}$ A questão da seleção empreendida pelo jornalista/profissional de comunicação que é vinculada aos critérios de noticiabilidade adotados pelo veículo é fundamental para a decisão de trabalharmos com histórias pessoais de anônimos, já que o simples fato de ser uma celebridade criaria um fator de interesse ligado ao personagem e não à história. Ao mesmo tempo, com a adoção cada vez mais freqüente de estratégias de divulgação de sua vida íntima como forma de se manter em evidência, as celebridades contariam com a vantagem de uma assessoria profissional, o que tornaria a comparação com os espaços destinados a anônimos inviável academicamente.
} 


\section{Metodologia}

O objeto deste trabalho são as histórias pessoais vividas pelo público dos meios de comunicação (impressos, eletrônicos e digitais) e que encontram espaços nessas mídias para sua publicação/veiculação a partir de um relato inicial feito pelo próprio protagonista da história/vivência. Esses autores/personagens são, necessariamente, pessoas anônimas, cujas trajetórias muitas vezes não apresentam nenhum destaque em relação às demais vivências humanas, mas que, mesmo assim, buscam nas mídias oportunidades para narrar suas histórias.

Pretende-se, com o desenvolvimento desse estudo, definir qual a tipologia e as características midiáticas em relação aos espaços destinados para essas histórias por cada meio (impressos, eletrônicos ou digitais) e o grau de mediação que as histórias sofrem em cada meio desde o relato original enviado pelo autor até sua publicação/veiculação em cada mídia, analisando as facilidades e dificuldades oferecidas por cada meio de comunicação a este tipo de relato.

Nossos pressupostos são:

I - A busca pela divulgação de sua vida e de seus feitos sempre acompanhou a humanidade. No entanto, o desenvolvimento dos meios de comunicação de massa e seu posicionamento como centro da sociedade contemporânea fizeram aumentar a necessidade humana da divulgação desses relatos e a busca de espaços para isso, bem como transferiram para as mídias o papel de criação desses espaços, tornando-os objeto do desejo humano.

II - A busca humana pela divulgação do seu eu está calcada em três aspectos principais: a confirmação de sua existência (e sua 
reinvenção) a partir dos olhos do outro; a conquista da importância frente aos seus pares; e a sutura da alteridade a partir dos instrumentos oferecidos desde a Modernidade.

III - Os Meios de Comunicação têm espaços e formas diversas para tratar os relatos pessoais. No entanto, todos oferecem algum grau de mediação, sendo que, se analisarmos numa linha histórica de criação, quanto mais antigo o meio, maior o grau de mediação humana e, quanto mais recente, maior o grau de mediação tecnológica. Essa linha histórica indica ainda que a mediação humana tanto será menor quanto a digitalização do meio for maior.

IV - O crescimento dos espaços destinados às histórias pessoais nos meios de comunicação, principalmente a partir das novas tecnologias de comunicação e particularmente nos meios digitais, confere a esses relatos valores de noticiabilidade jornalística.

A partir deles, buscamos com esse trabalho responder à questão elaborada a partir da definição de nosso problema de pesquisa, ou seja, de que forma cada mídia trata as histórias pessoais de seu público (leitor, ouvinte, telespectador ou internauta), qual o grau de mediação em cada um e quais os espaços oferecidos por cada meio.

Sobre isso nossas hipóteses principais são:

I - Os espaços oferecidos para os relatos de histórias pessoais variam de mídia para mídia, no entanto, os critérios de seleção adotados pelos diversos meios de comunicação são praticamente comuns e reproduzem os critérios de noticiabilidade jornalística (interesse e adequação da história ao público do veículo).

II - A expansão das Novas Tecnologias da Comunicação ofereceram a possibilidade do público desenvolver mais livremente 
o papel de autores e, o crescimento deste tipo de experiência influenciou diretamente os demais meios, forçando-os a também criarem novos espaços (e ampliarem os já existentes) para este tipo de comunicação. Essa readequação é parte inerente à configuração do sistema midiático contemporâneo.

Em relação a cada tipo de mídia especificamente, nossas hipóteses são:

a) Mídia Impressa: é das que mais limitaram os espaços destinados aos relatos pessoais do público. Entre as publicações, são as revistas femininas as que sistematicamente têm desenvolvido esses espaços. O grau de mediação humana é muito grande, transformando o relato inicial de forma a adequá-lo à linguagem e ao estilo da publicação.

b) Mídia Eletrônica:

b.1) O Rádio buscou ampliar esses espaços por conta de sua característica interativa e sua baixa complexidade técnica e quanto mais popular é a emissora, maiores são estes espaços. A mediação permanece mesmo quando a participação/relato é ao vivo. No entanto, é quando os relatos são recebidos previamente que essa mediação se dá de maneira mais forte e com mais recursos técnicos (utilização dos elementos constituintes da linguagem radiofônica: a música, a palavra, os efeitos sonoros e o silêncio).

b.2) A Televisão, em função de sua complexidade técnica, limitou esses espaços até muito recentemente. Hoje, com o aumento das participações ao vivo e o crescente interesse por temas comportamentais, esses espaços estão maiores. 
Tal qual o Rádio, quando os relatos não são feitos ao vivo é que a mediação tecnológica mais se destaca.

c) Mídia Digital: os aspectos que marcaram o surgimento da Internet (multidirecionalidade e ausência de centro) determinaram a ampliação das possibilidades de participação do público e a diminuição do papel de mediação dos profissionais de comunicação sobre esses relatos. A mediação, neste caso, é quase totalmente tecnológica e o papel do profissional de comunicação é mais o de um moderador.

O desenvolvimento do tema e a comprovação dessas hipóteses, inicialmente, passam pelo entendimento das motivações e do contexto que leva o público à busca da projeção através da mídia. O papel central das mídias em nossa sociedade, conquistado com as mudanças ocorridas na delimitação das esferas pública e privada, será fator preponderante para a existência e procura por esses espaços.

Assim, essa pesquisa insere-se no campo dos estudos exploratório-descritivos, já que, de um lado, trabalha com um problema que ainda não está embasado por estudos anteriores, enquanto de outro, se propõe a conhecer características bem como estabelecer relações existentes entre variáveis, assim como analisar seus impactos.

Adotaremos ainda a abordagem qualitativa já que buscamos a obtenção de dados descritivos a partir do contato direto com a situação objeto de estudo:

“Nas pesquisas qualitativas, é freqüente que o pesquisador procure entender os fenômenos, segundo a perspectiva dos participantes da situação estudada e, 
a partir daí situe sua interpretação dos fenômenos estudados." (NEVES, 1996, p. 2)

E mais à frente:

“... a modalidade preferida daqueles que procuram saber como e por que certos fenômenos acontecem ou dos que se dedicam a analisar eventos sobre os quais a possibilidade de controle é reduzida ou quando os fenômenos analisados são atuais e só fazem sentido dentro de um contexto específico." (NEVES, 1996, p. 3)

Cabe ressaltar ainda que, segundo FERNANDES; GOMES (2006, p. 117), a análise qualitativa é recomendada em uma pesquisa quando:

"Procura fornecer descrição completa do
fenômeno em toda a sua complexidade; Tenta
descobrir e mostrar suposições que estão por trás das
ações ou eventos; (...) Lida com descrições detalhadas
dos contextos de uma situação; Inicia com questões ou
problemas amplos e procura limitá-los; Tende a lidar
com amostras pequenas e únicas (sem igual); (...)
Depende profundamente de relatar, informar para
demonstrar significância."

No nosso caso, empreenderemos um estudo descritivo sobre essas experiências de histórias pessoais nos meios de comunicação, seu desenvolvimento e os espaços ocupados em cada uma das mídias. O estudo compreenderá ainda as causas que levam o público a buscar esses espaços. ${ }^{13}$

A base para o desenvolvimento desta parte será a pesquisa bibliográfica dos vários autores que vêm trabalhando as questões envolvidas em nossa problemática, combinada à análise documental do material levantado.

Essa associação (pesquisa bibliográfica + análise documental) é fator preponderante para lidarmos com uma temática tão contemporânea e complexa como os meios de

13 Parte II - Falando de Nós. 
comunicação, sua relação e apropriação pelo público, e devidamente justificada nos propósitos da abordagem qualitativa:

"Compreende um conjunto de diferentes técnicas interpretativas que visam a descrever e a decodificar os componentes de um sistema complexo de significados." (NEVES, 1996, p. 2)

Essa complexidade compreende ainda a recuperação histórica do sistema de mídias e seu desenvolvimento social. Busca-se com isso construir um panorama das experiências mais significativas em cada mídia, sem que, com isso, empreenda-se algum tipo de levantamento quantitativo, o que não seria viável em função da extensão e da constante modificação pela qual passa o sistema de mídias ${ }^{14}$.

No entanto, a pesquisa do fenômeno das histórias pessoais contadas através das mídias realizada a partir da bibliografia disponível associada à análise documental permitirá uma adequada compreensão do fenômeno, principalmente no que se refere a destacar exemplos que devem ser analisados mais profundamente.

Neste sentido, a segunda etapa desse trabalho reúne estudos dos casos mais significativos de cada meio de comunicação.

Os estudos de caso são particularmente recomendados para a averiguação de eventos contemporâneos em que os dados são coletados por diversos meios. Isto porque os estudos de caso abrem a possibilidade de empregarmos, em seu desenvolvimento, vários recursos como entrevistas, observação, estudos de campo,

\footnotetext{
${ }^{14}$ A própria dimensão do universo pesquisado inviabiliza a realização deste levantamento histórico mais detalhado como parte de um projeto de doutorado. Sua realização dependeria da dedicação exclusiva à tarefa e, preferencialmente, concentrada em um tipo de meio e por determinado período.
} 
análise documental etc., podendo ser escolhidos de acordo com a tarefa a ser cumprida.

Segundo Cláudia DIAS (2006, p. 2), estudos de caso são a oportunidade para a análise de um problema em profundidade, por um período de tempo limitado, e são úteis:

"quando a compreensão dos processos sociais em seu contexto organizacional ou ambiental é importante para a pesquisa; quando a intenção de pesquisa é explorar casos atípicos ou extremos para melhor compreender os processos típicos; em pesquisas comparativas em que seja essencial compreender os comportamentos e as concepções das pessoas em diferentes localidades ou organizações."

YIN (Cf. 2005) destaca que os estudos de caso são estratégias de pesquisa adequadas quando se busca examinar um fenômeno contemporâneo dentro de seu contexto, o que é exatamente o caso desta pesquisa.

Ele ainda revela que os estudos de caso são as melhores estratégias quando o "como" e/ou o "por que" são as perguntas centrais do pesquisador.

No caso específico desse trabalho, após a descrição detalhada das mídias e seus espaços destinados às histórias pessoais, serão selecionados casos em cada uma delas que se destaquem dos demais pela maior relevância dessa experiência. Note-se que não pretendemos nos debruçar sobre os casos que melhor representam a média ${ }^{15}$ das experiências realizadas em cada meio de comunicação, e sim buscar os exemplos que mais exploram as potencialidades de cada mídia e, por isso, se destacam das demais. Nosso objetivo não é partir do individual para representar o todo, mas sim determinar quais são as

\footnotetext{
${ }^{15}$ Inclusive porque diante do tamanho do universo pesquisado, seria impossível estabelecer essa média.
} 
potencialidades de cada meio a partir de seus exemplos mais diferenciados.

Para isto, devemos analisar inicialmente a questão da seleção nos meios de comunicação, tal qual apontada por LUHMANN (Cf. 1996), em três diferentes etapas: a seleção da informação ( $1 \underline{\text { a }}$ etapa); a seleção do ato de comunicar ( $2 \underline{a}$ etapa); e a seleção que se realiza no ato de entender/não entender a informação e o ato de comunicar ( 3 a etapa).

Neste caso, a mediação tecnológica proporcionada por cada Meio de Comunicação, de acordo com suas características próprias faz parte da segunda etapa. Essa vertente é igualmente importante neste processo de mediação e, no caso desta pesquisa, terá efeitos determinantes sobre o tipo de espaço fornecido e as formas de narrativas/reconstrução das histórias pessoais publicadas/veiculadas.

Neste sentido, inicialmente, podemos agrupar os Meios de Comunicação enfocados neste trabalho em três grandes grupos conforme sua vertente tecnológica: mídia impressa compreendendo jornais e revistas; eletrônica - reunindo rádio e televisão; e digital - enfocando a web e seus produtos comunicacionais.

A análise do tipo de mediação que a narrativa inicial (do próprio autor) da história pessoal sofreu até sua divulgação pelo meio de comunicação, será realizada nestes três grupos.

Para a escolha dos casos, inicialmente foi feito um levantamento sobre a dimensão do universo pesquisado: os veículos de comunicação que compõem os diversos meios e suas divisões - impresso (jornais e revistas), eletrônico (rádio e televisão) e digital (web - comunidades virtuais e blogs). Mais que apontar um puro dado quantitativo, o levantamento teve como 
objetivo apontar as dimensões do sistema midiático e, a partir disso, estabelecer níveis de cortes que nos possibilitassem o aprofundamento necessário para a escolha dos casos a serem estudados.

No caso de mídia impressa foi feito inicialmente uma pesquisa ${ }^{16}$ junto à ANJ - Associação Nacional de Jornais e ANER Associação Nacional de Editores de Revistas, para determinar quantos são os veículos associados.

No caso da ANJ, havia, na época da pesquisa ${ }^{17}, 144$ jornais filiados em todo o país e no caso da ANER, 70 Editores que eram responsáveis por 707 títulos.

Diante desse número, decidimos acompanhar os vinte veículos de maior circulação segundo o IVC - Instituto de Verificação de Circulação. No caso de jornais, são cinco os que compõem a lista: Extra (Circulação média diária no 1ํ semestre de 2007: 315.964), Folha de S. Paulo (299.761), O Globo (275.141), O Estado de S. Paulo (238.122) e Meia Hora $(197.716)^{18}$.

Desses cinco, o Meia Hora, do grupo carioca "O Dia", completando em 2007 dois anos de existência, não foi incluído no acompanhamento por ter formato (tablóide), padrão de número de páginas (apenas de 32 a 44 páginas) e circulação (apenas de segunda a sexta-feira) diferentes dos demais.

Os outros quatro jornais foram acompanhados durante duas semanas para que fossem identificadas histórias pessoais encaminhadas pelo público e publicadas como uma narrativa do próprio autor.

\footnotetext{
${ }^{16}$ A pesquisa foi feita através dos sites das duas entidades. ANJ www.anj.org.br e ANER - www.aner.org.br

${ }^{17}$ Os dados indicados na Metodologia foram levantados nos meses de Junho, Julho, Agosto e Setembro de 2007.

${ }_{18}$ Dados nacionais do IVC - Instituto de Verificação de Circulação.
} 
Notou-se, nesta primeira avaliação do meio, que o espaço destinado a este tipo de narrativa são as seções de cartas. No entanto, mesmo lá, são raros os depoimentos pessoais, prevalecendo as opiniões sobre questões locais, nacionais ou internacionais em geral tratadas pelo veículo em alguma matéria, reportagem ou artigo.

As cartas do público aparecem também nas seções específicas para tratar de Direito de Consumo, com narrativas de problemas encontrados com a aquisição de produtos e serviços. Estas seções se caracterizam pela publicação da reclamação do consumidor, a resposta da empresa e o posicionamento final do reclamante a respeito das providências/explicações da empresa.

Não há um espaço semelhante para que esse mesmo público compartilhe suas experiências de vida e/ou mundo íntimo com os demais leitores.

Mesmo nos suplementos publicados semanalmente nos jornais, esses relatos, em geral, só aparecem dentro de reportagens sobre temáticas em que eles se encaixam.

Assim, diante do fato de não haver um espaço delimitado para esse tipo de material que é publicado apenas eventualmente, optamos por concentrar os dois casos em revistas que, em mídia impressa, oferecem mais possibilidades de análise.

$\mathrm{Na}$ delimitação do universo pesquisado, no caso das revistas, além de um número ainda maior de publicações, tivemos que avaliar os vários segmentos em que se divide o grupo inicial.

Segundo dados do IVC, dos vinte veículos de maior circulação (dados nacionais) ${ }^{19}$, quinze são revistas: Veja (1.100.976); Época (424.683); Nova Escola (410.560); Cláudia

${ }^{19}$ Dados do primeiro semestre de 2007. 
(395.078); Seleções do Reader's Digest (393.078); Veja São Paulo (349.259); Isto É (346.704); Superinteressante (335.231); Caras (299.349); Nova (225.938); Manequim (203.852); Playboy (192.647); Monet (188.109); Boa Forma (185.888); e Marie Claire (182.030).

Das quinze, uma é encartada em outra publicação (Veja São Paulo), uma é vinculada a uma operadora de TV por assinatura (MONET), três são de informações gerais (Veja, Época e Isto É), uma é masculina (Playboy), uma é de ciência (Superinteressante), uma de celebridades (Caras), uma sobre Educação (Nova Escola), uma de variedades (Seleções do Reader's Digest) e cinco femininas (Cláudia, Nova, Manequim - voltada a corte e costura, Boa Forma - revista de beleza e Marie Claire).

Dos títulos analisados, apresentavam relatos diretos do público sobre suas experiências de vida de maneira sistemática apenas as revistas femininas.

Dentre as revistas femininas pesquisadas, a que mais chamou atenção foi a Marie Claire, da Editora Globo, com sua seção "Eu, leitora". Trata-se de uma revista mensal, voltada ao público feminino adulto que mantém este tipo de narrativa desde seu lançamento.

O segundo caso a ser analisado não foi escolhido entre as revistas de maior circulação, mas o pioneirismo de sua proposta justifica a inclusão. A revista Sou + Eu! foi lançada em novembro de 2006, quando o projeto desta pesquisa já estava adiantado. Porém, diante de sua proposta de só trabalhar com relatos das próprias leitoras, ela representa, atualmente, o espaço máximo para as narrativas que são o objeto desta tese. 
A revista Sou + Eu!, inclusive, remunera as leitoras pelas histórias enviadas e publicadas. O valor depende do tamanho da matéria e do destaque que ela terá na edição.

Trata-se de uma revista semanal, da Editora Abril que traz, em suas cerca de 40 páginas, histórias enviadas pelas leitoras que participam também com fotos, dicas e perguntas. Em função do número de histórias em cada edição, optamos, inicialmente por enfocar apenas as histórias principais de cada número que recebem o maior destaque na capa das edições e que são publicadas em três páginas. No entanto, na entrevista com a editora da revista, fomos informados que esta matéria é a única que é definida pela redação e os jornalistas buscam os personagens. Assim, optamos por trabalhar com matérias (uma por edição) que tenham recebido chamada na capa e que tenham o espaço maior (depois da principal).

Com isso, em mídia impressa, trabalharemos com o estudo aprofundado das seções "Eu, leitora", de Marie Claire e uma matéria de destaque de Sou + Eu!.

Em mídia eletrônica, a pesquisa foi dividida em rádio e televisão, buscando a identificação de um caso para estudo em cada tipo de mídia.

Em rádio, o corte inicial foi feito em relação à localização geográfica das emissoras. A adoção desse critério metodológico é justificada em função do rádio ser uma mídia local, voltada cada vez mais às comunidades onde está inserido geograficamente. Ao mesmo tempo, o corte geográfico na mídia rádio, auxilia o estabelecimento de uma linha comum entre os casos estudados em todos os meios, já que estariam todos acessíveis ao mesmo público: os moradores de São Paulo, a maior metrópole brasileira. 
Embora as demais mídias pesquisadas (impressa, TV dentro de eletrônica - e digital) tenham alcance nacional e/ou global, o rádio ( $\mathrm{e}$, em particular, as $\mathrm{FMs}^{20}$ ) tem como uma de suas características intrínsecas a limitação do alcance condicionamento vencido pelas transmissões de rádio pela internet $^{21}$.

Definido para o meio radiofônico este nível de corte, podemos identificar 39 emissoras de rádio $\mathrm{FM}$ e 27 emissoras $\mathrm{AM}^{22}$ em funcionamento na Grande São Paulo ${ }^{23}$. Do total de emissoras, identificamos as cinco FMs e as cinco AMs de maior audiência segundo o Ibope ${ }^{24}$, que são:

FMs = Nativa $(95,3 \mathrm{MHz})$, Tupi $(104,1 \mathrm{MHz})$, Transcontinental (104,7 MHz), Mix (106,3 MHz) e Band $(96,1$ $\mathrm{MHz}$;

$$
\text { AMs = Globo }(1100 \mathrm{kHz}) \text {, Capital }(1040 \mathrm{kHz}) \text {, }
$$
Bandeirantes ( 840 kHz), J ovem Pan (620 kHz) e Tupi (1150 kHz).

Essas emissoras foram acompanhadas de duas maneiras: primeiro através de seus sites onde foram identificados programas que poderiam trazer relatos de histórias pessoais do próprio público; depois, os programas identificados foram acompanhados para a confirmação da existência das histórias e a escolha do caso a ser estudado.

Nossa escolha recaiu em "Que saudade de você", do programa "Eli Correa", da Rádio Capital AM. Trata-se de um dos mais antigos e tradicionais do rádio paulistano, tendo migrado de

\footnotetext{
${ }^{20}$ Freqüência Modulada.

${ }^{21}$ Sobre isto ver TRIGO-DE-SOUZA, Ligia Maria. Rádios@Internet - O desafio do áudio na rede.

${ }^{22}$ Amplitude Modulada.

${ }^{23}$ Essas emissoras constam do relatório de audiência da Grande São Paulo elaborado pelo I bope.

${ }^{24}$ Dados do trimestre Maio/J unho/J ulho.
} 
emissora para emissora com seu apresentador sem, no entanto, sair do ar. Foi objeto de Dissertação de $M^{2} \operatorname{strado}^{25}$ em que foi apresentado como modelo de construção do que foi denominado uma partitura sonora. Atualmente é veiculado de segunda a sexta, às $14 \mathrm{~h}$, com a reprise de um dos casos apresentados na semana aos sábados.

Para televisão, optamos por escolher as redes e emissoras de TV aberta, que podem ser sintonizadas por toda a população. A exclusão das emissoras distribuídas por pacotes de assinatura teve três motivos principais: o número muito grande de emissoras, que inviabilizaria a pesquisa; as diferenças entre distribuidoras (e dentro delas a diferença entre os pacotes oferecidos) que reduziria o público que tem acesso a eles e, por fim, o número de canais com programações estrangeiras (a maioria das emissoras por assinatura) que poderiam criar uma distorção para a análise dos casos escolhidos.

A partir dessa delimitação, passamos a trabalhar com o universo de 11 emissoras de TV com recepção em São Paulo ${ }^{26}$. Destas, foram selecionadas as quatro com maior audiência no painel nacional: Rede Globo; SBT - Sistema Brasileiro de Televisão; Rede Record e Rede Bandeirantes ${ }^{27}$.

As quatro emissoras foram acompanhadas inicialmente pelos seus sites para a identificação dos programas com relatos representativos do universo desta pesquisa. As veiculações foram acompanhadas até a escolha do programa "Casos de Família", do SBT. Apresentado pela jornalista Regina Volpato, o programa traz

\footnotetext{
${ }^{25}$ Ver: VALLE, Luciane Ribeiro do. Que saudade de você: a construção de uma dramaturgia radiofônica.

${ }^{26}$ Segundo dados do Plano Básico de Radiodifusão, do Ministério das

Comunicações. Site: www.mc.gov.br

${ }^{27}$ Segundo dados do I bope de Junho de 2007.
} 
cidadãos anônimos para discutirem com a platéia e especialistas questões de sua vida privada.

Em mídia digital, a principal dificuldade encontrada nos outros tipos de meios (a necessidade de refinamento em função do tamanho do universo a ser pesquisado) é elevada à enésima potência (em função da natureza global da mídia) e agravada pela falta de um centro que permita o registro e/ou identificação de todas as experiências que são produzidas.

Aliado a isto está o fato de que a web (face multimídia para distribuição de conteúdos da Internet) não dispõe exatamente de veículos de mídia tal como os demais meios. Ao tentarmos estabelecer classificações, trabalhamos muito mais com tipos de estruturação de conteúdo que com veículos para sua transmissão ${ }^{28}$.

E, apesar de termos empresas estruturadas para a distribuição de conteúdo (em particular os portais que poderiam, a grosso modo, ser vistos como veículos de distribuição digital de conteúdos) temos com a internet uma potencialidade maior para a exploração de narrativas/conteúdos não mediados por estruturas tradicionais de comunicação (como as redações). Não é necessário para veicular conteúdo pela internet, por exemplo, abrir um jornal, contratar gráfica e distribuidora, ou conseguir uma licença do Ministério das Comunicações para operar uma rádio. Um simples computador doméstico, o acesso à rede e o espaço em um servidor são suficientes.

\footnotetext{
${ }^{28}$ Classicamente, definimos meios de comunicação como formas de distribuição de mensagens enquanto os veículos são as "empresas" encarregadas da transmissão. As questões relativas à distribuição de mensagens estariam ligadas ao como no caso dos meios e a por quem no caso dos veículos. Assim, em nossos casos já escolhidos, temos: as revistas Marie Claire e Sou + Eu como veículos do meio impresso; a Rádio Capital como veículo do meio radiofônico; e o SBT como veículo do meio televisivo.
} 
Assim, nossa primeira delimitação para definição dos casos estudados não foi em termos de veículos e sim do tipo de produção/ambiente que favorecesse as narrativas que buscamos estudar. Nossa escolha se voltou, portanto, para dois tipos de experiências que vêm se destacando na rede neste tipo de narrativa: as comunidades virtuais e os blogs.

Comunidade virtual é, segundo a Wikipédia, (COMUNIDADE VIRTUAL, 2007):

"uma comunidade que estabelece relações num espaço virtual, através de meios de comunicação a distância. Se caracteriza pela aglutinação de um grupo de indivíduos com interesses comuns que trocam experiências e informações no ambiente virtual.

Um dos principais fatores que potencializam a criação de comunidades virtuais é a dispersão geográfica dos membros. O uso das Tecnologias de Informação e Comunicação - TICs minimizam as dificuldades relacionadas a tempo e espaço, promovendo o compartilhamento de informações e a criação de conhecimento coletivo."

Já blog, também segundo a Wikipédia (BLOG, 2007, grifos do site), tem a seguinte definição:

“Um weblog, blog ou blogue é uma página da Web cujas atualizações (chamadas posts) são organizadas cronologicamente de forma inversa (como um diário). Estes posts podem ou não pertencer ao mesmo gênero de escrita, referir-se ao mesmo assunto ou ter sido escritos pela mesma pessoa.

O weblog conta com algumas ferramentas para classificar informações técnicas a seu respeito, todas elas são disponibilizadas na internet por servidores e/ou usuários comuns. As ferramentas abrangem: registro de informações relativas a um site ou domínio da internet quanto ao número de acessos, páginas visitadas, tempo gasto, de qual site ou página o visitante veio, para onde vai do site ou página atual e uma série de outras informações.

Os sistemas de criação e edição de blogs são muito atrativos pelas facilidades que oferecem, pois dispensam o conhecimento de HTML, o que atrai pessoas a criá-los. 
A Deutsche Welle premia a cada ano os melhores weblogs internacionais em onze categorias no evento The Bobs - Best of Blogs."

Feita essa escolha, passamos ao mapeamento das várias publicações de cada um dos tipos, o que representa um novo fator de dificuldade porque, como vimos, é da natureza da internet não possuir um centro para onde as experiências existentes possam convergir. O caminho mais recorrido, nestes casos, é o dos sites de busca que através de mecanismos de navegação remota identificam as URLs e seus conteúdos disponibilizados. No entanto, o resultado dessas buscas nem sempre é preciso, trazendo ao usuário milhares de referências que não são exatamente o que ele está buscando.

Em nossa pesquisa, optamos pela utilização do Google ${ }^{29}$, o mais famoso dos sites de busca. No entanto, os resultados não foram animadores. Ao digitarmos "comunidade virtual" na caixa de procura, o site devolveu com 2.540.000 (dois milhões quinhentos e quarenta mil) resultados para a consulta. Muitos desses resultados não se referiam a um site de determinada comunidade virtual e sim a informações sobre o tema (artigos, reportagens, enciclopédias etc). Restringindo a pesquisa a sites do Brasil, o número, embora menor, continuou a inviabilizar o refinamento de dados: 2.120 .000 (dois milhões cento e vinte mil resultados).

Para a escolha dos casos a serem estudados foi necessário então o cruzamento de variadas fontes de informação sobre o tema, em particular sites e publicações especializadas em internet. O levantamento reuniu, portanto, as experiências que foram objeto de matérias/notícias sobre blogs e comunidades

${ }^{29}<$ www.google.com. br> A pesquisa foi feita em junho de 2007. 
virtuais. Os veículos escolhidos para o levantamento foram: Webinsider $^{30}$, Info Online ${ }^{31}$, IDG Now! ${ }^{32}$ e PC World ${ }^{33}$. Todas estas fornecem possibilidade de pesquisa em seus arquivos, o que dispensou a necessidade de se estabelecer um período para a pesquisa.

No caso dos blogs, foi considerado também os destaques do Blogger Brasil ${ }^{34}$ e do $\mathrm{UOL}^{35}$, as indicações do The Bobs $^{36}$, principal premiação dos blogs do mundo todo, edição de 2007 e o ranking elaborado pelo BlogBlogs ${ }^{37}$.

Com isso, chegamos aos cases de "Viva SP", entre as comunidades virtuais e "Puzzle Diário", de Lucia Faria, em blogs.

O "Viva SP" foi criado por ocasião do aniversário de 450 da cidade de São Paulo. Foi ao ar em 2003 (com a URL www.sp450.com.br) e continua ainda hoje (www.vivasp.com). Reúne depoimentos/relatos enviados pelo público sobre a cidade e sobre a relação dos autores com ela, suas memórias etc. O projeto chegou a receber 200 relatos/mês.

No caso dos blogs, a escolha recaiu em "Puzzle Diário"38, de Lucia Faria. A blogueira é famosa no meio (está nas listas dos mais influentes na blogosfera brasileira tanto do Technorati quanto do BlogBlogs) por outro blog seu, o "Ladybug Brasil", de caráter menos intimista. O "Puzzle" foi seu primeiro blog (ao lado de "Jardim dos Narcisos" - ambos criados em 2003) e hoje, além de manter os três individuais, participa também de

\footnotetext{
${ }^{30}$ www. webinsider.uol.com.br

${ }^{31}$ http://info.abril.com.br/

32 http://idgnow.uol.com.br/

33 http: //pcworld.uol.com.br/

${ }^{34}$ http://blogger.globo.com/index.jsp

35 http://blog.uol.com.br/

${ }^{36}$ http://www.thebobs.com/

37 http://www. blogblogs.com.br/blogs/top_ranking/ 1

${ }^{38}$ http://puzzlediario. blogspot.com/
} 
quatro blogs coletivos ("Goitacá", “Desabafo de Mãe”, "Faça a sua parte", e "Nossa Opinião").

Definidos os casos a serem objeto de estudo aprofundado, foi necessário definir qual a abordagem que seria adotada para a análise.

Para dar uniformidade a esta análise, optamos por trabalhar com o mesmo número de edições dos casos escolhidos. Este critério (número de edições) se mostrou melhor que a adoção de intervalo de tempo em função de a periodicidade de cada veículo/caso escolhido ser muito diferente.

Optamos por trabalhar com cinco edições de cada caso , número que nos fornecerá condições suficientes para o estudo aprofundado de cada um.

A partir do levantamento do material para análise, procederemos a entrevistas com os responsáveis (produtores, editores ou autores), abordando o histórico do produto; os critérios de noticiabilidade adotados; a relação da quantidade de material recebido e do espaço destinado à publicação; e o processo por que passa o relato inicial até sua publicação; além de questões específicas relacionadas a cada caso.

Nosso objetivo é conhecer:

- a proposta do programa/quadro/seção/site;

- a resposta do público (quer através do envio de suas histórias, quer no comentário às histórias publicadas);

- o tratamento que as histórias recebem por parte dos editores/profissionais responsáveis. Neste último caso, buscamos respostas a: quais os critérios adotados na seleção dos casos; se houve ou não adequação da linguagem; se foram ou não utilizados recursos adicionais para representar a história original (sons, 
imagens, dramatização etc); se as adequações realizadas (quando existiram) foram resultados da mediação humana ou tecnológica; se os relatos correspondem aos critérios de noticiabilidade informados pelo veículo. No caso específico dos blogs (quando a edição/seleção é feita pelo próprio autor), buscamos compreender como se dá o processo de seleção (critérios) do que publicar ou não; quais as limitações/condicionantes impingidas pelo meio; quais os espaços destinados ao público; de que forma a participação do público influencia nos novos posts.

No caso de revistas, rádio, televisão e comunidade virtual, sempre que possível ${ }^{39}$, serão juntados ao material levantado os relatos iniciais enviados pelo público. A comparação dos dois materiais poderá comprovar as respostas dos produtores a respeito das alterações/adequações sofridas pelos relatos, bem como a classificação de em quanto essas modificações são resultado da ação tecnológica ou da ação humana.

O material publicado ou veiculado será objeto de exame, através de técnicas de análise de conteúdo, com o objetivo de avaliar a correspondência ou não aos critérios de noticiabilidade apresentados pelos produtores/editores/autores e também para verificação de quais elementos de linguagem específica do meio a que pertence estão presentes na narrativa.

Ao final, poderemos classificar o tipo de mediação a que foi submetido o relato original, observando os seguintes critérios:

a) Seleção - se existe, é feita pelo próprio autor ou pelo veículo/programa/quadro;

b) Escolha da linguagem - é respeitado o relato feito pelo próprio autor ou o veículo/programa/quadro o reescreve;

\footnotetext{
${ }^{39}$ No caso de os veículos guardarem esses relatos e puderem/concordarem em disponibilizar para a pesquisa.
} 
c) Incorporação de elementos da linguagem específica do meio (ilustrações, sonoplastia etc)- se são utilizados e se a decisão é do próprio autor ou do veículo/programa/quadro;

d) Adequação às características do meio (tamanho/ tempo)

- a decisão é do autor ou do veículo/programa/quadro. 


\section{I. FALANDO DE NÓS}

"Porque, afinal, do que andamos tratando é da dignidade de ser, algo, recordado." (Renato J anine Ribeiro. Memórias de si, ou...) 


\section{Contextualização e Histórico}

Narrar a experiência da aventura humana não é novidade. Desde o início da história da humanidade, antes mesmo da invenção da escrita, os feitos, glórias e infortúnios da vida humana eram contados de geração para geração. E ao registrarmos essas histórias, de certa forma, perpetuamos seus atores. Mais que isso, concedemos ao homem o papel central do universo em que vivemos. Contar a história do nosso mundo a partir da história e dos feitos dos homens é a forma de colocarmos nossa natureza no centro do universo. É também a maneira de reforçarmos nossa própria cultura como um "campo de análise conceptualmente relevante, pertinente e teoricamente fundamentado" (WOLF, 1999, p. 108) ${ }^{40}$.

No início, as narrativas eram centradas nos feitos heróicos e na vida dos reis, dos sábios, enfim, das personalidades de cada sociedade. No entanto, desde muito cedo também o homem comum buscou inserir seu próprio relato (e, portanto, sua própria existência) na história do mundo.

Segundo BAKHTIN (1999, p. 4-5, grifos do autor), são os rituais da cultura popular cômica que inauguram a celebração desse novo homem, o homem comum:

\footnotetext{
"Ofereciam uma visão do mundo, do homem e das relações humanas totalmente diferente, deliberadamente não-oficial, exterior à Igreja e ao Estado; pareciam ter construído, ao lado do mundo oficial, um segundo mundo e uma segunda vida aos quais os homens da Idade Média pertenciam em maior ou menor proporção, e nos quais eles viviam em ocasiões determinadas."
}

${ }^{40} \mathrm{O}$ texto em questão refere-se à Cultura dentro dos Estudos Culturais. 
Ao retratar o Carnaval, BAKHTIN (1999, p. 6) nos mostra como essas formas de representação já na Idade Média pertencem à esfera particular da vida cotidiana.

No entanto, apesar de termos claro que os períodos não são estanques entre si, podemos considerar uma divisão indicativa de eras a fim de identificar os fatores que mais as caracterizaram. $E$, neste sentido, indicar como a forma e a importância mudaram de era para era: se na Idade Média, muito da história do homem estava centrada em sua ligação com Deus, na Modernidade atinge seu ápice com as luzes do Iluminismo e o homem passa a justificar o andamento da história, ainda que as raízes da valorização do homem comum já apareçam no Medievalismo.

O novo papel da história humana passa a ser fortemente ligado a dois fatores principais: o individualismo como um dos pilares do projeto emancipatório iluminista e as mudanças estruturais nas esferas pública e privada trazendo novos conceitos relativos à privacidade, individualidade e intimidade.

No que se refere à Modernidade, suas próprias características reforçam esse pensamento. Se Deus foi o centro da estruturação das sociedades medievais, a era Moderna desloca o homem para este papel central. Pelo projeto Moderno, individualismo, racionalismo e universalismo seriam capazes de levar o homem à emancipação.

Essas características terão origem no colapso do Medievalismo e sua ordem social, econômica e religiosa. Neste último campo, o próprio surgimento do Protestantismo reforça a questão da existência pessoal ao propor a relação direta e individual de cada ser humano com Deus. (WILLIAMS, 1976, p. 28) 
No entanto, o Iluminismo buscava livrar o homem dos entraves e limitações do meio e da crendice, em campos mais abrangentes que somente o da religião. Essa libertação seria possível a partir da lógica e do conhecimento proporcionados pela ciência e teria como base a razão. A idéia do desejável e inevitável progresso, da emancipação universal através da ciência iria influenciar em outro ponto da identidade do nosso sujeito Iluminista: a quebra da tradição. Seu destino não estava mais traçado previamente à sua existência e cabia a ele definir sua posição na sociedade.

“...emancipar significava racionalizar, tanto no sentido negativo de libertar a consciência humana tutelada pelo mito, como no sentido positivo de usar a ciência para tornar mais eficazes as instituições econômicas, sociais e políticas. (...) Emancipar implicava individualizar, desprender o homem das malhas do todo social. (...) Emancipar equivalia a universalizar, a dissolver os particularismos locais, removendo assim as causas dos conflitos entre os homens." (ROUANET, 1993, p. 97)

Essa mudança de posicionamento é fundamental para o entendimento de como o mundo pode ser visto e interpretado a partir das histórias dos homens. O homem será emancipado a partir da sua individualização, compreendida como seu desprendimento das malhas do todo social.

"Se os mitos contam como uma realidade passou a existir, como cada coisa foi criada, ao espelhar suas ações neles, o homem passa a assumir uma atitude igualmente criadora, passa a ser digno da criação, posto que, dela, co-criador. Por isso se pode dizer que, no mito, o homem organiza o mundo - o que é bastante diferente de afirmar que uma organização do mundo está representada no mito. A representação vai aparecer só mais tarde na história do pensamento, com a racionalização." (COSTA, Ana Beatriz, 2004, p. 2)

Para CALLIGARIS (1998, p. 3): 
“Uma descrição rápida mas não grosseira da modernidade ocidental poderia expressá-la como uma cultura na qual se espera que do sujeito venha a organização do mundo (e não do mundo a organização do sujeito)."

Assim, mesmo para o homem comum, a individualidade passa a ser importante e expressá-la publicamente é parte do contexto em que vive.

Esse contexto é marcado pelas modificações ocorridas nos campos das esferas pública e privada, fenômeno que também pode ser identificado fortemente com a Modernidade, embora os conceitos de público e privado tenham vindo de muito antes na história.

HABERMAS (1984, p. 14) ressalta que a expressão "público" pode designar eventos acessíveis a qualquer um (em contraposição às realizações de sociedades fechadas) ao mesmo tempo em que também é sinônimo para Instituições do Estado; denomina a expressão ou fama de determinada pessoa; ou ainda identifica o grupo de recepção de uma obra de arte ou produto comunicacional. No entanto, é no sentido de identificar a esfera da opinião de determinado grupo ou sociedade que o conceito é desenvolvido pelo autor e que nos interessa neste trabalho.

De toda forma, em todos esses significados permanece a raiz de algo que é comum a várias pessoas ou a um conjunto delas (grupo étnico, comunidade etc): o evento é público porque é aberto às pessoas em geral; o Estado é o poder público porque gerencia os negócios comuns aos cidadãos; tal indivíduo tem renome público porque é conhecido por várias pessoas etc. E é nesta definição que surgirá sua oposição ao privado.

O privado está relacionado ao mundo particular das pessoas. Na economia, está vinculado aos negócios que não são 
geridos diretamente pelo Estado (muito embora sofram a influência de sua atuação). Na vida cotidiana, a privacidade é relacionada aos aspectos que podemos preservar da exposição pública e àqueles pertencentes à vida familiar.

A origem do conceito contraposto entre público e privado está na cultura helênica: a Ágora grega, ou seja, a praça onde os cidadãos se reuniam para debater as questões relativas ao governo e à cidade em oposição ao oikos - particular a cada indivíduo. E se, na Idade Média o conceito reaparece (embora sem a contraposição existente no modelo clássico antigo), é só no surgimento do Estado Moderno que ele vai se firmar com o sentido específico de uma esfera pública burguesa. (HABERMAS, 1984, p. $15-17)^{41}$

No entanto, embora se apresentem como opostos, público e privado nunca caminharam totalmente isolados. Já na sociedade grega, a participação na vida pública (bios politikos) através do debate das questões relativas ao governo e à cidade (público) dependia da posição dos cidadãos como senhores da casa, ou seja, do seu status na vida privada.

Também na religião é possível a percepção das relações que se estabelecem entre as duas esferas: se a Igreja é uma instituição pública, a crença, que leva os indivíduos a optarem por seguir determinada religião, pertence claramente à esfera privada. ${ }^{42}$ Ao seguirem a religião são orientados em sua fé (privada) pela Instituição religiosa (pública).

A interpenetração pode ser observada também na configuração da esfera pública como opinião pública (imbuída de

\footnotetext{
${ }^{41} \mathrm{O}$ autor lembra que o sentido dado pela burguesia à esfera pública é a de trazer embutida em si a crítica ao Estado.

42 HABERMAS (1984, p. 24) afirma que a liberdade de crença é, historicamente, a primeira esfera da autonomia privada.
} 
uma crítica ao estado): em torno do século XVIII, as atividades econômicas restritas à economia doméstica rompem o limiar do privado e passam a ser geridas à luz do público. Diz HABERMAS (1984, p. 33):

"A atividade econômica privatizada precisa orientar-se por um intercâmbio mercantil mais amplo, induzido e controlado publicamente; as condições econômicas, sob as quais elas ocorrem agora, estão fora dos limites da própria casa; são, pela primeira vez, de interesse geral."

Neste cenário de interpenetração das esferas, a expansão dos meios de comunicação teve um papel crucial. É através do desenvolvimento rápido da imprensa e sua vinculação com a economia e com a circulação de mercadorias que público e privado mais se confundem. Afinal, ao falarmos dos veículos de imprensa falamos de empresas privadas (hoje grandes conglomerados) que passam a desempenhar um papel público (distribuição de informações) que, por sua vez, tem um objetivo privado: auxiliar na tomada de decisões nos negócios particulares.

$\mathrm{Na}$ verdade, as relações entre espaços públicos e privados não são estáticas. Antes disto, são determinadas pelas características de cada sociedade e acompanham as transformações sofridas por elas.

Como exemplo, podemos acompanhar a evolução arquitetônica das casas e dos espaços dentro delas destinados a atividades públicas ou privadas.

Num primeiro momento, a consolidação da sociedade burguesa trouxe a separação entre os espaços de convivência mais pública e os privados: pátios encolheram e foram tirados do meio das casas para suas áreas externas; os espaçosos vestíbulos diminuíram e até desapareceram; as múltiplas funções dos salões foram divididas entre vários espaços. 
Mas é preciso lembrar que mesmo o espaço privado traz subcategorias, como o íntimo. HABERMAS (1984, p. 73) diz:

"À esfera do mercado chamamos de esfera privada; à esfera da família, como cerne da esfera privada, chamamos de esfera íntima. Esta crê ser independente daquela, quando na verdade está profundamente envolvida nas necessidades do mercado."

E, mais à frente, foi o crescimento da importância do espaço íntimo dentro do privado que levou ao aumento dos espaços individuais (como quartos e banheiros) e à diminuição dos espaços de uso mais coletivo, como a sala de estar ou de visitas.

Mesmo os momentos de convivência pública passaram, em grande parte, a serem vividos em espaços privados: shopping centers, estádios, casas de espetáculos etc. superam em número as opções públicas de lazer.

Não há muita diferença no que vem ocorrendo com os espaços dentro dos meios de comunicação. Assistimos no desenvolvimento de nossa cultura de mídia, ao crescimento de materiais sobre histórias privadas em detrimento das questões públicas. Com origem no entretenimento e, posteriormente, afetando também o jornalismo, o crescimento do espaço para a vida privada de personagens e celebridades tem se destacado tanto no que se refere a número de veículos de comunicação voltados para esse fim, como nos espaços destinados dentro dos veículos gerais.

Mas se na organização espacial o privado se expandiu em relação ao público (e, dentro do privado, o íntimo ganhou espaço), na perspectiva do tempo, a questão tomou outro rumo.

Em primeiro lugar devemos observar que, na sociedade contemporânea, o crescimento do tempo passado no trabalho e 
nos deslocamentos pela cidade, além das atividades sociais, fez encolher o tempo gasto em família, na esfera mais íntima.

"A vida torna-se uma sucessão dinâmica de acontecimentos, pelos quais se passa de forma ligeira. As pessoas como que colecionam diversas atividades e realizam-nas em tempo recorde, num tipo de compulsão de fazer sempre mais, pelo prazer do fazer. É o princípio do movimento pelo movimento." (MARCONDES FILHO, 2004, p. 53)

Vale lembrar que embora o mundo do trabalho faça parte da esfera privada da vida das pessoas, a separação entre seus espaços com o de convivência familiar (a casa) deu a ele uma significação menos pessoal.

Os ambientes do mundo do trabalho, antes vinculados às próprias residências, são cada vez mais dissociados da vida íntima de cada um. Estruturados de acordo com as modernas técnicas de reengenharia e programas de qualidade, esses ambientes distanciam-se muito da possibilidade de vida em família. A própria concepção do trabalho como um ofício, desempenhado integralmente pelo profissional, perdeu força diante das linhas de produção onde cada um tem um limite de atuação e raramente dispõe da percepção do processo como um todo.

Além disso, a substituição de funções do Estado (como transporte coletivo, redes elétrica e de telefonia, assistência à saúde etc) que passaram a ser desempenhadas por grandes empresas (multi e transnacionais, inclusive) ajuda a acentuar essa confusão.

Segundo MARCONDES FILHO (2004, p. 106, grifos do autor):

“Essas empresas passam a adquirir status de entidades públicas, sem que haja qualquer tipo de oposição possível no plano do Direito. O Estado, atrofiado, incapaz, incompetente para qualquer 
intervenção nas sociedades, torna-se um organismo apenas legitimador, ou seja, que torna legítimas estas mesmas organizações das quais é dependente."

Por isso, a cada um resta buscar pequenos tempos e espaços íntimos dentro dessa exacerbação do trabalho, já que se vê roubado de sua intimidade. A individualização permanente dos mais variados equipamentos (receptores de mídias variadas, transporte etc) é um dos sinais desta busca.

“Em função disso, algumas válvulas de escape foram criadas. Cada vez mais as transições entre o público e o privado se faziam sentir no dia-a-dia. Ao sair de casa o indivíduo já se via sob a custódia do tempo. Os horários do ônibus, do trem, de chegada ao trabalho passaram a ser muito importantes. Estar em seu próprio carro no trajeto para o trabalho ou com o walkman num meio de transporte público eram maneiras de prolongar o tempo privado." (SCHITTINE, 2004, p. 57, grifos da autora $)^{43}$

A questão do tempo destinado à vida privada também passa a afetar 0 consumo dos produtos dos Meios de Comunicação. O crescimento da audiência para produtos destinados a abordar a vida privada pode ser relacionado a essa necessidade do homem moderno de prolongar o tempo privado. $\mathrm{E}$ esse aumento de audiência impulsiona os Meios a destinarem mais espaços a esse tipo de produto.

A valorização da intimidade, quer na construção dos espaços familiares, quer na busca de ocupação do tempo contribui para a identificação do isolamento como uma característica positiva. No pensamento de SENNETT (Cf. 2001), com a diminuição da participação na vida pública, as pessoas passam a se voltar insistentemente para as questões ligadas à sua

\footnotetext{
${ }^{43}$ Outro autor, Paul VIRILIO (Cf. 1993) concebe a cidade cada vez mais como espaços de passagem e não de convivência. Assim, a utilização dos tempos de deslocamento para atividades privadas (ou íntimas) é mais um encurtamento do tempo destinado às reuniões públicas.
} 
intimidade, privacidade e subjetividade. A pressão pela fusão das duas esferas (pública e privada) e a confusão resultante desta mescla, faz com que o indivíduo busque, cada vez mais, espaços pessoais e solitários. Na expressão de MARCONDES FILHO (2004, p. 46 , grifos do autor):

"O teatro do mundo, ou seja, as relações sociais que sempre foram marcadas por formalismos e encenações de comportamento entre as pessoas, reduzem-se nesta época. Já não se tem pejo, mesmo sendo figura pública, de abrir sua vida para toda a sociedade, numa demonstração clara de que íntimo e o social, o 'eu mesmo dentro de mim' e o mundo público lá fora são territórios que não se separam."

Isto terá reflexos intensos na forma de encararmos, na contemporaneidade, as histórias pessoais e sua relevância:

"Pois, se certamente sempre se escreveram histórias de vidas, por outro lado, a idéia de que a vida é uma história é moderna." (CALLIGARIS, 1998, p. 8)

CALLIGARIS (1998, p.4) fundamenta esta afirmação na obra de FOUCAULT ${ }^{44}$ que apresenta o ato de falar de si mesmo (ou escrever) como um "dispositivo crucial da modernidade, (...) já que a verdade é sempre e prioritariamente esperada do sujeito subordinada à sua sinceridade."

Por isso, é também a partir da Modernidade que o relato da vida pessoal passa a ser encarado como um gênero literário. Embora relatos autobiográficos escritos apareçam desde a idade clássica, a palavra era inexistente no grego clássico. Em inglês, a sua origem está no final do século XVIII e só tem sua efetivação nas primeiras décadas do século XIX. (CALLIGARIS, 1998, p. 7) $)^{45}$

\footnotetext{
${ }^{44} \mathrm{O}$ autor se refere à obra de Michel FOUCAULT: Histoire de la sexualité I. La volonté de savoir.

${ }^{45} \mathrm{O}$ autor lembra que também Biografia é uma palavra inexistente no grego clássico, tendo sua origem no Século $V$ e se afirmando na língua inglesa no século XVII.
} 
Segundo LEJEUNE (1986, p. 50, tradução nossa) podemos definir uma autobiografia como:

"Relato retrospectivo em prosa que uma pessoa real faz de sua própria existência, colocando ênfase em sua vida individual e, em particular, na história de sua personalidade."

Sua origem está fincada em duas correntes que convergem no individualismo moderno: as filosofias alexandrinas e o cristianismo. Segundo CALLIGARIS (1998, p. 7, grifos do autor):

"Ambas inventam e promovem a primazia do indivíduo autônomo sobre a comunidade, seja pela invenção de técnicas e éticas do self, seja (no caso do cristianismo) por relacionar os humanos com Deus um a um, como indivíduos, e não mais como membros de povos eleitos. Ambas também surgem em épocas de grande mobilidade geográfica, que forçaram 0 progresso da idéia do universalismo da espécie humana, corolário do individualismo. Ora, as filosofias alexandrinas dão um protótipo do diário íntimo nos pensamentos de Marco Aurélio, e o cristianismo nos dá - a cavalo entre diário íntimo e autobiografia - as confissões de Agostinho."

Mas não é só a autobiografia que representa o relato das histórias de vida humana. Podemos agregar ainda as memórias e os chamados diários (nesta categoria, em particular, os diários íntimos) como importantes instrumentos da narrativa de histórias de vida. É importante ressaltar que, apesar de seu grande apelo junto ao público, esse gênero literário tem reconhecimento menor por parte da crítica especializada.

Destas modalidades, a autobiografia e o diário íntimo (journal) são os que mantêm maior identidade entre si em seu vínculo com o individualismo moderno.

No entanto, LEJEUNE (1986, p. 50-2) afirma que embora a fusão entre autor-narrador dos diários íntimos remeta à identidade entre autor, narrador e personagem das autobiografias, 
a questão do tempo é crucial para a diferenciação dos dois. Nos diários, não há a rememoração, a narrativa não se dá sob retrospectiva a não ser em curtos espaços de tempo (um dia, ao final de um período - manhã, tarde, noite etc).

“Diferentemente do romance e da autobiografia que formam um todo artístico -, diários estão sempre em processo. Cada entrada diária representa um fragmento que é reconstituído, durante a leitura, pelo leitor. Como a vida do diarista está sempre em construção, ao contrário de outras narrativas que criam um mundo ficcional completo em torno delas mesmas - como o romance, a novela, a memória ou a autobiografia -, cada nova entrada pode ser uma surpresa para o leitor, em decorrência da estrutura do gênero." (OLIVEIRA, 2002, p. 71-2)

Historicamente, esse diário íntimo será o resultado da evolução de quatro tipos de diários ou pré-diários: os diários públicos $^{46}$, primeiros a serem registrados e tão antigos quanto a própria escrita, serviam à divulgação pública de fatos e eventos de interesse comunitário; os diários de viagem, que agrupam informações e relatos de experiências em torno de viagens e que aparecem a partir do século $X$, no Japão; os diários de registro/ memória pessoal (commomplace books) são livros de família, com leituras, quotas, observações, notas e desenhos; e, por fim, os diários de consciência ou espirituais, surgidos a partir do século XVI entre o clero reformado preocupado com a rigorosa auto-examinação espiritual. (OLIVEIRA, 2002, p. 30-42)

Destas experiências de relatar o cotidiano (sob vários aspectos: comunitário, familiar, espiritual etc) resultará o diário íntimo, espécie de Livro do Eu, cuja explosão se dá a partir do século XIX, embora registros desta narrativa possam ser encontrados desde o século $X$, no J apão.

\footnotetext{
${ }^{46}$ Segundo OLIVEIRA (2002, p. 31), os diários públicos estão associados a uma tradição de escrita comunitária cuja função de divulgação pública de fatos é semelhante à hoje desempenhada pelos jornais.
} 
Também aqui, o Iluminismo no século XVIII tem papel crucial na expansão desse gênero:

"Como constatam Alain Corbain e Michelle Perrot na passagem da História da vida privada relativa a esta época de intenso 'deciframento de si', o 'furor de escrever' tomou conta de homens, mulheres e crianças, imbuídos tanto pelo espírito iluminista de conhecimento racional como pelo ímpeto romântico de mergulho nos mistérios mais insondáveis da alma. A escrita de si tornou-se uma prática habitual, dando à luz todo tipo de textos introspectivos nos quais a autoreflexão se voltava não tanto para a busca de um certo 'universal' do homem, mas para a sondagem da natureza fragmentária e contingente da condição humana, plasmada na particularidade de cada experiência individual. " (SIBILIA, 2003, p. 3-4, grifos da autora $)^{47}$

Segundo OLIVEIRA (2002, p. 45), o principal marco da história dos diários íntimos, é o trabalho do escritor inglês Samuel Pepys (1633-1703) que escreveu durante dez anos 64 volumes de suas memórias, com observações e reflexões acerca do mundo físico, social e interior. Sua publicação só ocorreu em 1825, após sua descoberta e transcrição (o original foi todo feito em escrita taquigráfica).

Apesar disso, até hoje, o diário íntimo ainda é relacionado às mulheres, talvez por sua identificação com a manifestação da sensibilidade ou porque os aspectos da cultura relacionados ao privado passaram a ser vinculados ao âmbito feminino. Segundo OLIVEIRA (2002, p. 48), isso levou a que os diários fossem identificados como uma prática literária menor.

No entanto, SCHITTINE (2004, p. 104) nos mostra que, embora extremamente vinculado ao universo feminino, o diarismo não foi exclusivo das mulheres:

${ }^{47}$ Ela se refere à CORBIN, Alain; PERROT, Michelle. El secreto del individuo, p. 160. 
"Lejeune mostra que a prática do diário não foi de maneira alguma exclusiva ao sexo feminino, já que os primeiros diários de que se têm notícia são de homens. A verdade é que, a princípio, o século XIX parecia ser o mais pródigo no gênero. A idéia de que a vida daquele século era permeada por sentimentos de angústia, de estar à deriva, e de desencanto foi o que levou a se pensar que o escrito íntimo era uma característica dele. A manutenção de um diário como uma maneira de lidar com a vida era um recurso extremamente apropriado àquelas mulheres do século XIX e ao ritmo lento de suas vidas."

A afirmação é reforçada por BRIGGS; BURKE (2004, p.

41, grifos em negrito nossos, aspas dos autores) que registram a expansão e características desses diários ao falar sobre a circulação dos textos escritos e suas principais sedes:

"Como outras cidades do mundo mediterrâneo, Florença pode ser definida como uma cidade de notários, na qual os documentos escritos tinham função indispensável, sobretudo para registrar transferências de propriedades por ocasião de matrimônios ou mortes. A literatura laica era relativamente numerosa na cidade, e a prática de escrever diários ou crônicas encontrava-se bastante difundida. Exemplos desse tipo de documento pessoal também podem ser encontrados em outras cidades, como Augsburg, Barcelona, Bolonha, Londres, Nuremberg e Paris. Usualmente, essas 'autobiografias' focalizavam mais as famílias ou a cidade, e menos os indivíduos, e algumas vezes circulavam sob forma de manuscrito na comunidade urbana." 


\section{Por que contamos nossas histórias?}

São vários os motivos que levam os seres humanos a contarem suas histórias através de diários, autobiografias ou mesmo pela mídia e, dificilmente, um único deles seria capaz de explicar completamente a motivação de um único autor.

Parte desta explicação está vinculada às mudanças ocorridas entre os espaços público e privado, em que o encurtamento dos espaços destinados especificamente às vivências públicas associado à valorização da individualidade, levam o indivíduo contemporâneo a buscar novas formas de se projetar em sua sociedade. Ao lado disso, a própria aceleração do tempo associada ao movimentar-se sem fim causado pelos deslocamentos nas grandes metrópoles criam nos cidadãos a sensação de invisibilidade que tanto incomoda o indivíduo contemporâneo. Sua forma de vencer isso é, portanto, atrair o olhar do outro, ainda que por um instante.

Numa sociedade marcada pela movimentação como uma característica intrinsecamente positiva ${ }^{48}$, cada vez torna-se mais raro o ato de se debruçar demorada e atentamente sobre qualquer coisa ou situação de interesse. A própria forma de olhar foi profundamente modificada:

"A visão trabalha por varredura. Olhamos a cidade como um todo, nossos olhos passeiam de uma ponta a outra do horizonte vendo edifícios, veículos, pontes e viadutos, árvores e pessoas. Fazemos um apanhado geral da cena, olhamos tudo em 'plano geral', como dizem os cineastas. É evidente que dessa

\footnotetext{
${ }^{48}$ Ver Parte I, Sobre a Tese, Capítulo 1, Objeto e Justificativa, quando falamos sobre as mudanças no tempo e no espaço e a caracterização do "movimento pelo movimento".
} 
forma jamais estaremos atentos aos detalhes: àquela casinha abafada no meio dos prédios, àquele paralítico tentando subir a ladeira, às flores amarelas do ipê que começam a aparecer no final do inverno. Nietzsche dizia ainda que, pela velocidade terrível da vida, o espírito e os olhos acostumam-se com um olhar e um julgamento 'pela metade', ou mesmo falso, e que cada um de nós se parece com um viajante de trem, que só conhece um país ou um povo através de seu vagão. Isso quer dizer que vemos o mundo passar na rapidez, na velocidade, no agito cotidiano, e não nos detemos nas coisas. Não temos o olhar do fotógrafo, daquele que depurou o olhar e busca redescobrir as imagens esquecidas." (MARCONDES FILHO, 2005, p. 33, grifos do autor)

Numa abordagem parecida, um dos principais pensadores das Novas Tecnologias, Jakob NIELSEN (1997), afirma que a maioria das pessoas não lê as páginas da internet, seus olhos apenas escaneiam a tela, escolhendo palavras e sentenças. E apenas $16 \%$ lêem todo o texto, palavra a palavra. Com isso, a fragmentação é reforçada e a luta por destacar-se em meios a tantos fragmentos, maior. No entanto, esse destaque para o homem comum é a chance oferecida, na Modernidade, para que ele se equipare a seus heróis:

"Ao contar a própria história, a pessoa se coloca no centro do universo tanto quanto o público numa platéia que ouve um repentista se põe no espaço sonoro e é inundado pelo som que o circunda e faz da sua posição, seja ela qual for, um novo centro." (ROCHA, 2004, p.67)

É nesta expectativa que se cria toda uma nova comunidade de indivíduos prontos a autodocumentar suas trajetórias, transformando-as em relatos de folhetim ${ }^{49}$ e lançandoas para conhecimento de seus pares:

"Ora, se para um sujeito moderno falar de si responde à necessidade cultural imperiosa de construir

\footnotetext{
${ }^{49}$ CALLIGARIS (1998, p. 9) nos mostra que "Vivemos nossas vidas como romances e, reciprocamente, encontramos na literatura modelos para nossas vidas."
} 
ao mundo e a si mesmo no silêncio deixado pelo ocaso da sociedade tradicional, a série das fórmulas de seus atos autobiográficos deve nos informar de maneira privilegiada sobre seu devir, sobre os caminhos pelos quais ele se constituiu e, quem sabe, sobre o seu futuro. Neste sentido, uma história da subjetividade moderna é impensável sem o auxílio dos atos autobiográficos. (...) É a aventura pela qual o sujeito moderno, uma vez fundada a verdade em si e não mais no mundo, aprende a se dizer e, portanto, cria as condições de sua experiência." (CALLIGARIS, 1998, p. 12)

Multiplicam-se as formas e os equipamentos utilizados para o registro de cada história ou episódio de vida: de simples aparelhos celulares que registram cenas do dia-a-dia até sofisticados equipamentos adquiridos para a documentação da vida cotidiana. E, como veremos no capítulo seguinte ${ }^{50}$, caberá à contemporaneidade a criação de novos espaços para a difusão desses relatos.

Por outro lado, a explicação a essa questão da necessidade de narrar as histórias pessoais parte de uma complexa teia de motivos que transcendem às mudanças ocorridas entre os espaços público e privado e à forte individualização da cultura vivida a partir da Modernidade. Outros fatores, mais ligados a motivações internas do indivíduo e ao comportamento cultural das sociedades contemporâneas, também o levam a querer transformar sua história de vida pessoal em algo público.

Vários autores têm se ocupado em apontar essas diversas motivações. SCHIWY (1996, p. 18) faz um extenso levantamento apontando como objetivos de se fazer um diário: alargar a autoconsciência; explorar a identidade pessoal; ter um confidente/ colocar sentimentos e emoções sobre o papel; criar senso de continuidade em nossas vidas; preservar a memória de

${ }^{50}$ Capítulo 3. Por que contamos nossas histórias na mídia?. 
pessoas, eventos, de nós mesmos; lutar contra a descontinuidade, mudança, perda e angústia; explorar impulsos criativos; capturar idéias para estórias, poemas e outros projetos; recordar e explorar sonhos; celebrar graças e sucessos; engajar-se em um diálogo com o mundo em torno de nós; descobrir o que é sagrado em nossas vidas; aprofundar nossas jornadas espirituais; relembrar membros familiares e amigos queridos; entender a estória de nossas vidas; arrumar pensamentos e clarear idéias; fazer um balanço de nossas vidas, de tempos em tempos; clarear nossas propostas de vida; esquadrinhar o desejo do inconsciente.

Com base nesse levantamento, podemos pensar em objetivos relacionados a dois grupos de motivações principais: de um lado, a motivação de alargar sua autoconsciência e reinventarse [aqui, podemos destacar entre os objetivos apontados por SCHIWY (Cf. 1996): alargar a autoconsciência; explorar a identidade pessoal; ter um confidente/ colocar sentimentos e emoções sobre o papel; explorar impulsos criativos; capturar idéias para estórias, poemas e outros projetos; engajar-se em um diálogo com o mundo em torno de nós; descobrir o que é sagrado em nossas vidas; aprofundar nossas jornadas espirituais; entender a estória de nossas vidas; arrumar pensamentos e clarear idéias; clarear nossas propostas de vida; e esquadrinhar o desejo do inconsciente] e, de outro, a motivação do indivíduo se perpetuar, tornando perene sua história (estão neste grupo: criar senso de continuidade em nossas vidas; preservar a memória de pessoas, eventos, de nós mesmos; lutar contra a descontinuidade, mudança, perda e angústia; recordar e explorar sonhos; celebrar graças e sucessos; engajar-se em um diálogo com o mundo em torno de nós; relembrar membros familiares e amigos queridos; e fazer um balanço de nossas vidas, de tempos em tempos). 
No primeiro grupo, a motivação da autocompreensão e da própria reinvenção vem da tradição dos diários de consciência ou espirituais, com a possibilidade da utilização dos registros para a auto-avaliação da consciência, dos valores e do próprio sentido da existência. Paralelamente aqui acontece a reinvenção do sujeito: ao escrever sobre si, ele literalmente se produz.

"Narrar-se não é diferente de inventar-se uma vida. Ou debruçar-se sobre sua intimidade não é diferente de inventar-se uma intimidade. $O$ ato autobiográfico é constitutivo do sujeito e de seu conteúdo." (CALLIGARIS, 1998, p. 10)

Com isso entendemos o ato autobiográfico ${ }^{51}$, a narrativa da própria vida, como um ato performático, em que o indivíduo busca se reconstruir, modificando sua própria vida, aos seus olhos e aos olhos dos leitores. É por isso, que o escrito autobiográfico muitas vezes é comparado ao processo psicanalítico, o que em muito é relacionado ao fato de os dois serem produtos característicos da Modernidade e fundados no individualismo que marcou a proposta desta era. ${ }^{52}$

Ao narrar sua história, o homem assume o papel de autor de seu próprio script, consumando a emancipação advinda da individualização:

"O sujeito que fala ou escreve sobre si, portanto, não é o objeto (re)presentado por seu discurso reflexivo, mas tampouco é o efeito, por assim dizer, gramatical de seu discurso. Falando e escrevendo,

\footnotetext{
${ }^{51}$ Ao falarmos sobre o ato autobiográfico não estamos enfocando exclusivamente o gênero da Autobiografia que, como vimos no Capítulo anterior, difere em suas características dos demais gêneros de escrita de si mesmo, em particular os diários pessoais. Estamos, neste momento, enfocando o ato de relatar a própria história pessoal, independentemente do gênero escolhido para isso.

${ }^{52}$ Sobre a Psicanálise e a Modernidade, vale lembrar a citação de Sérgio Paulo ROUANET (1993, p. 101): "A psicanálise é a consciência infeliz do lluminismo, a adesão obstinada ao racionalismo, ao individualismo e ao universalismo da Ilustração e ao mesmo tempo a suspeita de que se trata, nos três casos, de uma luta perdida de antemão"
} 
literalmente, ele se produz." (CALLIGARIS, 1998, p.

10)

E esse novo papel de autor pode ser verificado, inclusive, quando a história é relatada por outrem. Segundo ROCHA (2004, p. 51-2, grifos da autora):

"Surge a figura do herói de si mesmo quando a história é contada por aqueles que a vivenciaram e o herói de seus conhecidos e familiares, muitas vezes filhos que também recordam nesse link as lembranças a eles repassadas por seus ascendentes de boca a ouvido na mesa de jantar de todos os dias."

Já o segundo grupo de motivações apresentado por SCHIWY (Cf. 1996) pode ser entendido pela ótica da perpetuação de uma história de vida, reunindo tanto a questão da construção de uma memória identitária como a forte vinculação à vaidade pessoal. Culturalmente, essa necessidade foi manifestada desde os tempos pré-históricos, quando os indivíduos registravam suas histórias e cotidianos nas paredes das cavernas. Antropologicamente, o homem sempre teve interesse em registrar para a posteridade o seu cotidiano:

\footnotetext{
"Imaginem os ancestrais do homem procurando expressar suas 'angústias' e perplexidade diante da realidade registrando, nas paredes das cavernas, momentos do seu cotidiano. Milhares de anos depois, a sociedade contemporânea continua fazendo a mesma coisa, em jornais, na tevê, no cinema e, até mesmo, nos muros das ruas das grandes cidades (os conhecidos 'grafites'). Agora podemos começar a entender essa conversa entre antropologia e comunicação". (PINHEIRO JÚNIOR, 2003, p. 1408, grifos do autor)
}

Inicialmente, podemos identificar e compreender a necessidade de registro da memória dos seres humanos como uma forma de vencer o tempo cronológico, em que coletar, guardar e recolher promove a atualização das lembranças do passado: 
"De qualquer forma, para vencer o tempo cronológico, o ser humano faz uso das artes da memória, constrói os lugares e os artefatos memoriais, físicos e cognitivos. Com a intenção de evitar o consumo, a deterioração, o homem tenta impedir a perda de sua memória nas brumas do passado, luta contra o esquecimento, sem se recordar de que para haver a memória é preciso existir o desaparecimento de algo, é preciso escolher, decidir o que será lembrado e que será entregue à ação das areias do tempo. A memória só pode existir enquanto mecanismo de seleção, como processo de escolha em todo o universo cultural humano de tudo o que deve ser lembrado e do que, por mais doloroso que possa parecer, é preciso largar, deixar escapar pelo caminho. O viajante não suportaria carregar consigo todo o universo por uma estrada, é preciso selecionar, priorizar o que será levado na viagem de acordo com a necessidade e a visão de mundo de cada pessoa, de cada tribo, de cada povo." (ROCHA, 2004, p. 36)

Mas a escolha do que levar à imortalidade tem fortes vínculos com os processos afetivos e o resgate da importância de tantos que permanecerão anônimos. O quê e quem lembrar? E como garantir a perenidade da lembrança?

Para responder, podemos recorrer a BOURDIEU (2005, p. 110-1, grifos do autor) que, em seu próprio escrito autobiográfico, num relato emocionado, imortaliza seu pai:

"Ficava mesmo feliz, acredito, sempre que podia ajudar os mais desfavorecidos, com quem se sentia à vontade e os quais depositavam nele confiança total; esbaldava-se em distribuir fornadas de gentileza e de paciência, e por vezes, já mais idoso, eu o censurava um pouco, por ajudar os mais pobres a se desvencilhar das papeladas que Ihe entregavam ('Aquets papès!', diziam), pensões de guerra ou por invalidez, formulários, mandatos etc., e lembro-me de ter chorado em diversas ocasiões ao pensar que seu nome, apesar de tantos méritos, não estaria no dicionário."

O processo de contar sua história (ou de seus entes queridos), permite portanto que seja feita, na atualidade, o resgate 
e a documentação do passado que será a garantia da imortalidade para a posteridade:

"O contar histórias pode integrar o presente, o passado e o futuro e criar a memória do futuro, que transcende a morte pela transmissão de um patrimônio comum." (ROCHA, 2004, p. 134)

Mas não é só o desejo de perpetuar as memórias mais queridas que move o autor de textos autobiográficos: ele também busca no interesse dos seus leitores por sua história, a satisfação de sua vaidade pessoal. É através da sedução de seus leitores que ele justifica a importância de sua vida. É o olhar do outro que fornece essa justificativa. Por isso, é importante que aquela vida retratada, as histórias, as emoções, os pensamentos passem a ter importância para a sociedade, deixem de ser questões apenas íntimas e se tornem de interesse público.

Nos diz CALLIGARIS (1998, p. 5):

"O escrito autobiográfico implica uma cultura na qual, por exemplo, o indivíduo (seja qual for sua relevância social) situe sua vida ou seu destino acima da comunidade a que ele pertence, na qual ele conceba sua vida não como uma confirmação das regras e dos legados da tradição, mas como uma aventura para ser inventada. Ou ainda uma cultura na qual importe ao indivíduo durar, sobreviver pessoalmente na memória dos outros - o que acontece quando ele começa a viver sua morte como uma tragédia, pois a comunidade pára de ser a grande depositária da vida, garantia de toda continuidade."

Essa é uma necessidade cada vez mais presente em nossos dias: a de fazermos de nossas histórias pessoais fatos especiais a ponto de justificarem nossa perpetuação, ou simplesmente nos discernirem dos demais seres humanos, chamando sua atenção para nós.

“É a visibilidade muitas vezes conferida ao comum, ao trivial pelo jornal, pelo rádio, pela televisão e, mais recentemente, pela Internet que podem transformar 0 
ser humano anônimo em estrela, ainda que por alguns momentos, ainda que num pequeno espaço cedido por um site no ciberespaço ou alguns instantes num programa de rádio (...)" (ROCHA, 2004, p. 80)

Mas se a sede de diferenciação ou de reforço da individualização é uma questão moderna, a busca de sentido para sua existência a partir do olhar do outro é um fenômeno que acompanha toda a história da humanidade. A teoria de LACAN (Cf. 1985) identificando a construção do eu a partir do espelho que é o outro tanto nos remete ao conjunto de motivações ligadas à autocompreensão e reinvenção quanto à necessidade de nos diferenciarmos da multidão e nos perpetuarmos através dos leitores.

Para avaliarmos as duas situações, precisamos primeiro nos debruçarmos sobre a questão da alteridade, compreendida como a condição de possibilidade de existência do eu (e de sua identidade).

"A identidade da autoconsciência não é algo prévio à alteridade, nem o outro constitui um momento posterior ao eu. A alteridade é a referência primeira e concomitante à constituição da própria identidade. $\mathrm{O}$ outro não é alguém posterior à configuração da pessoa, senão que constitui a condição de possibilidade para sua existência." (RUIZ, 2003, p. 55)

O homem, desde sua percepção como indivíduo busca suturar a fratura ocasionada pela percepção do Outro. Se, por um lado, o olhar do Outro funciona como um espelho em que confirmo minha existência, por outro, fornece a percepção de que sou incompleto, um ser faltante.

"O outro é, então, presença de alteridade: diferença, estranheza, novidade, contrariedade, infinitude, ignorância" (SIGNATES, 2000)

A busca da sutura desse ser fraturado é apresentada de diversas formas durante a história da humanidade. Da Natureza 
(Antiguidade) a Deus (Idade Média), foram várias as tentativas do homem em buscar sua completitude. Já em ESPINOSA (1973, p. 49, grifo nosso), a questão da Comunicação aparece como a forma do homem buscar de novo sua inteireza perdida:

"O que a parte tem em comum com o todo é aquilo por que ela se comunica".

Nos diz ABRÃO (2003, p. 4, grifos da autora):

"Expressões finitas e singulares da atividade da Substância, estamos necessariamente em relação uns com os outros. Essa relação, porque fundada no afeto (afecções no corpo; afetos na mente), é também, necessariamente, delicada. Complicada. O fato de afetarmos outros corpos e de sermos afetados por eles o tempo todo, de numerosas e diferentes maneiras, obriga a mente ao esforço de articular e associar as idéias provocadas por essa troca variada de afecções, a fim de estabelecer entra elas uma conexão que faça algum sentido. Esse esforço de conhecer as existências singulares que nos afetam a partir do mundo externo e que por isso promovem em nós alterações (corporais e psicológicas) internas é imaginativo (perceptivo)."

No entanto, esse preenchimento através da Comunicação também não é possível, já que o estabelecimento do elo pressupõe a separação entre o eu e o outro, reforçando na verdade a experiência primordial que é de solidão e isolamento:

"Fundada na alteridade, a comunicação, em seu objetivo de incorporar-se a UM, só o faria pela anulação de si própria. O ser na linguagem é sempre o ser em oposição e alteridade. Reduzi-lo a Um é convertê-lo ao limite da comunicação, por via de sua morte.

Porém, como nela se busca o preenchimento da falta constituinte, temos de reconhecer o engodo na crença de que essa falta pode vir a ser preenchida, de que a comunicação deve ser objeto de crítica por não estar cumprindo esse papel: espera-se dela que atinja o limite intocável. Se a religião denega a falta e coloca sua sutura no encontro com Deus a ser consumado na morte, se a ciência rodeia a falta procurando circunscrevê-la e a arte nela mergulha pela pulsão de morte a partir de um discurso 'enviesado', a comunicação, ao contrário, é a constante repetição, a 
tentativa de sutura impossível e, por isso, sem fim." (GOMES, 2001, p. 182, grifos da autora)

É essa repetição sem fim, um dos principais argumentos para que cada um busque suturar a fratura através da Comunicação. E com a expansão dos meios de comunicação, passamos a buscar essa sutura também a partir da mídia como veremos a seguir. 


\section{Por que contamos nossas histórias na mídia?}

Não há como não observar o papel dominante que os meios de comunicação exercem hoje em nossa sociedade. Podemos mesmo afirmar que vivemos numa sociedade media centered, tal a importância que esses meios adquiriram. E com a revolução tecnológica empreendida primeiro com os meios eletrônicos e mais recentemente com os meios digitais, esse centramento parece a cada dia mais evidente.

Esse papel está intimamente ligado às mudanças ocorridas na esfera pública e que vimos anteriormente. $\mathrm{Na}$ verdade, é um processo fortemente vinculado ao papel que a comunicação tem na configuração dessa esfera. E, neste caso, falamos da comunicação em geral e não especificamente da comunicação social:

"Na conversação dos cidadãos entre si é que as coisas se verbalizam e se configuram; na disputa dos pares entre si, os melhores se destacam e conquistam a sua essência: a imortalidade da fama. Assim como nos limites do oikos a necessidade de substância e a manutenção do exigido à vida são escondidos com pudor, a pólis oferece campo livre para a distinção honorífica: ainda que os cidadãos transitem como iguais entre iguais (homoioi), cada um procura, no entanto, destacar-se (aristoiein)." (HABERMAS, 1984, p. 16-7, grifos do autor)

E é de se esperar que, se os meios de comunicação substituíram a praça pública grega na era moderna, a nova configuração da esfera pública agora passe por eles.

POLISTCHUK e TRINTA (2002, p. 78, grifos dos autores) ressaltam que a origem da palavra mídia é fortemente vinculada à esfera pública, podendo ser vista como seu sinônimo: 
"... seu significado era 'meio', 'espaço

intermediário'. Além disso, dizia também 'lugar para onde tudo converge'; logo, "praça pública'."

E mais, a busca pelo destaque também passa a ser conduzida dentro dos meios de comunicação: é lá que os homens buscam brilhar.

"De nada adianta eu produzir uma obra, ter idéias extraordinárias, inventar ou descobrir coisas que não eram até então conhecidas se não puder passar por esse grande alto-falante geral da sociedade. Essas coisas que eu posso ter jamais serão conhecidas, pode-se dizer 'nunca existiram'. Ou seja, o que garante que as coisas de fato existem é o fato de serem veiculadas pelos meios de comunicação." (MARCONDES FILHO, 2004, p. 64, grifos do autor)

Essa afirmação é reforçada por Adriana SANTOS (2002, p. 67):

“Aliás, a Comunicação parece mesmo ser a religião dominante no início deste terceiro milênio, quando nada parece acontecer verdadeiramente se não for notícia."

A adesão a essa nova religião implicará em mudanças significativas na vivência cotidiana, quer no universo público ou privado:

“Assim, são os meios de comunicação que atestam que as coisas vivem, eles dão um certificado de que aquilo de fato existiu. Isso tem influências radicais em todas as coisas que antes existiam, independentemente da sua divulgação para a sociedade toda. Uma greve, uma guerra, uma revolução, uma erupção vulcânica, a queda de um avião, um tremor de terra, a morte de uma personalidade famosa, o nascimento de alguém que será herdeiro de alguma coroa, enfim, todos os assuntos que antes pertenciam à sociedade e que valiam por si, pelo fato de acontecerem e as pessoas deles tomarem conhecimento através da disseminação da informação, como notícia que passa de boca em boca, tal como o boato, todas essas coisas hoje já não tem mais a garantia de que de fato existem." (MARCONDES FILHO, 2004, p. 64) 
Assim, Meios de Comunicação não só se constituem no local onde ocorrem os debates, mas também se configuram nos autores primeiros das temáticas que serão debatidas pelos próprios homens (agenda setting). Com isso, revestem-se de dupla importância para o ser humano.

Substituindo a praça pública como o lugar por onde passam os debates e aparecem as temáticas que devem pautar as discussões e preocupações dos homens, os meios de comunicação se organizam como centro da sociedade da era moderna e se preparam para o papel de reorganizadores dessa mesma sociedade.

“Nós não vemos (...) a realidade (...) como ela é, mas como são nossas linguagens. E nossas linguagens são nossas mídias. Nossas mídias são nossas metáforas. Nossas metáforas criam o conteúdo de nossa cultura." (POSTMAN, 1985, p. 15)

Esse poder dos Meios de Comunicação de modificar o conteúdo de nossa cultura, de reinventar o próprio mundo, é o que irá conferir à nossa sociedade a característica de media centered. Afinal, é a forma da construção dos sentidos que vai caracterizar cada etapa da história humana. $\mathrm{Na}$ contemporaneidade, reconstruímos o mundo através das mídias:

"A teia de significados socialmente instituídos é diferente e inédita em cada sociedade, pois cada grupo social recria o mundo com um sentido novo. Ela se configura de forma particular em cada coletivo, socializando os indivíduos e constituindo sua identidade pessoal e social." (RUIZ, 2003, p. 61)

Este novo poder de encantamento fortalece a busca do homem pelo espaço dentro dos Meios de Comunicação. Afinal, se a imortalidade da fama, como vimos, já era considerada importante na praça grega, o que dizer da Ágora Moderna? Existir nos Meios 
de Comunicação é condição sine qua non para a fama e a busca da imortalidade através dela.

"O fim do mundo antropocêntrico e da ilusão de atuação eficaz na sociedade, na história, na cultura, entram em concorrência com a realidade maquínica de mundos virtuais, em que a existência física, palpável, concreta desce a um segundo plano. Assim, é-se hoje acometido de um tipo de angústia especial e até então desconhecida, a de ter que demonstrar que se está vivo.

À necessidade de demonstração da própria concretude soma-se uma certa desinibição generalizada (...), que funciona como contrapondo neurótico da mesma anomalia. Trata-se de um 'vir à luz' da intimidade de cada pessoa, reduzindo a importância do outro, dos demais, a forma encontrada para se dar cidadania à insignificância como única prova cabal da sobrevivência. O grande homem, o herói, o ídolo morreram. Os anões estão aqui, apesar de sua baixa estatura, para demonstrar tragicamente que 'morri mas existo'." (MARCONDES FILHO, 2004, p. 92, grifos do autor)

Os próprios meios trataram de valorizar isso e de criar mecanismos para incentivar essa busca de espaços de legitimação da fama ou da importância do próprio público. Ainda no século XVIII, os jornais (que se tornavam o centro das discussões nos cafés) abriam espaço para a participação dos leitores publicando seleções de cartas com as manifestações do público. O chamado homem comum começava a participar desse novo espelho, buscando se destacar dos demais pelas suas opiniões a respeito de determinado assunto. E o meio de comunicação alimentava esse desejo: HABERMAS (1984, p. 59) lembra o espaço criado dentro de um tradicional café pelo jornal Spectator somente para o recebimento de cartas do público.

Essa busca de participação fez com que o jornal se tornasse o centro das discussões empreendidas e, ao mesmo tempo, o local onde era possível expressar as opiniões, onde o público, de fato, se colocava: 
"O público que lê e comenta tudo isso tem aí a si mesmo como tema. (...) As experiências, sobre as quais um público, que apaixonadamente tematiza a si mesmo, busca no raciocínio público das pessoas privadas entendimento mútuo e esclarecimento, essas experiências fluem de fontes de uma subjetividade específica: o seu lar é, em sentido literal, a esfera da pequena-família patriarcal." (HABERMAS, 1984, p. 5960)

E esse é um dos pontos mais fortes dos Meios de Comunicação neste cenário de mediadores entre os homens e sua sociedade: ao mesmo tempo em que fornece o espaço para a discussão, transforma o homem comum em personagem, deslocao para o centro do noticiário. Assim os meios são, em parte a nova praça pública, em parte o espelho onde nos vemos refletidos.

Na questão da sutura da alteridade, não há dúvidas que os Meios de Comunicação substituíram o papel destinado a Deus no Medievalismo. MATTELART (2002, p. 39) diz que a Comunicação passou a ter o papel de religar os seres humanos antes destinado à religião (a palavra tem origem do termo latino religare= religar, reunir).

"A fratura só pode ser suturada fugazmente por meio do sentido criado. O sentido constitui, pois, a ponte que liga ambos. Todo sentido é sempre uma construção simbólica" (RUIZ, 2003, p. 59)

E como vimos em POSTMAN ${ }^{53}$, o sentido contemporâneo é construído a partir dos Meios de Comunicação.

Assim, expor-se na mídia significa ocupar o espaço da praça pública, encontrar o espelho que reflita (e confirme) nossa identidade e ao mesmo tempo suturar a fratura imposta pela alteridade.

Mas a mudança mais recente é a do foco que a presença do homem tem tido nas mídias. Se no início da expansão dos Meios

\footnotetext{
${ }^{53}$ Citação neste capítulo, à p. 86.
} 
de Comunicação, a participação era vinculada aos temas comuns e - destaque obtido pela manifestação individual sobre essas temáticas, agora o enfoque é cada vez mais relacionado à exposição das histórias pessoais.

Como vimos nos capítulos anteriores ${ }^{54}$, a valorização da individualização e da intimidade, gerou toda uma frente de iniciativas relacionadas à sua documentação e divulgação. $E$, se nada existe se não foi veiculado por um Meio de Comunicação, também a história pessoal, a vivência individual passa a ser projetada na mídia:

"A verdade do sujeito mudou de forma. Portanto, sua vida e seu ato autobiográfico tendem a constituí-lo com uma imagem que vive no e pelo olhar dos outros." (CALLIGARIS, 1998, p. 18)

Na visão de SFEZ (2000, p. 59), essa nova verdade é construída através da exposição a que me submeto ao mesmo tempo em que acompanho a vivência do outro:

"Visto que Deus se ausentou do nosso mundo moderno, para escapar do solipismo, devemos reportar-nos à comunidade dos observadores que, como eu, constroem uma realidade. Enquanto observo, sou observado. Faço então parte da observação de um Outro, semelhante a mim, e só existo na medida em que esse outro - ou esses outros - me integra em seu sistema"

E na fragmentação característica da Contemporaneidade, serão os fatos comuns do cotidiano que merecerão a atenção do público:

"A vida comum transforma-se em algo espetacular, compartilhada por milhões de olhos potenciais. E não se trata de nenhum evento emocionante. Não há histórias, aventuras, enredos complexos ou desfechos maravilhosos. Na realidade,

\footnotetext{
${ }^{54}$ Parte II, Capítulos 1. Contextualização e Histórico e 2. Por que contamos nossas histórias?
} 
nada acontece, a não ser a vida banal, elevada ao estado de arte pura." (SIBILIA, 2003, p. 9)

Parte como resposta a essa necessidade, parte como motor que a impulsiona, os Meios de Comunicação participarão efetivamente deste processo, o que representará a busca de novas fórmulas/espaços para atender a esta demanda ${ }^{55}$, inicialmente com foco nas celebridades para, logo a seguir, ampliar seu campo de interesse também para o homem comum.

A própria condição essencial para se tornar uma celebridade estará ligada à presença nos meios de comunicação e a fama é, cada vez mais, uma noção vinculada à mídia, ambas particularmente relacionadas ao imediatismo que marca a percepção contemporânea:

"Enquanto a posteridade fica confinada às obras, os contemporâneos têm uma experiência direta ou quase direta, pelos jornais, pelo rádio, hoje pela televisão, mas ainda pelo boato e pela intriga, da pessoa em sua totalidade, de seu corpo, de suas maneiras, de sua indumentária, de sua voz, de seu sotaque - traços que, salvo alguma exceção marcante, não deixam vestígios nos textos -, bem como de suas ligações, de suas tomadas de posição políticas, de seus amores e de suas amizades etc)." (BOURDIEU, 2005, p. 55)

Neste contexto, a busca pela auto-divulgação parece anular os últimos conflitos ligados à preservação da intimidade que cercaram as discussões iniciais sobre os diários pessoais. Não há mais dúvidas, no sistema midiático contemporâneo, que os novos autores buscam a exposição e a cumplicidade do público às suas histórias.

\footnotetext{
${ }^{55}$ A questão da forma com que o homem comum passa a ser valorizado nos Meios de Comunicação e dos espaços que são criados para dar espaço a essas manifestações será abordada a seguir na Parte III - Histórias Pessoais e Mídia, de forma geral no Capítulo 1. O sistema midiático contemporâneo e de forma específica nos Capítulos referentes a cada tipo de mídia.
} 
De um lado, essa necessidade está vinculada ao poder de reinvenção conferido às narrativas autobiográficas. Mas a exposição é, principalmente, a resposta contemporânea à ausência de perenidade conferida pela vivência do imediatismo:

"A partir do momento em que o alvo, o objetivo não passa de uma vã palavra, e que a distinção entre grupos se deve sobretudo ao totem em torno do qual se agregam, o cacife é o ganho imediato. O ganho do poder, do reconhecimento, da notoriedade, etc. é antes de tudo 'presenteísta'." (MAFFESOLI, 1996, p. 19, grifos do autor) 
III. HISTÓRI AS PESSOAIS E Mí DI A

“Para que as personagens possam viver, devem contar." (Tzvetan Todorov. As estruturas narrativas) 


\section{O sistema midiático contemporâneo}

Desde o surgimento da imprensa, não demorou muito para que os meios de comunicação de massa se estruturassem como um sistema com ligações com todas as áreas da sociedade e que se posicionasse como centro dessa mesma sociedade.

Afinal, a invenção da prensa de Gutenberg não completou ainda 600 anos (quase nada perto dos $7 \mathrm{mil}$ anos da criação da escrita e dos 4 mil anos da introdução do alfabeto). E, apenas três séculos depois do estabelecimento da imprensa (que é associado ao século XVI), o termo "quarto poder" já era usado para se referir a ela ${ }^{56}$.

Se considerarmos, então, os demais meios de comunicação, esse ciclo entre criação, expansão e fixação fica cada vez menor. O exemplo mais recente, da internet, que só foi aberta ao público em geral há pouco mais de 10 anos e hoje já se encontra disseminada, é a concretização dessa questão.

É claro que a formação do grupo de meios de comunicação como um sistema não depende apenas do ciclo individual de cada mídia, mas sim do estabelecimento de relações entre elas e do reposicionamento das mídias existentes diante da criação e expansão dos novos meios. Nos dizem BRIGGS; BURKE (2004, p. 17):

"A mídia precisa ser vista como um sistema, um sistema em contínua mudança, no qual elementos

\footnotetext{
${ }^{56}$ Diz-se que o termo foi criado pelo historiador Thomas Babington Macaulay (1800-59) para se referir à Galeria de Imprensa no Parlamento britânico. No entanto, o The Times passou a adotar o termo para si mesmo e a expressão foi utilizada como título de um livro sobre imprensa pelo jornalista F. Knight Hunt, em 1850. (BRIGGS; BURKE, 2004, p. 197).
} 
diversos desempenham papéis de maior ou menor destaque."

E mais à frente:

“Pensar em termos de um sistema de mídia significa enfatizar a divisão de trabalho entre os diferentes meios de comunicação disponíveis em um certo lugar e em um determinado tempo, sem esquecer que a velha e a nova mídia podem e realmente coexistem, e que diferentes meios de comunicação podem competir entre si ou imitar um ao outro, bem como se complementar." (BRIGGS; BURKE, 2004, p. 33)

É certo que, a cada novo meio que surge, uma nova adequação é feita no sistema estabelecido. Inicialmente, a mídia recém-criada se apropria do modelo e linguagens estabelecidos pelos anteriores. Assim, em seu primeiro momento, o jornalismo praticado no rádio era praticamente a leitura a notícia do impresso, assim como a televisão inicialmente reproduzia os programas de rádio inserindo neles imagens: as primeiras estáticas como as páginas de uma revista. No entanto, depois, o novo meio vai desenvolvendo suas próprias características e vive sua expansão até atingir o centro do sistema midiático. A partir daí, os meios mais antigos vivem a crise e têm que buscar adequações para se reposicionar dentro do sistema.

A cada período de expansão de uma nova mídia, sempre ocorre a discussão sobre o fim das anteriores: não seria a televisão, a morte do rádio? Ou agora não é a internet o golpe fatal contra a imprensa?

No entanto, como vimos em BRIGGS; BURKE (Cf. 2004), apesar do fatalismo que freqüentemente cerca as discussões, as mídias coexistem e seus papéis de competidores ou complementares não são fixos, sendo estabelecidos dentro de um sistema que é vivo e não estático. Também FIDLER (Cf. 1996), 
BOLTER; GRUSIN (Cf. 1999), MANOVICH (Cf. 2001) e SALAVERRÍA; SÁBADA (Cf. 2004), entre outros, têm se dedicado a esta questão, abordando, sob diferentes aspectos, a coexistência e as inter-relações entre mídias.

"O que eu estou querendo dizer é que os meios, como extensões de nossos sentidos, estabelecem novos índices relacionais, não apenas entre os nossos sentidos particulares, como também entre si, na medida em que se inter-relacionam. O rádio alterou a forma das estórias noticiosas, bem como a imagem fílmica, com o advento do sonoro. A televisão provocou mudanças drásticas na programação do rádio e na forma das radionovelas." (MCLUHAN, 2000, p. 72)

Essa estruturação dinâmica é, em muito, apoiada nas próprias mudanças da sociedade, principalmente de tecnologia para o transporte das informações. Assim, se a expansão dos jornais dependeu da forma com que ele podia ser transportado (e de até onde era possível levá-lo) para ser distribuído, a questão do rádio e da televisão passou pelo alcance das emissoras e pela condição de aquisição dos aparelhos receptores pelo público e a internet convive com as limitações e ofertas de conexão para seu funcionamento.

A tecnologia está ainda na base das discussões acerca das condicionantes sobre as mensagens emitidas por este sistema midiático: “O meio é a mensagem”, nos diz MCLUHAN (2000, p. 21), no clássico livro que passou a ser revisitado pelos pesquisadores de comunicação a partir da expansão das Novas Tecnologias. É importante ressaltar que, durante anos, MCLUHAN assim como a teoria desenvolvida na Escola de Toronto de Comunicação, foram tidos como deterministas e suas idéias afastadas do referencial teórico das pesquisas em comunicação. No entanto, principalmente a partir da década de 90 , sua obra passou a ser objeto de revisão e 
seu pensamento reinterpretado dentro de uma ótica culturalista, como explica PEREIRA (2006, p. 7, grifos do autor):

“Observe-se que McLuhan está (...), explicitamente reconhecendo que o fundo de qualquer tecnologia é, por um lado, a situação que dá origem, que ocasiona a própria tecnologia, por outro, todo o ambiente, o conjunto de serviços e desserviços, ou, genericamente, as afetações, que esta mesma tecnologia passa a promover. Em ambos os casos a idéia de cultura estaria bastante presente socializando a tecnologia."

No caso do sistema de mídias é, em parte, a partir desses condicionamentos, que cada meio irá encontrar um papel mais específico dentro do conjunto. Por exemplo, os jornais diários deixaram de concorrer com o rádio (e também com a televisão, ainda que em menor grau) na disputa pela divulgação mais rápida dos fatos e eventos, já que o imediatismo ${ }^{57}$ radiofônico não podia ser suplantando. No entanto, resolveram sua posição no sistema, publicando informações mais complexas que as que podem ser transmitidas pelo rádio ${ }^{58}$.

A chegada da internet representou uma nova readequação no sistema midiático, já que ela vem tentando competir com a rapidez do rádio para difundir informações, impulsionada pela facilidade com que se pode publicar hoje uma notícia na web. De novo o desenvolvimento da tecnologia vem criando outros cenários que permitem aos meios buscar novos papéis: hoje, a expansão dos notebooks e das redes wireless permitem a jornalistas e outros interessados publicarem notícias na internet de muitos lugares no mundo.

\footnotetext{
57 Segundo ORTRIWANO (1985, p. 80), o imediatismo pode ser definido como a capacidade do meio de transmitir uma notícia ao mesmo tempo em que o fato se desenrola.

${ }^{58}$ Neste caso, o condicionamento técnico do meio radiofônico, limita as mensagens àquelas de mais fácil apreensão por parte do público, já que não há a possibilidade de consultar depois para tirar dúvidas, característica denominada Instantaneidade.
} 
"Grandes mudanças nas formas de comunicação do ser humano podem ser encaradas como atualização e mediação ao invés de anulação de formas anteriores de cultura." (ROCHA, 2004, p. 16)

Ao descrevermos essas mudanças, estamos enfatizando o poder que a tecnologia tem para condicionar (e não determinar) as ações dos meios de comunicação e o poder que o uso que é feito dessas técnicas tem de se posicionar como motor das mudanças culturais na sociedade.

"Através de tudo isso, a troca com o mundo externo ocorre cada vez mais pela máquina e cada vez menos existe uma realidade em estado puro." (MARCONDES FILHO, 2004, p. 40)

Esse relacionar-se com o mundo através dos meios de comunicação (e das tecnologias desenvolvidas por e para eles) está cada vez mais presente no dia a dia, no cotidiano de todos, e permeia todos os momentos e ambientes: do trabalho ao mais íntimo.

O próprio conceito da comunicação passa a ser definido pelos fluxos, já que ela está enredada em todos os níveis da sociedade.

\footnotetext{
"Na cidade dos fluxos comunicativos contam mais os processos que as coisas, a ubiqüidade e instantaneidade da informação ou da decisão via telefone celular ou fax (...)" (MARTí N-BARBERO, 1998, p. 62)
}

Ou no dizer de GOMES (2001, p. 26):

"Por toda parte se fala em comunicação. O avanço das mídias, tudo interpenetrando, chama a si até as funções antes delegadas a instituições oficiais, espaços de reivindicação de direitos. (...) O campo da comunicação (...) assume proporções vastíssimas, o que nos situa no cruzamento de muitas vias."

Além da inter-relação entre seus vários meios de comunicação e entre eles e as diversas esferas da sociedade, o 
sistema midiático de comunicação também pode ser assim caracterizado em função dos verdadeiros conglomerados em que se transformaram suas empresas, com vertentes e associações com diversas áreas de tecnologia da informação.

"Isso se dá também com os sistemas sociais -
como o da comunicação - que se agigantaram
tornando-se 'complexas estruturas' de caráter
nacional, donos de toda uma rede de satélites,
retransmissoras, estações que cobrem o país inteiro e
que fornecem informações, telenovelas, esporte,
programas humorísticos." (MARCONDES FILHO, 2004,
p. 39, grifos do autor)

As chamadas Novas Tecnologias da Informação têm papel preponderante nas mudanças operadas a partir e no sistema midiático contemporâneo. De um lado, porque permitem que, pela primeira vez na história, se possa armazenar e trabalhar com um grande volume de dados com velocidade e mesmo à distância.

Não se trata, entretanto, de falar sobre o grande volume de produção, problema que já foi sentido no século $X \mathrm{VI}{ }^{59}$, mas sim da acessibilidade a essas informações de maneira rápida e também à distância.

De outro lado, a circulação rápida da informação provoca a necessidade de gerar cada vez mais nova informação para ser consumida, já que o próprio sentido do "envelhecimento" da notícia passou a ser mais rápido.

O primeiro resultado será a produção de informações cujo objetivo primordial não é mais informar e sim substituir a anterior que se tornou velha, como explica MARCONDES FILHO

\footnotetext{
${ }^{59}$ BRIGGS; BURKE (2004, p. 29) nos mostram que a multiplicação dos livros no século XVI trouxe sérias necessidades de ampliação das Bibliotecas e de organização e publicação de catálogos que auxiliassem o leitor a se encontrar: "Era um oceano no qual os leitores tinham de navegar, ou uma enchente de material impresso em que era difícil não se afogar".
} 
(2004, p. 51, grifos do autor), ao abordar o papel dos meios de comunicação em nossa sociedade contemporânea:

"Pela sua própria magnitude e crescimento, tornaram-se máquinas, com finalidade quase nula, que simulam entreter. Produzem uma massificação de informações, um amontoado fantástico e alucinante de dados, que o público recebe com relativa indiferença. Funcionam e produzem incessantemente notícias sobre notícias, que criam um clima de 'estar sendo informado', quando, na verdade, mais fazem encenação. É produção de informação para não se informar coisa alguma."

Do outro lado, para o público, criou-se a overdose de informação:

"Somos uma cultura que se consome em informação, e muitos de nós nem se perguntam como controlar esse processo. Agimos com a suposição de que a informação é nossa amiga, acreditando que as culturas podem sofrer muito com a falta de informação e, claro, sofrem. Só agora se começa a compreender que as culturas também podem sofrer muito com o excesso de informação, informação sem sentido, informação sem mecanismo de controle." (POSTMAN, 1994, p. 78)

Essas novas configurações fazem parte do que CASTELLS (Cf 1999) intitulou de Sociedade Informacional. Segundo ele, toda a sociedade passou a se organizar a partir da produção, distribuição e consumo dos insumos informacionais baratos, numa revolução de dimensões semelhantes à Industrial. SAAD (2003, p. 242) comenta esta estruturação:

"... as bases da sociedade informacional incluem a relação entre tempo e espaço, o papel das cidades como o espaço dos fluxos e dos lugares de ocorrência da comunicação, e a função das mídias, fornecendo as informações locais e as redes digitais fazendo a conexão global.

São funções relacionais - global e local - que devem ser assumidas pela empresa informativa, desde que haja uma compreensão do que é comunicar e transmitir informações nesse novo ambiente. Castells, em entrevista específica sobre o tema, considera que 
essa compreensão já era anterior à explosão da Internet."

Essa questão da cidade é fortemente abordada por MARTÍN-BARBERO (1998, p. 62), que vê na fragmentação dos espaços a oportunidade para que os fluxos comunicacionais passem a se estabelecer como centro das novas relações da sociedade:

"Na cidade disseminada e impossível de ser totalmente abarcada, só os meios de comunicação possibilitam uma experiência-simulacro da cidade global."

No entanto, os próprios meios de comunicação estão na base dos elementos irão gerar a sensação da cidade fragmentada:

"O espaço público se desintegra, o fluxo, a fragmentação, a reclusão doméstica e a comunicação, mediada pela televisão e pelas novas tecnologias, reconfiguram hábitos e culturas, criando diferentes sociabilidades". (MARTíN-BARBERO, 1998, p. 53)

Essa experiência se torna fundamental quando olhamos a nova configuração da esfera pública, a partir da formação do sistema midiático. Afinal, a percepção de que, através dos meios de comunicação, conseguimos olhar para o mundo (ou a cidade) de forma geral e particular, transfere para essas mídias o papel de aglutinador de debates e reflexões sobre as questões comuns.

"(...) o espaço público contemporâneo pode ser designado por 'espaço público mediatizado', no sentido em que é funcional e normativamente indissociável do papel dos media." (WOLTON, 1995, p. 167, grifos do autor)

É importante, no entanto, frisar que a configuração desse novo espaço público não inclui apenas os meios de comunicação mas também todo um conjunto de fontes profissionais de que se servem esses meios: órgãos governamentais, institutos de pesquisa, especialistas, bancos de 
dados, departamentos de comunicação e divulgação de instituições e empresas. (LAGE, 1998, p. 231)

Mas, é dos meios de comunicação o papel central nessa estruturação e cabe a eles a representação do espaço de debate para a população. Nesse sentido, cada mídia integrante do sistema buscará formas próprias, dentro de suas especificidades, de desempenhar essa função.

A projeção para os meios de comunicação desse papel de centro por onde passam as questões vitais à sociedade confere a eles um status de lugar onde tudo acontece, numa representação da própria realidade:

"De uma forma geral, atualmente não se fala mais em acontecimento fora das mídias. Isto é, só há acontecimento se ele for público, se houver uma oferta de sentidos, mediada pelos meios de comunicação, para a opinião pública. Assim, passaríamos a tratar da expressão 'acontecimento midiatizado'. Os fatos que acontecem todos os dias, mas que não são veiculados pela mídia passam a ser apenas ocorrências e não acontecimentos." (BORELLI, 2001, p. 3, grifos da autora)

Uma das conseqüências mais diretas será a projeção para as mídias de tudo que o público desejará legitimar como "real", inclusive sua vida pessoal ${ }^{60}$, impactando fortemente as programações e os assuntos abordados pelos meios de comunicação.

A questão tem origem na valorização do homem comum e da vida cotidiana que vai se intensificando na contemporaneidade. A própria ciência desloca seu foco em sua direção:

"Este herói anônimo vem de muito longe. É o murmúrio das sociedades. (...) Mas, nas

\footnotetext{
${ }^{60}$ Conforme visto na Parte II - Falando de Nós, Capítulo 2. Por que contamos nossas histórias?
} 
representações escritas, vai progredindo. Pouco a pouco ocupa o centro de nossas cenas científicas. Os projetores abandonaram os atores donos de nomes próprios e de brasões sociais para voltar-se para o coro dos figurantes amontoados dos lados, e depois fixar-se enfim na multidão do público. Sociologização e antropologização da pesquisa privilegiam o anônimo e - cotidiano onde zooms destacam detalhes metonímicos - partes tomadas pelo todo." (CERTEAU, 1994 , p. 57)

A própria História tem deslocado seu foco do relato feito a partir das personalidades conhecidas para a história construída a partir dos relatos de anônimos, pessoas comuns. Não se trata mais de olhar para os acontecimentos somente a partir daqueles que os viveram no centro do poder e das decisões mas também sob o ângulo do homem comum.

Nos meios de comunicação, a questão é fortemente sentida nas programações/publicações, que passam a explorar temas do cotidiano e da vida íntima, primeiro das celebridades e, em seguida, do público comum. Paralelamente, trata-se de transformar em espetáculo aquilo que até então era banal.

"A vida comum transforma-se em algo espetacular, compartilhada por milhões de olhos potenciais. E não se trata de nenhum evento emocionante. Não há histórias, aventuras, enredos complexos ou desfechos maravilhosos. Na realidade, nada acontece, a não ser a vida banal, elevada ao estado de arte pura." (LEMOS, 2002, p. 12)

Novamente o foco é deslocado para o homem comum que se transforma em personagem dos meios de comunicação.

No dizer de LEMOS (2002, p. 13):

"Compartilhando a banalidade podemos suportar melhor a existência. E o mesmo acontece com aquele que é visto, já que ser visto é também estar junto. Revelar a privacidade é aqui um exercício que pode e deve permitir a conexão. No fundo estamos sempre lutando contra a solidão, o desencontro e o estranhamento." 
Não é possível indicar qual foi a primeira experiência com este tipo de narrativa, embora todos os meios de comunicação as tragam (com maior ou menor destaque, é claro). No entanto, alguns pontos se destacam na observação desse fenômeno.

Na mídia impressa, o surgimento do Jornalismo Literário (que também tem influência em outros meios mas que tem sua base principal no impresso $)^{61}$ trouxe o destaque para vida desses personagens até então um tanto anônimos. Mas foi a partir dos programas populares, primeiro do Rádio e depois da Televisão, que as histórias de vida do homem comum passaram a ter destaque para o grande público, dominando inclusive os voltados às classes populares.

Outro ponto a ser destacado, ainda nas TVs foi 0 aparecimento e desenvolvimento dos reality shows ${ }^{62}$, fenômeno do final do século $X X$ e que tem se mantido fortemente no início do século XXI. Tais programas reúnem pessoas para viver o que seria a vida cotidiana sob as lentes da televisão e vigilância do público em ambientes de confinamento (ou controlados) e, em geral, pela disputa de algum prêmio.

Como característica comum entre esses diversos tipos de narrativa (do Jornalismo Literário aos reality shows) podemos apontar o fato de que elas se revestem de elementos de ficcionalidade ${ }^{63}$, podendo ser compreendidas como "novelas da vida comum" e o público passa a acompanhar essas experiências de vida como a uma obra de ficção.

\footnotetext{
${ }^{61}$ Conforme veremos no próximo Capítulo - Mídia Impressa.

62 Falaremos mais detidamente sobre o assunto nesta Parte da Tese, Capítulo 3. Mídia Eletrônica, na abordagem sobre Televisão.

${ }^{63}$ Em entrevista a Paulo SAMPAIO e Deborah GIANINI (2005), Maria Immacolata Lopes compara essas novas narrativas às telenovelas, destacando que a base de ambas é o melodrama.
} 
Esses elementos são fruto da utilização, pelos meios de comunicação, da tecnologia disponível como nos mostra Maria Cristina COSTA $(2004$, p. 1):

"... a tecnologia de que se vale a indústria cultural acaba por introduzir elementos de trucagem, simulação e dissimulação que, não só favorecem a produção ficcional, como acabam por inserir em toda a programação um alto grau de ficcionalidade."

O interesse do público, quer por voyerismo, por identificação, ou por necessidade de projetar sua realidade no sistema por onde passa a criação das redes de significação contemporâneas, manifesta-se pelo consumo elevado desse tipo de produção.

"E que obra poderia ser maior, mais tocante do que aquela que se realiza diariamente pelas mãos de cada ser humano?" (ROCHA, 2004, p.130)

Com isso, de seu início nos programas/publicações de variedades, hoje as histórias pessoais estão presentes em todas as outras áreas da indústria de comunicação.

Outra característica do sistema midiático contemporâneo (além da permanente reorganização entre as várias mídias e seus papéis dentro do sistema e o papel central ocupado por este na sociedade, inclusive com a substituição do espaço público tradicional) é justamente uma divisão não muito clara entre os vários tipos de espaços dentro das programações/publicações.

Assim se, de início, espaços de informação, publicidade e entretenimento eram bem separados, o próprio desenvolvimento dos meios tem acabado com as fronteiras mais visíveis. É cada vez mais comum encontrarmos elementos de jornalismo utilizados na publicidade e vice-versa (hoje falamos até em publi-reportagem) e os próprios limites entre entretenimento e informação, desde a 
década de 50, têm se tornado indefinidos. (BRIGGS; BURKE, 2004, p. 196)

A própria espetacularização da notícia contribuiu para atenuar as linhas divisórias, trazendo para o campo da informação a encenação da notícia. Com isso, são cada vez mais comuns exemplos de programas/publicações que misturam as duas vertentes, tornando as classificações cada vez mais flexíveis.

Mas o fenômeno que mais teve impacto sobre o sistema midiático no que se refere às histórias pessoais foi a recente explosão dos blogs ${ }^{64}$, a partir da metade dos anos 90 . O fenômeno trouxe à tona a questão da relação direta entre público-autor e meio de comunicação sem a mediação dos profissionais da área.

As experiências com a criação de espaços para autoria do público não foi resultado das Novas Tecnologias nem surgiu com a internet e os blogs. ${ }^{65}$ No entanto, a possibilidade do público veicular seus próprios conteúdos e sem passar por nenhum filtro ou seleção, isso sim é novo e tem reflexos concretos tanto na configuração do sistema midiático e de suas características quanto nas demais mídias que o compõem.

Inicialmente, podemos destacar o papel dos profissionais de Comunicação - e entre eles, os de Jornalismo neste novo cenário, em que o processo de relacionamento emissorreceptor está em franca transformação, como destaca SAAD (2003, p. 130, grifos da autora):

\footnotetext{
${ }^{64}$ Veremos esta questão no Capítulo 4. Mídia Digital.

${ }^{65}$ Além dos espaços destinados pelos meios impressos, os meios eletrônicos, em particular o Rádio fizeram diversas experiências com essa participação. As mais recentes envolvem os ouvintes como repórteres fornecendo informações sobre trânsito etc. Esta mesma experiência começa a se tornar marcante nos Portais, principalmente em caso de coberturas de grande acidentes - 11 de Setembro foi um marco.
} 
"Constata-se na prática dos publishers que o processo de relacionamento emissor-receptor está em plena transformação, muitas vezes assumindo um caráter metafórico, quando observamos alguns processos de transição adotados por grandes complexos multimídia; e, em outras, um caráter de reinvenção da mídia existente, uma re-mediação, quando se observam ações que buscam a criação de novos processos de produção de conteúdo e de relações com o mercado para a sustentação de um negócio completamente novo."

Ao mesmo tempo, um outro rol de profissionais começa a se integrar aos modos de produção da comunicação e de seus conteúdos, gerando novos desafios aos profissionais das áreas tradicionais. A ação de engenheiros, informáticos, designers hoje caminha tão proximamente do jornalismo como a publicidade e o marketing.

"A migração à informatização, no conjunto da produção audiovisual, deve supor uma mudança na preparação cultural dos profissionais. Os técnicos, empregados em diferentes fases da cadeia de produção multimídia, deverão ser polivalentes. Tanto a organização empresarial como o exercício da profissão tenderão a impor a estrutura do sistema informático. O uso da documentação em linha e a ênfase na pósprodução converterá os profissionais, de criadores únicos, em mediadores do processo. (...) Os produtores de conteúdos serão técnicos e os técnicos deverão ser produtores de conteúdos. As empresas de comunicação se preparam para esta fusão de competências profissionais." (VILCHES, 2003, p. 47) ${ }^{66}$

Para os profissionais de comunicação, além da estruturação de suas funções frente a novas áreas, está também posta a questão de sua relação com o público e o papel a ser desempenhado no novo cenário.

De um lado, a necessidade da produção contínua de informações novas, empurra o jornalista para o papel de

\footnotetext{
${ }^{66}$ VILCHES defende que a disputa pelo comando da comunicação será travada entre os setores de telecomunicações, informação jornalística e os meios audiovisuais.
} 
instantaneísta, relatando o que acaba de ocorrer e sem a possibilidade de desenvolver uma narrativa mais apurada que quebre a sentença da informação pela informação.

Por outro, é colocado a ele o desafio de lidar como mediador não mais apenas das informações recebidas mas também com os conteúdos que são produzidos e veiculados sem seu crivo e que passam por uma comunicação direta entre público-público.

Os reflexos nos produtos finais e nas teorias da Comunicação já podem ser sentidos:

"Estão se dando grandes mudanças, por exemplo, nas estratégias de agenda setting. As sociedades virtuais permitem inverter as regras das agendas informativas dos meios tradicionais. (...) Enquanto os meios jornalísticos selecionam, a priori, a informação, os sites web das sociedades virtuais de alguns organismos acolhem tudo e são os usuários os que, com seus comentários e resenhas, selecionam o que deve permanecer." (VILCHES, 2003, p. 53, grifos do autor)

Mas não é só na Internet que essas experiências proliferam. O Citizen Journalism - Jornalismo Cidadão, Jornalismo Participativo ou Jornalismo Colaborativo reúne não jornalistas para a produção de informações (às vezes, mas não sempre, em colaboração com jornalistas) e não se restringe à web, embora tenha ganhado força a partir das ferramentas desenvolvidas para ela (wikis, blogs etc). Mas embora as experiências se caracterizem por uma maior liberdade na produção e veiculação das notícias, ainda são muito criticadas pela falta de precisão nas informações publicadas.

É importante ressaltar que todas essas modificações não são um mero resultado da introdução das Novas Tecnologias da Comunicação mas, antes, um processo de transformação da própria relação entre sociedade e sistema midiático, potencializado 
pelas inovações tecnológicas. Como resultado, temos o rompimento com os esquemas clássicos de Comunicação e a adoção de um modelo circular horizontal:

"Congregados à revolução digital e à diversidade de expectativas dos consumidores, nos achamos ante uma só certeza: a de que os modelos clássicos de teorias e técnicas da comunicação serão tão obsoletos como o modelo clássico de difusão do conjunto dos meios, da produção dos conteúdos e da oferta de serviços que dominaram o século XX." (VILCHES, 2003, p. 47)

E mais à frente:

"No entanto, o termo comunicação coletiva - que também passa a ser utilizado - tem a ver com a interação permitida pelas tecnologias, com a circulação horizontal da informação e com as práticas comunicativas." (VILCHES, 2003, p. 51)

Essa nova configuração irá contribuir, e muito, no fortalecimento da chamada Indústria da Interatividade, termo cunhado para definir um conjunto de técnicas e ações que teriam por objetivo permitir ao público a participação ativa junto a produtos, inclusive dos meios de comunicação.

Associa-se o boom do uso do adjetivo Interativo nos meios e produtos de comunicação (como sinônimo de produtos diferenciados) aos anos 80/90, com a explosão da penetração da Informática e da cultura de redes em nossa sociedade.

“...com o cyberspace, as clássicas indústria cultural e indústria da consciência cedem lugar ao que se poderia denominar provisoriamente de indústria da interatividade" (TRIVINHO, 1998, p. 117, grifos do autor)

No entanto, antes da mídia, foi a arte que impulsionou o uso do termo já nos anos 60 , com as criações/instalações que levavam o público a penetrar nas obras, experimentando outras sensações que não apenas a apreciação visual. Neste sentido, 
destaca-se, no Brasil, o trabalho de Hélio Oiticica e seus parangolés que eram vestidos pelos visitantes. A idéia era fazer o público participar da obra de arte, interagindo com a criação do artista. (SILVA, Marco, 1998, p. 2)

Na pop art está também a origem da idéia de fusão sujeito(público)-objeto(obra) a partir do conceito de interpenetrabilidade.

Mas, anterior ao uso do termo Interatividade como atributo de valoração dos produtos está o do conceito de Interação. Originário da Física (MULTIGNER apud SILVA, Marco, 1998, p.2), refere-se à alteração do movimento de determinadas partículas provocado pelo movimento de outras partículas. Segundo MULTIGNER, o conceito de Interação migrou da Física para a Sociologia, e de lá para a Psicologia Social até ser incorporado pela Informática.

Na Informática, o termo Interatividade passa a ser utilizado a partir dos anos 80 e está associado à transição do computador de uma máquina rígida a um equipamento conversacional, com interfaces amigáveis (SILVA, Marco, 1998, p.3). A incorporação do hipertexto e ferramentas que possibilitavam trocas entre usuários, em contraponto à unidirecionalidade característica do contexto comunicacional da época também influencia a adoção e alastramento do uso do termo.

Na Comunicação, a origem da valorização está na proposta de bidirecionalidade que sempre permeou o debate sobre mídia. Já nos anos 20, com o advento do rádio, BRECHT (Cf. 1981) revelava o sonho de que meios de comunicação fossem vias de duas mãos, tirando o papel de passividade destinado ao público. 
Nas décadas de 60 e 70, vários autores e movimentos trabalharam a questão da bidirecionalidade comunicacional. Com o ambiente contestatório que marcou essas décadas, o fluxo unidirecional dos então chamados meios de comunicação de massa (e, inclusive, o conceito de massa) parecia cada vez mais inadequado.

Na Comunicação, dois fatores básicos têm aparecido como comuns aos vários estudos e abordagens da Interatividade: a bidirecionalidade (com a fusão sujeito-objeto) e o grau de participação.

Sobre o primeiro fator, a bidirecionalidade, Marco SILVA (1998, p. 9) destaca:

"A bidirecionalidade diz respeito ao modo como a comunicação é arquitetada dentro do meio de comunicação, tendo em vista os dois pólos da comunicação que são o emissor e o receptor. Ou seja, o funcionamento do meio de comunicação deve ser concebido a partir do princípio que diz: só existe comunicação a partir do momento em que não há mais nem emissor nem receptor e, a partir do momento que todo emissor é potencialmente um receptor e todo receptor é potencialmente um emissor. Portanto, comunicação é bidirecionalidade entre os pólos emissor e receptor, ou seja, comunicação é troca entre codificador e decodificador sendo que cada um codifica e decodifica ao mesmo tempo."

A partir do momento em que ao receptor é permitido também emitir, ele passará a interagir diretamente com o meio, numa fusão sujeito-objeto (ou em nosso caso, receptormensagem, homem-máquina).

"A nova comunicação da web é um amálgama entre mensagem, emissor, meio e receptor - um interagindo nos demais e todos interagindo em um. Cai o conceito estanque de emissor-mensagem-meioreceptor." (BARBEIRO; LIMA, 2001, p. 39) 
PRIMO; CASSOL (2007, p. 3) ressaltam que a interação é definida pelas "... relações e influências mútuas entre dois ou mais fatores, entes, etc. Isto é, cada fator altera o outro, a si próprio e também a relação existente entre eles".

Essa alteração mútua entre público e meio de comunicação (ou mensagem) significa, como já destacado, uma mudança fundamental no esquema clássico da comunicação em que os papéis são separados. Nesta nova definição, o produto (ou mensagem) tem conteúdos manipuláveis e a natureza de cada elemento é alterada.

Na visão de ALONSO; MARTínEZ (2003, p. 271, tradução nossa), meios interativos são os que:

“...permitem a relação e participação do usuário com o meio, com os anunciantes ou com outros usuários. A interatividade proporciona a possibilidade de passar da comunicação vertical dominante nos meios tradicionais a uma comunicação horizontal, e de uma comunicação de massas a uma comunicação personalizada e segmentada."

Sobre a participação, a questão central está em seus vários graus de possibilidade e o potencial efetivamente interativo de cada. Isto porque se ao falarmos da bidirecionalidade e da fusão sujeito-objeto, enfocamos a relação entre dois agentes, ambos com poder de agir sobre o outro, quando abordamos a participação, encontramos os mais diversos graus e classificações.

PRIMO; CASSOL (2007, p. 7) ${ }^{67}$ destacam três níveis de participação relacionados à Interatividade: reativo, coativo e proativo. No primeiro, as opções são dadas pelo meio/programa, havendo pouco controle por parte do usuário do processo ou dos

\footnotetext{
${ }^{67}$ A análise aborda a questão dos ambientes educativos mediados pelo computador mas pode, sem prejuízos, ser deslocada para a questão da Comunicação Social.
} 
conteúdos; suas ações geram apenas feedback para os meios, sem possibilidade de alteração direta dos conteúdos. No nível proativo, o usuário pode controlar tanto a estrutura quanto o conteúdo; seu grau de participação permite a ele, de fato, interagir com o meio. $\mathrm{O}$ nível coativo é o intermediário entre os outros dois e prevê as possibilidades de controle da seqüência, ritmo e estilo.

Embora em todos os três níveis haja participação do usuário, apenas o último (proativo) gera, de fato, interação, pois possibilita a bidirecionalidade e a efetiva relação entre público e meio.

ORTRIWANO (2000) aborda a questão da participação sob o ponto de vista do jornalismo e divide as possibilidades oferecidas pelos meios em participação adjetiva e subjetiva. A participação adjetiva é aquela em que o público pode, no máximo, escolher entre opções pré-fornecidas (enquetes, por exemplo) e essas escolhas são utilizadas como feedback para o processo. Já a participação substantiva teria em si o poder de produzir modificações no meio e em sua programação.

Com isso, podemos associar a Interatividade a processos que permitam que a comunicação seja bidirecional, permitindo ao usuário emitir ao invés de apenas receber e que esta emissão produza alterações no produto/mensagem e no próprio meio de comunicação.

Apesar de constatarmos que a maioria das possibilidades de participação oferecidas pelos meios de comunicação ainda está distante da participação proativa ou substantiva, devemos aceitar que a própria incorporação do termo usuário modifica o status e a natureza do papel do público. 
Iniciada com a crise com o conceito de massa ${ }^{68}, 0$ surgimento da figura do usuário na comunicação está fortemente ligado ao estabelecimento de uma sociedade de consumo, em que o papel de cidadão exercido na discussão em espaços públicos é substituída pelos direitos privados e o papel do consumidor ${ }^{69}$.

O novo papel também está fortemente vinculado à identidade contemporânea baseada na fragmentação em vários níveis e na multiplicidade. A afirmação do indivíduo se dá agora pela diferença e não mais pela igualdade (como no Universalismo do pensamento iluminista). Cada um escolhe dentre as suas diversas identidades (sexo, raça, religião, opção sexual, faixa etária, profissão, grupos sociais etc) qual responde a que apelo em que momento.

"O sujeito, previamente vivido como tendo uma identidade unificada e estável, está se tornando fragmentado; composto não de uma única, mas de várias identidades, algumas vezes contraditórias ou não-resolvidas." (HALL, 1999, p.12)

Na Comunicação esta questão se manifesta com a individualização e personalização dos produtos comunicacionais suplantando as noções de agrupamento. O que importa agora é oferecer produtos que atendam totalmente a cada indivíduo, em todas as suas peculiaridades. O nosso receptor emergiu da massa e ao invés de receber a mensagem passou a usar o meio para obter o que deseja: informação, entretenimento, serviços etc. Os novos meios seriam como grandes cardápios em que cada um poderia escolher o que mais lhe agrada e consumi-lo.

\footnotetext{
${ }^{68}$ Raymond WILLIAMS (1969, p. 313) afirma que como "massa" adquiriu sentido pejorativo, nunca consideramos que nós mesmos e/ou as pessoas ligadas à nós sejamos parte da massa: "Não considero massa meus parentes, amigos, vizinhos, colegas, conhecidos; nenhum de nós age ou pode agir assim. As massas são sempre os outros, aqueles que não conhecemos e não podemos conhecer." (1969, p. 209)

${ }^{69}$ Sobre isto ver CANCLINI, Néstor Garcia. Consumidores e Cidadãos: conflitos multiculturais da globalização.
} 
No entanto, é questionável o quanto esses processos têm promovido a efetiva Interatividade, levando a uma comunicação dialógica:

"No estado atual das coisas, ainda se está muito longe disso. No máximo, consegue-se que o receptor comunique ao canal emissor sua opção de compra, seus gostos jornalísticos ou seu programa preferido. Ou seja, o telespectador ainda está relegado à condição de mero consumidor, não tendo tecnicamente condições de exercer plenamente seu direito de participar, opinar e criticar." (MARCONDES FILHO, 2006)

Essa limitação das possibilidades de Interatividade tem reflexos diretos na atuação do público em relação aos meios, como se quando pudessem, de fato, dialogar com a mídia, interferir nos conteúdos, o fizessem de forma tímida e limitada. Maria Cristina COSTA (2004, p. 9, grifos da autora), narrando a experiência vivida com o projeto As formas narrativas em mídias eletrônicas ${ }^{70}$, mostra que o usuário participa apenas timidamente da interação proposta:

"A única interatividade possível aberta ao espectador tem sido a expressão de juízos de valor gosto ou não gosto; isto está correto, isto está errado - presente no zapping, nas cartas que são enviadas às emissoras e jornais, nas pesquisas de audiência e de opinião e nas participações via telefone de programas como Você Decide. Habituados a essa 'interatividade' desenvolvida em décadas de convívio com a indústria cultural, o público, mesmo diante de possibilidades maiores de interferência, tende a reagir da forma habitual."

Em parte, essa timidez também é relacionada à falta de domínio técnico da nova linguagem. Para interagir com o novo meio é preciso familiarizar-se e dominá-lo primeiro. Sem a intimidade com a tecnologia e com seus ambientes, dificilmente a interação poderá se concretizar.

\footnotetext{
${ }^{70}$ http: //www.eca.usp. br/narrativas
} 
"A emergência das mídias digitais veio alterar radicalmente esse cenário. Elas não se afinam nem se harmonizam ao mundo do usuário - impõem-se provocando um sentimento de estranhamento e até de inicial repulsa. Exigem domínio técnico, concentração, recepção ativa e oferecem ao público um ambiente artificial e técnico que parece deslocar os usuários de seu cotidiano." (COSTA, 2004, p.2)

Falta de hábito e dificuldades naturais referentes a um novo ambiente tecnológico constituem-se, portanto, em duas das principais limitações para o exercício pleno da Interatividade por parte do usuário. Aliadas aos problemas apresentados pelos próprios meios, constituem os principais entraves para que a Interatividade proposta tenha o real sentido de interação. 


\section{Mídia I mpressa}

Para falarmos dos espaços destinados pelos meios de comunicação impressos às histórias pessoais de seu próprio público, devemos abordar o assunto por dois ângulos: o dos espaços destinados ao público e o dos espaços destinados às histórias pessoais (e intimidade).

No que se refere à participação do público, devemos ressaltar que o primeiro meio de comunicação - o jornal - não demorou a abrir espaços para o seu público também escrever e publicar no próprio veículo.

Logo na seqüência, quando os jornais passam a ser complementados por revistas (final do século XVII), e depois com seu desmembramento em veículos de circulação independente dos jornais, estas também passam a criar seus próprios espaços para o público.

E embora não existam registros específicos acerca da participação do público na imprensa escrita ${ }^{71}$, as referências a esses espaços aparecem em várias obras principalmente a partir do século XVIII com a expansão da mídia.

Os registros iniciais (tanto dos jornais quanto das revistas) estão fortemente associados às seções de cartas, espaços destinados ao público para manifestar suas opiniões,

\footnotetext{
${ }^{71}$ Esses registros sistematizados inexistem também em relação aos demais meios de comunicação. As referências a essas participações são encontradas em trabalhos de temáticas mais gerais e apresentadas dentro de outros contextos. Essa questão somada ao tamanho do universo pesquisado, torna impossível um levantamento histórico abrangente apenas como parte de um trabalho, motivo pelo qual, nesta tese, apenas indicaremos fatos e exemplos relevantes de forma a iniciar uma abordagem histórica que representaria uma outra pesquisa mais específica.
} 
relatar problemas, fatos e até mesmo suas histórias ou simplesmente dialogar com o veículo de comunicação buscando informações, tirando dúvidas etc.

Para HABERMAS (1984, p. 48-61), o fenômeno está associado ao surgimento dos cafés na metade do século XVII e sua expansão no século XVIII, atingindo camadas mais amplas da classe média e transformando-se no palco onde se davam as repercussões dos jornais e lançamentos em geral.

Diz HABERMAS (1984, p. 58, grifos do autor):

"Quando, em 1709, Steele e Addison publicaram os primeiros números do Tatler, os cafés já eram tão numerosos, os círculos dos freqüentadores dos cafés já eram tão amplos que a coesão desse círculo multiforme só podia ser mantida através de um jornal"72

$\mathrm{Na}$ época, em Londres, já havia mais de três mil cafés, o que dá a dimensão de sua importância para a organização social.

"Os artigos de jornais não só são transformados pelo público dos cafés em objeto de suas discussões, mas também entendidos como parte integrante deles; isto se mostra no dilúvio de cartas, das quais os editores semanalmente publicavam uma seleção. As cartas dos leitores, quando o Spectator se separa do Guardian recebem uma instituição própria: na parte Oeste do café Button's é colocada uma cabeça de leão, por cuja garganta o leitor podia jogar as cartas." (HABERMAS, 1984, p. 59, grifos do autor)

É neste contexto que as seções de cartas se tornam um instrumento dialógico importante entre público e veículo de comunicação de um lado, e, por outro, entre elementos do público com os demais leitores.

A história do The Spectator e a forma com que estimulava a participação do público também aparece em BRIGGS;

\footnotetext{
72 HABERMAS se refere a Joseph Addison (1672-1719) e Joseph Steele (1672-
} 1729), editores do The Spectator, publicado em 1711-12. 
BURKE (2004, p.55-79), que destacam não só a impressão de algumas na seção correspondente mas também a influência que as missivas tinham na escolha dos temas a serem abordados pelo jornal, inclusive nos artigos para discussão. O primeiro número da publicação já trazia um anúncio solicitando que o público ("aqueles que tiverem idéias para se corresponder conosco") mandasse cartas para o jornal.

No Brasil, um grande exemplo de como a participação do público pode receber destaque por parte do jornal, envolve $\mathrm{O}$ Estado de S. Paulo, que já em torno de 1915, deslocava da seção de cartas aquelas que tinham maior poder de repercussão:

"Por essa altura, irritado com as queimadas dos caboclos nas fraldas da serra da Mantiqueira, que destruíam os capoeirões próximos de sua fazenda no Buquira, município de Caçapava, um fazendeiro enviou à seção 'Queixas e Reclamações' do Estado de S. Paulo o trabalho 'Velha Praga', a que o jornal, inteligentemente, deu destaque, publicando fora daquela seção. Assim estimulado é que o fazendeiro José Bento Monteiro Lobato foi enviando ao jornal o que tinha na gaveta e novas coisas que escrevia, contos e artigos, e o público foi se habituando a admirar o seu estilo fácil, correntio, simples, claro, muito diferente do dos escritores que colaboravam nas folhas da época. Quando deu por si, o fazendeiro estava em S. Paulo, 'a dirigir a Revista do Brasil, a escrever e a editar livros, e sobretudo a revolucionar, sem pensar na coisa, a produção, comércio e distribuição de livros de todo o país."' (SODRÉ, 1966, p. 393-5, grifos do autor) ${ }^{73}$

Mas, muito antes disto, a questão dos espaços destinados ao público para que ele possa dividir com os demais leitores suas insatisfações já aparecia na imprensa brasileira. O Diário do Rio de Janeiro, de 1821, por exemplo:

“...ocupava-se quase tão somente das questões locais, procurando fornecer aos leitores o máximo de informação. Inseria informações particulares e

\footnotetext{
${ }^{73} \mathrm{~A}$ citação que ele faz é de Leo Vaz. Páginas Vadias. Rio de Janeiro: 1957.
} 
anúncios: aquelas tratavam de furtos, assassínios,

demandas, reclamações, divertimentos, espetáculos, observações meteorológicas, marés, correios; estes tratavam de escravos fugidios, leilões, compras, vendas, achados, aluguéis e, desde novembro de 1821, preços de gêneros." (SODRÉ, 1966, p. 58, grifos nossos)

A participação do público também é estimulada em enquetes e votações que tradicionalmente acompanham grandes eventos. A Gazeta, jornal comandado por Casper Líbero, em São Paulo nas décadas de 20 e 30, protagonizou alguns fortes episódios deste tipo: num evento célebre de lançamento do Concurso Mundial de Beleza (correspondente em nossos dias ao Miss Universo), em 1929, sua "Página Feminina" faz a eleição da representante da capital paulista (Senhorita Cidade de São Paulo) através de votação dos leitores por bairros. Diariamente, o jornal publicava cupons que deveriam ser recortados, preenchidos e devolvidos ao jornal que contabilizava os votos (HIME, 2002). Em outra circunstância, em 1931, junto com a Rádio Educadora Paulista, o jornal volta-se para o incentivo da produção musical, com o patrocínio de um concurso de música brasileira. Foram eleitos pelo público (novamente com a estratégia de publicar os cupons que deveriam ser preenchidos e devolvidos) e premiados com um conto de réis os melhores instrumentistas de violino, piano, flauta, saxofone, violão, trombone, piston, banjo, cavaquinho, bandolim, clarinete e bateria e os melhores cantor de música líder nas paradas de sucesso, cantor popular, cantora de música brasileira, declamador e declamadora, compositor de música líder e compositor de música popular. O jornal recebeu durante o concurso quase 20.500 cupons-resposta. (HIME, 1997, p. 196)

Com o início da adequação de espaços e funções, no início do século $X X$, entre revistas e jornais no Brasil, os jornais 
passam a voltar-se mais para a publicação de notícias enquanto as revistas desdobram-se naquelas com temáticas mundanas ou críticas, mas sempre com uma vocação literária (SODRÉ, 1966, p.340). Com isso, a participação do público com sua própria produção literária ganha espaço e destaque nas revistas.

$\mathrm{Na}$ Inglaterra, um pouco antes do The Spectator, outro jornal viveu a experiência de estimular a participação dos leitores na feitura da publicação, desta vez, na posição de indicar quais as informações sobre as quais gostariam de ter suas dúvidas esclarecidas. O The Athenian Mercury respondia a perguntas encaminhadas pelo seu público, mostrando as raízes da discussão sobre meios interativos. Em seus seis anos de existência, o jornal fundado pelo livreiro londrino John Dunton "para resolver todas as questões interessantes e curiosas propostas por pessoas inteligentes", respondeu a cerca de seis mil perguntas de seus leitores (BRIGGS; BURKE, 2004, p.79).

A experiência perdura até os dias de hoje, com as seções destinadas a responder dúvidas/perguntas encaminhadas pelos leitores. Essas seções, em geral, são organizadas por assuntos e abrangem as mais diversas áreas: de conselhos para aplicações financeiras à sexualidade. São também publicadas seções não fixas, ligadas a eventos com sazonalidade (como, por exemplo, dúvidas quanto ao Imposto de Renda na época da declaração).

O estilo das colunas e seus assuntos de abrangência variam de veículo para veículo, mas, em linhas gerais, podemos destacar dois tipos principais de formatação: um em que as perguntas são publicadas (algumas vezes com a omissão do nome do autor) e respondidas diretamente; e outro em que as respostas são dadas a grupos de perguntas sem citá-las especificamente. 
Neste caso, as cartas servem para levantar assuntos a serem abordados por determinada coluna. Um bom exemplo, são as colunas de saúde e beleza da "Página Feminina", de A Gazeta, durante as décadas de 30 e 40:

“...devemos destacar, porém, as colunas escritas por médicos, como Estética e beleza, assinada pelo dr. João Paulo Vieira, de dezembro de 1934 a março de 1935, Qual é seu conselho, doutor?, publicada entre 1934 e 1936, e Conselhos de um Dermatologista, publicada de 1936 em diante. Procuram esclarecer a infinidade de dúvidas que chegam ao jornal, por intermédio de cartas. Sem responder diretamente a cada uma delas, tratam dos assuntos mais questionados pelas leitoras." (HIME, 2002, p. 250, grifos da autora)

Os vários tipos de colaborações do público (perguntas, sugestão de temas, textos, informações, fotos etc) encontram na mídia impressa um maior espaço a partir, principalmente, de sua conceituação como Jornalismo Colaborativo ou Jornalismo Cidadão $^{74}$ (do inglês Citizen Journalism). Encontramos veículos totalmente baseados nestes relatos do público e, ao mesmo tempo, nos produzidos por profissionais, uma maior valorização desta participação. Isto se dá pela própria necessidade dos veículos se mostrarem participativos, em oposição ao modelo pelo qual ficaram conhecidos: o de um meio de comunicação de uma só mão.

Nos grupos que expõem suas questões ou participam da confecção dos veículos que lêem, tal qual na criação de comunidades locais em torno dos cafés e suas publicações, podemos observar o fortalecimento da identidade comum estabelecida, levando o público a olhar para si mesmo e suas temáticas no espelho da mídia. E, através das seções de cartas,

\footnotetext{
${ }^{74}$ Conforme conceito apresentado na Parte III - Histórias Pessoais e Mídia, Capítulo 1. O sistema midiático contemporâneo, à p. 109.
} 
oferece-se a este mesmo público o papel de autor de suas próprias questões (ainda que de maneira sucinta e sob o controle do veículo) numa indicação clara de que as tentativas de ruptura do modelo comunicacional rígido de emissor-receptor dentro do sistema midiático antecedem, e muito, às Novas Tecnologias de Comunicação.

"Assim, práticas não legítimas e mais espontâneas encontram-se representadas, enquanto, antes, elas não entravam nos códigos e temas da representação. Benjamin observa até que pode nascer, com o cinema e o jornal, uma confusão de papéis entre produtor e consumidor. Nos jornais, a diferença entre redator e leitor se desmancha quando o leitor se torna autor, graças às cartas dos leitores." (CHARTIER, 1999 , p. $82-3)^{75}$

Outro exemplo significativo da importância desta autoria por parte do público, ainda que limitada a uma seção, é apontado por BRIGGS; BURKE (2004, p. 79-80) no que se refere à temática do suicídio. Eles apontam, a partir da obra de Michael MacDonald e Terence Murphy (Sleepless Souls, de 1990), que a atitude simpática sobre o ato é fortemente influenciada pelo tom adotado pelos jornais ingleses do século XVIII:

"Essa impressão foi-se criando pela freqüência dos relatos que mostravam o suicídio como coisa comum. As cartas dos que se matavam eram publicadas nos jornais, permitindo aos leitores ver o evento do ponto de vista dos atores, sendo que essas cartas, por sua vez, influenciavam o estilo de outras deixadas por suicidas posteriores."

Aqui, mais que simplesmente relatar os argumentos de cada personagem, tratava-se de dar a ele sua própria voz e o direito à autoria da própria história. Entramos, portanto, na questão da temática da privacidade e/ou intimidade.

\footnotetext{
${ }^{75} \mathrm{O}$ autor se refere a Walter Benjamin e sua obra.
} 
Na história da imprensa brasileira, o Correio Brasiliense é considerado o primeiro jornal impresso do país, embora fosse redigido e impresso em Londres. Seu número inaugural foi lançado em $1^{\circ}$ de Junho de 1808. Sua temática era ligada às questões nacionais. No entanto, poucos meses depois (setembro de 1808) foi lançada a Gazeta do Rio do Janeiro, jornal oficial, impresso na Imprensa oficial. Aqui, a temática da vida privada, ainda que não do homem comum, já se apresentava: o jornal falava do estado de saúde dos príncipes europeus, natalícios e odes da família real, ao lado de algumas notícias sobre o cotidiano da corte (SODRÉ, 1966, p.23-5).

Já no século $\mathrm{XX}$, essa temática voltada ao relato da chamada "vida social" permanece em voga:

"As chamadas informações sociais - aniversários, casamentos, festas - aparecem em linguagem melosa e misturam-se com a correspondência de namorado, doestos a desafetos pessoais e a torva catilinária dos a pedidos." (SODRÉ, 1966, p. 323, grifos do autor)

A questão da narrativa da vida das pessoas célebres, ainda que não feita pelo próprio público aparece também nos Almanaques, que surgem no país ainda no início do século XIX, reunindo literatura, informações e publicidade. O primeiro registro é de 1808, com o Almanaque da Vila de Porto Alegre. Mas, entre os mais importantes, destacam-se a Folhinha do Ano Bisexto de 1840 e o Anuário da Província do Rio Grande do Sul, de 1885. Este último reunia poesias, contos, biografias, aspectos do céu, calendários, charadas etc. e foi rebatizado em 1892 como Almanaque do Estado, circulando até 1914 (SODRÉ, 1966, p.2778).

Mas ainda que sejam divulgados fatos da vida íntima das celebridades quer nas colunas sociais da época, quer nas 
biografias, é nos espaços literários que os diários pessoais buscarão seus melhores espaços de veiculação.

É bem verdade que o fenômeno dos diários pessoais tem uma íntima relação com a mídia impressa. O próprio termo diário tem em suas definições jornal (e vice-versa):

“...desde o momento de sua cunhagem, entretanto, o termo diário parece ter estado sempre próximo do sinônimo exato para jornal, representando uma recordação diária ou regular de eventos públicos e privados." (GANNETT, 1992, p. 106-7, grifos da autora)

Também os dicionários apontam esse sinônimo entre os dois vocábulos e oferecem ao termo diarista o significado de ser um "redator de jornal diário" (MINIAURELIO, 2004, p. 316), ou seja, o mesmo sentido que se dá hoje para uma das funções dos jornalistas.

No entanto, o espaço destinado a esse tipo de escrito nos veículos de mídia impressa sempre foi reduzido e ligado, principalmente, aos suplementos literários, parte pela vinculação dos diários às categorias literárias que incluem também as autobiografias, apesar das grandes diferenças entre eles ${ }^{76}$.

É claro que o objetivo inicial destes relatos não é a publicação em mídia impressa: mesmo considerando que o autor, ao fazê-lo, pretendia em algum momento que ele fosse público, não há porque acreditar que seu foco seria nos periódicos jornalísticos. É mais provável que o autor pensasse numa estruturação literária, com a publicação em forma de livro.

\footnotetext{
${ }^{76}$ LEJ EUNE (1986, p. 50-2) apresenta como uma das principais características da autobiografia (e que a diferencia dos outros gêneros de narração pessoal, como o diário), a temporalidade. Se o diário prende-se ao momento atual, registrando os fatos do dia-a-dia de acordo com que eles vão acontecendo, a autobiografia debruça-se sobre o passado para construir sua narrativa. Trata-se de uma narrativa retrospectiva.
} 
Mesmo assim, vários veículos de imprensa abriram espaço para publicar trechos de diários descobertos, ainda que essas publicações não se tornassem regulares.

Ao lado dessas iniciativas, podemos registrar também a publicação de outros textos literários enviados pelos leitores (crônicas e poesias, em sua maioria) e escritores renomados. Essa linha editorial é percebida, principalmente, no jornalismo francês que tem em sua origem a influência das esferas tradicionais da Política e da Literatura (FERENCZI, 1993, p.19-42).

Com a expansão do estilo de jornalismo anglo-americano, estes espaços são cada vez mais reduzidos e mais separados do contexto geral da publicação:

"A América possuía melhores condições para aí ter emergido mais rapidamente um discurso jornalístico próprio porque os seus escritores não conseguiram impor aos jornalistas os valores e normas literárias. Nos Estados Unidos e em Inglaterra, a imprensa cresceu independentemente do campo literário, mas isso não aconteceu em França, onde a emergência do campo jornalístico foi uma longa luta pela independência, não só face à esfera política mas também face ao campo literário." (CHALABY, 2006)

No entanto, é no jornalismo americano que tem origem a corrente jornalística que mais espaço abre para a narrativa de histórias pessoais, a partir da construção de personagens: o jornalismo literário.

Surgido no século $X X$ e com seu principal marco nos Estados Unidos dos anos 60 (com o New J ournalism que teve como um de seus principais expoentes Tom Wolfe), o J ornalismo Literário apresenta-se como uma alternativa ao modelo jornalístico estabelecido a partir da sociedade industrial.

“(...) o novo modo de narrar os fatos consistia em uma retomada, na literatura americana, de técnicas esquecidas do realismo dos tempos de Richardson e 
Dickens. Não só desse tipo de realismo que 'mobilizava os leitores', mas daquele que, na literatura americana dos anos 30, acompanhou a Depressão nos Estados Unidos." (RESENDE, 2002, p. 21, grifos do autor)

Trata-se de um modelo em que há a utilização de ferramentas da narrativa ficcional (como, por exemplo, a descrição minuciosa de cenas e cenários ou a construção de diálogos) no discurso jornalístico, como explica Bruno SANTOS (2005, p. 4, grifos do autor):

"(...) o New Journalism se caracterizou pela incorporação de recursos literários ao costumeiro trabalho de apuração e registro jornalísticos, num questionamento do método tradicional de reportagem de fatos. As ferramentas tomadas de empréstimo à literatura - em especial ao realismo social europeu do século XIX - tinham como objetivo conferir maior vivacidade aos relatos. De acordo com Tom Wolfe, um dos principais expoentes do 'movimento', elas eram principalmente quatro: a construção cena a cena, a utilização de símbolos de status, o uso de diálogos e o emprego de pontos de vista."

No entanto, como frisa RESENDE (2002, p. 21), o resultado é "um texto que prima não pela unidade, mas, antes, por uma pluralidade de focos, linguagens, personagens, enfim, um texto permeado por verdades factuais e ficcionais".

Esse modelo (do jornalismo literário) é um dos que mais marcam as narrativas de histórias pessoais na mídia impressa, principalmente no que se refere à utilização de técnicas de construção de personagens.

É interessante notar que esse modelo requer um grau forte de autoria por parte do profissional de comunicação que irá narrar a história. É através do repertório desse profissional (seus conhecimentos do assunto e sua capacidade de relacioná-los a outros universos e também de fornecer novas interpretações e 
contextualizações para os fatos) que o tema (e as histórias pessoais narradas dentro dele) será desenvolvido.

No entanto, são os próprios elementos tomados de empréstimo à narrativa ficcional que enriquecem a construção do texto do jornalismo literário e, ao mesmo tempo, levam à desconfiança de parte das redações jornalísticas acerca de sua veracidade.

SANTORO (2004, p. 47-8) destaca que a desconfiança quanto ao jornalismo literário é quase generalizada nas redações norte-americanas. O próprio livro-reportagem A Sangue Frio, de Truman Capote (considerado um dos clássicos do New Journalism) recebe críticas e acusações de falta de fidelidade ao real nos diálogos apresentados.

Mas é importante destacar que não só o jornalismo literário utiliza técnicas ficcionais na narrativa jornalística. Estes elementos estão presentes em várias outras propostas desenvolvidas pela imprensa.

Nas revistas (e em particular nas revistas femininas), é comum o desenvolvimento de seções para a divulgação de histórias vividas por leitores. São espaços que privilegiam os relatos enviados pelo público e que possuem apelo (quanto à temática/experiência vivida) junto aos demais leitores, o que representa a primeira ação dos profissionais de comunicação sobre a narrativa original: a seleção editorial. E, embora haja o relato inicial enviado pelo leitor, é facilmente perceptível que o produto final divulgado é fruto de um tratamento editorial que adequa o texto à linguagem adotada pelo veículo. Muito diferente da tradicional seção de cartas em que o texto do leitor é mantido quase exatamente como o original, sofrendo apenas cortes para adequar seu tamanho ao limite de linhas permitido. No entanto, 
nestas histórias, podemos também identificar variadas ferramentas da narrativa ficcional.

Esse maior número de experiências de relatos pessoais do próprio público nas revistas femininas brasileiras (e na imprensa feminina ocidental em geral) é reflexo da vinculação ao jornalismo interpretativo adotado por esses veículos, com uma linha "mais para o diversional, o opinativo, o jornalismo de serviço." (BUITONI, 1981, p. 2)

O primeiro periódico feminino, o Lady's Mercury, editado na Grã-Bretanha em 1693, já apresentava um consultório sentimental. Nos Estados Unidos, o mais conhecido foi o Ladies'Magazine, de 1828, que reunia entretenimento, esclarecimento e serviço.

No Brasil, a imprensa feminina começa no século XIX, com um destaque para os conteúdos de literatura e moda. Acredita-se que o primeiro periódico feminino brasileiro foi $\mathrm{O}$ Espelho Diamantino, de 1827 (BUITONI, 1981, p. 10-2).

Mas a participação de leitoras vai se tornar um destaque com a Revista Feminina, publicada de 1914 a 1935 e que chegou a alcançar a tiragem de 30 mil exemplares:

"A 'Revista Feminina' pode ser considerada como precursora dos modernos veículos dedicados à mulher. $\mathrm{Na}$ 'Revista Feminina' havia até estreito intercâmbio com as leitoras a demonstrar sua vitalidade como produto editorial mais 'moderno', que abre espaço para uma resposta que sempre redunda em capitalização de mais simpatias." (BUITONI, 1981, p. 41, grifos da autora)

Em outra experiência, A Cigarra (de 1924) mantinha a seção "Colaboração das leitoras", que podia ser definida como:

“...espelho da movimentada participação das leitoras em suas páginas, que traziam recados de moças enamoradas a príncipes encantados, fofocas 
entre colegas da escola, comentários a moças que estiveram em bailes, com expressiva presença de endereços do interior. A seção era uma espécie de 'cotillon', de comunicação adolescente girando em torno de namoros e 'footings' em praças e se estendia por várias páginas. No início dessa seção, havia de quando em quando, alguns debates um pouco mais sérios". (BUITONI, 1981, p. 49, grifos da autora)

Na mesma linha, em 1947, surge Grande Hotel, com relatos "verídicos" e seção de cartas, inspirado na francesa Confidences (1938), que:

“...trazia relatos 'verdadeiros' de problemas sentimentais, tornando-se um dos maiores sucessos editoriais da época, ultrapassando desde logo um milhão de exemplares semanais." (BUITONI, 1981, p. 77, grifos da autora)

A temática da vida privada prossegue durante a segunda metade do século XX. A Revista do Rádio, por exemplo, é um marco dos anos 50 na questão da abordagem da vida privada, pois é especializada em falar da vida dos artistas.

“O conteúdo da Revista do Rádio prende-se a temas relacionados ao ideal de amor romântico burguês, tais como 'lares felizes' (bons casamentos), a vida familiar dos artistas, fofocas, romances, rompimentos amorosos." (BASSANEZI, 1996, p. 33-4, grifos da autora)

Nos anos 60, o destaque será a revista Claudia, por ter introduzido no país o modelo "magazine moderno" feminino. A revista surgiu em 1961 e circula até hoje. Em 1963, passou a publicar os artigos de Carmem da Silva com conselhos para as leitoras baseados na psicologia. Os artigos, considerados feministas, geraram muita polêmica à época.

Na questão da participação do público, Claudia estabelece uma conversa com as leitoras através do "Claudia responde", onde oferece conselhos sobre os dramas/dúvidas das leitoras: 
“Existe também um certo 'diálogo' entre a revista e as leitoras (e leitores), através da seção de cartas, que dá uma idéia das expectativas do público e da repercussão de alguns artigos (principalmente os mais polêmicos)." (BASSANEZI, 1996, p. 39, grifos da autora)

\section{a. Mídia I mpressa e Histórias Pessoais em 2007}

Se, desde seu início, os jornais abriram espaços para a participação dos leitores através das seções de cartas, ao longo da evolução desses Meios, muito pouca coisa mudou. Assim, o espaço tradicional para o público tomar parte da mídia impressa (tanto em jornais quanto em revistas) ainda é a seção de cartas.

Acompanhando a circulação dos veículos impressos brasileiros $^{77}$, notamos que entre os dez veículos de maior circulação, apenas dois são jornais (Extra e Folha de S. Paulo); entre os quinze maiores, apenas quatro (acrescentamos aos dois anteriores, O Globo e O Estado de S. Paulo); e entre os vinte, apenas cinco (mais Meia Hora):

\begin{tabular}{|l|l|c|c|}
\hline Posição & \multicolumn{1}{|c|}{ Publicação } & $\begin{array}{c}\text { Part. Mercado } \\
\%\end{array}$ & $\begin{array}{c}\text { Média } \\
\text { Circulação }\end{array}$ \\
\hline 1 을 & Veja & 5,86 & 1.100 .976 \\
\hline 20 & Época & 2,26 & 424.683 \\
\hline 3o & Nova Escola & 2,19 & 410.560 \\
\hline 4o & Cláudia & 2,10 & 395.078 \\
\hline
\end{tabular}

77 Dados do IVC - Instituto de Verificação de Circulação referentes aos primeiro semestre de 2007. 


\begin{tabular}{|c|c|c|c|}
\hline 50 & Seleções do Reader's Digest & 2,09 & 393.078 \\
\hline 60 & Veja São Paulo & 1,86 & 349.259 \\
\hline 70 & Isto É & 1,85 & 346.704 \\
\hline 80 & Superinteressante & 1,79 & 335.231 \\
\hline 9은 & Extra & 1,68 & 315.964 \\
\hline 10 은 & Folha de S. Paulo & 1,60 & 299.761 \\
\hline 11 은 & Caras & 1,59 & 299.349 \\
\hline $12 \%$ & O Globo & 1,47 & 275.141 \\
\hline $13 \%$ & O Estado de S. Paulo & 1,27 & 238.122 \\
\hline 140 & Nova & 1,20 & 225.938 \\
\hline $15^{\circ}$ 인 & Manequim & 1,09 & 203.852 \\
\hline 160 & Meia Hora & 1,05 & 197.716 \\
\hline 17 음 & Playboy & 1,03 & 192.647 \\
\hline $18^{\circ}$ & Revista MONET & 1,00 & 188.109 \\
\hline 19 은 & Boa Forma & 0,99 & 185.888 \\
\hline 20 은 & Marie Claire & 0,97 & 182.030 \\
\hline
\end{tabular}

Acompanhando de maneira sistemática ${ }^{78}$ os quatro jornais de maior circulação no país (Extra, Folha de S. Paulo, O Globo e O Estado de S. Paulo - conforme dados apresentados) ${ }^{79}$, notamos que existem poucas diferenças no tratamento que todos oferecem aos conteúdos de seu público bem como ao espaço para histórias pessoais. O maior espaço concedido aos leitores ainda é mesmo a tradicional seção de cartas que, no entanto, na média, não ultrapassa um terço de página do jornal e, pelos índices

\footnotetext{
${ }^{78}$ Os jornais foram acompanhados no período de 16 a 29/09/07.

79 O quinto jornal de maior audiência "Meia Hora", foi excluído da análise conforme explicado na Parte I - Sobre a Tese, Capítulo 2. Metodologia, à p. 44.
} 
apresentados $^{80}$, seleciona bem pouco material do muito que é recebido. Trata-se de um espaço, basicamente, para opinião, com poucas manifestações de histórias pessoais. Estas, quando existem, em geral são narrativas de experiências que podem legitimar a opinião defendida.

As histórias pessoais que merecem destaque são as das celebridades e ainda assim não são narradas por elas, mas por meio dos repórteres. Os anônimos aparecem como personagens no meio das reportagens e raramente têm sua história em primeira pessoa. A fórmula de entrevistas com perguntas e respostas é muito utilizada. Os depoimentos em primeira pessoa não são tão freqüentes e quando aparecem, em geral, são separados em um box.

Mesmo nos suplementos voltados a públicos mais acostumados a ferramentas de interatividade, como adolescentes e crianças (que já convivem com a interação das Novas Tecnologias desde seu nascimento), a abordagem desses jornais é absolutamente tradicional, tanto nos espaços que oferecem às contribuições dos leitores quanto no tratamento que dispensam às histórias pessoais.

Apesar dos espaços restritos, é possível observar a formação de uma comunidade de leitores que poderia ser comparada (guardadas as devidas proporções) às comunidades dos cafés da Inglaterra do século XVIII. É comum um leitor se referir ao comentário ou opinião de outro leitor publicada anteriormente sobre determinado assunto. Mas não há um prosseguimento do debate. Os jornais não criam espaços para que essa discussão ou

\footnotetext{
${ }^{80}$ Ver informação sobre os índices divulgados pela "Folha de S. Paulo" na página
} 138. 
confronto de idéias e posições cresça e envolva os demais leitores (inclusive aqueles que não acompanham a seção de cartas).

Essa relação com o jornal e seu sentimento de apropriação do veículo pode ser percebida na correspondência publicada pelo O Estado de S. Paulo do dia 23/09/07, onde um leitor questiona qual é o verdadeiro influenciador na relação jornalpúblico:

"Muros das lamentações: é o Estadão que doutrina os seus leitores ou são eles que direcionam o jornal?" (FERREIRA, 2007, p. A3, grifos da publicação)

Entretanto, a fórmula Opinião na Seção de Cartas + Dúvidas respondidas por especialistas + Reclamações encaminhadas aos órgãos competentes é a que impera nos nossos principais jornais.

No conteúdo dos jornais, podem ser encontradas poucas temáticas relativas a narrativas da vida pessoal e quando aparecem, geralmente estão dentro de um contexto geral de matéria/temática não tendo sido uma contribuição do próprio público. E, mesmo assim, não são vistas com freqüência. Mesmo assuntos que possibilitariam (e seriam enriquecidos com) a utilização de narrativas das experiências de vida do próprio público costumam ser conduzidas sem essa vertente.

O jornal de maior circulação no país, Extra, é o que mais destoa do grupo, apresentando alguns espaços mais diferenciados para o público, muito em função de ser o mais popular dos quatro $^{81}$. Assim, é possível encontrar chamadas para dramas pessoais de pessoas comuns na primeira página, embora não sejam narrados pelo próprio autor e sim pelos repórteres.

\footnotetext{
${ }^{81}$ É o que custa mais barato e tem o menor número de páginas e cadernos. Sua
} linguagem e temáticas também são mais voltadas para as classes populares. 
O recurso do depoimento em primeira pessoa, com o público contando sua própria história nas páginas do jornal é muito pouco utilizado ${ }^{82}$ e quando aparece vem como Box de uma matéria mais ampla. Em geral, os depoimentos sofrem algum tratamento por parte do repórter já que o vocabulário e as construções da narrativa nem sempre correspondem ao que habitualmente é encontrado junto a grupos do extrato social representado - as classes mais baixas.

O jornal destina um bom espaço para os dramas pessoais de seu próprio público: das matérias enfocando um caso de mau atendimento em hospitais até o desaparecimento de pessoas. Aliás, nesta questão, o jornal mantém um espaço diário em que publica o desaparecimento de alguma pessoa (adultos e crianças) com foto, texto e local para onde podem ser enviadas informações ${ }^{83}$.

O principal espaço para o público de Extra é sua página 2 que recebe o título de "Você manda". A página reúne uma série de seções e remete sempre ao site onde é possível participar e ter acesso a outros materiais. Há referências a questões que são objeto de Enquetes e Fóruns diários. Às segundas-feiras é divulgado o entrevistado (uma celebridade em geral do mundo artístico) da próxima semana da seção "Você Entrevista" publicada no Caderno "Sessão Extra". A seção divulga as perguntas que foram mais freqüentes nas mensagens dos leitores mas sem informar o nome deles.

Na mesma página 2 está a seção "Eu Repórter", que traz texto e foto enviados por um leitor que aqui sim tem seu nome publicado em destaque como o de um jornalista que assinasse a

\footnotetext{
${ }^{82}$ Embora em relação aos demais jornais analisados mereça destaque.

${ }^{83}$ Essa experiência foi muito bem sucedida no jornal Notícias Populares, nos anos 70/80, que publicava esse material em suas edições.
} 
matéria. As temáticas são quase totalmente sobre problemas das cidades: buracos, falta d'água, bueiros entupidos, abandono de praças, bairros.

A página abriga ainda duas seções de cartas: "Opinião" que traz diversas contribuições sobre assuntos que são tema do Fórum e também de matérias do jornal; e "Carta Branca", um espaço de reclamações/dúvidas que tem temáticas específicas em cada dia da semana (Consumidor, Lei Trabalhista, Comunidade, Servidor e INSS). A seção, em geral, publica a mensagem do leitor e a resposta da empresa/órgão correspondente.

É interessante notar que o acesso às diversas seções desta página é feito por e-mail ou acesso à página do Extra ${ }^{84}$. Não é oferecida ao público a opção de mandar esses mesmos materiais (contribuições, dúvidas, reclamações) por outros meios como cartas ou faxes.

O jornal, aliás, anuncia bastante a oferta de outros materiais como fotos, vídeos, áudios etc. no site e aceita contribuições dos leitores.

Também a fórmula do espaço para tirar dúvidas aparece em Extra: a coluna "Consultório", publicada de segunda a sábado, traz questões dos leitores (com identificação) respondidas por profissionais de saúde; "Sexologia", publicada aos domingos no suplemento "Bem-viver extra", traz dúvidas dos leitores respondidas pelo sexólogo Arnaldo Risman e na coluna "Jogo de Cintura".

Além disso, o caderno "Sessão Extra", publicado de segunda a quinta-feira e aos sábados traz a seção "Repórter Amador" com novas contribuições de seu público. No entanto, não

${ }^{84}$ http://extra.globo.com/ 
é utilizada na narrativa a primeira pessoa, sendo adotada a fórmula de "O leitor fulano diz que...".

É importante ressaltar que em vários desses espaços a participação é restrita a cartas, em oposição ao que é feito com a segunda página ("Você Manda"). Não há o costume de abrir várias possibilidades de participação para o público do periódico.

Já a Folha de S. Paulo traz, diariamente, uma coluna fixa para leitores, o "Painel do Leitor", que é publicada na página 3 do primeiro caderno (A3), ocupando cerca de um terço da página e estando ao lado de "Tendências/Debates" (seção de artigos encomendados/recebidos pelo jornal) e acima do "Erramos" (seção de retificação de informações erradas publicadas na edição anterior). Em geral, reúne opiniões dos leitores sobre matérias do jornal e sobre assuntos que são notícia. Às vezes, a mensagem é publicada com resposta da Redação. Os leitores são identificados pelo nome completo (nome mais sobrenome) e pela cidade de onde são. No Domingo, é publicado um índice com o número de correspondências recebidas e um ranking dos assuntos mais abordados por elas. Pelo número de mensagens que o jornal informa ter recebido e o acompanhamento feito na semana, evidentemente há seleção do material publicado - menos de $15 \%$ do que é recebido encontra espaço na seção.

No caderno Cotidiano, há a coluna "Consumo", que não é diária e traz reclamações dos leitores, mas em texto elaborado pela redação (modelo: "O leitor fulano de tal afirma que...."). As reclamações são acompanhadas pela resposta da empresa da qual se está reclamando.

No suplemento "Equilíbrio", publicado às quintas-feiras, o público tem suas dúvidas respondidas por especialistas em 
"Pergunte Aqui" e pode publicar suas opiniões (em geral sobre as matérias do próprio suplemente) em "Correio".

Nos suplementos, a estrutura de uma seção de cartas como principal espaço é mantida. A "Folhinha", publicada aos sábados, traz o "Mural", espaço para desenhos e mensagens dos leitores, com cerca de um terço de página. Em "Folhateen", a "Seção de Cartas" ocupa cerca de meia página. Em geral, falam das matérias do caderno ou de assuntos abordados por elas. Também há referências a opiniões de outros leitores. Além disso, "Folhateen" traz a coluna "Sexo \& Saúde", de Jairo Bouer, com uma pergunta enviada por um leitor e respondida por ele.

Mas é a "Revista da Folha", publicada aos domingos, que traz mais espaços para as mensagens/histórias dos leitores. A Coluna "Fale com ela", de Luciana Saddi, por exemplo, traz uma questão enviada por leitores (não identificados) e resposta elaborada pela colunista. "Barbara responde" é a coluna de Barbara Gancia com várias mensagens de leitores respondidas em tom de humor. Na mesma página (a última), está a coluna "Curtas Cartas", com mensagens dos leitores - em geral, comentando as matérias da própria Revista.

A grande inovação da "Folha", no espaço destinado às histórias pessoais do público comum, vem de outra seção da "Revista da Folha": "Bichos". A seção traz um espaço intitulado "Do Leitor", com publicação de uma história de um animal de estimação narrada em primeira pessoa por seu dono, inclusive com foto do animal (de autoria também do dono). O crédito pela autoria aparece no texto e na foto. A seção, inclusive, mantém desde 2005 um concurso de fotos de animais de estimação para o calendário do ano seguinte distribuído pelo jornal. Os leitores enviam as fotos 
de seus animais ${ }^{85}$ e a equipe da "Revista" faz a seleção de doze que ilustrarão os meses do calendário de mesa.

No corpo do jornal, as histórias pessoais ocupam pouco espaço e quando aparecem estão ligadas, em geral, a celebridades e em formato de entrevista de pergunta e resposta ou no texto dos repórteres. Os depoimentos são raros: na semana analisada (17 a $23 / 09 / 07)$, os melhores exemplos de depoimentos em primeira pessoa sobre experiências pessoais aparece na matéria "83\% os fumantes dizem que gostariam de parar" (FOLHA DE S. PAULO, 2007, p. C-9, 17, 18 e 19), ainda que os autores não sejam anônimos (um é secretário-assistente de redação da própria Folha e a outra é editora do programa Vitrine, da TV Cultura) e que seus relatos apareçam como box da reportagem.

No entanto, a Folha mantém uma das poucas colunas da imprensa brasileira a se utilizar da ficção propriamente dita (e não apenas de seus elementos narrativos) dentro do jornalismo: a coluna de Moacyr Scliar, publicada às segundas-feiras no caderno "Cotidiano" traz um relato ficcional em cima de uma notícia real publicada pelo próprio jornal.

O Globo é, dos quatro jornais, o que se aproxima mais da tentativa de um espaço para seus leitores anônimos contarem suas histórias pessoais ao mesmo tempo em que é o que oferece menos espaços (em número) de participação e de utilização de histórias pessoais.

Nas colunas de "Ancelmo Gois" há quase que diariamente fotos encaminhadas pelos leitores. São flagrantes da cidade, vistos de maneira intimista. E os próprios leitores reagem a

\footnotetext{
${ }^{85}$ No primeiro ano (2005 - calendário de 2006), os leitores podiam enviar fotos de quaisquer animais de estimação. No segundo (2006 - calendário de 2007), o concurso restringiu a participação para fotos de gatos e cães - o calendário publicado trouxe o patrocínio de ração para cães e gatos.
} 
fotos publicadas de outros leitores iniciando um diálogo fotográfico. Na semana de 17 a 23 de setembro de 2007, por exemplo, o assunto eram as flores que surgiam nas diversas regiões. A partir de uma foto dessas enviada por um leitor, várias outras manifestações surgiram e algumas foram selecionadas para publicação. Os temas não são estimulados, partem do próprio público. Na semana em questão, as flores (de várias espécies) conviveram com o protesto de dois leitores pela não cassação do Senador Renan Calheiros.

A coluna "Gente Boa", de Joaquim Ferreira dos Santos, publicada no "Segundo Caderno" desenvolve um trabalho parecido, abrindo espaço para os leitores publicarem fotos e informações de pessoas anônimas, consideradas por eles como Gente Boa. Tal qual na coluna de "Ancelmo Gois", o espaço não é diário.

O espaço principal de mensagens também é o maior entre os jornais analisados, ocupando dois terços de uma página, ao lado dos artigos publicados no jornal. A seção "Carta dos Leitores" traz, em geral, a opinião sobre os assuntos que estão em foco nos noticiários mas é comum que os leitores contem histórias/experiências pessoais para falar de assuntos como violência, acidentes no trânsito, abandono da cidade etc.. Os leitores podem participar por carta, fax, e-mail ou através do site ${ }^{86}$.

Além desta seção principal, cartas são publicadas também na coluna "Mala Direta", dentro da página "Defesa do Consumidor", às quartas-feiras e domingos (com reclamações seguidas de respostas das empresas citadas); na seção "Qual é o seu problema?", aos domingos (com respostas de especialistas de áreas diversas - saúde, direito etc - às consultas do público); e na

\footnotetext{
${ }^{86}$ www.oglobo.com.br
} 
"Revista", aos domingos (em geral sobre as matérias do próprio suplemento).

Os leitores aparecem ainda na coluna de Paulo Coelho (que publica opiniões enviadas a seu blog sobre um determinado assunto proposto) e de Roberto Zentgraf, "Dinheiro em caixa" (neste caso os nomes dos leitores não aparecem, apenas as informações que seriam oferecidas em função dos temas e dúvidas apresentadas pelo público).

Para o público infantil, o suplemento "Globinho" traz três quartos de página com desenhos e textos de seus leitores. $\mathrm{Na}$ mesma página, anuncia-se a enquete (feita através do site) para que o público escolha a matéria da capa da próxima edição.

Em relação à temática, há muito pouco de histórias pessoais em todo o jornal. Os depoimentos em primeira pessoa são praticamente inexistentes fora das tradicionais aspas no texto do repórter e quando existem são de celebridades. Como exemplo, podemos citar a matéria "O fim da paz na via expressa" (COSTA, Ana Cláudia, 2007, p. 15) publicada na edição de 19/09/07, mostrando a foto de um rapaz abandonando o carro e fugindo de um tiroteio na Linha Vermelha acompanhada de texto em que a repórter narra o que aconteceu. $O$ depoimento do rapaz fotografado aparece apenas ao longo da matéria, entremeado ao texto da repórter e, muitas vezes, na voz desta.

Em O Estado de S. Paulo, há duas seções fixas diárias para materiais enviados pelos leitores: a Seção "Forum dos Leitores" e "São Paulo Reclama".

A seção "Fórum dos Leitores" ocupa a parte inferior das páginas 2 e 3 do Primeiro Caderno ( $\mathrm{A} 2$ e A3). A coluna fica abaixo dos artigos assinados (página $A 2$ ) e dos Editoriais do jornal (A3). $O$ espaço ocupado corresponde a cerca de um terço de página. Em 
geral, traz opiniões do público acerca dos assuntos que estão sendo notícia na época. Visivelmente as mensagens/cartas são editadas porque algumas não passam de uma frase. As críticas ao jornal geralmente são respondidas.

A seção "São Paulo Reclama" é publicada no caderno Cidades/Metrópole. São reclamações referentes a serviços, condições da cidade e as mensagens são publicadas junto com a resposta do órgão competente. Às vezes, há também uma tréplica do leitor reclamante.

Além das duas seções fixas, há outros espaços ligados a suplementos semanais. No "Estadinho", publicado aos sábados, “O Espaço é seu!" reúne desenhos dos leitores. A seção ocupa uma página inteira. Mesmo voltado para um público que já nasceu com a internet e sob o signo da interatividade, isso é tudo que o suplemento oferece em termos de participação.

No "Suplemento Feminino" às vezes aparecem matérias formadas por depoimentos de anônimos, em primeira pessoa, porém a matéria é assinada pelo jornalista que costura os textos.

Em "TV \& Lazer", a coluna “Descontrole remoto", de Mário Viana, chama os leitores a opinarem e publica a seleção de respostas (com os nomes dos leitores, ainda que não completos). Já a Coluna "Fiscal da TV paga", de Roberto Godoy, também publica trechos das opiniões dos leitores, mas sem sua identificação.

As referências às histórias pessoais vêm apenas dentro de matérias e narradas pelo repórter - o público é personagem, não autor. Há utilização de elementos da narrativa ficcional (o principal deles é o diálogo). Raramente utiliza-se a narrativa em primeira pessoa para as histórias dos personagens e, quando isso acontece, vem num box, separado do texto principal. Os 
depoimentos parecem editados. O personagem usa a primeira pessoa com mais freqüência quando a entrevista é publicada na forma de pergunta e resposta.

As revistas, tais quais os jornais, ainda têm na seção de cartas seu principal espaço, embora já apresentem experiências diferenciadas com histórias pessoais do público. Na própria seção de cartas, é possível notar o estabelecimento de um maior diálogo entre os veículos e seu público.

Outra característica comum nas revistas atuais é a destinação de espaços em sua edição impressa para os conteúdos dos sites. E aí podemos diferenciar dois grandes grupos: um preocupado em fornecer, online, conteúdos complementares ou diferenciais da versão impressa, e outro preocupado em criar online um espaço de interação que, inclusive, represente uma maior participação do público na produção do veículo.

Entre as revistas, Veja não só ocupa a primeira posição entre os veículos de mídia impressa de maior circulação como seu suplemento regional paulista, a Veja SP fica em sexto lugar. Sua periodicidade é semanal.

Se, para efeitos de medição da circulação, essa divisão é importante (tal qual é feito também com a Folha de $\mathrm{S}$. Paulo e a Revista da Folha), para nosso estudo é melhor avaliá-las conjuntamente já que o público não pode adquiri-las separadamente.

O principal espaço destinado por Veja ao seu público é a seção "Cartas" que ocupa o espaço de mais de quatro páginas da revista ${ }^{87}$. Além das correspondências, agrupadas por assunto, Veja

\footnotetext{
${ }^{87}$ As colunas com as mensagens são espalhadas num número maior de páginas que o citado, já que em cada uma dividem espaço com publicidade. O cálculo do 
coloca neste espaço sua participação, iniciando um diálogo com os leitores. Há, por exemplo, uma avaliação geral das cartas da semana, em que várias opiniões sobre um determinado assunto são costuradas num texto de análise elaborado pela redação. A revista apresenta, em todas as edições, um quadro resumo das correspondências, com o número de mensagens recebidas, o tipo de encaminhamento (e-mail, cartas ou fax) e o ranking dos assuntos mais comentados.

No entanto, o próprio formato adotado limita a possibilidade de encontrarmos substancialmente narrativas de histórias pessoais do público. Quando alguma correspondência recebe destaque na seção, ela deixa de ser um depoimento direto e aparece como trechos em aspas dentro da narrativa de um texto elaborado pela Revista. Um bom exemplo é o box "Pobre Dinamarca" (2007, p. 34) em que o que seria uma excelente narrativa do leitor Maurício Lopes acerca de sua experiência nas comemorações do 7 de Setembro na Embaixada brasileira em Copenhague, acaba como um relato da revista, com falas do leitor entre aspas. É como se, para ter destaque dentro da seção, o leitor precisasse perder sua autoria e passar a ser narrado pelo veículo.

Veja São Paulo (ou Vejinha), suplemento regional da Veja, a acompanha na filosofia, tendo como principal espaço para o público a seção "A Opinião do Leitor", com cerca de duas páginas. Tal qual em Veja, há o índice dos assuntos mais comentados e boxes com destaques de opiniões sobre um determinado assunto costurados em texto da revista.

E, embora entre as três revistas (Veja, Época e Isto É) voltadas a informações gerais, Veja seja a que dá maior espaço 
para a seção de cartas, a participação do público da revista fica restrita a essa seção.

Já Época semanalmente traz, nas pouco mais de duas páginas da seção "Caixa Postal", alguns espaços mais diferenciados para seus leitores. Em primeiro lugar, a correspondência escolhida como "Carta da Semana" é publicada em destaque das demais, sem que o texto saia da primeira pessoa. Há também um box com respostas a uma questão feita pelo site: "A voz rouca das ruas". A seleção, no entanto, não divulga os nomes dos autores dos comentários. "Caixa Postal" traz ainda um índice das reportagens da revista mais comentadas pelos leitores.

A revista utiliza seu site $^{88}$ como um espaço para o público "participar" da publicação e busca incentivar essa participação através de uma página intitulada "EPOCA.com.br". A estratégia de Época em relação ao seu site e a divulgação dele no veículo impresso é oposta à adotada por Veja, que também publica a página "Veja.com" em sua edição impressa. A preocupação de Veja não é a de estabelecer possibilidades de participação do público e sim oferecer conteúdos diferenciados, a mais do que o que se encontra na revista.

Em "EPOCA.com.br", encontram-se chamadas para votações e enquetes propostas pelo veículo e cujo resultado é publicado na semana seguinte. Há também o "Blog da semana", em que os leitores são convidados a dar opinião sobre um tema. Uma seleção dos depoimentos é publicada junto com a matéria sobre a temática na semana seguinte.

A revista mantém, também através do site, uma seção destinada a que o público participe de entrevistas com personalidades. Intitulada "Você é o repórter", abre espaço no site 
para que o público envie perguntas a entrevistados prédeterminados pelo veículo que seleciona as melhores e as leva até o entrevistado. As entrevistas são publicadas, quinzenalmente, no site e na própria revista.

Além disso, a coluna "Nossa Carreira", de Max Gehringer, traz dúvidas de leitores respondidas pelo colunista, ainda que sem identificação completa do leitor (apenas o nome, sem sobrenome ou localidade).

Época oferece ainda espaços para perfis, ainda que de celebridades e sempre na narração dos repórteres.

Já Isto É, também semanal, é a que apresenta os espaços mais restritos: tudo se resume à sua seção "Cartas" que não chega a ocupar duas páginas da revista. As mensagens são agrupadas por assunto, mas não há destaque entre elas, comentários por parte da redação ou índices que mostrem o volume das cartas, temas de maior interesse etc. Trata-se de um modelo tradicional, em que a seção parece descolada do restante da publicação sem nenhum efeito dialógico.

Nova Escola, a segunda colocada em circulação nacional, tem periodicidade mensal e também limita a participação do público à sua seção "Cartas" que ocupa cerca de duas páginas de cada edição. O espaço é compartilhado com "Correções", associação, aliás, que é feita em grande parte dos veículos impressos pesquisados.

As cartas são, em quase sua totalidade, a respeito das matérias da revista e uma delas merece destaque gráfico a cada edição.

As matérias de Nova Escola muitas vezes trazem depoimentos em primeira pessoa (em geral de alunos e 
educadores), mas sempre relacionados a uma matéria sobre uma temática determinada. Em geral, na matéria principal estão os depoimentos mais longos e que recebem maior destaque.

Em Superinteressante, de periodicidade mensal, a seção de cartas é intitulada "Desabafa - solte o verbo" e ocupa cerca de três páginas a cada edição. Além dos textos, traz, às vezes, charges e ilustrações dos leitores. Apresenta também o número de mensagens recebidas no mês, o que nos permite comprovar que apenas cerca de $5 \%$ das correspondências recebidas é publicada.

Entre os destaques na seção, há dois tratamentos distintos. Em geral, ela perde seu formato de depoimento para ser parte de um texto elaborado pela redação sobre o assunto. Mas, na seção "Super 20 anos", os leitores são convidados a escrever sobre sua longa relação com a revista e os depoimentos são publicados ainda na "voz" do leitor.

Superinteressante traz ainda uma das poucas experiências na imprensa brasileira em que a ficção é incorporada ao jornalismo: a coluna "E se..." constrói, com o auxílio de pesquisadores e especialistas, um cenário imaginário em função de uma afirmação ficcional.

Cobrindo a vida social e privada de celebridades, Caras não oferece nenhum espaço para os leitores, nem mesmo a seção de cartas. E, mesmo na narrativa das histórias pessoais dos famosos não há espaço para os depoimentos em primeira pessoa tudo é narrado pelo veículo. O máximo a que se chega é o formato de entrevista em pergunta e resposta. A revista é semanal.

Seleções é um típico almanaque, com curiosidades, piadas, histórias curtas, matérias jornalísticas. A periodicidade é mensal. 
A seção de cartas "Agora digo eu" traz comentários sobre as matérias das edições anteriores. Mistura um pouco de histórias pessoais às avaliações e algumas são respondidas pelo editor.

Na coluna "Saúde na medida", Solange Frazão responde a dúvidas sobre condicionamento físico dos leitores.

Os leitores podem participar de várias seções, em geral relacionadas ao humor, e são remunerados por isso. Piadas são publicadas em "Ossos do Ofício" (humor no trabalho), "Piadas de caserna" (experiências nas Forças Armadas), "Rir é o melhor remédio" (gerais) e "Flagrantes da vida real", (experiências que revelem a natureza humana e mostrem aspectos interessantes da vida brasileira). Itens e artigos retirados de jornal e revista, ou transcritos de rádio, TV ou internet, sobre pessoas e temas brasileiros podem ser publicados em "Heróis de hoje", "Só no Brasil", "Sua vida" e "Entre aspas".

Das revistas de maior circulação, Playboy é a única publicação masculina. Mensal, trata, basicamente, de temáticas relacionadas ao sexo e à conquista e traz ensaios de nu feminino. Entre os espaços oferecidos para o seu público está sua seção de cartas "Caro Playboy". São duas páginas, em que os leitores comentam os ensaios e matérias publicadas nas edições passadas assim como respondem questões formuladas pela revista ${ }^{89}$ e participam de concursos. Como é freqüente nas revistas em geral, há uma tabela com os índices de correspondências no mês anterior, indicando número total de correspondências recebidas e alguns assuntos mais abordados. A Revista costuma responder aos

\footnotetext{
${ }^{89}$ Uma questão que é feita em todas as edições é "Onde está escondido o Coelhinho na capa da Revista." O coelhinho em questão é o símbolo da Playboy.
} 
comentários dos leitores e algumas correspondências recebem destaque das demais.

Leitores participam também da Seção “Playboy responde", com dúvidas diversas que são respondidas pela própria revista ou por especialistas. Ocupa cerca de duas páginas a cada edição. Finalmente, os leitores participam de "As Piadas de Playboy" que ocupa a última página da revista. Em todas as contribuições, os leitores são identificados pelo nome, cidade e estado.

Playboy praticamente não investe na publicação de histórias pessoais de seu público, nem como depoimentos nem mesmo como personagens das reportagens.

Monet é a revista elaborada mensalmente para os assinantes da operadora de TV Net, mas que também é vendida em bancas. A maior parte de suas páginas trata dos destaques da programação dos canais distribuídos pela operadora. Há matérias ainda sobre cinema, cultura, música, variedades que, em geral, fazem ligação com algum programa que será veiculado pelos canais. Há também informações sobre a própria operadora, os recursos e pacotes oferecidos e as promoções realizadas. Praticamente metade da revista é ocupada pela programação dos principais canais dia a dia.

Para os leitores, o único espaço é a seção "A Palavra é dos Nets", que ocupa dois terços de uma página e que traz perguntas dos leitores (em geral sobre programas veiculados, artistas ou mesmo destaques das programações) respondidas pela redação da revista.

Entre as femininas, a precursora do modelo de magazine moderno, Claudia, é também a primeira em circulação. $A$ revista é mensal. A participação das leitoras começa logo no início: 
em "Claudia online" além dos destaques e programação do site, já é possível conferir a opinião de leitores sobre alguns dos temas da edição.

Depois, a seção "Sua Opinião" com uma página reúne as correspondências das leitoras em geral sobre as matérias da revista ou sobre as temáticas abordadas por elas. Os depoimentos de experiências pessoais associados aos pontos de vista apresentados são freqüentes.

A revista mantém também espaço para as leitoras tirarem suas dúvidas sobre questões jurídicas em "A Lei e você", beleza em "Consulta de Beleza", e sobre relacionamentos em "Relações delicadas". As leitoras podem ainda participar de uma transformação na seção "De visual novo".

Os depoimentos estão presentes em grande parte das matérias, mas com mais destaque nas mais longas, ainda que, na maioria das vezes, sejam mesclados ao texto da matéria.

Já em Nova, também mensal, a seção de cartas chamase "Opinião Livre" e, em cerca de três páginas, traz a repercussão das matérias das edições anteriores junto às leitoras. Alguns temas são estimulados via site. O tema mais debatido em cada edição recebe destaque e uma coluna Contra/A favor, com destaque para duas respostas enviadas pelas leitoras. Respostas masculinas (raras) também costumam ser destacadas.

Os depoimentos em primeira pessoa estão em várias seções: "Test-Drive" traz a experiência com algum novo produto, dieta, mostrando uma história pessoal e ocupando uma página inteira.

Já "Confissões de um conquistador" foi uma série de um ano em que um modelo contava suas aventuras e relações com 
mulheres e ao mesmo tempo respondia dúvidas das leitoras sobre conquista e relacionamentos.

"Depoimento" traz o relato de uma leitora em primeira pessoa e que ocupa mais de duas páginas. Trata-se de uma história longa, recheada de detalhes. O depoimento é prestado a uma jornalista que assina a matéria embora o texto inteiro esteja em primeira pessoa. Segundo a diretora de Nova, Cynthia Greiner, alguns depoimentos são enviados e outros são buscados pela equipe de Nova. ${ }^{90}$

A revista traz ainda os famosos consultórios: "Consulta íntima", onde uma ginecologista responde a dúvidas das leitoras; "Terapia de 5 minutos", com um psiquiatra e "Comer bem faz bem", para dúvidas de alimentação. Nova mantém também uma consultoria para dilemas financeiros das leitoras e uma coluna de transformação, "Banho de nova".

Manequim é uma revista feminina, de periodicidade mensal, especializada em moda e corte e costura. Seu único espaço destinado às leitoras chama-se "Manequim responde", em que a revista responde às dúvidas sobre moda e acessórios. São cerca de quatro páginas a cada edição.

Outra revista feminina, de periodicidade mensal, com temáticas especificamente voltadas para beleza (forma física) é Boa Forma. Sua seção de cartas "Interativa" traz opiniões das leitoras sobre a principal matéria da edição anterior e o resultado da enquete realizada pela revista junto às leitoras, além das demais correspondências. Os relatos das leitoras sobre suas experiências na perda e manutenção de peso, se selecionados, são publicados em destaque na seção e a leitora recebe como prêmio, uma assinatura da revista.

${ }^{90}$ Entrevista por e-mail à autora desta Tese. Disponível no Anexo 1. 
Há várias seções com respostas a perguntas que, no entanto, não têm seus autores identificados. A revista realiza também, periodicamente, concursos com as leitoras. Neste caso, as vencedoras têm suas fotos (antes e depois) e seus relatos de experiência publicados. Em geral, as narrativas são curtas e em primeira pessoa.

Marie Claire, de periodicidade mensal, tem uma seção de cartas ("Fale conosco") com apenas uma página, ilustrada com fotografias e reproduções gráficas das matérias comentadas. A que gerou mais comentários é separada em um box. Novamente, o tema principal são as próprias matérias da revista que são comentadas a partir do relato de experiências pessoais do público.

"Carta para você" é uma coluna em tom de depoimento em que Adriano Silva fala da visão e dos dilemas masculinos frente ao universo feminino.

O ponto forte é a seção "Eu, leitora", que recebe o subtítulo de "Marie Claire - vida real". O depoimento, totalmente em primeira pessoa, ocupa cerca de quatro páginas da revista a cada edição. No final da seção, junto com as instruções para leitoras enviarem seus depoimentos, há o aviso em destaque "Só publicamos histórias VERÍDICAS. Se for necessário, omitiremos seu nome". Na abertura da matéria consta o nome da jornalista responsável pelo texto publicado, na forma de "Depoimento a...". A seção aparece no índice da Revista na parte de Reportagens, denotando seu conteúdo jornalístico. Não há na revista os famosos consultórios.

Mesmo sem figurar entre os vinte veículos de maior circulação nacional a revista Sou + Eu! merece destaque. Lançada em novembro de 2006, a revista semanal é praticamente toda feita a partir de histórias e contribuições enviadas pelos leitores (no 
caso, mais leitoras). Sou + Eu!, no primeiro semestre de 2007 alcançou a 84a posição no ranking com a circulação média de $59.730^{91}$. A revista, das colunas fixas tradicionais de revistas femininas como beleza, saúde e culinária, às matérias sobre temas variados (no caso experiências de vida), é totalmente feita com colaborações dos leitores.

Todas as contribuições - até mesmo as perguntas encaminhadas para a seção "Consultório" - são remuneradas, sendo que, em setembro de 2007, o valor mínimo pago era de $\mathrm{R} \$$ 50,00 e o máximo de $\mathrm{R} \$ 500,00$ - por uma matéria de três páginas. As contribuições podem ser enviadas por e-mail ou carta.

${ }^{91}$ Dados do IVC - Instituto de Verificação de Circulação. 


\section{Mídia Eletrônica}

Desde sua origem - em 1896, com as primeiras transmissões sem fio e em 1916, com a instalação da primeira emissora de rádio em Nova York (MICROFONE, 2007) -, o mais antigo meio de comunicação eletrônico teve o estigma da interatividade. Foi graças à sua capacidade bidirecional de comunicação que BRECHT (Cf. 1981) definiu o rádio como um meio interativo. BRECHT acreditava que a comunicação em duas mãos seria concretizada com a expansão da nova mídia. E, inicialmente, com o rádio sendo realizado por sociedades estabelecidas pelo seu próprio público, essa perspectiva não era, de forma alguma, absurda.

No entanto, com o desenvolvimento do meio, essa potencialidade não foi devidamente concretizada e a interatividade permanece praticada sempre sob o controle do emissor:

“Na prática, o ouvinte, como fonte direta de (re)alimentação do sistema só participa na medida em que atende aos interesses do próprio sistema, nunca para questioná-lo. Por outro lado, como fonte indireta, as expectativas do público-alvo são levadas em consideração não apenas com o objetivo de manter a fidelidade da audiência já conquistada, mas também com o intuito de ampliá-la." (ORTRIWANO, 2000, grifos da autora)

Essa limitação na potencialidade interativa do rádio, também é apontada por MEDITSCH (1999, p. 212) ao abordar as perspectivas de evolução do meio:

"A Interatividade efetiva que a eletrônica proporciona, e que poderá ainda proporcionar melhor num futuro próximo da rádio, com o fim da excassez da banda de transmissão, circunscreve-se-á provavelmente a potencializar o ouvinte como sujeito 
da recepção do enunciado, e não exatamente de sua enunciação."

No entanto, em relação aos demais meios de comunicação de massa, o rádio é um dos mais interativos, permitindo que o público participe e se identifique com sua emissora preferida.

"No final das contas, o rádio é relacionamento. Muito mais que na televisão, o apresentador ou o DJ estabelece uma espécie de ligação com o ouvinte. Uma emissora bem-sucedida é mais do que a soma de seus programas; ela entende a natureza dessa amizade e seu papel de líder e prestador de serviços." (MCLEISH, 2001, p. 24)

Esse entendimento de sua natureza e a busca de aproximação com o público-ouvinte levou o rádio a, desde o início, buscar e estimular a participação desse público em sua programação.

No Brasil, por exemplo, o início do rádio - em 6 de abril de 1919, com a fundação da Rádio Clube de Pernambuco por Oscar Moreira Pinto, no Recife (A CRIAÇÃO, 2007) se deu com as sociedades de radiodifusão em que as programações eram feitas, muitas vezes, com discos dos próprios ouvintes e as despesas da emissora pagas pelos ouvintes-associados, já que a publicidade era proibida. É por isso que as primeiras emissoras tinham em sua denominação os termos clube ou sociedade (ORTRIWANO, 1985, p.14).

O início já demonstrava que o relacionamento com os ouvintes seria a tônica da nova mídia. No entanto, quer pelo número de emissoras e de horas de veiculação, quer pelo número reduzido de ouvintes em função do custo dos aparelhos receptores, o rádio neste início é um meio elitista. 
Essa situação só vai começar a ser alterada com a implantação do rádio comercial já nos 30. Principalmente a partir do momento em que os anunciantes percebem que, com o grande número de analfabetos no país, o meio radiofônico é uma alternativa mais eficiente para a publicidade de seus produtos. (ORTRIWANO, 1985, p.16)

O desenvolvimento do rádio é marcado pelo relacionamento com o público. Assim, em 1935, a Rádio Kosmos, de São Paulo, cria o primeiro auditório no rádio brasileiro. É a partir daí que os programas de auditório, com a presença e, muitas vezes, participação do público, irão se disseminar no país (ORTRIWANO, 1985, p.17). Esses programas de auditório têm sua origem nos programas de calouros, uma das primeiras participações sistemáticas do público no rádio brasileiro.

"Mistura de programa radiofônico, show musical, espetáculo de teatro de variedades, circo e festa de adro (o que não faltavam eram sorteios), esses programas chegaram a alcançar uma dinâmica de apresentação que conseguia manter o público dos auditórios em estado de excitação contínua durante três, quatro e até mais horas. Para isso os animadores dos programas contavam não apenas com a presença de cartazes de sucesso garantido junto ao público, mas ainda com a colaboração de grandes orquestras, conjuntos regionais, músicos solistas, conjuntos vocais, humoristas e mágicos, aos quais se juntavam números de exotismo, concursos à base de sorteios e distribuição de amostras de produtos entre o público." ( TINHORÃO, 1981, p. 70)

E a participação do público é cada vez mais significativa nesses programas:

"O programa de auditório, na verdade, era tudo: em lugar do humor político, o riso gratuito que se obtinha levando ao ridículo uma pessoa do próprio auditório; em vez de personagens de ficção (...) a realidade de gente que, de tanto freqüentar os auditórios, acabava se tornando parte deles (muitas vezes os animadores comemoravam o aniversário 
desses freqüentadores de auditório, estranhos tipos que amanheciam na Rádio Nacional e lá ficavam até de noite, ano após ano)." (SAROLDI; MOREIRA, 1984, p.

38)

É em seu auditório que a Rádio Kosmos vai criar o "Chá Dançante", onde, além do estúdio, há um salão para danças com palco para orquestra, um bar e garçons para servirem as mesas dos freqüentadores: o público da emissora. A valorização do público, dentro da emissora, é demonstrada também pela Rádio Cultura que mantinha vários funcionários fardados para indicar os caminhos (TESSER, 1994, p. 39).

Além dos shows de calouros e dos programas de auditório (assistindo ou participando de concursos variados), as cartas também foram uma forma efetiva (e ainda são) de participação dos ouvintes na rotina e na programação das emissoras. São vários os exemplos de programas que, ainda na década de 30 , se utilizavam das cartas para estabelecer diálogos com o público.

Entre os femininos, um dos pioneiros, "A Hora do Lar", da Rádio Guanabara, do Rio de Janeiro, recebia, em média, 250 cartas por mês. Já em "A Hora Feminina", da Rádio Cruzeiro do Sul, também do Rio de Janeiro, a locutora Ilka Labarthe recebia diariamente cartas de uma ouvinte deficiente física com quem estabeleceu um extenso diálogo:

"'Senhora, afastei todos de junto de mim, até mesmo a enfermeira que continuamente tenho ao meu lado, queria ouvir a sua resposta sozinha, como sempre estou, com minha dor. Fiz-me transportar para a sala de música, liguei o Rádio e recolhidamente escutei as palavras boas e humanitárias que me dirigiu. Seria hipocrisia confessar que meu amargor e meu sofrimento desapareceram. Mas a dor de outras criaturas que citou no programa são bem maiores que as minhas.' Para Ilka, a estória dessa moça foi um caso doloroso, ela tinha 22 anos quando sofreu um 
desastre e ficou paralítica. Durante muito tempo trocou correspondência com a locutora e depois se tornaram amigas." (TESSER, 1994, p. 39)

Já na década de 40, nos Anos de Ouro do rádio, "a Rádio Nacional recebia uma média mensal de 26.291 cartas de várias regiões do país" (SAROLDI; MOREIRA, 1984, p. 27). Em 1956, a emissora atingia a fabulosa marca de 110 mil cartas/mês, sendo que $84,1 \%$ delas eram destinadas aos programas com concursos (SAROLDI; MOREIRA, 1984, p. 79).

Os concursos muitas vezes serviam para medir a audiência dos programas. A primeira radionovela do rádio brasileiro "Em busca da felicidade", de 1941, tinha o patrocínio do creme dental Colgate. Para medir a sua audiência, já que a radionovela ia ao ar de manhã (um horário de baixa audiência naquela época), a agência Standart Propaganda, responsável pela conta do produto, criou uma promoção em que os ouvintes deveriam enviar um rótulo de Colgate para receber um brinde que consistia em um álbum com fotos dos artistas e o resumo dos capítulos que já tinham sido apresentados. Somente no primeiro mês, foram $48 \mathrm{mil}$ cartas recebidas o que levou à suspensão da promoção. (CALABRE, 2003, p. 4-5)

As cartas, lidas e muitas vezes respondidas no ar não são exclusividade do rádio das décadas de 30 e 40 e muito menos do Brasil. "Palavras na brisa noturna" se tornou mundialmente conhecido depois que sua criadora e apresentadora, a jornalista chinesa XINRAN publicou o livro "As boas mulheres da China" em que relata sua experiência:

"Em Palavras na brisa noturna, eu tentava abrir uma janelinha, um buraco minúsculo, para que as pessoas pudessem desabafar e respirar, depois da atmosfera carregada de pólvora dos quarenta anos precedentes." (XINRAN, 2003, p. 15, grifos da autora) 
No período de abertura política da China, iniciado por Deng Xiao Ping, o programa se tornou um marco por trazer à tona a realidade das mulheres chinesas e por gerar um espaço de discussão dessa realidade através das narrativas de experiências pessoais das ouvintes:

"As cartas que recebia dos meus ouvintes, cheias de anseios e esperança, foram o meu ponto de partida. Perguntei ao meu diretor se podia acrescentar, no final do programa, um espaço especial para mulheres, onde eu iria discutir e talvez ler em voz alta as cartas recebidas. (...) O impacto dos meus dez minutos para cartas de mulheres foi muito além das minhas expectativas: o número de cartas aumentou, a ponto de eu me ver recebendo mais de cem por dia. Seis estudantes universitários tiveram que vir me ajudar no trabalho. Os assuntos das cartas também se diversificaram mais. As histórias que as ouvintes me contavam tinham ocorrido no país inteiro, em vários momentos dos últimos setenta anos, mais ou menos, e vinham de mulheres com antecedentes sociais, culturais e profissionais bem diferentes. Revelavam mundos ocultos das vistas da maioria da população, inclusive de mim mesma. Eu me emocionava profundamente com as cartas. Muitas incluíam toques pessoais, como flores, folhas ou casca de árvore prensadas, e lembrancinhas de crochê." (XINRAN, 2003, p. 21-2)

É claro que nem só de cartas vive a participação do público nos programas de rádio: o telefone é também um importante aliado desta mídia. Através dele, década após década, os ouvintes vêm conversando com locutores e produtores das emissoras e também participando da programação.

Nos anos 60, na Rádio Bandeirantes, de São Paulo, a apresentadora Xênia Bier recebia ligações de suas ouvintes que narravam seus problemas e recebiam conselhos e opiniões. Além da própria apresentadora, discutiam os problemas levados ao ar, psicólogos e educadores convidados (MAIA, 2002, p. 101). 
O telefone é a base também de vários programas musicais em que a participação dos ouvintes é relacionada aos pedidos e oferecimentos musicais. "Telefone pedindo Bis", na Rádio Bandeirantes dos anos 50 é um dos mais conhecidos. Na mesma emissora, o apresentador Miguel Vaccaro Neto, do programa "Não Diga Não", ligava para um número aleatório de telefone e conversava com quem atendesse. Se a pessoa conseguisse ficar sem falar a palavra "não", ganhava prêmios. (ADAMI; BARBOSA FILHO, 2007, p. 25)

Também em suas décadas iniciais ( 30 e 40), os ouvintes podiam participar dos programas de perguntas e respostas (quiz shows) que se multiplicavam no rádio. O precursor foi "Pergunte o que Quiser", lançado pela Rádio Kosmos em 1937. (ADAMI; BARBOSA FILHO, 2007, p. 20)

É essa participação que levará o rádio, ao fim da sua Era de Ouro, a encontrar seu novo espaço no sistema midiático, reforçando seus vínculos com o local e com as comunidades à sua volta e segmentando sua programação a fim de atender especificamente a um determinado público:

"Ao criar e estimular formas de participação, dando voz aos ouvintes, o rádio passou a ser também um canal através do qual se colocam reclamações, reivindicações e opiniões perante diversos atores sociais que vão de empresas privadas até órgãos de administração pública. Nesta situação, o comunicador exerce papel de intermediador entre as questões colocadas pelos ouvintes e respostas que recebem dos atores envolvidos." (ESCH, 2001, p. 83)

Esta participação do público em busca de atendimento às suas demandas junto às autoridades e órgãos, embora não seja novidade, irá se acentuar à medida que o rádio vai perdendo seus espaços para shows e o glamour correspondente. As emissoras jornalísticas e as populares irão se especializar neste atendimento, 
com quadros e programas voltados ao atendimento das demandas da população.

Mas se as formas de participação (carta, telefone, email) são as mesmas para as emissoras em geral, o tipo de programação irá definir qual o conteúdo, dentre os muitos apresentados pelo público, que será selecionado e até incentivado pela rádio.

Nas emissoras jornalísticas, o espaço criado para a participação está em enquetes sobre determinado assunto, perguntas em entrevistas/debates e, mais recentemente, a incorporação (e veiculação na programação) de opiniões dos ouvintes (em geral, enviadas por e-mail) sobre determinado tema. Mais recentemente, inclui também as informações do público (em geral sobre o trânsito) exercendo o papel de repórteres, ou ouvintes-reporteres.

Ouvinte-repórter é um termo cunhado pela Rádio Eldorado, de São Paulo, para definir os ouvintes que passaram a participar da programação da emissora na hora do rush dando informações sobre o trânsito nas regiões em que se encontravam ou que acabavam de passar, via celular. Atualmente, a experiência aparece em diversas emissoras e os ouvintes são convidados não só a informar sobre os caminhos na metrópole (informação muito importante numa cidade como São Paulo, em que os congestionamentos são diários), mas também sobre outros fatos da cidade.

No entanto, para as histórias pessoais do cidadão anônimo, os espaços são reduzidos e, a exemplo do que se encontra nos jornais, elas estão presentes mais fortemente em reportagens especiais e rádio-documentários, em que a escolha (e construção) de personagens é uma técnica mais desenvolvida. 
Nas emissoras musicais, o espaço destinado ao público está muito relacionado à escolha de músicas, participação ao vivo por telefone (em jogos, programas ou promoções) e até na "produção de programas". No dial paulistano, uma das experiências de grande sucesso foi o "Toque Outra Vez", levado ao ar pela Rádio USP entre 1990 e 1995 e que apresentava ao ar uma seleção musical com uma hora de duração feita por um ouvinte da emissora diariamente. O programa chegou a ter uma espera de até um ano para que o ouvinte tivesse sua seleção atendida.

Finalmente, nas emissoras populares, o espaço incorpora também a participação de ouvintes mandando recados para seus conhecidos/familiares e a leitura e interpretação de cartas de ouvintes narrando suas vivências/histórias pessoais, que são divulgadas pela emissora de rádio para os demais ouvintes.

É claro que esse tipo de programa não é exclusividade das emissoras populares. Várias rádios voltadas a classes sociais mais altas também utilizam esse recurso. Um exemplo, que esteve no ar até junho de 2006, foi "A Hora das Perdidas" que a 89 FM levava ao ar e que mantinha quadros em que ouvintes ligavam para contar seus problemas/dilemas pessoais e ouvir conselhos dos apresentadores. No entanto, esse tipo de quadro é mais característico e vem sendo trabalhado há mais tempo pelas rádios populares.

São essas narrativas que nos interessam por se tratarem de histórias/vivências de pessoas desconhecidas que são enviadas para a mídia pelo próprio autor e que, para serem veiculadas, recebem o tratamento característico do meio radiofônico.

É importante notar que, tal qual no impresso, o relato original sofre a atuação de profissionais a fim de adequá-la à 
linguagem do programa/emissora. Além da re-elaboração do texto, estamos falando aqui também da incorporação à palavra dos demais elementos de linguagem radiofônica: a música, os efeitos sonoros e o silêncio. ${ }^{92}$

Combinados entre si ou atuando isoladamente, eles contribuem para a apreensão do todo da mensagem radiofônica. No entanto, é importante salientar que a linguagem radiofônica não é produto direto da simples somatória desses elementos, mas sim o resultado de sua codificação a partir dos recursos de elaboração, reprodução e de percepção da mensagem radiofônica.

Um dos grandes exemplos da utilização dos vários elementos da linguagem radiofônica na história do rádio é a veiculação da "Guerra dos Mundos", de 1938, pela rádio CBS americana. Uma adaptação da obra do escritor inglês H. G. Wells, com direção de Orson Welles:

"No especial do Raditeatro Mercury da véspera do Dia das Bruxas de 1938 - denominado Mercury's Halloween Show -, usando somente sons e silêncios, foi representada uma invasão de marcianos sob a forma de uma cobertura jornalística. Todas as características do radiojornalismo usadas na época às quais os ouvintes estavam habituados e nas quais acreditavam - se faziam presentes: reportagens externas, entrevistas com testemunhas que estariam vivenciando o acontecimento, opiniões de especialistas e autoridades, efeitos sonoros, sons ambientes, gritos, a emotividade dos envolvidos, inclusive dos pretensos repórteres e comentaristas, davam a impressão de um fato, que estava indo ao ar em edição extraordinária, interrompendo outro programa, o radioteatro previsto." (ORTRIWANO, 2007)

\footnotetext{
${ }^{92}$ Segundo BALSEBRE (1994, p. 18), “... o conjunto de formas sonoras e não sonoras, representadas pelos sistemas expressivos da palavra, da música, dos efeitos sonoros e do silêncio, cuja significação vem determinada pelo conjunto de recursos técnico-expressivos da reprodução sonora e pelo conjunto de fatores que caracterizam o processo de percepção sonora e imaginativo-visual dos radiouvintes".
} 
Se o grande marco do rádio mundial utilizou-se de elementos do jornalismo numa peça de ficção, o contrário também é muito explorado: nos programas radiofônicos, multiplicam-se os exemplos em que dramatizações são utilizadas para a narrativa de notícias.

\section{Televisão}

Em março de 1945, ocorre a primeira transmissão de televisão na Alemanha e, em novembro, na França. Em 1936 é a vez de Londres com a inauguração da BBC e em 1939, a televisão chega aos Estados Unidos, onde a NBC - National Broadcasting Company transmitia para 400 aparelhos em Nova York. (A HISTÓRIA DA TELEVISÃO, 2007)

Em 1939 é feita a primeira transmissão de TV em circuito fechado no Brasil. Mas a TV brasileira irá realmente surgir apenas em 1950, em São Paulo, numa iniciativa de Assis Chateaubriand. A primeira emissora foi a Tupi de São Paulo, inaugurada no dia 18 de setembro.

Inicialmente, a nova mídia apropriou-se e tentou reproduzir a experiência do rádio, inclusive copiando modelos de programações. Era um rádio com imagem. E, nesta importação de modelos, a televisão repetiu, logo em seu início, a vinculação da participação do público aos auditórios, concursos e enquetes.

Em 1955 foi ao ar o primeiro programa de perguntas e respostas com premiação da TV brasileira: "O Céu é o Limite", da TV Tupi, apresentado por Aurélio Campos, em São Paulo e J. Silvestre no Rio de Janeiro, em que os participantes concorriam a prêmios tal qual nos quiz shows do rádio.

Este tipo de participação, com premiação, será a marca registrada de outro apresentador, Sílvio Santos, hoje dono da rede 
SBT. Sua estréia acontece em 1961, na então TV Paulista, com o programa "Vamos brincar de forca" (A HISTÓRIA DA TELEVISÃO NO BRASIL, 2007).

A complexidade técnica da TV dificultou um pouco a criação de espaços para as contribuições do público, limitando o tipo de participação e, algumas vezes, restringindo-os ao papel de platéia em programas de auditório. No entanto, o fascínio que o sonho de participação nessa mídia desperta é um dos mais significativos em todo o sistema de mídias. Nenhum outro meio encarnou tão bem $\mathrm{o}$ papel de espelho onde $\mathrm{o}$ indivíduo vê confirmada sua existência e identidade.

É na televisão também que encontramos mais facilmente um maior número de registros quanto aos programas veiculados pelas emissoras, em parte porque o número de emissoras sempre foi significativamente menor que o de veículos das mídias anteriormente abordadas e em parte porque, ao ocupar o centro do universo midiático já nos anos $60^{93}$ e se manter nesta posição até o momento, a televisão tem atraído para si os olhares de pesquisadores. No entanto, é necessário ressaltar que as recentes publicações de auto-documentação da Rede Globo de Televisão, na comemoração de seus 40 anos, em 2005, ainda não encontram paralelo nas demais emissoras, forçando a que o registro de suas experiências tenha mais destaque que as demais neste trabalho.

Pelo Almanaque da TV Globo (MAIOR, 2006, p. 21), por exemplo, podemos notar que logo em seu primeiro ano de funcionamento (1965), a emissora criou um programa infantil (UniDuni-Tê) que apresentava cartas e desenhos enviados pelos

\footnotetext{
93 Já em 1966, a Televisão recebia 39,5\% das verbas publicitárias contra 23,3\% para as Revistas, $17,5 \%$ para o Rádio, $15,7 \%$ para os J ornais e $4 \%$ para outros. (A HISTÓRIA DA TELEVISÃO NO BRASIL, 2007)
} 
telespectadores mirins à emissora (exatamente como os suplementos infantis dos jornais). O programa ficou no ar seis anos.

Ainda em 1965, a TV Globo veicularia um programa em que o público anônimo aparecia com destaque mas no papel de vítima: as pegadinhas - tão famosas novamente nos anos 90 daquela época eram veiculadas no programa Câmera Indiscreta. Tratava-se de uma versão do enlatado Candid Camera (exibido pela $A B C$ desde 1948). Quem pregava as peças eram Renato Consorte, Gracinda Freire e Don Rossé Cavaca. O slogan era: “Sorria, você está no Câmera Indiscreta!". (MAIOR, 2006, p. 23)

Mas o grande evento envolvendo a participação do público nestes primeiros anos de TV Globo acontece em 1967 durante o programa "Casamento na TV", em que moças e rapazes apareciam em busca de um namorado. O programa ficou abaixo das expectativas de audiência:

"até o dia em que irrompeu no palco - com a devida autorização da produção - uma jovem grávida e furiosa.

Ela avançou na direção de um candidato a noivo e, como dedo em riste, acusou o 'oferecido' e 'semvergonha' de ser o pai de seu filho. No dia seguinte, o caso estava em todos os jornais: 'Escândalo na TV'.

Graças à grávida, o Casamento na TV virou notícia e caiu nas graças do público." (MAIOR, 2006, p. 46 , grifos do autor)

Já era a vida real chamando atenção e conquistando audiência.

Sobre isso, BOURDIEU (1997, p. 16-7) destaca que a TV impede mesmo a possibilidade de expressão e argumentação e que o único motivo para que uma pessoa aceite ir a uma emissora televisiva, sabendo que não poderá falar e tampouco será ouvido, é o "se fazer ver e ser visto", numa espécie de espelho narcísico. 
À parte do fascínio despertado pela televisão ou justamente em função dele ${ }^{94}$, com o desenvolvimento do meio e sua evolução técnica, os espaços para o público participar de sua programação começaram a ser diversificados.

É importante ressaltar que a mesma complexidade técnica que limitou a programação ao vivo e o desenvolvimento do imediatismo da TV, permitiu que ela suplantasse o rádio na realização de programas de ficção, assumindo como seu este gênero de programação e condenando a experiências isoladas os trabalhos de radiodramaturgia (radionovelas, por exemplo). E é justamente esse recurso (o da dramaturgia) que vai permitir ao meio televisivo buscar desenvolver de maneira diferenciada os espaços para a veiculação das histórias pessoais de seu público.

Mesmo nos programas jornalísticos, os recursos de dramatização vêm sendo usados para encenar histórias da vida real. Aliás, segundo BOURDIEU (1997, p. 25), "a televisão convida à dramatização, no duplo sentido: põe em cena, em imagens, um acontecimento e exagera-lhe a importância, a gravidade, e o caráter dramático, trágico."

Um dos precursores no Brasil é o programa "Perspectiva", colocado no ar pela TV Cultura já em 1969. O programa utilizava elementos de ficção para enfatizar situações reais do cotidiano. O primeiro programa, por exemplo, foi uma reportagem sobre a construção do metrô de São Paulo e trazia algumas cenas teatralizadas para mostrar a necessidade da instalação do novo transporte. (A HISTÓRIA DA TELEVISÃO NO BRASIL, 2007)

\footnotetext{
${ }^{94} \mathrm{Na}$ construção do Sistema de Mídias, a televisão ocupou um papel central em relação às demais e em sua relação com a sociedade.
} 
Em abril de 1982, a já Rede Globo de Televisão lança o "Caso verdade", com dramatizações das histórias enviadas pelo público. Teve 152 programas exibidos e ficou quatro anos no ar:

"Exibidos em cinco capítulos, com 25 minutos de duração cada, a partir das $17 \mathrm{~h} 30$, os casos eram selecionados por Walther Negrão e Ely Santos, que tratavam de transformar a vida real em dramaturgia. (..) Em alguns episódios, a dramaturgia era pontuada pelos depoimentos dos personagens reais e entrevistas com especialistas no tema abordado. capítulo.

O fim da história era exibido sempre no penúltimo

No último capítulo, personagens da vida real e da ficção se encontravam para debater o drama em desfechos jornalísticos.

$\mathrm{Na}$ pauta e no roteiro, temas polêmicos como alcoolismo, estupro, suicídio, incesto e erros judiciários." (MAIOR, 2006, p. 212)

O programa saiu do ar em 1986, dando lugar ao "TeleTema", de ficção.

É claro que esses espaços não são exclusivos dos programas com recursos de dramatização e tampouco são invenções recentes. No jornalismo televisivo, a utilização de personagens construídos através das histórias de anônimos nas reportagens (e, principalmente, nos programas temáticos ou teledocumentários) é um fato comum.

Em 1973, a Rede Globo inova com a estréia do "Globo Repórter":

"A ordem era ousar. A câmera seria os olhos do telespectador e nenhum repórter seria escalado para traduzir a realidade. Os depoimentos dos entrevistados nos guiariam a cada programa." (MAIOR, 2006, p. 110)

Entre os destaques desse modelo de "Globo Repórter" estava a história do Coronel Teodorico Bezerra, dono de uma fazenda no interior de Pernambuco: 
"Foi o próprio Teodorico quem contou sua saga e nos guiou por sua cidade particular, onde os colonos moravam "de graça" em troca de voto, trabalho e obediência cega ao coronel. Ali era proibido beber, dançar, fumar, jogar... e todos tinham a obrigação de votar no dono das terras.

Os vetos estavam todos pintados nas fachadas das casas simples dos moradores, e as instruções do coronel eram anunciadas à comunidade por meio de alto-falantes espalhados pelos postes dessa Sucupira real e inacreditável ao mesmo tempo.

Eduardo Coutinho deu voz ao personagem, narrador único da própria história e dos próprios absurdos. Ninguém censurou o coronel." (MAIOR, 2006 , p. 110 , grifos do autor)

O programa anterior ao "Fantástico", "Só o Amor

Constrói" também investia nas histórias pessoais, de anônimos e famosos, que eram contadas a partir dos depoimentos de parentes e amigos. (MAIOR, 2006, p. 111)

A questão dos personagens anônimos que têm suas histórias narradas pela televisão perpassa uma série de programas jornalísticos. Entre eles, “Domingo Gente” foi um dos destaques da programação da Rede Globo de Televisão em 1976.

"Nada de celebridades em cena. No Domingo Gente, os holofotes apontavam para os anônimos. Para ser atração do programa bastava ter uma boa e inusitada história de vida para contar. E eles tinham." (MAIOR, 2006, p. 159, grifos do autor)

Entre as histórias apresentadas:

"Pedro Antônio - Seu hobby era realizar viagens clandestinas mundo afora. A última aventura foi uma viagem de avião à Espanha - de graça, devidamente escondido.

Yukio Takahashi - Acredite: ele preparava pratos japoneses sem tocar nos alimentos. Era o único brasileiro autorizado pelo Imperador do Japão a realizar o milenar cerimonial das facas.

Jurandir Soares de Oliveira - Cascavéis e corais que se cuidassem. Funcionário do Instituto Butantã, em São Paulo, Jurandir ganhava a vida tirando veneno de cobras pelo Brasil." (MAIOR, 2006, p. 159, grifos do autor) 
Ainda na programação da Globo, em dezembro de 1994 foi ao ar pela primeira vez o programa "Brasil Legal", apresentado por Regina Casé. O programa tratava de temas do cotidiano mostrando pessoas e lugares que, habitualmente, não encontram espaço na mídia. Seu programa de estréia, com o tema "festa" misturou famosos e anônimos ao mostrar os melhores embalos em cinco capitais: São Paulo, São Luís, Manaus e Belém. Misturando ficção e realidade, o programa incorporou o riso às narrativas. Ficou no ar até 1998 quando sua última edição falou do "descobrimento do Brasil". (DUMARESQ, 2006, p. 1-2)

O riso, apresentado por BAKHTIN (Cf. 1999) como um dos elementos de constituição da cultura popular e da construção da expressão do homem comum, em "Brasil Legal" traz com ele a denúncia da realidade:

"Utilizando a ingenuidade, a paródia, a máscara, estabelecendo-se entre o palco e a vida, Regina Casé encarna o 'bobo', o 'bufão' ou o 'trapaceiro' e consegue mostrar a vida privada do brasileiro, arrancar confissões e fazer rir. Sempre pelo choque com esta personagem que vem de fora - estranha, inquire, expõe -, o programa alcança seus momentos mais ricos. Mas as tais denúncias que Brasil Legal faz não estão diretamente ligadas ao mundo da política ou ao Estado. O programa expõe modos de vida que, mesmo quando sofrem o descaso, buscam uma alternativa de encantamento." (DUMARESQ, 2006, p. 7, grifos da autora)

Também os programas policiais utilizam narrativas das histórias das vítimas e/ou acusados para abordar o tema segurança. Entre esses programas mais populares, destaca-se também a discussão de temas do cotidiano (mais destacadamente comportamento e sexualidade) através dos depoimentos e histórias do próprio público.

"O Homem do Sapato Branco" apresentado por Jacinto Figueira Jr é um dos pioneiros na TV brasileira. Estreou em 1968 
na TV Globo e TV Paulista e reunia pessoas comuns para resolverem suas diferenças pessoais o que, geralmente, acabava em pancadaria.

Na linha de exploração dos fatos e histórias trágicas do cotidiano, um dos precursores foi "Domingo de verdade", comandado por J. Silvestre em 1968 na TV Tupi. O programa apresentava dramas tendo um júri para escolher o de maior desgraça, que recebia um prêmio.

Outro marco deste tipo de programa é o "Aqui Agora" que o SBT levou ao ar entre maio de 1991 e fins de 1997. Logo em 1998, o SBT coloca no ar o "Programa do Ratinho" que repete a fórmula de trazer anônimos para o palco para resolverem suas questões pessoais. (A HISTÓRIA DA TELEVISÃO NO BRASIL, 2007)

A vida privada/íntima do público é tema também dos programas estilo consultório sentimental. Esses programas dedicam-se a discutir principalmente temas de comportamento, relacionamento e sexualidade e utilizam-se basicamente de dois modelos: o de discussão de um caso específico, com a participação do público por telefone ou correspondência e o de discussão de vários casos sobre um mesmo tema, em geral com a presença de vários anônimos. Comum aos dois modelos está a presença quase obrigatória de especialistas para comentarem os casos.

Na linha do consultório, em 1966, o programa Dercy Espetacular passou a ocupar os domingos da TV Globo, das 19 às 22 h. Um dos principais quadros, Consultório Sentimental, trazia "telespectadores em busca de parentes desaparecidos, bolsas de estudos, cadeiras de rodas e casas para morar" (MAIOR, 2006, p. 30). As questões pessoais (ainda que na fórmula da assistência social) estavam invadindo a TV. 
A exploração da intimidade é tema também da TV Record, mas que opta por abordar os famosos. Em 1968, o programa "Quem Tem Medo da Verdade", sob o comando de Carlos Manga, trazia artistas conhecidos para serem julgados por questões e problemas pessoais. Os artistas eram remunerados para participar do programa. (A HISTÓRIA DA TELEVISÃO NO BRASIL, 2007)

Na Globo, já em 1980, o “TV Mulher" estreou trazendo para as manhãs temas de sexualidade. No quadro "Comportamento Sexual", a psicóloga Marta Suplicy respondia cartas das telespectadoras com dúvidas sobre sexualidade. (MAIOR, 2006, p. 192)

A sexualidade também é o tema central do "Erótica", da MTV, que estreou em 1999 e saiu do ar para dar lugar ao "Ponto P". Seu formato inicial era o de uma apresentadora, um especialista e um convidado conversando com os telespectadores e comentando seus problemas e dúvidas.

"Diríamos, assim, que o propósito educativo de um programa como o 'Erótica' centra-se justamente na exposição dos sujeitos, basicamente na exposição de todos os medos e inseguranças, de todas as dúvidas, pecados e transgressões - que, ao serem publicizados, são tratados no sentido de uma normalização - no sentido foucaultiano deste termo." (FISHER, 2002, p. 46, grifos da autora)

Outro modelo é o de uma espécie de mesa-redonda da vida privada, que reúne vários participantes que em geral são pessoas comuns, saídas do próprio público e, eventualmente, alguns participantes famosos. Eles são levados a discutir suas histórias, vivências e comportamentos com especialistas e com a platéia (tanto a presente no auditório quanto a que acompanha o debate pela telinha). 
Uma das pioneiras é Silvia Popovic que estreou em 1990 na Rede Bandeirantes o programa com seu nome mesclando entrevistas variadas e temas polêmicos com a participação do público. (A HISTÓRIA DA TELEVISÃO NO BRASIL, 2007)

Mas a vida pessoal do público não é mostrada apenas nos programas jornalísticos; a própria ficção tem trazido para dentro de seus espaços os dramas reais do cotidiano de anônimos. Se nos programas de jornalismo, cada vez mais, são usados recursos de dramaturgia (como nas reconstituições de histórias através de encenações, favorecendo a criação de espaços dentro da TV para as histórias pessoais do público), nesta também se busca, cada vez mais, incorporar elementos da realidade.

Em "Véu de Noiva", novela de Janete Clair levada ao ar pela Globo em 1969, o diretor Daniel Filho teve a idéia de colocar um juiz de verdade, ao vivo, no último capítulo da novela para decidir o destino de uma criança disputada pela mãe biológica e pela mãe adotiva: questão.

"Com quem deveria ficar o menino? Eis a

Nem Janete nem Daniel sabiam como o capítulo terminaria. O juiz era soberano para julgar: ao vivo, sem cortes.

Com a audiência nas alturas, o juiz bateu o martelo: a mãe adotiva - a doce, meiga e generosa Andréa - ficaria com a criança." (MAIOR, 2006, p. 66)

Já "Explode Coração", de 1995, também da Globo, incluiu imagens de crianças desaparecidas em seus capítulos com depoimentos falando dos filhos. Mais de 60 crianças foram localizadas até o fim da novela. (MAIOR, 2006, p. 360)

Em 2003, é a vez de "Mulheres Apaixonadas", de Manuel Carlos. Na abertura da novela, fotos de mulheres anônimas:

"Na abertura de Mulheres Apaixonadas, os efeitos especiais deram lugar a fotos de anônimos, todas 
mostrando mulheres com seus filhos, maridos, parentes ou amigas. A idéia era renovar as fotos todo mês. Mas a quantidade de retratos enviados à emissora pelo público foi tão grande - mais de $100 \mathrm{mil}$ -, que a vinheta passou a ser atualizada a cada 15 dias. Na última semana da novela, a abertura exibiu fotos de parentes da equipe envolvida na produção do folhetim." (MAIOR, 2006, p. 463, grifos do autor)

Também de Manoel Carlos, "Páginas da Vida", de 2006, foi a novela que mais avançou neste sentido de incorporar o público aos capítulos da ficção: diariamente, ao fim de cada capítulo, a novela exibia um vídeo em que pessoas reais contavam suas experiências de vida relacionadas aos temas que eram explorados na novela: alcoolismo, sexualidade, crianças com Síndrome de Down etc.

Entre os depoimentos, o da babá Nelly dos Santos, de 68 anos, que falava sobre seu primeiro orgasmo após ter descoberto a masturbação aos 45, gerou polêmica e circulou pela internet após ser disponibilizado no Youtube ${ }^{95}$. Por conta do tabu e da perda do emprego como babá, o episódio ganhou as páginas dos jornais e os programas sobre televisão.

Fora das novelas, não há muito espaço para a participação do público na programação de dramaturgia das televisões. Em geral, eles se resumem à participação em enquetes, sendo que o exemplo mais conhecido é o do "Você Decide", de 1992, da Rede Globo, em que o público, através de votação, decidia o final (entre dois possíveis) do episódio.

Há ainda, neste grupo de possibilidades de inserção de histórias pessoais na TV, os recém-criados reality shows ${ }^{96}$,

\footnotetext{
95 http://br. youtube. com/watch?v=ljVhtHzT6I 8 . Acesso em 05/09/07.

${ }^{96}$ Segundo a Wikipédia (REALITY SHOW, 2007), Reality show é um tipo de programa televisivo apoiado na vida real. Exemplo deste é o programa mundialmente conhecido, Big Brother criado em 1999 por John de Mol e inspirado no livro de George Orwell, "1984".
} 
reunindo pessoas em situações de confinamento a fim de retratar seus comportamentos e ações diante de situações criadas artificialmente, mas que reproduziriam situações da vida real.

No Brasil, o primeiro foi "No Limite", levado ao ar pela Rede Globo, em 2000. O programa seguia o modelo de "Survivor" americano e teve três edições brasileiras.

Na seqüência, o SBT veiculou "Casa dos Artistas", em 2001. A fórmula era a mesma do "Big Brother" mas os confinados eram artistas e não anônimos.

Mas o maior fenômeno do gênero, o "Big Brother Brasil", estreou na Globo em 2002. Os primeiros apresentadores foram Pedro Bial e Marisa Orth, mas ela saiu ainda no primeiro reality e ele permaneceu como único apresentador. Logo no ano de estréia foram duas edições, mas a partir de 2003 a emissora passou a veicular uma única edição anual. Internacionalmente, 50 países já exibiram o programa, sendo que 38 também produziram versões locais. (MAIOR, 2006, 449-51)

Entre as emissoras, o canal por assinatura People \& Arts é o que reúne a maior variedade de experiências com esse tipo de programa: são exibidos reality shows de moda ("Project Runway" e "Casa Boateng"), tatuagens ("Miami Ink"), reformas de casas ("Extreme Makeover"), empregos ("O Aprendiz"), boxe ("O Desafiante"), emagrecimento ("Perder para Ganhar"), motos ("American Chopper") ou cinema ("On the Lot").

No entanto, vários críticos diferenciam esse comportamento ao da vida particular em função de os participantes saberem que estão diante de câmeras, como se atuassem para o público: 
coisa que seja 'real' e a de que qualquer coisa que se preste ao show e ao consumo de massa pode ser chamada de intimidade." (BUCCl, 2002, grifos do autor)

Ou para PENA (2002, grifos do autor):

"Apesar da aura de realidade, os personagens dos reality shows têm que interpretar papéis pré-definidos pela produção. Ou seja, eles não são eles próprios, apenas interpretam a si mesmos, o que é bem diferente. O mocinho, a carente, o malvado, o ignorante, a sensual, o arrogante, a mal-educada, o inteligente, a doente e outras tantas caracterizações carregam o enredo da trama, sustentando conflitos e gerando identificações por parte do público. Identificações essas que podem seguir roteiros mimetizados da ficção: a vida imitando a arte."

Assim, esse tipo de programa se afasta bastante da narrativa de histórias pessoais vividas pelo público e veiculadas pela mídia já que são vividas pelo público, mas dentro da própria mídia.

\section{a. Mídia Eletrônica e Histórias Pessoais em 2007}

O IBOPE, principal órgão de pesquisa de audiência de emissoras de rádio, acompanha na Grande São Paulo 39 emissoras de rádio $F M$ e 27 emissoras AM. Em ordem de classificação, segundo os índices de audiência medidos pelo Instituto no trimestre maio/junho/julho, de segunda a sexta, das 6 às 19 horas, são:

AMs: 


\begin{tabular}{|l|}
\hline 03 - BANDEI RANTES AM \\
\hline 04 - JOVEM PAN AM \\
\hline 05 - TUPI AM \\
\hline 06 - CBN AM \\
\hline 07 - AMERICA AM \\
\hline 08 - TERRA AM \\
\hline 09 - RECORD AM \\
\hline 10 - 9 DE JULHO CATOLICA AM \\
\hline 11 - NACIONAL GOSPEL AM \\
\hline 12 - IMACULADA CONCEICAO AM \\
\hline 13 - BOA NOVA AM \\
\hline 14 - ELDORADO AM \\
\hline 15 - GAZETA AM \\
\hline 16 - MORADA DO SOL AM \\
\hline 17 - SAO PAULO AM \\
\hline 18 - METROPOLITANA AM \\
\hline 19 - MUNDIAL AM \\
\hline 20 - CULTURA AM \\
\hline 21 - UNIVERSO AM \\
\hline 22 - TRIANON AM \\
\hline 23 - NOVA DIFUSORA AM \\
\hline 24 - DACIDADE DE SP AM \\
\hline 25 - ABC AM \\
\hline 26 - MOGI NEWS - AM \\
\hline 27 - ATUAL AM \\
\hline
\end{tabular}

FMs:

\begin{tabular}{|l|}
\hline $\begin{array}{c}\text { GRANDE SAO PAULO (GSP) } \\
\text { MAIO / JUNHO / JULHO } 2007 \\
\text { GSP - SEXO AMBOS }\end{array}$ \\
EMI SSORA \\
\hline \\
\hline 01 - NATIVA \\
\hline 02 - TUPI \\
\hline $03-$ TRANSCONTI NENTAL \\
\hline $04-$ MIX \\
\hline $05-$ BAND \\
\hline $06-$ METROPOLITANA \\
\hline $07-$ GAZETA \\
\hline $08-$ JOVEM PAN 2 \\
\hline $09-89$ \\
\hline $10-105$ \\
\hline $11-$ ALPHA \\
\hline $12-$ NOVA BRASIL \\
\hline $13-$ ANTENA 1 \\
\hline $14-$ CBN \\
\hline $15-$ KISS \\
\hline $16-$ REDE ALELUIA \\
\hline
\end{tabular}




\begin{tabular}{|l|}
\hline $17-$ IMPRENSA \\
\hline $18-$ TRANSAMÉRICA \\
\hline $19-$ TROPICAL \\
\hline $20-$ TERRA \\
\hline $21-$ MUSICAL \\
\hline $22-$ NOSSA RÁDIO \\
\hline $23-$ ENERGIA 97 \\
\hline $24-$ BANDEI RANTES \\
\hline $25-$ BANDNEWS \\
\hline $26-$ VIDA \\
\hline $27-$ CULTURA \\
\hline $28-$ ELDORADO \\
\hline $29-$ SCALLA \\
\hline $30-107$ \\
\hline $31-$ ÔMEGA \\
\hline $32-$ ATUAL \\
\hline $33-$ SULAMÉRICA TRÂNSITO \\
\hline $34-$ USP \\
\hline $35-$ MUNDIAL \\
\hline $36-$ MAIS \\
\hline $37-$ APOLLO \\
\hline $38-$ FELIZ \\
\hline $39-92$ \\
\hline
\end{tabular}

Conforme definido na metodologia, acompanhamos a programação das cinco primeiras colocadas de cada um dos grupos $^{97}$.

Entre as AMs, das cinco primeiras colocadas no ranking de audiência, três são populares (Globo - 1100 kHz, Capital - 1040 kHz e Tupi - 1150 kHz) e duas são jornalísticas (Bandeirantes $840 \mathrm{kHz}$ e Jovem Pan - 620 kHz).

Em geral, elas têm o mesmo tipo de espaços destinados à participação popular, vinculados aos pedidos musicais, às perguntas para especialistas, às enquetes e às opiniões sobre temas pré-fixados. Os espaços são maiores nas populares que nas

${ }^{97} \mathrm{O}$ acompanhamento foi feito nos seguintes períodos: AMs, de 17 a 30/09/07 e FMs de 1 ㅇ a 14/10/07. 
jornalísticas. Em relação às FMs, oferecem participações mais longas e é comum o público falar de suas histórias, problemas etc.

A primeira colocada no ranking, Globo $A M^{98}$, faz parte do sistema Rádio Globo Brasil cujo slogan é "A estrela maior é você". A programação da emissora é, em grande parte, a da rede (três emissoras e 27 afiliadas), com alguns programas próprios. A emissora surgiu em 1959 como Rádio Nacional e passou a se chamar Globo na segunda metade da década de 70 .

A participação do público é a tradicional, com envio de perguntas, pedidos musicais, participação em enquetes, concursos etc. Essas participações estão espalhadas em vários programas como "Quintal da Globo" - veiculado de domingo a sexta-feira, às 20 h. O programa traz notícias curiosas, estilo tablóide e músicas no "Jogo do cabe tudo", em que os ouvintes ligam e pedem músicas dos anos 70, 80 e 90. A disputa é com a equipe de produção do programa que tenta atender aos pedidos. Os ouvintes participam por telefone. O programa também permite aos ouvintes fazer perguntas para especialistas sobre diversos temas. As perguntas são lidas pelo apresentador.

A fórmula da participação ligada a concursos é aplicada também em "Enquanto a bola não rola", aos domingos, às $12 \mathrm{~h}$.

Já o modelo do "consultório", em que os ouvintes tiram suas dúvidas com especialistas é a tônica de "Com a palavra, o professor Pasquale", em que são respondidas questões sobre a língua portuguesa. Os ouvintes são identificados com o nome completo e a cidade. O programa é veiculado de segunda a sexta, às $11 \mathrm{~h}$, com menos de 3 minutos de duração.

${ }^{98}$ http://globoradio.globo.com/MusicCenter/0, ,4864, 00.html 
No programa "Momento de Fé", de segunda a sábado, das 9 às $10 \mathrm{~h}$, com Padre Marcelo Rossi, os ouvintes são convidados a dar testemunhos sobre vários temas que são abordados no programa.

Os ouvintes também são convidados a dar sua opinião sobre um tema anunciado no quadro "Pesquisa do Dia" em "Manhã da Globo (São Paulo)" - de segunda a sábado, às $10 \mathrm{~h}$. As participações são gravadas e depois algumas selecionadas são veiculadas pelo programa. O mesmo programa abre espaço para que os ouvintes ensinem receitas de culinária.

No programa "Se liga, Brasil", de segunda a sábado, às $13 \mathrm{~h}$, os ouvintes participam por telefone, ao vivo, mandando mensagens e comentando o programa.

Mas o espaço em que as histórias pessoais de ouvintes são melhor apresentadas é "Prazer em aprender" - de Gilberto Dimenstein. O programa, de cerca de três minutos de duração, fala de anônimos e famosos que descobriram o prazer de aprender através de atitudes e projetos das escolas. Traz trechos de entrevistas do personagem central da história. Os leitores podem encaminhar suas histórias que, se selecionadas, são levadas ao ar aos sábados, às $11 \mathrm{~h}$.

A segunda colocada, a Capital $\mathrm{AM}^{99}$, foi lançada em 1978, no dia do aniversário da cidade de São Paulo e é, das rádios pesquisadas, a que mais oferece espaços para o público participar.

"A Hora da Saudade", com José Carlos Gomes (veiculado de segunda a sexta, das 17 às $19 \mathrm{~h}$ e das 21 às $0 \mathrm{~h}$ ) traz, na voz do apresentador, mensagens de ouvintes comentando o programa e fazendo pedidos e oferecimentos musicais.

${ }^{99}$ http://www.radiocapital.am.br 
O programa "Paulo Barboza", veiculado de segunda a sexta, das 8 às 11 h, e aos sábados, das 9 às 12 h, é um dos mais interativos da emissora. O programa traz vários quadros com a participação do público. Em "Torcida do Paulo Barboza", os ouvintes gravam mensagens em uma secretária eletrônica sobre qualquer assunto. São comuns anúncios de venda e serviços, numa espécie de classificados radiofônicos gratuitos. Em "Carta da Fé", o apresentador narra um milagre enviado pelas ouvintes. A narrativa é feita em primeira pessoa como se a própria pessoa estivesse contando sua história. Depois da leitura da história, o apresentador conversa, ao vivo, por telefone, com a ouvinte, emendando com o quadro "Corrente de Amor", com a participação do Padre Juarez de Castro, onde a participação do público continua, e são feitas bênçãos. O programa traz ainda vários quadros com prêmios, sendo que em "Varinha Mágica" o ouvinte conta sua história por telefone ao vivo e fala de um sonho que pode ser realizado pelo programa. Vale tudo: de uma festa de 15 anos a capacetes de moto. Já em "Recados do Coração", uma ouvinte conta seu problema (sem precisar se identificar) e depois as outras ouvintes ligam e conversam com a protagonista, dando conselhos e também contando suas experiências. Tudo ao vivo.

O apresentador Eli Correa, com o programa que leva seu nome, é o que fica mais tempo no ar na emissora: de segunda a sexta, das $5 \mathrm{~h} 30$ às $8 \mathrm{~h}$ e das 13 às 16 h; e sábado, das $5 \mathrm{~h} 30$ às 9 $\mathrm{h}$ e das 12 às $14 \mathrm{~h}$. Em seu programa, muito da participação está vinculada ao jornalismo de serviço como no quadro "Repórter do Povo" em que o público apresenta seus problemas em relação à cidade (transporte, segurança etc.). Mas é o quadro "Que Saudade de Você", veiculado às $14 \mathrm{~h}$, que merece maior destaque. Durante cerca de 30 minutos, o apresentador interpreta uma carta enviada por um ouvinte narrando uma história de sua vida, sempre 
relacionada à saudade que sente de alguém ou de alguma situação. No programa de sábado na hora do almoço (“Vale a pena ouvir de novo"), ele reapresenta a melhor história de "Que saudade de você" da semana.

O "Programa da Cinthia" - de segunda a sexta, das 16 às $17 \mathrm{~h}$ - também abre espaço para os ouvintes falarem sobre os temas do dia e contarem suas experiências, por telefone. "Minha Cara Metade", "Verdade ou Mentira", "Receita dos Famosos" e "Quinta-Feira Mística" são alguns dos quadros abertos à participação.

A Bandeirantes $\mathrm{AM}^{100}$, a terceira colocada em audiência, foi criada em 1937 e tem seu foco no jornalismo. Seu slogan é "a rádio que briga por você".

Seus espaços para participação do público são mais tímidos que os das duas anteriores, principalmente no que se refere às histórias pessoais. A participação é mais vinculada às opiniões e comentários sobre os temas abordados e as notícias mais polêmicas do dia. O ouvinte repórter é restrito ao trânsito.

$\mathrm{Na}$ linha de quiz, a emissora mantém o "Desafio Bandeirantes", em que o apresentador Silvio Luiz submete um ouvinte a perguntas sobre esportes. O programa é veiculado de segunda a sexta (exceto em dias de jogos), às $21 \mathrm{~h} 30$.

O programa "Fanáticos por Futebol" (de segunda a sexta - exceto em dias de jogos, às $22 \mathrm{~h}$ ) traz perguntas de ouvintes que são respondidas pelos próprios apresentadores e por comentaristas. Na linha esportiva é comum a leitura de mensagens dos ouvintes com comentários e opiniões sobre temas diversos.

100 http://radiobandeirantes. terra.com.br/ 
Os radiojornais da emissora divulgam a "Pergunta do Dia" solicitando aos ouvintes que deixem suas mensagens sobre determinado assunto em uma secretária eletrônica. Depois as gravações são apresentadas nos vários programas.

Além disso, o "Manhã Bandeirantes" (de segunda a sexta, às $10 \mathrm{~h}$ ) mantém quadros para responder dúvidas de ouvintes como saúde de adolescentes e costuma falar sobre os emails recebidos dos ouvintes - em geral, elogiando a emissora.

No "Jornal em Três Tempos", de segunda a sexta, às 16 h, o destaque é para o ouvinte repórter com informações sobre o trânsito na Capital paulista. No "Bandeirantes Acontece", às 20h30, os ouvintes dão informações sobre as condições das estradas.

O humor traz em "Na Geral" (segunda a sexta, às 18h30) a participação de ouvintes para conversar, por telefone, ao vivo, sobre futebol com os apresentadores do programa.

Mas o grande espaço para o público contar suas histórias é o "Crônica do Ouvinte" apresentado às sextas-feiras, às $5 \mathrm{~h}$, dentro do programa "Grande Sampa" e reprisado no "Arquivo Musical" (domingos, às $6 \mathrm{~h}$ ). As histórias apresentadas concorrem num sorteio mensal a prêmios.

Jovem Pan $^{101}$ é a quarta AM de maior audiência na Grande São Paulo. Foi criada em 1944 e a exemplo da outra jornalística do grupo (Bandeirantes) oferece espaços mais restritos aos ouvintes, principalmente no que se refere às histórias pessoais.

Os ouvintes têm espaços para reclamar de serviços e produtos no "Jornal de Serviço" (de segunda a sexta-feira, às 9h30). As mensagens são lidas pelo locutor e o nome e cidade/bairro do ouvinte são informados. Várias mensagens são

${ }^{101}$ http://jovempan.uol.com.br/jpamnew/ 
lidas na seqüência. A fórmula é seguida também no Jornal da Manhã (segunda a sexta, às $5 \mathrm{~h}$ e aos sábados, às $5 \mathrm{~h} 30$ ) onde as mensagens dos ouvintes com queixas contra serviços públicos e empresas são lidas pelos locutores.

A mesma dinâmica é adotada quando os ouvintes mandam informações sobre o trânsito: as informações são dadas pelos repórteres e apresentadores.

Já no "Rádio ao Vivo", levado ao ar de segunda a sábado, às $22 \mathrm{~h} 30$, os ouvintes podem participar por telefone ao vivo, fazendo perguntas para os entrevistados, em geral especialistas de determinado assunto.

Na linha de programas esportivos, o "Jornal de Esportes" (segunda a sexta, às 11h30) faz uma questão para os ouvintes que deixam suas opiniões gravadas. Depois o programa exibe várias na seqüência.

O acompanhamento da rádio Tupi AM, a quinta colocada foi prejudicado em função da emissora não possuir site no período de realização da Pesquisa (agosto/setembro de 2.007). Assim, não foi possível predeterminar quais programas deveriam ser acompanhados e o critério adotado foi o de horário: foram acompanhadas as programações veiculadas das 6 às $12 \mathrm{~h}$, das 12 às $18 \mathrm{~h}$, das 18 às $24 \mathrm{~h}$, e das 24 às $6 \mathrm{~h}$, em dias diferentes ao longo da semana. Também foi acompanhada a programação de fim de semana em horários aleatórios.

No programa "Supertarde Tupi" com Rony Magrini, as ouvintes participam de um quiz e do quadro "História de Amor" em que o apresentador interpreta a carta de uma ouvinte contando sua história de amor. Além de repetir o formato do tradicional "Que Saudade de Você!" do programa Eli Correa, o quadro é também veiculado exatamente no mesmo horário: $14 \mathrm{~h}$. As diferenças ficam 
por conta do tempo (o quadro não ultrapassa 15 minutos contra os 30 de "Que Saudade de Você!") e da execução da música que marcou a história de amor no final da narração, elemento nem sempre presente em “Que Saudade de Você!".

Já no programa "Cícero Augusto", as ouvintes contam seus sonhos (por correspondência ou telefone) e o apresentador os interpreta, inclusive sugerindo números para jogo. As ouvintes grávidas também escrevem e o apresentador "advinha" qual será o sexo do bebê.

Entre as FMs de maior audiência, três (Nativa, Mix e Band) têm programação popular, uma (Tupi) é voltada à música sertaneja e uma (Transcontinental) a ritmos da cultura afro.

Todas, a exemplo do observado nas AMs, concentram a maior parte das participações do público a promoções, pedidos musicais e enquetes. Mas sua característica menos falada e mais musical inibe os depoimentos mais longos e restringe os espaços a participações curtas.

A líder de audiência, Nativa ${ }^{102}(95,3 \mathrm{MHz})$, estreou em 1998 em São Paulo e traz vários programas que permitem a participação do público ainda que sem grandes possibilidades de autoria.

Na linha de consultório, o quadro "Segredos da Fátima", que vai ao ar dentro do programa "Paixão Nativa" (da meia-noite às $2 \mathrm{~h}$ ), responde a dúvidas dos ouvintes sobre sexo $\mathrm{e}$ relacionamento.

Mas o mais forte na programação da emissora é o envio de recados de ouvinte para ouvinte nos programas "Paixão Nativa"

102 http: //www.nativa.com.br/ 
(em duas edições: de segunda a sexta, das 12 às 13 h, e de domingo a sexta, das 22 às 02 h) e "Correio Elegante" (diariamente, das 14 às $15 \mathrm{~h}$ ). Grande parte dos recados é associada ao oferecimento de uma música.

Já a segunda colocada, Tupi $\mathrm{FM}^{103}$ (104,1 MHz), começou a trabalhar com a programação sertaneja em 1996. Das cinco FMs pesquisadas é a que mantém blocos maiores de programações musicais, muitas vezes com seqüências de quatro ou cinco músicas sem nenhuma interferência dos locutores/apresentadores, durante longos horários, na chamada "Programação Tupi FM" (de segunda a sexta, das 10 às $11 \mathrm{~h}$, das 13 às $19 \mathrm{~h}$, e das 20 às $22 \mathrm{~h}$; aos sábados, das 9 às $10 \mathrm{~h}$, das 14 às $19 \mathrm{~h}$ e das 20 às $21 \mathrm{~h}$; aos domingos, das 6 às $10 \mathrm{~h}$, das 14 às $19 \mathrm{~h}$, e das 20 às $24 \mathrm{~h}$ ). E no Expresso Tupi (diariamente, às $11 \mathrm{~h}$ ) que tem meia hora só de música.

\section{A Transcontinental ${ }^{104}(104,7 \mathrm{MHz})$ surgiu como uma} rádio especializada em samba e hoje já diversificou a programação, englobando também Black Music nacional e internacional, Axé, Funk e Forró.

O principal espaço para os ouvintes é a participação ao vivo pedindo músicas e concorrendo a prêmios dentro dos variados programas. É comum que o apresentador se lembre do ouvinte que está ligando e eles entabulem uma conversa de amigos. A emissora, apesar de ser tão bem colocada no ranking de audiência passa a idéia de um clube onde as pessoas se conhecem.

No programa "Cantinho Romântico" (segunda a sexta, às $12 \mathrm{~h}$ ), os ouvintes podem mandar recados românticos para outros ouvintes. Os melhores recebem prêmios. Esse estilo de

\footnotetext{
103 http://www. radiotupifm.com. br/

$104 \mathrm{http}: / /$ www.transcontinentalfm.com.br/index.asp?act=0\&id_area_site_wm =0
} 
"paquera no rádio" é a fórmula também do programa "Contatos Imediatos", veiculado de terça a sábado, às $2 \mathrm{~h}$. Recados românticos e seleções de ouvintes enviados por carta, fax, e-mail ou telefone é a fórmula de "Trans e Você", veiculado de segunda a sexta, às $23 \mathrm{~h}$.

$\mathrm{Na}$ linha das histórias pessoais, o principal espaço é "Esqueci de te Esquecer". O programa traz histórias enviadas pelos ouvintes narradas pelo apresentador Cid Luiz Jardim. O programa é veiculado de segunda a sexta, às 11 h30 e tem cerca de 10 minutos de duração.

A $\operatorname{Mix}^{105}(106,3 \mathrm{MHz})$ segue a mesma linha da Tupi FM, com longos horários de programação musical em que há muito pouca participação, quer do público, quer dos próprios apresentadores. E, repetindo o modelo das demais FMs, a participação do público é, em grande parte, realizada em concursos ou promoções.

Um dos principais games da emissora é o "Cadeira Elétrica" que põe os ouvintes num jogo de perguntas e respostas. Quem vence o desafio dentro do tempo de 60 segundos ganha prêmios.

A Band FM $^{106}(96,1 \mathrm{MHz})$ iniciou suas operações em 1975, mas adotou o tipo de programação atual em 1990. Seu slogan atual é "A sua rádio, do seu jeito!". A emissora mantém grandes horários quase que totalmente musicais, o que diminui os espaços para a participação do público. Nesses horários, os ouvintes têm apenas seus nomes citados quando ganham algum prêmio da emissora.

\footnotetext{
105 http://mixfm.ig.com.br/

106 http://www. bandfm.com.br/
} 
Já na "A Hora do Ronco" (segunda a sexta, às 6 h), os ouvintes mandam mensagens e podem participar por telefone. Apesar de falarem de vida íntima, tudo é feito em tom de brincadeira e gozação.

No "Love Songs" (domingo a quinta, às $22 \mathrm{~h}$ ), os recados dos ouvintes são gravados e veiculados, com sua própria voz, durante o programa. E no quadro "Momento Love Songs", uma carta de um ouvinte com uma declaração de amor é veiculada mas, logo no início, o apresentador já avisa que as cartas têm que ser editadas por causa do tempo do programa.

Entre as TVs com sinal aberto em São Paulo, selecionamos as quatro primeiras em audiência no painel nacional: Rede Globo; SBT - Sistema Brasileiro de Televisão; Rede Record; e Rede Bandeirantes ${ }^{107}$.

É inegável que, principalmente a partir dos anos 90, os espaços para o público e suas histórias pessoais foram ampliados na televisão. O espaço principal ocupado por esta programação é nos programas vespertinos, adaptações dos programas femininos, mas tratando de temáticas mais generalizadas. No entanto, o papel destinado à participação do público ainda é em grande parte o de platéia para os programas.

$\mathrm{Na}$ Rede Globo ${ }^{108}$, não são muito amplos os espaços destinados à participação do público e suas histórias pessoais.

\footnotetext{
107 Segundo dados do I bope de Junho de 2007 - www.ibope.com . Nos meses seguintes, SBT e Record disputaram acirradamente o segundo lugar. $O$ acompanhamento das programações foi feito no período de 3 a 16/09/07, mês em que a Record anunciava ter chegado à segunda posição isolada.

108 http://redeglobo.globo.com/
} 
$\mathrm{Na}$ área de entretenimento, o "Mais Você" apresentado por Ana Maria Braga e veiculado de segunda à sexta, às $8 \mathrm{~h}$, abre espaço para o público participar da platéia e das brincadeiras com prêmios.

A dupla platéia mais quadros com prêmios é a fórmula de participação também do "Caldeirão do Huck", com Luciano Huck, aos sábados, às 13 h. No quadro "Lata Velha", o personagem escolhido para participar tem sua história contada em uma entrevista com o apresentador. Já "Lar Doce Lar" apresenta a história de uma família que tem sua casa reformada pelo programa.

Em "Altas Horas", apresentado aos sábados, às $23 \mathrm{~h}$, Serginho Groissman abre espaço para a platéia fazer perguntas aos convidados e também veicula um quadro em que o público pode mandar recados para quem quiser.

O público como atração é a fórmula do “Domingão do Faustão". No quadro "Se vira nos 30", anônimos têm 30 segundos para demonstrar suas habilidades: vale tudo, imitações, malabarismo, mágicas. Mas é em "Curiosidades" que as histórias pessoais são mais exploradas. O quadro traz para o palco uma pessoa comum que tem uma história extraordinária.

Entre os infantis, o "TV Xuxa" (de segunda a sexta, às 9 h) faz um concurso pela internet entre os desenhos enviados pelas crianças. Os doze melhores são apresentados num painel no programa.

Na linha dos policiais, desde 1999, a emissora veicula Linha Direta. As histórias dos crimes (famosos e mais anônimos) são contadas a partir de dramatizações e depoimentos das testemunhas. Há também seções para divulgar criminosos foragidos. (MAIOR, 2006, p. 412) 
Nos programas jornalísticos, o espaço para as histórias pessoais de anônimos é totalmente vinculada à construção de personagens para reportagens. O recurso é usado mais abundantemente no "Jornal Hoje" (no ar, de segunda a sábado, às 13h15) e em programas como "Ação" (sábados, às 7h30) e “Pequenas Empresas \& Grandes Negócios" (domingos, às 7h30).

Mas a maior variedade dos espaços destinados ao público está na revista semanal "Fantástico", no ar nas noites de domingo desde 1973. Entre os quadros está "Central da Periferia", com Regina Casé, em que ela mostra a realidade de anônimos nas periferias de lugares tão diferentes como Paris, Luanda, Recife e Cidade do México. A exemplo de "Brasil Legal"109, o fio de condução das matérias é o humor.

Já em "Vc no Fantástico", são recebidos vídeos produzidos pelos telespectadores sobre assuntos propostos e, depois de uma seleção, alguns são exibidos no programa e/ou no site.

Mas o quadro que melhor explora na linguagem televisiva as histórias pessoais do próprio público é "Retrato Falado", com Denise Fraga, que estreou em 1999. Também conduzindo a narrativa através do humor, o quadro reinterpreta histórias que foram enviadas pelas próprias telespectadoras. Além da dramatização, a história é costurada pelo depoimento da autora. $O$ quadro pode ser encontrado também em DVD, com uma seleção de 15 histórias (DENISE FRAGA, 2000-2005) e em livro, com um breve histórico do programa, depoimentos de Denise Fraga e a seleção de 31 histórias narradas (FRAGA, 2005). Embora ainda conste da grade do "Fantástico" não tem sido exibido com

${ }^{109}$ Ver mais informações sobre o programa à p. 171. 
regularidade. Em 2007, apenas dois episódios novos foram veiculados.

A Globo é também a responsável no país pelo maior fenômeno de audiência entre os reality shows, o "Big Brother Brasil".

A Rede Record ${ }^{110}$ também oferece as opções tradicionais para participação do público em sua programação. Nos programas jornalísticos, a participação é vinculada aos personagens das reportagens, em particular no "Domingo Espetacular", revista semanal veiculada aos domingos, desde 2004.

Nos esportivos "Debate Bola" (segunda a sexta, às $12 \mathrm{~h}$ ) e "Terceiro Tempo" (domingos, às 23h15) é comum a leitura de mensagens do público.

$\mathrm{Na}$ linha dos reality shows, a Record veicula duas adaptações de programas internacionais: "O Aprendiz", com Roberto Justus que já está em sua quinta edição e "Simple Life mudando de vida", com Ticiane Pinheiro e Karina Bacchi, em sua primeira edição.

No "Hoje em Dia" (segunda a sexta, às 8h30), dois quadros trazem a participação popular em concursos: "Beleza na favela" seleciona adolescentes de comunidades carentes que disputam um book de modelo para tentar a carreira na área; e "Costureira nota 10" coloca duas costureiras em competição por um prêmio em dinheiro.

"Programa da Tarde" (segunda a sexta, às 15 h) traz o quadro "Cartão Postal" em que as telespectadoras enviam receitas em um cartão postal da própria cidade. As selecionadas são trazidas ao estúdio da Record para fazer o prato ao lado de Olivier

${ }^{110}$ http://www.rederecord.com.br/home.asp 
Anquier. O público pode ainda participar de diversas brincadeiras com direito a concorrer a prêmios.

$\mathrm{Na}$ fórmula de participação em jogos e games variados, os que oferecem maior espaço para o público são "Tudo é Possível" (aos domingos, às 13h30) e "O Melhor do Brasil" (aos sábados, às 15h30). Este último, apresentado por Márcio Garcia, permite ainda que o público envie suas histórias de vida e de amor para dois quadros do programa "História de Amor" e "Contra tudo e contra todos".

O $\mathrm{SBT}^{111}$ tem nas brincadeiras e jogos os principais espaços para participação de seu público. A tradição do canal vem do programa Sílvio Santos ${ }^{112}$ que ocupa os domingos com jogos, gincanas e concursos envolvendo a platéia e os clientes de seu "Baú da Felicidade". Entre os quadros estão "Qual é a Música?" (Domingos, às 14h15), com disputa entre artistas com a participação do público; "Você é Mais Esperto que um Garoto da Quinta Série?" (Domingos, às 15h45), um game de perguntas; e "Tentação" (Domingos, às 13h30), outro quiz com participação dos clientes sorteados.

Na mesma linha de Sílvio Santos, Celso Portiolli comanda "Curtindo com reais" (sábados, às $17 \mathrm{~h}$ ), com competições entre equipes adolescentes e "Curtindo com crianças" (sábados, às 15h15), com competições entre crianças e entre bebês.

A fórmula é a mesma no infantil "Bom Dia \& Cia", de segunda a sexta, às $9 \mathrm{~h}$, em que os telespectadores mirins participam das brincadeiras por telefone.

111 http: // www.sbt.com.br/

112 Mais informações à p. 165-6. 
No programa "Charme", com Adriana Galisteu, veiculado de segunda à sexta, às $16 \mathrm{~h}$, anônimos participam no palco de um quadro para encontrar namorados.

Na linha dos Reality Shows, a emissora mantém em sua grade três versões de produções internacionais: "Ídolos", de música, "Supernanny", de educação infantil, e "Quem perde ganha", de emagrecimento.

Nos jornalísticos, além da utilização de personagens nas reportagens, no "SBT Manchetes", de segunda a sábado, às $19 \mathrm{~h}$, com apresentação de Carlos Nascimento e Cynthia Benini, o público participa ao vivo por telefone dando sua opinião sobre um tema proposto pelo programa.

Mas o principal espaço para a participação do público e suas histórias pessoais é "Casos de Família", apresentado por Regina Volpato, de segunda a sexta, às $18 \mathrm{~h}$. O programa,

“...retrata a vida de cidadãos comuns com realidade e sensibilidade.

Diariamente, o programa traz temas do cotidiano que vão ressaltar as emoções dos participantes presentes no palco, da platéia convidada e dos telespectadores que estão em casa, resgatando valores sem apelar para provocações ou escândalos.

Os protagonistas de cada uma das histórias relatadas são pessoas anônimas que revelam seus sentimentos com sinceridade e verdade.

Além, dos convidados, a platéia também participa ativamente do programa com opiniões e perguntas sobre as histórias relatadas. A intenção é orientar e até mesmo solucionar os casos apresentados contando com a participação de um profissional especializado em comportamento." (CASOS DE, 2007)

Na página de inscrições, os interessados podem sugerir temas a serem abordados pelo programa que trata de um único assunto com vários participantes em cada edição. 
A Rede Bandeirantes ${ }^{113}$ também investe em competições e jogos com a participação do público em vários dos seus programas como "A Grande Chance", quiz apresentado por Gilberto Barros, as terças, às 22h30; e "Atualíssima", de segunda a sexta, às $14 \mathrm{~h}$, em que Leão Lobo e Patrícia Maldonado fazem um jogo com os telespectadores no quadro "Celebridades".

No jornalismo, o público participa de "São Paulo Acontece", apresentado por Flávia Cavalcante, de segunda a sexta, às $13 \mathrm{~h}$, respondendo à "Pergunta do dia", e também de "Brasil Urgente", apresentado por José Luiz Datena, de segunda a sexta, às $18 \mathrm{~h}$, através de enquetes na rua, telefone, e-mail ou o tradicional correio.

"Brasil Urgente", que estreou em 2001, traz o cidadão anônimo também como personagem de suas matérias, mas sempre na perspectiva da tragédia:

"Os sujeitos populares de Brasil Urgente, sujeitos das táticas, enredados pelos textos da televisão, contextos de violência e carência, trazem para a praça pública de Brasil Urgente as contradições da vida social. Sem espaço próprio, falando sobre temas grotescos, hibridizando a cena midiática, esses sujeitos chamam a atenção para o equilíbrio precário de diferentes questões da sociedade brasileira." (LANA, 2006, grifos da autora)

No entanto, é no programa "Márcia" que as histórias pessoais do público têm mais destaque. Apresentado por Márcia Goldschmidt, de segunda a sexta, às $16 \mathrm{~h} 30$, o programa:

“...leva ao telespectador emocionantes histórias de vida. MÁRCIA mostra os dramas de pessoas comuns em busca de soluções para seus problemas. Paixões, traições, desencontros e muito mistério em um programa diário e ao vivo.

Diante de uma platéia de aproximadamente 100 pessoas, Márcia entrevista convidados e leva

113 http://band.com.br/home.asp 
profissionais como psicólogos e advogados para ajudar no desfecho de cada caso. Um programa dinâmico e ousado que, além de entretenimento, leva informação e orientação aos telespectadores." (MÁRCIA, 2007) 


\section{Mídia Digital}

Ao falarmos da Mídia Digital estamos englobando também um conjunto de tecnologias de distribuição de informação por meio digital e de plataformas/sistemas, ao invés de simplesmente um meio de comunicação específico. Temos que levar em conta, inclusive, que até mesmo meios tradicionais como rádio e televisão deverão trocar sua plataforma eletrônica por outra digital nas próximas décadas. No entanto, ao falarmos em Mídia Digital, sempre associamos com a internet e nela, a web (abreviação para World Wide Web - em português, teia), uma espécie de carro chefe do conjunto. E é especificamente sobre as experiências na Internet/Web com as histórias pessoais do público que falaremos aqui.

Outro ponto importante é que, neste capítulo, não haverá a divisão entre as experiências históricas e o quadro atual já que estamos abordando uma mídia que tem pouco mais de dez anos de abertura ao grande público e onde, portanto, passado e presente são praticamente a mesma coisa. Assim, ao falarmos das características da participação do público na internet e dos espaços para as histórias pessoais, optamos por reunir as experiências mais significativas levantadas independentemente de permanecerem ou não no ar.

No entanto, apesar de seu pouco tempo de existência, foi a partir da internet que a promessa da bidirecionalidade da comunicação, feita na criação do rádio, pôde se concretizar e a Indústria da Interatividade teve as condições mais propícias para se implantar e expandir, impactando todo o sistema midiático. 
Não se pode negar que, se aconteceram antes várias experiências de interatividade e participação do público nos diversos meios de comunicação, foi com a criação da internet que essas práticas passaram a ser sistematizadas e divulgadas como diferenciais dos meios.

A origem do processo está nos próprios objetivos de criação da rede. A internet vem do trabalho da Agência de Projetos de Pesquisa Avançada (ARPA) do Departamento de Defesa norteamericano que nos anos 60 e 70 buscava um dispositivo de comunicação que, em caso de guerra, fosse capaz de resistir ao ataque às bases interligadas. Por isso havia a necessidade de uma rede em que não houvesse um centro determinado possibilitando que, na ausência de funcionamento de um dos pontos, os demais continuassem interligados e se comunicando. A tecnologia desenvolvida foi a base da Arpanet que iniciou seu funcionamento em 1969 ligando quatro universidades americanas que colaboravam com a agência (ESPINOZA, 2000, p. 19-20). A expansão vem com a adoção de um protocolo que permitiu a qualquer tipo de computador se conectar à rede, chamado de TCP/IP (Transmission Control Protocol/Internet Protocol). O nome internet foi adotado em 1982 (TORQUE, 2007).

Em 1990 foi a vez de Tim Berners-Lee, do Laboratório do Centro Europeu de Física (CERN), propor um sistema global de hipertexto que utilizasse a estrutura da internet. Em 1994 surgiu a www (sigla para World Wide Web). (ESPINOZA, 2000, p. 21-22)

Mas a internet só foi aberta comercialmente em 1995, quando empresas da iniciativa privada começaram a controlar o 
tráfego não acadêmico. No Brasil, também em 1995, a Embratel ativou o primeiro backbone ${ }^{114}$ comercial. (TORQUE, 2007)

A falta de um centro, necessidade que gerou a criação da internet, é também um fator limitante se pensamos em termos de conhecimento e documentação das experiências realizadas na rede. Ao mesmo tempo permite que o tráfego da comunicação se dê em vários sentidos, rompendo com o modelo unidirecional.

Além disso, a falta de limitações espaciais do novo meio, em contraposição às dificuldades de espaço vividas pelas mídias anteriores $^{115}$, possibilita uma profusão maior de conteúdos veiculados.

Segundo MANDEL; SIMON; DELYRA (1997, p. 13):

"Embora informação tenha sido sempre um elemento útil, a tecnologia recente permitiu pela primeira vez que se armazenasse e tratasse grande volume de dados, e que se comunicassem esses dados em grande velocidade em qualquer distância".

O barateamento dos custos para publicar conteúdos principalmente em relação aos outros meios de comunicação também permite que um número maior de autores aventure-se na missão de divulgar informações e conteúdos variáveis.

Desde o início da rede, multiplicaram-se as experiências em que sites, inicialmente domésticos com propostas de conteúdos alternativos, acabaram se tornando fenômenos na internet.

Com isso, podemos perceber que a comunicação na nova mídia já nasce bidirecional e o público, antes tratado como

${ }^{114}$ Em português, espinha dorsal. O backbone é o trecho de maior capacidade da Internet que conecta vários pontos da Rede. No Brasil, foi a RNP (Rede Nacional de Pesquisa) que criou o primeiro backbone para atender entidades acadêmicas que queriam conectar-se à Rede.

${ }^{115}$ Se os meios impressos sofrem pela limitação que a quantidade de páginas impõe ao conteúdo, os meios eletrônicos têm a limitação do tempo, que age como um espaço delimitador para a programação. 
receptor, vai, rapidamente, buscar estabelecer para si novos espaços quer dentro das estruturas das empresas de mídia, quer na comunicação direta.

Para GILLMOR (2005, p. 227, grifos do autor):

"A Internet é o mais importante meio de difusão desde a invenção da imprensa. Substitui tudo o que havia antes e é, da maneira mais radical, promotora da transformação. Quando qualquer um pode ser escritor, no sentido mais amplo e para um público global, muitos de nós tentaremos sê-lo. A Net está a desmentir tantas das coisas que dizíamos acerca dos media e dos modelos empresariais que mal conseguimos acompanhar as transformações; é difícil manter o equilíbrio quando está em curso a passagem de um hierarquia vertical para algo de muito mais democrático e, é certo, confuso."

Essa mudança na relação entre público e autor tem levado a algumas discussões acerca da internet ser ou não um meio de comunicação. SAAD (2003, p. 116, grifos da autora) explica o conflito existente através do depoimento do jornalista norte-americano Michel Wolff:

"Recentemente, tive uma desagradável premonição: ' $E$ se a web, a internet e tudo o mais não fosse mídia?' . Há quatro anos, quando do surgimento do ciberespaço, virtualmente todo mundo, e não apenas os executivos da tecnologia da informação, dizia: ' Uau! Uma nova tecnologia de comunicação! Deve ser mídia! Uma nova mídia!'.

Existia uma falha na lógica da época, mas não me lembro de ninguém questionando isso. Mas, hoje, isso me parece um grande erro, pois o telefone também foi uma tecnologia de comunicação e jamais foi elevado à categoria de mídia.

Depois disso, por um bom tempo, perguntei a colegas jornalistas sobre qual era sua definição de mídia e se a internet era um negócio de mídia. A maioria das pessoas não considerou isso como uma questão central, e a resposta em geral era 'chame a internet do que você quiser!'.

A minha profissão, ou aquilo que poderia chamar de meu conjunto de habilidades, é construir opiniões e textos, ou perfis que, de uma maneira ou outra, 
mobilizem um grupo de pessoas interessadas em saber o que penso e falo. Algumas podem até pensar sobre como eu gostaria de transformar suas opiniões.

Colocado assim, poderíamos pensar que estamos num negócio de manipulação. E de certa forma é (...) mas a mensagem, seja qual for a sua legitimidade e credibilidade, é enviada de uma forma mais ou menos coerente para que possa ser entendida, com a cara do emissor.

Algo fundamentalmente diferente disso ocorre com a internet. Não tenho a certeza de que duas pessoas saiam de uma navegação com o mesmo nível de experiências acerca de uma informação. Diferente do telefone, a internet é um instrumento através do qual todos nós podemos ter um individualista e idiossincrático controle sobre as mensagens."

Para MONTEIRO (2001, p. 31, grifos do autor), são quatro as características que definem um meio de comunicação:

“a) são operados por organizações amplas e complexas, envolvendo diversos profissionais, com diferentes habilidades;

b) são capazes de difundir suas mensagens para milhares ou até milhões de pessoas, utilizando grandes recursos tecnológicos (os veículos de massa), sustentados pela economia de mercado (através da publicidade, principalmente);

c) falam para uma audiência numerosa, heterogênea, dispersa geograficamente e anônima;

d) e, principalmente, exercem uma comunicação de um só sentido, ainda que possuam algum sistema de feedback (índices de audiência, por exemplo)."

Para ele, a internet reúne, ainda que sob determinada medida (os portais, por exemplo) as três primeiras características. No entanto, a comunicação pela rede é intrinsecamente bidirecional, tornando-a um meio híbrido:

"Portanto, poderíamos dizer que a internet é uma espécie de meio 'híbrido': embora criado como meio de comunicação interpessoal, tem características de meio de comunicação de massa." (MONTEIRO, 2001, p. 32, grifos do autor)

Na verdade, mesmo as características relacionadas à difusão de sua mensagem para milhares ou até milhões de 
pessoas, numa audiência numerosa só pode ser aplicada à internet enquanto capacidade e não resultado. Afinal, o ciberespaço é significantemente um espaço público, permitindo a qualquer um veicular suas mensagens diretamente só que, na maioria dos casos, para públicos extremamente reduzidos.

Pesquisa de 2007 da Datafolha, por exemplo, mostra que $42 \%$ dos 49 milhões de brasileiros que utilizam a internet já publicam conteúdo próprio (YONAHA, 2007). E esse índice é maior entre os mais jovens: $61 \%$ dos internautas entre 16 e 24 anos já publicaram algum conteúdo na web. Os motivos elencados para colocar conteúdo próprio na rede foram: 1을 relacionar-se com as pessoas/amigos (33\%); 2ㅇ) Divulgar um trabalho/trabalho cultural de autoria própria (7\%); 3) Ilustrar ou contar um fato, história ou notícia na internet $(5 \%)$. No entanto, as grandes audiências continuam vinculadas a poucos produtores ligados a grandes conglomerados de mídia.

Para MEDITSCH (1999, p. 212), o papel reservado ao público no novo meio é o de sujeito-receptor e não propriamente o de um emissor já que a maioria veiculará seus conteúdos para audiências baixíssimas, enquanto os grandes fluxos de público continuarão concentrados nos mesmos emissores de sempre, os que detém os meios sofisticados de produção.

No entanto, o próprio GILLMOR (2005, p. 143, grifos do autor) destaca que, mais importante que o resultado em termos de audiência da atuação do público está a possibilidade de, pela primeira vez, se dar voz diretamente a ele, praticamente sem mediação:

"A cobertura de importantes eventos por jornalistas não profissionais é apenas uma parte da questão. O que também interessa é o facto de as pessoas terem oportunidade de falar. É um dos mais saudáveis 
melhoramentos nos media desde há muito tempo. Estamos a ouvir novas vozes - não necessariamente de indivíduos que desejem ganhar a vida a falar em público, mas de pessoas que pretendem dizer o que pensam e o que ouviram, mesmo que só possam falar para uns poucos."116

Segundo SAAD (2003, p. 25-6), abordar a internet com os critérios adotados nas mídias tradicionais é perder o foco sobre as possibilidades trazidas pelo novo meio:

"O uso da internet pelo mercado informativo teve como premissa o entendimento de que a grande rede surgia como mais uma mídia e, como tal e similar aos demais meios de disseminação de mensagens, deveria resultar num negócio lucrativo. Ficaram em segundo plano os aspectos mais significativos das redes digitais de comunicação e informação: uma tecnologia bidirecional que coloca produtor e receptor da informação no mesmo patamar; que possibilita diálogos interpessoais e intergrupais sem a intervenção do produtor da informação; com potencial de uso não apenas de distribuição e captação de informações, mas também de gerenciador de dados e criador de sentido para grupos de usuários de qualquer porte."

No mercado informativo, o The San Jose Mercury News criou um serviço de informação jornalística em 1985 que é tido como pioneiro no mundo online. Já o New York Times foi o primeiro jornal do mundo a estrear sua versão online ainda nos anos 80 . A versão online da edição impressa do The San Jose Mercury News foi implantada em 1993.

No Brasil, dois jornais disputam o pioneirismo na web. 0 Jornal do Comércio, de Recife/PE, em dezembro de 1994, passou a disponibilizar online diariamente a primeira página de sua versão impressa e semanalmente, os cadernos de informática e meio ambiente. Já o Jornal do Brasil, do Rio de Janeiro, colocou sua edição completa online em maio de 1995.

${ }^{116}$ Como o livro é uma edição portuguesa, respeitamos a grafia original. 
No mesmo ano (1995), a Folha de S. Paulo iniciou seu trabalho de veicular pela internet notícias da sua edição impressa, num projeto intitulado Folha Web. No entanto, o portal do grupo Folha, o Universo Online (UOL) só foi entrar no ar em abril de 1996, ainda que na época não fosse exatamente um portal. Segundo Caio Túlio COSTA (2007,p. 10, grifos do autor), fundador do UOL, a demora em colocar o serviço no ar deveu-se em parte, por sua insistência em estrear já com o bate-papo em funcionamento:

“Tanto fizemos que o bate-papo ficou redondo e o serviço estreou na madrugada de 29 de abril de 1996. Sucesso absoluto! Cada pessoa que entrava em uma das salas recebia uma salva de palmas na pequena salinha, onde acompanhávamos os ambientes de chat conectados então por um 'velocíssimo' modem de 33,6K. Exibíamos como troféus as poucas salas com os poucos internautas escondidos por apelidos (nicknames), todos trocando conversa sobre tudo e nada. Como as pessoas gostavam daquilo!"

O desenvolvimento desses portais representou a incorporação e valorização de diversas outras ferramentas tidas como interativas até a recente consolidação da adoção de espaços para a prática do Jornalismo Colaborativo. O modelo, embora apareça também em outras mídias, tem se expandido a partir da internet:

"Tudo se resume a algo muito simples: os leitores (ou telespectadores, ou ouvintes) sabem mais que os profissionais dos media. Uma verdade por definição: eles são muitos e nós, nas mais das vezes, somos um só. Necessitamos de reconhecer o que é óbvio e, no melhor sentido da palavra, valer-nos dos conhecimentos deles. Se o não fizermos, mas os nossos antigos leitores verificarem que não têm de contentar-se com informações mal cozinhadas, poderão decidir irem eles mesmos para a cozinha. (...) A Internet é o primeiro meio de informação de que o público é o proprietário, o primeiro meio que deu voz ao público." (GILLMOR, 2005, p. 119 , grifos do autor) 
E mais à frente:

"Na verdade, as bases estão a transcender as reacções anémicas contra a produção e o consumo de informação que caracterizaram os últimos cinquenta, ou mais, anos. Pela primeira vez na história moderna, o utilizador está no comando, como consumidor e como produtor." (GILLMOR, 2005, p. 141-2)

No entanto, os espaços oferecidos estão vinculados exclusivamente às informações, limitando as possibilidades de autoria. A idéia é que cidadãos se tornem repórteres.

A origem dessa idéia na internet é atribuída ao Slashdot ${ }^{117}$, fundado em 1997 por um estudante americano de 21 anos, Rob Malda. O site sobre tecnologia foi vendido em 1999 e hoje pertence à OpenSource Technology Group. (LEAL, Renata, 2007)

Com uma proposta mais geral, está o OhmyNews ${ }^{118}$, fundado pelo sul-coreano Oh Yeon Ho em 2000. O site dispõe de uma equipe de jornalistas que edita o material enviado pelos milhares de colaboradores de todo o mundo. Os participantes recebem pelas colaborações aproveitadas. (TIRABOSCHI, 2007)

Além de enviar informações, muitas vezes cabe aos próprios internautas a definição de quais assuntos/matérias devem ou não ter destaque no site. O site de cultura brasileira Overmundo $^{119}$ é um exemplo concreto dessas experiências. Os interessados submetem suas contribuições primeiramente à Sala de Edição onde outros usuários registram comentários e sugestões para melhorar o texto que podem ou não ser incorporados pelo autor. De lá, o texto vai para a Sala de Votação por 48 horas. É

\footnotetext{
117 http: //slashdot. org/

118 http://english.ohmynews.com/

119 www.overmundo.com.br
} 
pelo resultado dessa votação que a colaboração poderá ser parte das seções de Overmundo.

A própria natureza da leitura nos meios digitais tem forte influencia neste modelo de cooperação em textos. Segundo CHARTIER (1999, p. 90-1):

"O novo suporte do texto permite usos, manuseios e intervenções do leitor infinitamente mais numerosos e mais livres do que qualquer uma das formas antigas do livro. No livro em rolo, como no códex, é certo, o leitor pode intervir. Sempre lhe é possível insinuar sua escrita nos espaços deixados em branco, mas permanece uma clara divisão, que se marca tanto no rolo antigo como no códex medieval e moderno, entre a autoridade do texto, oferecido pela cópia manuscrita ou pela composição tipográfica, e as intervenções do leitor, necessariamente indicadas nas margens, como um lugar periférico com relação à autoridade. Sabe-se muito bem (...) que isto não é mais verdadeiro. O leitor não é mais constrangido a intervir na margem, no sentido literal ou no sentido figurado. Ele pode intervir no coração, no centro. Que resta então da definição do sagrado, que supunha uma autoridade impondo uma atitude feita de reverência, de obediência ou de meditação, quando o suporte material confunde a distinção entre o autor e o leitor, entre a autoridade e a apropriação?"

Completamente diferente dos meios tradicionais, a não linearidade oferecida pelos meios digitais proporciona que a chamada experiência de navegação nunca seja igual para dois internautas. Isso resulta na principal dificuldade da idealização de produtos comunicacionais para a internet que é o conhecimento dos usuários e, ao mesmo tempo, reforça a necessidade de afinar os canais e possibilidades de bidirecionalidade da comunicação.

“Na verdade, não existe um único modelo de comportamento do usuário, porque cada um usa a web de uma forma diferente, em diferentes momentos do dia e, talvez, de diferentes lugares, condicionando seu próprio comportamento.

Da impossibilidade propomos a proximidade. Quanto mais próxima ao usuário a operação digital se posicionar, permitindo um relacionamento 
individualizado, melhor essa operação irá corresponder em termos de competição. É decisivo, portanto, estabelecer um movimento constante, ordenado e dialógico na direção do usuário." (SAAD, 2003, p. 254)

A influência deste modelo já é visível na página principal dos principais portais brasileiros. Dos três principais apenas o $\mathrm{UOL}^{120}$ não mantém uma seção fixa para essas contribuições em sua homepage, embora também aceite as participações. No Terra $^{121}$, a seção é chamada "Vc Repórter" e inclui textos, fotos e vídeos enviados pelos internautas. Já no $1 \mathrm{G}^{122}$, o espaço “Minha Notícia" aceita textos e/ou fotos e já completou seu primeiro aniversário (em julho de 2007). O espaço do IG é o maior dos portais brasileiros.

O G1 (canal de notícias do portal Globo.com) também recebe colaborações do público na seção "Vc no Gl" e seu diferencial é que não é restrito a notícias. Há espaços para fotos pessoais ainda que relacionadas a temáticas propostas pelo site (como, por exemplo, "Vc grávida", com fotos e relatos de leitoras esperando seus filhos ou o Especial de Dia das Mães de 2007 com as fotos enviadas pelas internautas que comemoravam pela primeira vez a data).

"Nessa expressão de criatividade das massas, é notável como os sujeitos participantes dessas redes tornam-se ao mesmo tempo agentes e produtores de interferências comunicacionais capazes de influir sobre hábitos e formas de percepção estética." (FONTANELLA; PRYSTHON, 2004, p. 7)

Esses sites jornalísticos acabam se caracterizando como comunidades virtuais, onde várias pessoas de pontos remotos se reúnem em um ambiente colaborativo para troca de informações e experiências.

\footnotetext{
120 www.uol.com.br

121 wwW.terra.com.br

122 www.ig.com.br
} 
O conceito foi desenvolvido em 1993, quando Howard Rheingold publicou "Virtual Community" falando de sua experiência com a comunidade The WELL, considerada uma das pioneiras do mundo. A WELL, abreviação para Whole Earth'Letronic Link, surgiu em 1985, reunindo, segundo sua homepage, "escritores, programadores, jornalistas, ativistas e outras pessoas criativas" (THE WELL, 2007, tradução nossa).

Para Rheingold,

"As comunidades virtuais - uma experiência social não planejada - são os agregados sociais surgidos na Rede, quando os intervenientes de um debate o levam por diante em número e sentimento suficientes para formarem teias de relações pessoais no ciberespaço (espaço conceptual onde se manifestam palavras, relações humanas, dados, riqueza e poder dos utilizadores da tecnologia de CMC)." (RHEINGOLD, 1996, p. 18) ${ }^{123}$

A troca de experiências, relatos, informações que sustentam as comunidades estabelecem a relação entre os participantes (em particular os mais presentes), propiciando um sentimento de pertencimento. É esse sentido que irá favorecer o caráter colaborativo e diferenciá-lo de um simples agrupamento. Segundo PALÁCIOS (1995, p. 101), os elementos básicos das comunidades são:

"o sentimento de pertencimento; uma territorialidade (geográfica e/ou simbólica) definida; a permanência; a ligação entre sentimento de comunidade; caráter cooperativo e emergência de um projeto comum; a existência de formas próprias de comunicação; a tendência à institucionalização"

O maior fenômeno entre as comunidades no Brasil foi o Orkut $^{124}$, uma espécie de comunidade-portal de relacionamento que permite a troca de informações pessoais entre usuários e a

\footnotetext{
${ }^{123}$ O autor usa CMC para se referir a "Comunicação Mediada por Computador"

${ }^{124}$ www. orkut.com
} 
criação e participação em inúmeras comunidades, dentro do espaço maior, sobre os assuntos de interesse dos próprios internautas. Criado pelo Google em 2004, ganhou uma versão em português em 2005 já que o Brasil chegou a ser o país de origem de $75 \%$ de seus membros. Em 2007, o Brasil era responsável ainda por mais de $53 \%$ dos membros da comunidade.

"É, portanto, pela mediação das tecnologias digitais que os indivíduos trocam informações e se comunicam, produzindo uma trama de sentidos sobre si, sobre os outros e sobre o mundo. Em torno dos valores que the são próprios, os grupos sociais dão forma a seus territórios, a suas ideologias, às suas tribos, formando redes baseadas em afinidades." (FLORIANI; MORIGI, 2006, p. 5-6)

Muitas vezes, as relações estabelecidas ultrapassam as fronteiras do virtual, como é o caso do "Viva SP"125. A comunidade virtual criada por ocasião do 450 ㅇ aniversário de São Paulo, além de permanecer publicando novos depoimentos/relatos, também organiza encontros presenciais para visitas a bairros ou pontos de interesse da Cidade. Além disso, migrou também para o rádio com boletins transmitidos pela Rádio Eldorado (na FM os boletins ficaram até 2004 e na AM continuam sendo transmitidos até hoje).

O Museu da Pessoa ${ }^{126}$ foi outra comunidade que casou a experiência da internet com o rádio. O Museu foi fundado em 1991, inicialmente captando histórias narradas pelos próprios autores (em sua maioria anônimos) em cabines de gravação. Em 1996 tornou-se um site e um ano depois começou a receber também contribuições online (NOSSA HISTÓRIA, 2007). Em 2002 passou também a adotar uma estratégia multimídia com a veiculação pela Rádio Cultura AM do programa “O Museu da Pessoa - a Memória do

\footnotetext{
125 www. vivasp.com

${ }^{126}$ www. museudapessoa.com.br
} 
Cidadão", com cerca de 3 minutos de duração. (ROCHA, 2004, p. 46-52)

"Ao contar a própria história, a pessoa se coloca no centro do universo tanto quanto o público numa platéia que ouve um repentista se põe no espaço sonoro e é inundado pelo som que o circunda e faz da sua posição, seja ela qual for, um novo centro. Mas o repentista também é um centro do qual emanam vibrações sonoras para todos os lados, tal qual na tradição oral, quando aquele que fala torna-se o centro das atenções, o biografado se torna o ponto central do mundo construído nas páginas do Museu da Pessoa quando a sua história é lida." (ROCHA, 2004, p. 67)

O fenômeno das comunidades virtuais está associado ao produto formado pelo conjunto das contribuições que podem ser acompanhadas individualmente, mas que reunidas representam um universo mais rico.

"Ainda que outras janelas se abram no desktop, apenas uma pode ser lida por vez, (...) mas simultaneamente existe o movimento que integra em conjunto todas as janelas possíveis de serem abertas, pois se uma história é aberta e fica à espera de ser lida, enquanto outra recebe esta atenção, ela de certa forma também se torna parceira da primeira..." (ROCHA, 2004, p. 67)

As comunidades virtuais, mais que possibilitar, procuram incentivar os diversos usuários à prática da autoria em seus ambientes. O reforço a esta participação é feita através de diversas ferramentas como a Identidade (que permite que o usuário seja identificado pelo grupo) e o Karma (em que são medidos o tempo e o volume de participação) (SPYER, 2007, p. 37). Essas ferramentas irão reforçar as principais motivações para participar ativamente de uma comunidade que, segundo SPYER (2007, p.36, grifos do autor), são:

"Reciprocidade: Uma pessoa fornece informação relevante para um grupo na expectativa de que será recompensada recebendo ajuda e informações úteis no futuro. Há registros indicando, por exemplo, que 
participantes ativos de comunidades virtuais recebem respostas mais rápido do que desconhecidos. Da mesma maneira, uma pessoa que apenas pede e não oferece ajuda aos outros acaba ignorada dentro da comunidade.

Prestígio: Para ser respeitado e reconhecido dentro de um determinado grupo, um indivíduo pode oferecer informações de qualidade, fartura de detalhes técnicos nas respostas, apresentar disposição para ajudar os outros e redação elegante. Em função do prestígio, é comum que usuários que atuam em uma comunidade incrementem sua participação ao receberem um título diferenciado, como o de líder ou moderador.

Incentivo social: O vínculo a um determinado grupo leva pessoas a oferecerem voluntariamente ajuda e informações. Isso vale, por exemplo, para alunos e ex-alunos de uma escola ou universidade, torcedores de um time, freqüentadores de um estabelecimento comercial, entre várias possibilidades. Uma possível contrapartida para isso é a expansão dos vínculos sociais dessa pessoa dentro do grupo. Um programador respeitado por suas contribuições ao sistema operacional Linux, por exemplo, se torna conhecido entre seus pares e aumenta sua rede de contatos.

Incentivo moral: O prazer associado à prática de boas ações estimula pessoas a doarem seu tempo e esforço. $\mathrm{Na}$ medida em que os custos de compartilhamento e distribuição forem próximos a zero, alguém que desenvolveu um programa para resolver um problema particular pode submeter seu trabalho para que outros se beneficiem dele."

Por isso, hoje as comunidades estão em plena expansão e muitas vezes não existem como uma proposta em si, mas são usadas como ferramentas para estabelecer diálogos com o público de determinado ambiente online e para reforçar sua ligação com o site. São parte de uma estrutura maior que tem outros objetivos além dos desenvolvidos pela Comunidade.

Independentemente do modelo utilizado, essas experiências podem (e costumam) oferecer espaços para as narrativas de histórias/vivências pessoais dos cidadãos que, até agora, eram apenas público dos veículos de comunicação e que 
passam agora a autores que lêem, são lidos, informam e são informados pelos seus pares.

O interesse que a temática que norteia a comunidade desperta é seu principal fator de audiência, que pode ser verificada pelo número de participantes e pelo efetivo grau de participação deles. No caso do Orkut, por exemplo, uma simples visita revela milhares de comunidades, muitas sobre os mesmos temas, e que apresentam número de participantes e graus de participação diferentes entre si.

Mas o maior fenômeno dos últimos anos chama-se blog. O formato consiste em armazenar posts ${ }^{127}$, com uma unidade temática ou não, que vão sendo dispostos na página, sempre com o mais recente disponível no alto da página. Além de, em geral, permitir que os leitores insiram comentários, o blog também permite o armazenamento dos posts e sua consulta pelo público.

Para ALONSO; MARTíNEZ (2003, p. 296) são cinco as características principais de um weblog:

"a) Es un espacio de comunicación personal. b) Sus contenidos abarcan cualquier tipología. c) Los contenidos presentan una marcada estructura cronológica. d) El sujeto que las elabora suele adjuntar enlaces a sitios web que tienen relación con los contenidos que se desarrollan. e) La interactividad aporta un alto valor añadido como elemento dinamizador en el proceso de comunicación."

É importante ressaltar que o formato não requer que o interessado em publicar conheça a linguagem de construção de páginas web, já que é disponível em forma de templates ${ }^{128}$. Com essa facilidade um número maior de autores pode participar da

127 Posts são atualizações (registros de informações, comentários etc) organizadas cronologicamente. Em geral, são textos, mas a variação fotográfica do blog (o fotolog) tem ganhado adeptos dia-a-dia.

128 Páginas web, sem conteúdo, utilizadas como modelos para o layout gráfico do weblog. Ou mais simplesmente, a descrição do weblog sem o "recheio". 
mídia, criando conteúdos diversificados. E é justamente esse conteúdo autoral que, segundo GILLMOR (2005, p. 47), leva o público a voltar a um blog:

"Porém o que convida as pessoas a voltar aos blogues pessoais é a perspectiva individualizada que eles oferecem."

No que se refere aos textos, ele reproduz, de maneira mais intensa, o formato reduzido adotado pela internet. A necessidade de publicar os posts com freqüência deu origem a um texto mais limpo e curto e, quando feito com qualidade, aproximase "mais da crônica, do ensaio ou de uma boa ficção" (SCHITTINE, 2004, p. 155).

Os primeiros blogs surgiram no meio da década de 90 . Entre os pioneiros estão os americanos Carolyn Burke, com o Carolyn Diary, criado em 1995 (e que não está mais no ar) e Justin Allyn Hall, que criou o Justin's Links from the Underground ${ }^{129} \mathrm{em}$ 1994 e ainda hoje no ar. Inicialmente podiam ser contados facilmente - hoje isso já não é mais possível. Os blogs multiplicamse dia-a-dia e seus autores não são mais apenas jovens adolescentes, disseminando-se entre todas as categorias de internautas.

No Brasil, a gaúcha Viviane Vaz de Menezes é considerada a primeira a criar um blog, o Delights to Cheer, escrito em inglês e lançado em fevereiro de 1998. Um mês depois (março de 1998), Renato Pedroso Júnior, o Nemo Nox, publica o primeiro blog em português, o Diário da Megalópole. O blog era praticamente um site porque não existiam ainda ferramentas para a criação automática e o autor precisava fazer tudo em HTML (LEAL, Fred, 2007). Nemo Nox continua em atividade até hoje. Seu

${ }^{129}$ www. links. net 
blog atual, Por um Punhado de Pixels ${ }^{130}$ (http://www.nemonox.com/ppp), está no ar desde janeiro de 2001. O autor, hoje vivendo nos Estados Unidos, narra seu dia-adia e comenta sobre música e cinema. Para ele, o blog "continua sendo pouco mais que meu livrinho de anotações, sem optimizações ou monetizações." (POR UM PUNHADO, 2007)

Entre os que permanecem no ar, é considerado o mais antigo, o "Zamorim"131, do brasiliense Marcus Amorim, que entrou no ar em março de 2000. (INAGAKI, 2007)

A questão dos temas também é igualmente variada: de histórias pessoais e blogs temáticos, não há limites para a criatividade dos autores.

"...os diários se configuram de maneira bastante distinta. Há aqueles que mantêm a prática manuscrita de relatar acontecimentos íntimos do cotidiano do autor, aqueles que se apresentam como uma versão 'comedida' destes mesmos relatos, intercalando informações de todo tipo com relatos íntimos, e aqueles diários que se apresentam como jornais pessoais, onde o autor comenta livros, discos e todo tipo de acontecimento." (CARVALHO, 2002, p. 8)

A pluralidade dos temas e autores é, para LEMOS (2002,

p. 2, grifos do autor), resultado das possibilidades geradas pela nova mídia:

"A emergência dessas páginas pessoais está associada a novas possibilidades que as tecnologias do ciberespaço trazem de liberação do pólo da emissão, diferentemente dos mass media que sempre controlaram as diversas modalidades comunicativas. Esta liberação do emissor (relativa, como toda liberdade, mas ampliada em relação aos mass media) cria o atual excesso de informação, mas também possibilita expressões livres, múltiplas. O excesso, paradoxalmente, permite a pluralização de vozes e, efetivamente, o contato social."

\footnotetext{
${ }^{130} \mathrm{http}: / /$ www.nemonox.com/ppp

${ }^{131}$ www.zamorim.com
} 
No entanto, é importante ressaltar que a maioria ainda tem a proposta de funcionar como um diário virtual, com as revelações e impressões do cotidiano que marcam esse tipo de publicação. E isso é resultado do exercício máximo da autoria permitida pela rede:

"Enquanto algumas publicizações midiáticas cujas estruturas implicam em coletividades de atuação podem prosseguir independentemente de ausências ou falta de iniciativas de parte de seus autores - a produção de um jornal, programa de televisão, revista científica pressupõem um coletivo - os diaristas online, por sua vez, 'tomam nas mãos' uma parte significativa do processo produtivo, e com isso, estabelecem uma relação de subjetivação com sua obra específica." (FISCHER, 2004, p. 3, grifos do autor)

Mas mesmo sendo o blog um espaço fundamentalmente individual, é cada vez mais comum a associação entre grupos deles. No Brasil, data de 2001 a criação do primeiro webring (uma espécie de ambiente virtual com catalogação e links para diversos blogs) de blogs nacionais, o Arredores (INAGAKI, 2007). A estratégia visa a divulgar os blogs inscritos e permutar as audiências entre eles:

"Até agora, os blogues têm sido um meio de comunicação usado principalmente a título individual, embora os blogues de grupos estejam a provar ser um meio adequado em determinadas circunstâncias. Os blogues individuais mais populares atraem milhares de visitantes por dia. Pode afirmar-se com segurança que vários milhões de pessoas já tiveram contacto com 0 processo." (GILLMOR, 2005, p. 47)

Os próprios portais e sites disponibilizam serviços de blogs, a fim de oferecer espaços para a participação de seu público e, ao mesmo tempo, captar mais conteúdo. Assim, se de um lado temos páginas (blogs) com audiência restrita individualmente, o site que os reúne tem a somatória dessas audiências, criando, inclusive, um resultado interessante comercialmente. 
No segmento dos sites especializados em blogs, o primeiro foi o Blogger ${ }^{132}$, criado por uma pequena empresa de San Francisco - EUA, em agosto de 1999. Em 2002, foi comprado pelo Google $e^{133}$.

No Brasil, o Weblogger ${ }^{134}$ surge em 2001. Em 2002 o serviço passou a pertencer ao Terra.

Entre os portais nacionais, o IG é o primeiro a aderir à onda, criando seu próprio serviço de hospedagem gratuita, o Blig ${ }^{135}$, em novembro de 2001. O Globo.com lança a versão brasileira do Blogger ${ }^{136}$ em 2002 e em 2004 fecha o serviço apenas para seus assinantes. O UOL é o último dos grandes portais nacionais a lançar seu serviço de blogs ${ }^{137}$, em janeiro de 2004. (INAGAKI, 2007)

O assunto blogs se torna tema para a grande mídia já em 2001, quando a Folha de S. Paulo publica a matéria "Weblogs reinventam o uso da Internet". Em 2003, o blog coletivo Virunduns $^{138}$ torna-se o primeiro blog a aparecer na capa dos cadernos de variedades do J ornal da Tarde e de O Globo (INAGAKI, 2007). Virunduns reúne depoimentos sobre os erros que as pessoas cometem ao cantar uma música. Seu próprio título é uma brincadeira com uma das formas de se cantar o início do Hino Nacional ("Ouviram do"). O site já teve diversas fases e ainda permanece no ar.

Mas além dessa categoria de blogs criados e mantidos pelo próprio público da internet, os veículos de comunicação têm

\footnotetext{
132 www.blogger.com

133 www.google.com. A mesma empresa dona do Orkut e um dos principais sites

de busca do mundo.

134 http://weblogger.terra.com.br/

135 http://blig.ig.com. br/

${ }^{136} \mathrm{http}: / /$ blogger.globo.com

${ }^{137} \mathrm{http}$ ://blog.uol.com.br/

138 http://www.interney. net/blogs/virunduns
} 
utilizado também o modelo para as informações produzidas pelos seus próprios profissionais. O espaço tradicionalmente destinado aos colunistas na mídia impressa, é recuperado na internet a partir dos blogs e hoje praticamente todos os portais oferecem colunas variadas (principalmente de política, esportes, economia e variedades). Essas publicações têm em comum com os blogs dos leitores o fato de serem produtos autorais, mas têm o diferencial de serem produzidos por profissionais e não pelo público comum que interessa a este trabalho.

O grande fenômeno entre os blogs confessionais no Brasil foi O diário de Bruna Surfistinha ${ }^{139}$, relatos de uma garota de programa sobre suas experiências com clientes e sua vida em geral. A união da temática intimidade com sexo fez o blog explodir em 2005 chegando a ter 15 mil visitantes por dia. A autora foi alavancada ao status de celebridade do momento. A fama obtida com o blog rendeu dois livros: "O doce veneno do Escorpião - o diário de uma garota de programa" (lançado também em Portugal e Espanha, atingiu 250 mil exemplares) e "O que aprendi com Bruna Surfistinha" (18 mil exemplares) e uma revista em quadrinhos erótica (MATTOS, 2007). O blog permanece no ar, com os pensamentos e novas experiências associados agora à propaganda das "atividades" dela na mídia: entrevistas que deu, sites que falam sobre ela e/ou sobre os livros etc., num formato muito semelhante ao dos blogs das celebridades.

Sobre os blogs de anônimos voltados à narrativa de seus cotidianos, é importante ressaltar o interesse que essas histórias despertam no público, independentemente do conteúdo apresentado:

139 http://www. brunasurfistinha.com/blogs/ 
"Do mesmo modo, na Internet, pessoas desconhecidas costumam acompanhar com fruição o relato minucioso de uma vida qualquer, com todas as suas peripécias registradas pelo próprio protagonista enquanto elas vão ocorrendo, dia após dia, de hora em hora, minuto a minuto, com o imediatismo do tempo real, por meio de torrentes de palavras que de maneira instantânea podem aparecer nas telas de todos os cantos do planeta - textos que, muitas vezes, são complementados com fotografias $e$, inclusive, com imagens de vídeo transmitidas ao vivo e sem interrupção. Desdobra-se, assim, nas telas interconectadas pelas redes digitais, todo o fascínio e toda a irrelevância de 'a vida como ela é'." (SIBILIA, 2003, p. 5-6, grifos da autora)

\section{O interesse faz parte da glamourização da vida}

cotidiana, fenômeno que não é exclusivo das mídias digitais:

"A vida comum transforma-se em algo espetacular, compartilhada por milhões de olhos potenciais. E não se trata de nenhum evento emocionante. Não há histórias, aventuras, enredos complexos ou desfechos maravilhosos. Na realidade, nada acontece, a não ser a vida banal, elevada ao estado de arte pura. A vida privada, revelada pelas webcams e diários pessoais, é transformada em um espetáculo para olhos curiosos, e este espetáculo é a vida vivida na sua banalidade radical. A máxima é: 'minha vida é como a sua, logo tranqüilize-se, estamos todos na banalidade do quotidiano'." (LEMOS, 2002, p. 12 , grifos do autor)

\section{Como já ressaltamos, o crescimento do espaço para a}

intimidade é detectável em todos os meios de comunicação:

"Analisando esse aparente paradoxo, percebe-se que o fenômeno da intimidade aberta ao público não é exclusivo dos diários íntimos. É freqüente e está no mundo atual de várias maneiras. A presença, cada vez maior, dos reality shows na televisão e das webcams, - sucesso das revistas de fofoca e a volta dos paparazzi mostram quanto interesse o público tem intimidade alheia. E, o que é mais importante, o quanto ele tem sede de uma intimidade que não é necessariamente protagonizada por gente famosa, mas por pessoas comuns parecidas, o quanto possível, com o próprio público." (SCHITTINE, 2004, p. 32) 
Do ponto de vista do autor, a temática da própria vida na internet traz a possibilidade de se relacionar com um público desconhecido, mas protegido pela tecnologia. Segundo SCHITTINE (2004, p. 14, grifos da autora):

"O motivo inicial é aquela necessidade de ser lido, da qual Lejeune já havia falado em vários estudos e, principalmente, no livro 'Cher écran...', onde começou a estudar um grupo de diaristas que escrevia o diário no computador e alguns entre eles que o colocavam em rede. A internet abre, para o diarista, a possibilidade de ser lido sem que, no entanto, ele precise desenvolver relações face a face com os seus leitores, um público formado por desconhecidos. Essa possibilidade é encorajadora para quem começa a escrever. O segundo motivo seria a existência de 'leitores desconhecidos' que, de acordo com os anseios do diarista, se interessam pelos seus assuntos pessoais. É um público novo, interessado em consumir a intimidade alheia e, de certa forma, em descobrir o quanto ela se aproxima da sua própria intimidade."

O estabelecimento desse diálogo é assim descrito pela autora (SCHITTINE, 2004, p. 21):

"É pelas mãos desse novo tipo de confidente que se perpetuam muitos dos acontecimentos da vida privada do diarista. É esse Outro que, junto com o autor, vai ajudar a tecer a trama de que é feita a memória do blogueiro. Pela primeira vez o Outro é chamado também a participar e a perpetuar 0 conteúdo do escrito íntimo, o que faz com que a memória pessoal seja construída de maneira menos alienante, não só pelo monólogo do autor, mas pela contribuição alheia. E por que a necessidade da ajuda desse Outro? Porque o autor conta com a lembrança do Outro para propagar a memória de si mesmo."

São os blogs também que mais inovam, entre os produtos comunicacionais, na questão da mediação. É a primeira vez que uma comunicação feita pelo público não é submetida a nenhum tipo de mediação humana fora o próprio autor. Ele tem pleno domínio sobre a mensagem que está divulgando e suas únicas limitações são quanto à forma e espaços determinados pelo 
template adotado - uma mediação tecnológica. Esse autor tem ainda controle sobre a participação dos demais leitores, podendo editar, recusar ou apagar contribuições e/ou comentários.

Já nas comunidades virtuais, a extensão da mediação humana é variável de acordo com o modelo e regras adotadas em cada uma. Em comum entre elas está a mudança do perfil do profissional que administra mensagens, tópicos, participações. De uma função de editoração e autoria que marca os meios de comunicação impressos e eletrônicos, teremos uma função de moderação na mídia digital. Mesmo quando a mediação é feita pelo coletivo de participantes, não há o controle absoluto pelo autor acerca de sua participação - ela é submetida à avaliação dos demais colaboradores. Já a questão da mediação tecnológica permanece, com a adaptação da participação aos espaços e formas pré-determinados e administrados pelo computador. 
IV. ESTUDOS DE CASO

“Toda história de vida tem valor e deve fazer parte da memória social." (Museu da Pessoa) 


\section{Eu, Leitora - Revista Marie Claire}

A revista Marie Claire é uma publicação feminina da Editora Globo que completou 16 anos de Brasil em abril de 2007. Segundo dados do IVC é a 20 ạ publicação em circulação nacional. Seu slogan é "Chique é ser inteligente".

Traz a seção "Eu, Leitora" desde o seu primeiro número, em 1991. Segundo Fernanda Cirenza, editora da coluna, o espaço é uma marca da revista:

"A idéia de texto 'aspeado', para usar um jargão jornalístico, para narrar uma história sob o ponto de vista do protagonista (ou seja, daquele que viveu ou vive a história) é uma marca de Marie Claire - não só a brasileira, como as edições estrangeiras." 140

A temática da seção é livre e os relatos são propostos pelas próprias leitoras (segundo a editora, há também participação de leitores). Não há dados sobre o número de contribuições que a revista recebe mensalmente.

Depois as histórias passam por uma seleção editorial. O critério, segundo a editora, é o interesse que a história possa despertar:

"Evidentemente, que a revista seleciona os casos. Quer dizer, a história precisa realmente interessar à revista. Alguns quesitos precisam ser considerados, ou seja, não basta ter uma história para contar. Essa história precisa representar algo: trazer uma informação, ser edificante, emocionar e, às vezes, chocar." (...) "A história precisa ter um apelo, seja ele qual for. Então, pode ser um tema chocante (ex: o dia em que transei com dois irmãos ao mesmo tempo),

\footnotetext{
${ }^{140}$ Entrevista concedida por e-mail, disponível no Anexo 2. O cabeçalho deste e de todos os demais e-mails colocados nos Anexos tiveram as informações pessoais suprimidas a fim de proteger os dados pessoais dos entrevistados.
} 
amor com todos os ingredientes (amor, é claro, doença e morte), informação (a história da moça que foi submetida a uma cirurgia com célula-tronco e teve sua vida mudada para melhor - essa história fez sucesso, muitos leitores nos procuraram pedindo os contatos dos médicos que dominam a técnica), edificante (a história de uma mulher que adotou uma criança soropositiva)... Raramente o apelo é a temperatura da notícia, mas às vezes isso acontece, como foi no caso do tsunami (entrevistamos uma sobrevivente brasileira). O fato é que essa seção está preocupada em ouvir a versão daquela pessoa que tem uma história interessante para contar, seja ela qual for.“

Uma vez por ano, a revista promove um concurso para histórias sobre uma temática determinada pela publicação. As contribuições são selecionadas por um júri e são eleitas três histórias cujas autoras recebem um prêmio.

Os depoimentos não são publicados integralmente. Se a história interessa à revista, o autor é entrevistado por um repórter ou editor que produz o texto publicado. Em cada seção, consta “Depoimento a" e o nome do jornalista que colheu o depoimento. Segundo Fernanda, reescrever o depoimento é necessário porque os textos recebidos não vêm em formato pronto para a publicação. As alterações não são apenas de forma - na entrevista, o repórter levanta outras informações que não estavam no relato inicial e as inclui no texto final:

"Os textos que recebemos são textos, às vezes muito bem escritos, mas fora de uma ordem lógica para a publicação. Em geral também, as pessoas que escrevem deixam 'buracos' nos textos que elas vivenciaram - isso é muito comum. Você conhece tanto aquela história que deixa de informar um monte de coisas, imaginando que quem está lendo também conhece aquela história. Existem também as questões técnicas: textos muito resumidos ou longos demais... Então, o caminho é esse: o autor é entrevistado, o texto é escrito por um repórter e depois, se necessário, editado pelo editor." 
A Revista não arquiva todos os depoimentos enviados, mas as informações puderam ser comprovadas por alguns relatos encaminhados. Disponibilizamos no Anexo 3 um relato que originou uma das matérias analisadas (matéria 2).

\section{a. Edições analisadas}

1) "Tive meu primeiro orgasmo aos 40 anos" - leitora Lúcia (nome trocado a pedido da leitora), arquiteta, 43 anos. Não consta a quem foi dado o depoimento - revista no 196, Julho de 2007, p. 99-102.

2) "Uma cirurgia com célula-tronco mudou minha vida" - leitora Giulia Costa, pedagoga, 38 anos. Depoimento a Marina Morena Costa (Colaborou: Fernanda Cirenza) - revista no 197, Agosto de 2007, p. 89-92.

3) "Só aprendi a ser mãe depois de virar avó, aos 44 anos" leitora Laura (nome trocado a pedido da leitora), advogada, 56 anos. Depoimento a Bia Mendes - revista no 198, Setembro de 2007, p. 115-18.

4) "Acreditei na intuição, tive sorte e realizei o meu sonho: conhecer Paris" - leitora Mariza Marques, psicóloga, 48 anos. Depoimento a Janette Bacal - revista no 199, Outubro de 2007, p. 119-22.

5) "O dia em que meu marido morreu na frente dos nossos filhos" - leitora Ana Cecília Romano Cury, empresária de moda, idade não informada. Depoimento a Fernanda Cirenza - revista no 200, Novembro de 2007, p. 161-4. 
O tamanho da Seção "Eu, Leitora" é padronizado em todas as edições: quatro páginas. Trata-se de um espaço grande dentro da organização da Revista, cujas maiores matérias não ultrapassam oito páginas (com exceção dos editorais de moda que chegam até a mais de 20 páginas).

O espaço é significativo, principalmente, se levarmos em conta que a seção "Eu, Leitora" não traz, praticamente, nenhuma ilustração, enquanto as matérias em geral de Marie Claire são bastante ilustradas chegando, em algumas delas, a se trabalhar com a proporção de $50 \%$ de texto e $50 \%$ de ilustrações.

Nas quatro páginas de "Eu, Leitora" há apenas um anúncio no centro de sua terceira página acompanhada de uma faixa na parte inferior da mesma página (do mesmo anunciante). Os dois espaços correspondem a cerca de $35 \%$ de uma página.

A publicidade é do mesmo anunciante que ocupa também a página que antecede à matéria (a seção "Eu, Leitora" sempre começa numa página ímpar), sugerindo que trata-se de um patrocínio. O anunciante foi o mesmo nas cinco edições analisadas.

Sem nenhuma ilustração, o olho ${ }^{141}$ é o principal recurso gráfico adotado na seção a fim de formatá-la dentro do padrão da Revista. O mesmo recurso é usado em variadas matérias e, principalmente, em outras seções fixas da publicação.

Em "Eu, Leitora", a diagramação obedece a um esquema fixo em que cada página (com exceção daquela com publicidade) traz um olho, sempre com algumas palavras em negrito e em corpo maior que as demais. Na primeira página da matéria, o título do depoimento é deslocado para o meio da página

\footnotetext{
${ }^{141}$ Intertítulo ou pequeno trecho em destaque introduzindo o tema ou chamando a atenção para algum trecho da matéria.
} 
e traz algumas palavras em outra cor (o vermelho). Há também a utilização de capitulares em alguns parágrafos, que se destacam do texto.

Reproduzimos abaixo os olhos de cada uma das matérias analisadas, respeitando os negritos e tamanhos diferenciados com as respectivas páginas em que aparecem:

1) p.99: "TIVE MEU PRI MEI RO ORGASMO AOS 40 ANOS"; p.100: "SONHAVA SEMPRE COM UM MESMO HOMEM. ELE ME SEDUZIA E ME FAZIA FELIZ. MAS NADA DE EU TER O TÃO DESEJADO PRAZER"; p. 102: “EU TIVE O MEU PRIMEIRO ORGASMO SOZINHA, DURANTE O BANHO. E, SE NÃO FOSSEM OS ACESSÓRIOS ERÓTICOS, O MEU CASAMENTO ESTARIA ARRUI NADO"

2) p. 89: “UMA CIRURGIA COM CÉLULA-TRONCO MUDOU MI NHA VI DA"; p. 90: "NUNCA SENTI PENA DE MIM. APRENDI COM A MINHA FAMÍLIA A NÃO FAZER DRAMA DIANTE DE UMA CRISE"; p. 92: “JÁ USEI SANDÁLIA RASTEIRA E BOTA DE CANO LONGO. AGORA ME PREPARO PARA O PRIMEIRO SAPATO DE SALTO ALTO DEPOIS DE 17 ANOS"

3) p. 115: “SÓ APRENDI A SER MÃE DEPOIS DE VIRAR AVÓ AOS 44 ANOS"; p. 116: "SEMPRE AMEI OS MEUS FILHOS. MAS QUERIA CURTIR O MELHOR DA VIDA, E ELES ACABARAM FICANDO DE LADO"; p. 118: "COM MINHAS NETAS FAÇO COISAS QUE NUNCA FIZ COM OS FILHOS. ASSIM, EU REVEJO MEU PASSADO E CURO AS MI NHAS FERI DAS"

4) p. 119: “ACREDITEI NA I NTUIÇÃO, TIVE SORTE E REALIZEI O MEU SONHO: CONHECER PARIS"; p.120: “QUANDO A TORRE EIFFEL SE ILUMINOU, À MEIA-NOITE EM 
PONTO, EU FIQUEI PARALISADA, COM OS OLHOS CHEIOS DE LÁGRI MAS"; p. 122: "AGORA, MAIS DO QUE NUNCA, EU TENHO CERTEZA DE QUE UMA MENTE POSITIVA É CAPAZ DE ATRAIR COISAS BOAS"

5) p. 161: “O DIA EM QUE MEU MARIDO MORREU NA FRENTE DOS NOSSOS FILHOS"; p. 162: “NO ÚLTIMO REVEILLON, CHICO PARECIA CONTENTE. EU ACHO QUE ESSE FOI O ÚlTIMO DIA MAIS FELIZ DE NOSSAS VIDAS"; p. 164: “DEPOIS DE DEZ MESES DA MORTE, SENTI CHICO DO MEU LADO. ELE ME DIZIA QUE EU NÃO DEVIA SOFRER, QUE PRECISAVA CONTI NUAR A VI DA"

A seção recebe destaque da revista no Sumário e, às vezes, também na Capa. Das cinco edições analisadas, duas tiveram chamada na capa (edições de julho e de novembro). Todas tiveram destaque no Sumário que é dividido nas retrancas: "Na Capa", “Reportagem", “Moda", "Beleza" e "Sempre Aqui". Com exceção da seção das edições de julho e novembro (que, como receberam chamada na capa da revista, aparecem no sumário na retranca "Na Capa"), todas as outras aparecem em "Reportagem".

A classificação mostra que a revista considera a seção um espaço jornalístico e, como tal, diferenciado das outras seções que integram a revista permanentemente e que são indicados na retranca "Sempre Aqui". Estão neste grupo, a seção de cartas, colunistas (Adriano Silva - "Carta para Você", Patrícia Travassos “Mil Coisas" e Leila Ferreira - “Nós, Mulheres") e notícias de lançamentos (Top 10) em Cultura, Moda e Beleza.

A interpretação da seção como um espaço jornalístico é também explícita no chapéu usado na seção: “Marie Claire Vida Real". Ambos (a classificação no Sumário e o chapéu usado para 
seção) confirmam os procedimentos informados na entrevista (seleção do caso, entrevista e redação feitas por um jornalista da equipe).

Comparativamente com as outras matérias de seu grupo ("Reportagem"), a seção "Eu, Leitora” cresce ainda mais de importância. Em julho, a parte de "Reportagem" trazia quatro matérias, a maior delas "Filhas da Esperança", com sete páginas e meia, sendo que quatro destinadas a fotografias e três páginas e meia para texto. As outras três traziam duas páginas e meia, aproximadamente, de texto ("O que você salvaria num incêndio?" quatro páginas e meia no total; "I sabela Garcia" - quatro páginas; e "Nos embalos da Neve" - cinco páginas). Em agosto, além de "Eu, Leitora", são outras duas reportagens: "O jeito moderno de ser simples" (três páginas e meia de texto em um total de cinco páginas e meia) e "Milão fora do lugar comum" (duas páginas e meia de texto em um total de seis páginas e meia). Em setembro, duas reportagens dividiam com "Eu, Leitora" a chamada no sumário, uma com três páginas e meia de texto ("Mulher é amiga de mulher, sim!" - quatro páginas e meia) e outra com duas páginas e meia ("Vôo livre" - cinco páginas). Outubro trouxe em "Reportagem", o ensaio "Retratos da Sensualidade" (três páginas de texto de um total de dez); "Pequeno manual de Bruxaria" (quatro páginas e meia de um total de sete); e "Índia - minha primeira vez" (quatro de um total de seis páginas). Em novembro, foram cinco matérias: "Circuncisão feminina" (três páginas e meia de texto de um total de sete); "Jovens de A a Z" (três de seis); "Diário Desplugado" (três de seis); “Pesquisa Marie Claire" ( quatro páginas e meia de um total de seis páginas e meia); e "Vitória da Tolerância" (três de cinco). 
Assim, a seção "Eu, Leitora", com suas quase quatro páginas de texto é das maiores matérias dentro do espaço de reportagem.

No que se refere aos temas tratados, a seção não trabalha com uma linha comum, adotando a variedade temática. Tampouco o tom da narrativa é o mesmo, indo de histórias dramáticas até relatos mais leves. São vivências do cotidiano humano. No entanto, as histórias têm em comum serem relatos de conquista de um sonho ou superação de uma dificuldade.

Entre as edições analisadas, não tivemos nenhuma vez a repetição de uma temática: temos um relato sobre sexualidade ("Tive meu primeiro orgasmo aos 40 anos" - edição de julho); um sobre saúde ("Uma cirurgia com célula-tronco mudou minha vida" agosto); um sobre comportamento ("Só aprendi a ser mãe depois de virar avó, aos 44 anos" - setembro); um sobre viagem ("Acreditei na intuição, tive sorte e realizei o meu sonho: conhecer Paris" - outubro); e um sobre a perda de um ente querido ("O dia em que meu marido morreu na frente dos nossos filhos" novembro).

Essas temáticas estão de acordo com os critérios adotados para as pautas em geral da revista já que aparecem em outras matérias e edições. Sexualidade é tema de "Sexo na cabeça: será que eles só pensam (mesmo) nisso?", da edição de outubro, por exemplo; saúde é tema das matérias "Alerta: 'Peguei o vírus da AIDS na balada'", da edição de outubro; comportamento aparece em "Novas solteiras - elas contam como é voltar a ser livre depois de um longo relacionamento" - de julho ou "Mulher é amiga de mulher, sim!" - de setembro; e viagem está presente em todas as edições. 
Em comum a todas elas, o final feliz, com a superação de um obstáculo ou a realização de um sonho, como pode ser visto na transcrição do último parágrafo de cada matéria:

1) "Chegar ao clímax, ainda que sozinha, e a descoberta dos acessórios salvaram o meu casamento. Hoje, Pedro e eu temos relações gostosas, sempre com a ajuda dos brinquedinhos. Também aprendi a me masturbar e sou feliz assim - não passo uma semana sem me valer do vibrador. Em tanto tempo juntos, posso dizer que não tenho uma grande atração física por ele, mas Pedro é o homem que eu admiro e com quem eu quero estar. Tenho certeza de que ele também me ama. Passar o que ele passou comigo não é para qualquer homem."

2) 'Ainda estou me adaptando 'ao meu novo corpo'. Às vezes me pego andando descalça na ponta do pé, como fazia antes, quando a diferença das pernas era maior. Mas comecei a fazer aulas de consciência corporal para reaprender os meus movimentos, o meu corpo e o espaço que ele ocupa. Meus sonhos continuam. Quero voltar a trabalhar com educação e, de alguma forma, ajudar as pessoas. E, daqui para a frente, espero não ver mais nenhum Carnaval pela TV. No ano que vem quero sair atrás do trio elétrico de novo. Tenho certeza de que vou conseguir."

3) “Pedro também mudou, é um ótimo pai e um avô carinhoso. O que acho mais bonito dessa história é que posso recontá-la de um jeito novo por meio das minhas netas. Com elas, revejo meu passado, curo minhas feridas e escrevo um futuro ao lado dos meus filhos."

4) "Por mais de um ano, vivemos em meio a tijolos, cimento, areia. No final, construímos uma casa linda, com piscina e seis quartos. Monique e Baltazar já nos visitaram. Voltaram ao Brasil em janeiro do ano passado, ficaram 15 dias com a gente. Agora sonho com 
outros destinos. Roma, Londres, Praga, Madri e (por que não?) Paris de novo. Quem sabe não passo um ano inteiro rodando pelo mundo? O sonho de Luiz Carlos de construir a casa está realizado. O meu, acho, não vai ter fim nunca."

5) "À noite, fui para a casa de amigos passar o reveillon e encontrei um outro amigo em comum, separado. Batemos papo, dançamos, mais nada. Um mês depois, ele me convidou para um passeio que incluía as crianças. Esse gesto me conquistou. Ele é muito companheiro e sensível a tudo que passei. Faz sete meses que estamos saindo, é um romance bem suave. Gosto do meu atual namorado, mas Chico nunca mais vai sair da minha cabeça. O amor que sinto por ele jamais será substituído, mas a vida segue em frente e, se possível, com alegria."

Todos os relatos são feitos em primeira pessoa, como se a própria leitora estivesse contando sua história (embora, como vimos na entrevista com a editora Fernanda Cirenza, o texto final é preparado por um jornalista e/ou editor). Apenas o resumo inicial do caso está na "voz" da revista. Os casos analisados foram assim apresentados:

1) “Casada, mãe de dois filhos e arquiteta bem-sucedida, Lúcia* parecia levar uma vida feliz. Na intimidade, porém, um fantasma a atormentava: não conseguia chegar ao orgasmo com o homem que amava. Sem coragem de se entregar a outro parceiro e inconformada com a sua situação, Lúcia procurou ajuda com amigas e especialistas e teve que percorrer um longo caminho até chegar ao tão desejado prazer. Aqui, ela conta com detalhes como foi essa descoberta que a levou à superação dos próprios limites e, de quebra, esquentou o seu casamento.

*O nome foi trocado a pedido da leitora." 
2) "Giulia Costa tinha 20 anos e o sonho de se formar pedagoga quando foi atropelada por um carro em alta velocidade. O resultado do acidente foi uma fratura na perna esquerda que a deixou deficiente física. Depois de 14 cirurgias e 15 anos vivendo com limitações, Giulia aceitou ser a primeira paciente do mundo a se submeter à técnica cirúrgica que combina osso sintético e células-tronco. Recuperada, ela conta como está 'reaprendendo a viver'. Depoimento a Marina Morena Costa (colaborou: Fernanda Cirenza)"

3) "A advogada Laura* se casou aos 16 anos, saltando da adolescência para o mundo dos adultos por vontade própria. Logo se tornou mãe, mas a maternidade não atrapalhou seus planos de se tornar independente. Levou tão a sério a idéia que acabou se distanciando física e emocionalmente dos filhos. Mais tarde foi obrigada a administrar as conseqüências desse 'abandono'. Hoje, aos 56 anos, ela faz um balanço daquela época e afirma: 'Faria tudo diferente'. Agora, Laura tenta reparar as ausências do passado a partir da convivência com suas netas. Depoimento a Bia Mendes.

* Os nomes foram trocados a pedido da leitora."

4) "Mariza Marques, psicóloga de 48 anos, sempre quis viajar pelo mundo, a começar por Paris. Casou, teve três filhos e se viu diante de uma série de compromissos que a impediam de realizar seu sonho. Uma hora, cansada de levar uma vida sem surpresas, acreditou na intuição e decidiu mudar a ordem de suas prioridades. o marido ficou cismado, mas embarcou na dela. Uma série de coincidências começou a aparecer, ajudando Mariza a perceber que Paris não era tão longe assim. Depoimento a Janette Bacal."

5) "A empresária de moda Ana Cecília Romano Cury dirigiu cem quilômetros em uma estrada, na tentativa de levar seu marido 
doente ao hospital. No banco de trás, os gêmeos Laura e André, de 5 anos na época, obviamente não entendiam a gravidade da situação. Nem ela, apesar de sua aflição. Felizmente, as crianças dormiam quando Ana Cecília percebeu que seu marido já não respirava mais. Em estado de choque, mas com uma lucidez que nem ela sabe explicar, continuou dirigindo e voltou para casa, com o marido morto. Depoimento a Fernanda Cirenza."

As narrativas são construídas com frases curtas e vocabulário acessível. Os textos seguem a ordem cronológica dos fatos, desde o início da situação até a solução do conflito e/ou superação do obstáculo. O último parágrafo traz o resumo da vivência relatada, com as lições aprendidas pelo autor/personagem.

Praticamente não há a reprodução de diálogos. Quando eles aparecem, estão, em geral, na voz do autor. As poucas aspas utilizadas reproduzem apenas uma parte do que seria o diálogo com o restante narrado de forma indireta, como neste trecho da edição de outubro: "Cheguei em casa afobada, fiz todas as contas e pensei: 'Não tem como Luis Carlos me negar essa viagem'. À noite, na hora do jantar, disse a ele que tinha visto as passagens para Paris, os preços, as contas... Meio ressabiado, não disse sim nem não."

Das edições analisadas, a de outubro foi a que mais fez utilização desse recurso, com dez inserções, enquanto a de julho fez uso apenas uma vez de um diálogo (ainda que parcial) na ordem direta: "Ao desabafar com uma amiga, ela disse: 'Não se preocupe. Mãe é mãe'. Acreditei e, com extrema paciência, consegui fazer com que Sofia voltasse a me reconhecer."

\section{b. Conclusões}


O espaço dedicado ao relato das histórias pessoais do próprio público pela revista Marie Claire na seção "Eu, Leitora" é significativo quer pelo espaço ocupado (quatro páginas), quer pelo destaque que recebe na Capa e/ou Sumário.

A seção é considerada um espaço jornalístico (mais especificamente, de reportagem), fazendo com que os relatos sofram a mediação de jornalistas da revista tanto na seleção de quais casos publicar quanto na escolha da linguagem para a narrativa. Os textos são de autoria dos jornalistas/editores que entrevistam os leitores que desejam divulgar suas histórias.

Os relatos sofrem também as adequações pertinentes ao meio: adoção de elementos gráficos e enquadramento no tamanho destinado à seção. As adequações são realizadas pelos profissionais da publicação.

A seleção dos casos obedece aos critérios de noticiabilidade adotados pela revista em geral, assim como obedece às temáticas exploradas nas demais seções e espaços. 


\section{Revista Sou + Eu!}

A revista Sou + Eu! completa seu primeiro ano de existência no final de novembro de 2007. Sua proposta foi baseada no modelo inglês de revistas populares interativas como Chat, Take a Break, Pick me Up e Love It (SOU + EU!, 2006, p.3).

A revista é assim apresentada:

“- é a primeira revista da América Latina que aposta no segmento Vida Real leitores

- é a primeira revista feita totalmente pelos

- é a primeira que paga pelas histórias publicadas

- é a primeira a oferecer uma promoção que dá cinco prêmios de $\mathrm{R} \$ 1000$ em dinheiro pro semana (com aprovação pela Caixa Econômica Federal)" (SOU + EU!, 2006, p.1)

A remuneração é calculada de acordo com a contribuição enviada e varia de $R \$ 50,00$ a $R \$ 500,00$. O foco principal da revista são as histórias pessoais contadas pelo público anônimo, mas a publicação traz ainda dicas, piadas, receitas e até dúvidas enviadas pelos leitores.

Segundo Flávia Martinelli, editora, a revista recebe cerca de 5 mil contribuições por semana ${ }^{142}$, a grande maioria por internet. Para receber as contribuições e dar respostas sobre o andamento da sugestão, a editora montou um Serviço de Atendimento ao Leitor diferente, que funciona como uma grande base de dados.

"Todos os repórteres têm acesso a uma base de dados. Você manda sua historinha, sua receita, o que for pelo site e vai cair numa grande base de dados e lá fica tudo classificado por seção. Para participar, a

\footnotetext{
142 Entrevista concedida à autora desta Tese. Transcrição disponível no Anexo 4.
} 
pessoa tem que preencher um cadastro no Passaporte Abril, com nome, endereço, telefone, CIC, RG, tudo isso. Isso já inibe muito a que as pessoas inventem coisas ou queiram brincar. A pessoa tem que aceitar um Código de Ética e quando ela posta a sua história ela abre mão de seus direitos autorais, ela já é informada que o conteúdo será checado por uma equipe, que pode ser editado, enfim..."

As contribuições são lidas pelos repórteres que podem recusá-las ou levá-las para a reunião de pauta como sugestão. Se na reunião a pauta for aprovada, inicia-se o processo de checagem e a coleta das informações. Em cada estágio, o leitor/autor recebe uma mensagem informando sobre o andamento de sua sugestão.

Quando a contribuição chega por carta, é digitada no sistema e o leitor também passa a receber correspondências informando sobre as etapas e encaminhamentos.

Caso a matéria seja recusada em qualquer das etapas, o autor é automaticamente informado da recusa. Se for publicada, o sistema gera uma lista que emite vales postais para os autores que podem assim retirar seu pagamento numa agência dos Correios.

As fotos são em parte produzidas pela revista e, quando possível, são publicadas também fotografias do acervo pessoal do leitor. Os textos publicados não são os originalmente enviados pelos leitores ${ }^{143}$. Segundo Flávia Martinelli, às vezes, as histórias encaminhadas não têm mais que 10 linhas e outras vezes são narrativas longas em que o que realmente importa está perdido no meio do texto:

"Por exemplo, teve uma leitora que mandou uma história longa: eu nasci, eu cresci, meu pai, minha mãe, minha vida foi dura, etc etc etc. Aí eu lutei, eu vim prá São Paulo e aí eu fui estudar, terminei o colegial, consegui um emprego num consultório dentário. Lá no consultório dentário, eu recebia as

\footnotetext{
${ }^{143}$ Disponibilizamos no Anexo 5 um dos textos enviados por leitores e que resultou em uma das matérias analisadas.
} 
cartas e me apaixonei pelo carteiro e mandava cartas para mim mesma. Era uma linha e era a matéria. É o olhar do repórter, o olhar da redação sobre o que existe de novidade no material que a gente coleta."

Para construir o texto final, a Sou + Eu! tenta reproduzir a forma de falar dos entrevistados, inclusive incorporando regionalismos, como explica Flávia:

“Nós respeitamos a variação lingüística; todo repórter é orientado a respeitar. Uma empregada doméstica falando, ele tem o direito de falar como empregada doméstica. Nós não reproduzimos erros de português, mas se tiver lá uma palavra que fuja do vocabulário, do léxico daquela pessoa, eu edito na hora: opa! Quem é que está escrevendo? É a repórter ou é a Maria das Dores? Na revista a gente usa inclusive variações lingüísticas regionais: tchê, oxente, trem... A gente usa "prá", uma porção de coisas que depois volta do departamento de revisão da editora apontada como erros e a gente não liga."

A revista procura trabalhar com temáticas variadas embora alguns temas sejam freqüentes como histórias de amor e de superação. O critério comum é que elas sempre devem ter um desfecho positivo, devem ser histórias edificantes.

\section{a. Matérias analisadas}

1) "A verdade sobre a vida fácil" - leitora Priscila Ferreira, 23 anos, professora, São Paulo, SP - Reportagem: Daniela Zerbini - Revista no 45 - De 27/9 a 3/10 de 2007, p. 14-5. Recebeu R\$ 300,00.

2) "Perdi 57 kg por causa de uma blusa" - leitora Fabiana de Abreu, 24 anos, professora, Rio de Janeiro, RJ - Reportagem: Isabel Baeta - Revista no 46 - de 4/10 a 10/10 de 2007, p.26-7. Recebeu R\$300,00.

3) "Larguei o emprego para transar todo dia" - leitora Priscilla Grassi, 30 anos, comissária de bordo, São Paulo, SP - 
Reportagem: Juliana Vilas e Daniele Zerbini - Revista no 48 - de 18/10 de 2007, p. 38-9. Recebeu R\$300,00.

4) "De desempregado a dono de três bancas" - leitor Antônio Henrique Fernandes, 34 anos, empresário, Cariacica, ES Reportagem: Daniela Torres - Revista no 49 - de 25/10/07, p. 25. Recebeu R\$200,00.

5) "Meu namorado me traiu comigo mesma" - leitora Valquiria Paula dos Santos de Oliveira, 25 anos, funcionária pública, Volta Redonda, RJ - Reportagem: Daniele Zerbini - Revista no 50 - de 1이이, p. 26-7. Recebeu R\$300,00.

Optamos por descartar de nossa amostragem a revista no 47, de $11 / 10$ a 17/10 de 2007 porque era um especial sobre dietas, contrariando a variedade temática que caracteriza a revista. Embora Dieta seja um tema fixo da Sou + Eu!, nesta edição, 17 leitoras publicaram suas dietas e cada uma ganhou 100 reais.

Todas as matérias selecionadas tiveram chamada na capa e destaque no Sumário. Com exceção da matéria “De desempregado a dono de três bancas", da revista no 49 (uma página), todas as demais tem duas páginas.

Pelo padrão da revista, é o segundo maior espaço ocupado pelas matérias que não ultrapassam três páginas no total.

Há alguns elementos de padronização gráfica entre as matérias. Por exemplo, todas apresentam um olho com o resumo da história abaixo do título. São estruturas curtas com, em geral uma ou duas frases, como podemos observar na transcrição, além de vários intertítulos distribuídos pela matéria (esses elementos são grafados com fontes em outra cor):

1) "Já fui como a Bebel e aprendi, a duras penas, do que os homens gostam"; “A vida fácil é difícil”; e "Saí da 'vida' por amor" 
2) "Decidi emagrecer uns quilinhos para usar a peça numa festa e daí não parei mais"; "Compra com antecedência"; "Acharam que eu fiz redução do estômago!", "Depois da ginástica arrumei um namorado"

3) "Era comissária de bordo e não gostava de ficar dias sem sexo. Não há dinheiro que pague meu prazer"; "Não suporto três dias sem sexo!", “Já fizemos suingue"; "Será que sou tarada demais?"

4) “Em 2000 fui despedido. Transformei $R \$ 700$ em um patrimônio de quase R\$ 100 mil"; "Estava disposto a lutar"; "Nada nos detinha"; "Fiquei rico e famoso na região"

5) "Criei uma personagem fictícia na internet e descobri que ele era infiel"; "O Anderson atirava pra todo lado"; "Ele marcou encontro com a Paula!"; "Peguei-o no pulo!"

Outro elemento bem comum são as legendas das fotos impressas entre aspas e como se tivessem sido escritas à mão. A única exceção, na amostra analisada foi a reportagem "A verdade sobre a vida fácil", da edição no 45 . Nas demais temos:

2) "Magra, passei a ser elogiada por inteiro e ainda arrumei meu primeiro namorado"; "Ninguém olhava pra mim quando eu era gorda. No máximo, as pessoas elogiavam a minha altura: 1,85 metro"

3) "Chegamos a brigar algumas vezes porque ele estava cansado e não queria transar e eu ficava de cara feia. Hoje respeito"; "Como quem não dá assistência abre concorrência, tenho que dar conta do recado"

4) "Meu plano é chegar a dono de dez bancas. Já tenho três e no que vem vou abrir uma revistaria"

5) "O Anderson teve o que mereceu. Agora vai pensar duas vezes antes de enganar alguém pela Internet" 
Nas matérias com mais de uma página, é freqüente a utilização de boxes ${ }^{144}$ - às vezes mais de um na mesma matéria. Na matéria "A verdade sobre a vida fácil" - edição $\mathrm{n}$ o 45, por exemplo, são dois: um intitulado "Novela X Vida real" em que mostra as diferenças da realidade de Bebel (prostituta personagem de novela) e das prostitutas reais; o outro "Por debaixo dos lençóis" traz dicas da leitora para agradar aos homens. Nas matérias de dieta ("Perdi $57 \mathrm{~kg}$ por causa de uma blusa" - revista no 46, por exemplo), o recurso é utilizado para divulgar o cardápio adotado.

O box pode ser utilizado também para apresentar a comprovação da história narrada. Em "Meu namorado me traiu comigo mesma" - edição no 50 , há um com os scraps ${ }^{145}$ encontrados na página pessoal do namorado no Orkut e outro com a reprodução da primeira conversa entre os dois pelo Messenger do MSN.

Já em "Larguei o emprego para transar todo dia" - da revista no 48, o box é usado para inserir o depoimento do marido da leitora, confirmando a história.

As informações dadas pelos leitores, em particular as relacionadas a dietas são comentadas por especialistas. Assim, no quadro onde está o cardápio, pequenos comentários de nutricionistas mostram pontos falhos e dão sugestões para corrigir o problema. As matérias de dieta têm também, como padrão, apresentar fotos do antes e do depois. A diferença entre a qualidade das fotos produzidas pela revista e das do acervo pessoal do leitor são visíveis e acabam acrescentando um elemento a mais de comprovação da veracidade da história.

\footnotetext{
${ }^{144}$ Box ou Quadro é um espaço graficamente delimitado que traz informações específicas relativas à matéria principal.

${ }^{145}$ Recados deixados numa página que se assemelha a um mural.
} 
Na matéria principal (fora os boxes e fotos), em geral o texto não ultrapassa uma página.

Como os textos publicados são sempre em primeira pessoa, não há aspas nas matérias, a não ser quando se reproduz um diálogo ou trecho dele. As matérias têm o tom de um relato informal, e são iniciadas mostrando o assunto central e procurando prender o leitor. Reproduzimos o primeiro parágrafo de cada matéria:

1) "Me casei com o Paulo* aos 19 anos. Ele era piloto e foi transferido pra outro Estado. Vinha pouco pra casa e, certo dia, recebi uma ordem de despejo. Paulo não pagava os aluguéis. Entrei em desespero e liguei pra ele. Sabe o que ele me disse? "Se vira! Se você for despejada, volta pra casa dos seus pais." Lembrei-me na hora do outdoor que tinha visto dias antes pela janela do ônibus quando saí para procurar emprego. Era o anúncio do café Millenium, uma casa de prostituição. Decidi ir até lá tentar a sorte.

* Os nomes foram trocados para preservar a privacidade dos envolvidos."

2) “'Você tem uma altura boa, Fabiana'. Cansei de ouvir essa lenga-lenga quando eu era gorda. Com 21 anos, eu media 1,85 metro e pesava $130 \mathrm{~kg}$. De tão grande, ganhei o apelido de muralha na escola."

3) "Sou casada há um ano e meio mas já estou com meu marido há oito anos. Somos muito, digamos, animados sexualmente. Eu ainda mais. Por mim transo de manhã e à noite. Todos os dias. E o Marcel tem o mesmo pique que eu. Ainda bem! Mas já teve dias em que brigamos porque eu queria transar e ele estava cansado. Aí eu ficava de cara feia, rolava discussão. Com o tempo percebi 
que dormir abraçadinho é bom também. E o casamento precisa de carinho, além de muito sexo, claro!"

4) "Eu trabalhava há seis meses no posto de gasolina quando me mandaram embora. Soube depois que o motivo da demissão foi absurdo. Eu era muito bom no que fazia e o gerente ficou com medo de perder seu lugar para mim. Recebi $\mathrm{R} \$ 700$. Fiquei desesperado porque minha mulher estava grávida de seis meses. Eu não podia ficar sem dinheiro."

5) “Conheci o Anderson* numa sala de bate-papo. A conversa não me chamou a atenção no começo. Ele disse que se sentia sozinho, que procurava alguém na net... Me interessei quando soube que ele entendia de carros. Queria fazer o meu Chevetinho funcionar.

* Nome alterado para preservar a privacidade do personagem."

Embora o tom geral dos textos seja de uma narrativa mais informal, alguns elementos característicos do formalismo da escrita também aparecem nos textos. Assim, termos como "pra", "daí", "tava", "se vira" convivem com "Lembrei-me”, “Peguei-o".

Os diálogos não são freqüentes e quando aparecem, em geral, resumem-se a uma única frase entre aspas. Das edições analisadas, a única que traz um diálogo mais longo é "Meu namorado me traiu comigo mesma", em que aparece:

“No minuto seguinte, apareci na frente dele como eu mesma:

- Você não ia fazer trabalho?

- Me deu vontade de comer comida chinesa e vim comprar.

- Ah, eu tenho que comprar o presente de aniversário. Vamos?

- Não, amor, pode ir sozinha. Vou comprar a comida e voltar. 
Sei. Saí de perto do Anderson. Vinte minutos depois apareci de novo. Ele ficou tenso. E eu, com toda postura, Ihe dei um beijo no rosto e disse:

- Vamos?

- Vamos aonde, meu amor?

- Eu sou a Paula.

- Eu não acredito que você fez essa criancice, Valquiria!

- E eu não acredito que você tava de caso há um mês com outra garota e agindo comigo como se nada estivesse acontecendo!"

Os encerramentos, conforme o informado pela editora Flávia Martinelli na entrevista, trazem um tom positivo de quem conseguiu superar um problema, sair por cima de uma situação negativa ou resolver algo. Reproduzimos os últimos parágrafos de cada matéria analisada:

1) “Estamos juntos há quase um ano e vamos nos casar. Eu voltei a morar com meus pais e estou fazendo faculdade de tradução. Não me arrependo do que fiz, porque aprendi muito sobre os homens vendendo meu corpo. E aqui, conto tudo o que descobri. Confira!"

2) "Minha transformação foi tamanha que as pessoas que não me conheciam não acreditam que eu era gorda mesmo depois de ver minhas fotos. E pensar que tudo isso começou por causa de uma blusa que eu nem tenho mais."

3) "Hoje valorizo muito mais os momentos de carinho com meu marido e respeito quando o Marcel chega cansado. Tenho que respeitar. Assim como ele também tem que respeitar a minha natureza. A grande verdade é que achei o homem certo para mim. E que dificilmente vai me trair, né? Ele não teria tempo! Nem energia." 
4) "Além de ter retorno financeiro, também fiquei famoso aqui no Espírito Santo. Já fui capa de jornal, fui a programa de TV e sempre sou chamado para dar palestras sobre negócios em faculdades e para outros jornaleiros. Como vendo muitas Sou + Eu! nas minhas bancas, achei que minha história poderia inspirar os leitores. Ah, peço a eles que torçam por mim. Se tudo continuar dando certo, ano que vem abriremos uma revistaria."

5) “Depois de muita discussão, terminamos. O Anderson teve o que mereceu. Acho que vai pensar duas vezes antes de enganar alguém pela internet."

\section{b. Conclusões}

Como sua proposta é só trabalhar com contribuições dos leitores, o espaço destinado por Sou + Eu! ao público é total, embora nem tudo sejam histórias de vida e relatos de experiências vividas. Essas narrativas dividem espaço na publicação com dicas de beleza, moda, piadas e consultório, entre outros. Mas são as matérias que recebem maior destaque, inclusive na capa da publicação.

A mediação aparece na seleção do que publicar e na reconstrução do relato a partir de entrevistas realizadas com o leitor/autor. Os textos resultantes desse processo tentam reproduzir elementos da linguagem própria dos entrevistados, procurando evitar a padronização.

As adequações pertinentes ao meio impresso também estão presentes, com a adoção de elementos gráficos (olhos, boxes, fotos) e o enquadramento no tamanho destinado à seção. As adequações são realizadas pelos profissionais da publicação. 


\section{Que Saudade de Você! - Programa Eli Correa - Rádio Capital}

O quadro, um dos mais tradicionais do rádio paulistano, teve início há quase 30 anos (1978) e hoje é líder absoluto de audiência no rádio em seu horário. Na época era intitulado de "Recado Musical" e surgiu porque era comum os ouvintes mandarem cartas oferecendo músicas para alguém e falando um pouco de sua história. O produtor do quadro, José Roberto Gama ${ }^{146}$, explica que o quadro lembrava um pouco o serviço de alto falante dos antigos parques de diversões, em que o locutor mandava recados dos enamorados:

“No caso do Eli não era exatamente assim, mas um pouco parecido porque ele dizia assim: 'Oiiii Gente... Tenho em mãos carta do ouvinte (Fulano de Tal) que está sofrendo muito, porque a sua namorada (Fulana de Tal) o trocou por outro. Ele diz aqui que não dorme direito, que não tem vontade de se alimentar, tudo isso porque você o deixou. O pobre rapaz está muito aborrecido. Ele quer que você volte pra ele, e toda vez que ouve a música que vocês ouviam juntos, então ele... chora, sofre mais ainda. Ele pede uma chance... Pelo menos pra conversarem. A música que faz ele lembrar de você é esta....' (toca a música pedida e que marcou o namoro do casal)."

O produtor explica que inicialmente eram cartas que vinham com poucas linhas, mas que com o passar do tempo foram ficando mais longas. O número de cartas também cresceu e o quadro passou a se chamar primeiro "Carta da Saudade" e finalmente assumiu o nome de "Que Saudade de Você!".

O quadro recebe cerca de 80 a 90 cartas por semana e passam por uma seleção feita pela produção do quadro para irem

${ }^{146}$ Entrevista concedida por e-mail à autora da tese. Disponível no Anexo 6. 
ao ar. No entanto, a seleção não é rigorosa. José Roberto Gama explica como se dá o processo:

“Não existe um critério rigoroso. Todos que escrevem são merecedores de muita atenção, afinal gastam com selo. Também tem o fato de tirar um tempo pra escrever sua carta, e isso tudo tem que ser reconhecido pela produção. Não existe sorteio de escolha de cada carta, o que acontece é que nem sempre é possível dar vazão imediata a esse volume tão grande de correspondência, mas nós sempre mantemos contacto com quem escreve, pois as pessoas colocam endereço, CEP e telefone também."

De todos os casos escolhidos para a análise, o “Que Saudade de Você!" foi o único que citou o interesse do próprio autor em ver sua história narrada como um critério de seleção, ao invés do interesse que sua história poderia causar nos demais ouvintes. No entanto, apesar da declaração do produtor de que há a intenção de atender a todos dentro das possibilidades, o volume de cartas recebidas ( 80 a 90 ) em comparação ao número de edições veiculadas (cinco) semanalmente, indica que a seleção por parte da produção do quadro de fato acontece.

Depois da seleção, as cartas passam por edição feita pelo próprio produtor. Segundo ele, o objetivo é corrigir os erros dos ouvintes e organizar as informações:

"O ouvinte escreve do jeito dele, e sendo assim, às vezes no auge da emoção do que está contando, se atrapalham, já colocam o final da carta em lugar que ainda não é o momento, pulam linhas, invertem nomes, erram nas datas, além da caligrafia não ser das melhores, e se não prestarmos atenção, corremos o risco de não agradar quem a escreveu. Porém não fugimos do fato, da história, tudo é questão apenas de correções necessárias."

Outra adequação é a incorporação dos efeitos de sonoplastia em complementação à interpretação feita pelo 
apresentador, que improvisa em cima da carta recebida, reforçando pontos, enfatizando certos trechos.

A narrativa também sofre alterações para se adequar ao tempo do quadro (cerca de 30 minutos). Quando a carta escrita é muito longa, é dividida em dois programas, mas isso é uma prática rara porque, segundo o produtor, os ouvintes querem saber o final da história e não gostam do suspense até o dia seguinte.

Também rara é a participação do autor, ao vivo, no programa. No entanto, às vezes isso acontece para que o ouvinte complemente algo que esqueceu ou para dar seu testemunho, reforçando a credibilidade da história.

O quadro também omite o nome do autor da carta quando solicitado, divulgando apenas as iniciais e o bairro.

\section{a. Edições analisadas}

Foram acompanhadas as cinco edições do quadro "Que saudade de você!" no período de 22 a 26/10/07. As cinco histórias foram:

1) Programa de 22/10/07 - Saudades de Claudionor dos Santos, falecido em 05/08/07 - história enviada pela ouvinte Maria Cícera Rosa dos Santos, do Jardim Laura, São Bernardo do Campo - SP, irmã de Claudionor. Duração total: 26 minutos.

2) Programa de 23/10/07 - Saudade de Ângela (sem divulgação do sobrenome) - história enviada pelo ouvinte Fabiano Vieira Garcia, de Jabaquara, São Paulo - SP, marido de Ângela. Duração total: 35 minutos e 20 segundos.

3) Programa de 24/10/07 - Saudades de uma fase feliz de sua família - história enviada pela ouvinte Alessandra (sobrenome não 
divulgado), de Cangaíba, São Paulo - SP. Duração total: 36 minutos e 40 segundos.

4) Programa de 25/10/07 - Saudades de Fernando Santos da Silva, falecido em 24/08/07 - história enviada pela ouvinte Flávia Santos da Silva, de Interlagos, São Paulo - SP, irmã de Fernando. Duração total: 30 minutos.

5) Programa de 26/10/07 - A história do casamento realizado no dia anterior (25/10/07) entre Antônia Nunes (internada em estado grave), de 17 anos, e Derivaldo Jovino da Silva, 31 anos, de Goiás - não foi informado quem era o autor da carta. Duração total: 29 minutos e 30 segundos.

A estrutura de apresentação é sempre a mesma: em torno das $14 \mathrm{~h}$ (horário do quadro), o apresentador começa a anunciar o quadro enquanto entrevista anunciantes e ouvintes que tenham usado o produto que está sendo promovido. O clima de depoimento começa a ser criado. Entre 14 h05 e 14h10, Eli Correa anuncia: "Em nome de (diz o nome do patrocinador)..." e entra a vinheta do programa. Em seguida ele diz "(Patrocinador) apresenta..." e entra a vinheta de "Que Saudade de Você!".

Embora o nome vincule o quadro à questão da saudade, seus temas são mais amplos tendo em comum o drama ou como costuma dizer o apresentador Eli Correa no final do quadro "mais uma história que a vida escreveu".

Nos casos analisados, temos a questão da perda de um ente querido como temática principal (norteou três das cinco histórias). Também aparecem a história de amor com final trágico anunciado em que o casamento ocorre com a noiva desenganada pelos médicos e a trajetória de uma família marcada pela perda de status, condição financeira e, finalmente, sua dissolução. Mas ao longo das narrativas, vários outros elementos do cotidiano da vida 
humana aparecem como o casamento, a mudança de emprego ou cidade, a construção do lar, as relações entre familiares.

As temáticas (amor, morte, perdas) estão presentes também nos demais quadros do programa, demonstrando que há critérios comuns para a seleção do que é veiculado. No entanto, a carga de drama (determinada pelo conteúdo da história e reforçada pela interpretação do narrador e pelos efeitos de sonoplastia) é maior nesta parte.

O quadro é o maior entre os fixos do programa, ocupando cerca de $17 \%$ do total diário. Além da duração, a ênfase que é dada ao quadro, durante o programa e nas propagandas sobre ele (na própria rádio e no site), demonstra a importância que ele tem dentro da estrutura.

Quanto às narrativas, não há um início padrão, como é possível verificar na transcrição ${ }^{147}$ que fazemos a seguir dos primeiros 30 segundos de cada história:

1) “Eu e meus irmãos nascemos e nos criamos na Bahia. O pai tinha um alambique e nós, seus cinco filhos, e nossa mãe, trabalhávamos na roça. Foi num fim de tarde que o pai chegou, jantou e foi logo se deitar para no dia seguinte enfrentar mais um dia de trabalho. Ele sempre foi o primeiro a pular da cama mas nesse dia não aconteceu isso."

2) "Eu tinha saído do meu trabalho e ia pegar o ônibus que me levava para casa. Quando estou subindo a rua, à minha frente seguia uma moça que logo eu percebi era cega. Essa moça ia se guiando pela calçada com a sua bengala, batendo prá lá e prá cá, como fazem todas as pessoas que não têm visão. Essa moça já estava alcançando a esquina e ia em frente para atravessar a rua."

${ }^{147}$ Nas transcrições, foi respeitada a forma com que o texto foi lido. 
3) "Eu sou a mais velha de três irmãos. Hoje eu tenho 26 anos, casada, e mãe de uma criança de dois anos. Minha infância foi muito boa, muito feliz. Meu pai trabalhava numa firma grande e podia nos proporcionar excelente conforto. Tínhamos uma casa enorme, ótima, carro do ano e viajávamos sempre nos finais de semana. Mas essa boa condição de vida acabou gerando inveja em certas pessoas."

4) "Maria de Lourdes e João. Um casal que gerou onze filhos. Quando éramos pequenos, sofremos a perda de uma das meninas, a Fabiana, que então tinha seis anos. E o meu pai e a mãe ficaram muito, mas muito tristes. Maria de Lourdes e João. Nessa época, meu irmão, o Fernando, que sempre foi muito ativo e esperto começou a trabalhar para ajudar o nosso pai e a nossa mãe."

5) "Antônia. Antônia, desde menina, ela ficava encantada quando via uma noiva. Quando ela via uma noiva, Antônia ficava encantada. Aliás, prá ser sincero, todas as meninas e adolescentes ficam de fato deslumbradas quando vêem uma noiva. Quando você vê uma noiva num carro: olha uma noiva, olha uma noiva, olha uma noiva... Quando você passa em frente a uma igreja, a noiva está ali esperando para entrar: olha a noiva, olha a noiva..."

Apenas duas das narrativas começam já na temática principal da carta: a família que tinha tudo, mas que sofre a inveja das outras pessoas (terceiro caso) e o sonho de se casar de uma moça (do quinto caso). As outras três começam com o histórico das famílias (primeiro e quarto casos) e da relação de amor (segundo caso).

As histórias todas têm personagens principais que raramente são os autores das cartas, embora nas histórias de amor, em geral, os autores sejam os parceiros desses 
personagens ${ }^{148}$. Esses personagens principais (Ângela, na segunda história; a família de Alessandra, na terceira; Fernando, na quarta; e Antônia, na quinta) estão presentes logo no início da história. Já a história de Claudionor (da primeira carta) é iniciada com um fato mais antigo que foi a perda do pai deles.

No entanto, mesmo quando não se inicia com a trajetória do personagem em si, os fatos narrados estão fortemente relacionados com a história principal.

Não há variações na construção do relato, sempre começando pelos fatos mais antigos e seguindo a história cronologicamente até o seu desfecho, o que confirma que há, por parte da produção, uma reorganização da narrativa, impondo um padrão narrativo para o quadro.

A estrutura do "Que Saudade de Você!" traz alguns pontos fixos como a repetição, utilizada pelo apresentador tanto para ir fixando os elementos principais da história quanto para enfatizar o aspecto dramático de alguns trechos - em particular do desfecho. Esses fatos mais importantes que são repetidos pelo apresentador e, em particular, o desfecho da história são ressaltados também pela sonoplastia.

Nos casos analisados, encontramos os principais exemplos dessa repetição:

1) A dedicação de Claudionor à mãe em detrimento à própria vida pessoal é ressaltada em vários pontos pela irmã; as dores de cabeça que indicam o problema de Claudionor aparecem e vão se destacando na narrativa; a revelação do problema grave de saúde; o desgaste de exames e tratamentos até o estado terminal e, por fim, o desfecho que transcrevemos: "Em dado momento nesse dia

\footnotetext{
${ }^{148}$ Usamos o termo em geral já que na quinta narrativa não foi informado o autor da carta.
} 
5 de agosto de 2007, em dado momento, eu senti uma angústia... mas eu senti uma tristeza dentro de mim, do meu coração, que veio um choro, mas veio um choro, um choro... eu pensei até que fosse ter uma coisa. Mas dali a pouco eu melhorei. Aquele estado assim foi passando, como se eu estivesse voltando a mim. E pensei: é um aviso. Só pode ser um aviso. Ele deu um sinal. Eu tenho certeza que ele partiu para Deus. Eu tenho certeza, isso que eu senti, esse aperto no meu coração, essa angústia, essa vontade de chorar, eu tenho certeza, eu tenho certeza, foi um aviso, foi um aviso... pois não demorou nada, pois não demorou cinco minutos, o telefone toca... eu dei um pulo e ao atender, veio a bomba: 'Lia, Claudionor acaba de falecer. O Claudionor acaba de morrer, Lia'. Eu senti o aviso, eu senti. Eu estava assim e do nada veio aquele aperto no coração, veio aquele choro convulsivo, sabe, do nada... aquilo era um aviso!"

2) A deficiência visual de Ângela; o interesse imediato de Fabiano e o início do relacionamento; o casamento e o sonho de ter um filho; os problemas na gravidez até o desfecho: “E estranhei uma correria que houve em um determinado dia. Em um determinado momento, eu estranhei uma correria que houve. Ângela foi levada ao quarto de emergência, à UTI, só que não havia nenhuma notícia. Eu estou vendo aquela correria, só que eu pergunto e ninguém me dá ouvidos, ninguém me dá resposta. Eu fiquei em completo desespero ao lado dos meus pais e ao lado dos meus sogros. Nesta altura, ela já estava de sete meses e meio. As horas iam passando e aquela angústia, aquela ansiedade, ninguém dá informação, ninguém informa nada. Meu Deus do céu, ninguém dá informação da minha mulher, ninguém dá informação da minha esposa. E demorou muito até que o chefe da equipe médica que estava atendendo Ângela me chamou. E eu fui com meus pais e com meus sogros até aquela sala em que o médico me chamou. E 
foi quando veio a bomba. E foi quando veio a bomba: 'A criança nós conseguimos salvar. Aliás, ela já foi levada para a incubadora. A mãe entrou em óbito.' Não, meu Deus; não, meu Deus; não, meu Deus; não, meu Deus. Não, doutor, não, não pode, não pode, não. Não, meu Deus, não. Não, Ângela, não."

3) A prosperidade da família despertando a inveja das pessoas próximas; os sucessivos problemas e as perdas financeiras; as tentativas de recuperação; e o ápice: “De uma hora para outra, minha mãe resolveu fazer algo que ia deixar meu pai completamente desesperado. Minha mãe fez uma coisa que tirou meu pai de órbita. Minha mãe, simplesmente, abandonou tudo e foi embora! Depois de tudo isso, desses anos todos de casada, um dia dá a louca da minha mãe de abandonar meu pai. E olha que meu pai estava construindo já em São Paulo, estava indo bem em Jundiaí. Mas ela abandonou tudo. Me lembro que ela passou em casa dizendo que ia visitar sua mãe, no caso minha avó, que estava doente, lá na Bahia, e dali uns dez dias estaria de volta. Ainda perguntei se o pai tinha concordado e ela me disse que sim. Só que não falou nada com ele. Ela foi embora assim meio fugindo, como assim fugindo. Mas ela passou aqui e disse que o pai sabia, que o pai concordou. Os dez dias se passaram e ela não voltou mais. Deixou tudo para trás, assim de repente. Com isso, o pai perdeu o emprego em Jundiaí: o patrão não aceitou minha irmã que era muito nova, 17 anos, no lugar de minha mãe. E isso que minha mãe fez abalou meu pai de tal modo, de tal maneira... Ele não se conformava, ele não entendia... 'Sabe, eu não consigo entender porque a sua mãe fez isso. Que que aconteceu que virou a cabeça da sua mãe? Que sem mais nem menos vai embora, não avisa, passou na sua casa, disse que ia para a Bahia, dez dias depois estaria de volta...Que aconteceu com a sua mãe?' Ele não 
se conformava... E papai emagreceu sete quilos assim, de uma hora para outra."

4) A dedicação do irmão à família, o empenho no trabalho; a paixão por motocicletas; a separação dos pais; os sucessivos acidentes; e o auge do drama: "24 de agosto - 2007, faz dois meses... dois meses atrás... duas horas da tarde desse dia. 0 celular toca, ele foi chamado para fazer uma entrega. Muito embora ele não quisesse mais ser motoboy e sim ter a firma que ele estava montando de motoboy. Mas nesse caso ele foi fazer a entrega. Ele se despediu e saiu. No fim da tarde, minha irmã chega em casa desesperada, dizendo que o nosso irmão havia sofrido um acidente. E ela soube desse acidente porque a Tatiane, sua namorada, havia ligado prá ela. Na mesma hora liguei pro celular do Nando e tocou, tocou até que finalmente atenderam. Não era meu irmão. Era uma pessoa do resgate. Eu me identifiquei, falei que era irmã dele, queria saber o que tinha acontecido, como o meu irmão estava, se tinham levado ele prá algum hospital, eu queria o endereço... Eu estava em pânico, a família estava em pânico. '- Por favor, calma', disse o resgate. '-Nós chegamos agora com o resgate e ele está caído aqui no chão. Tem médico examinando o estado dele mas é necessário que a família venha para cá. A situação, infelizmente, é muito grave'. Eu e toda a família, cada um saindo de um ponto da cidade, tentávamos chegar ao lugar indicado: Marginal Pinheiros, altura da Ponte Morumbi. O trânsito estava horrível, carros parados, buzinas, trânsito congestionado e na nossa cabeça, a tormenta e na nossa cabeça, o desespero. Porque aquele trânsito bem possivelmente estava sendo provocado pelo acidente lá na frente, acidente com nosso irmão, acidente com o Nandinho, acidente acontecido na Marginal Pinheiros, altura da Ponte Morumbi. O trânsito horrível, carros parados, buzinas, congestionado...Aos poucos fomos 
conseguindo nos aproximar e realmente o carro do resgate estava lá, a polícia... Eu não agüentei, eu não agüentei... Como estava parado o trânsito, eu não vou ficar dentro do carro, sabendo que o Nandinho está lá, eu vou descer do carro e vou à pé... Eu desci do carro, corri prá lá e quando eu cheguei perto, louca, já esperando o pior, sei lá, no que eu cheguei lá, eu desmaiei... no que eu cheguei lá, eu desmaiei... Havia um corpo estirado, encoberto por um pano. O pessoal do resgate não queria que eu erguesse o lençol... '- Mas eu sou irmã, eu sou irmã. É meu irmão, é meu irmão!'. Então eu fui empurrando um, empurrando outro e quando eu ergui o lençol que cobria aquele corpo, entrei em estado de choque. Meu irmão morto! Eu abaixei do lado: '- Fala comigo, Nandinho! Pelo amor de Deus, fala comigo! Você não pode deixar a mãe, não pode deixar a gente! Levanta, meu irmão, levanta! Você não pode morrer!'”

5) O sonho de casar de Antônia; o encontro e o namoro com Derivaldo; a descoberta da doença e de sua gravidade; e o ápice da dramatização: “E ontem, 10 da manhã, a irmã Beatriz, da Irmandade do Sagrado Coração de Maria, executa os primeiros acordes da marcha Nupcial e a porta da Capela, a Capelinha do Hospital das Clínicas de Goiânia, que não é tão imponente como a porta de uma matriz, de uma igreja... mas aquela porta se abre e se torna grande diante da celebração, do ato, e todos se levantam, todos olham para a porta: é Antônia Nunes, 17 anos agora... ela conheceu Derivaldo com 16. Ela está de braços dados com o pai, o Sr. Ernesto. Nas mãos um buquê simples, simples, como ela pedira. Ela olha fixo em direção ao altar e lá está Derivaldo J ovino da Silva, seu noivo, de 31 anos, e ela então começa a caminhar. O seu sonho vai se realizando, o seu sonho de menina, quando tantas vezes ela viu uma noiva caminhando ali para aquele centro da Igreja... agora é ela, é ela realizando o seu sonho. Os olhares 
de emoções se cruzam porque todos sabem o seu estado de saúde, todos sabem as suas condições. A Marcha Nupcial vai empurrando Antônia em direção ao grande amor de sua vida. A maioria das pessoas ali presentes está chorando. Ninguém consegue praticamente conter as lágrimas porque todo mundo sabe o seu estado de saúde. A capela é pequena - é uma Capela. Alguns passos e ela chega já no altar. E Derivaldo desce os dois degraus que separam o altar dos convidados, beija a testa de Antônia, estende o braço esquerdo e a conduz diante do sacerdote. Tem início então o ato derradeiro da cerimônia, com o padre unindo os dois corações."

É importante lembrar que a repetição é uma técnica muito utilizada no rádio quando se pretende fixar alguma informação já que por sua característica de instantaneidade, o meio radiofônico exige a compreensão imediata da mensagem pelo público. Ao mesmo tempo, a utilização de efeitos sonoros e música são elementos constituidores da linguagem radiofônica ${ }^{149}$. Assim, essa adequação na narrativa é fruto indiscutivelmente de uma necessidade do meio.

Também são utilizados os diálogos (elementos de narrativa ficcional) entre os personagens, todos interpretados pelo apresentador.

O mesmo recurso (a repetição) é utilizado para completar o tempo da história quando a narrativa não é tão longa. Isso acontece nos casos um (a história é resumida em três minutos antes do encerramento), quatro (o resumo dura quatro minutos) e cinco (o resumo é feito em vários trechos até o final).

149 Os elementos constituintes da linguagem radiofônica são: a palavra, a música, os efeitos sonoros e o silêncio (BALSEBRE, 1994:27) 
O encerramento do quadro só segue uma padronização que é a veiculação da vinheta. Algumas vezes, a história acaba na própria voz de Eli Correa (casos um, quatro e cinco), outras com uma música (casos dois e três). Um dos casos, o da família de Alessandra (caso três), trouxe ainda uma entrevista ao vivo com a autora da carta para que ela confirmasse os problemas narrados e pedisse ajuda. Depois, durante a música solicitada, o apresentador voltou e colocou no ar, também ao vivo, outra ouvinte que se dispunha a ajudar a desfazer a "amarração" contra a família e por fim, encaminhou as duas para a produção fazer a mediação.

A narrativa final também não segue um padrão. Transcrevemos os últimos trechos (minuto final) da narrativa feita por Eli Correa:

1) "Claudionor, descanse em paz. A mim, a nós, seus irmãos, a mãe, a todos que te conheceram só podemos dizer: Que saudade de você! E olha, onde você estiver, a promessa que eu fiz, estou cumprindo hoje. Lembra quando você me pediu que se acontecesse de você morrer, você queria que eu escrevesse uma carta para o Eli Correa? Então, é uma homenagem que eu faço a você e aproveito para agradecer a toda a equipe médica de neurologistas do Hospital Heliópolis. Eu, Maria Cícera Rosa dos Santos, Jardim Laura, São Bernardo do Campo: Que Saudade de Você!"

2) “As lembranças, as saudades, são muito grandes, Ângela. Você foi meu grande amor e continua sendo. Aqui dentro do meu peito, do meu coração, Ângela, Ângela, que saudade de você, minha querida! Até um dia quando nos encontraremos de novo! Até um dia, meu amor. Até um dia, minha querida. Até um dia, minha princesa... Fabiano Vieira Garcia, bairro do Jabaquara. Que Saudade de Você! Rádio Capital - mais uma história que a vida 
escreveu! Mais uma história que o amor, e só o amor, poderia ter escrito! E desse amor, um fruto, Lucas! Que Saudade de Você!"

3) "Talvez hoje, talvez a gente chegue à conclusão de que tudo isso já fazia parte do despacho, daquela maldade. Porque pro meu pai fazer tanta coisa, só podia já ser fruto da amarração que estava sendo feita e depois culminando com a minha mãe indo embora. 28 anos de casada. Eu sou Alessandra, aqui de Cangaíba. Foi meu pai que pediu para eu mandar essa carta. Foi meu pai que pediu para eu escrever esta carta prá ver se, através desta carta, quem sabe, encontre alguém para desamarrar. Porque ele falou que a minha bisavó tem aparecido muito para ele, uma bisavó que ele mal conheceu, dizendo que a vida dele e da mulher dele, minha mãe, está amarrada. 'A vida está amarrada. Precisa desamarrar, precisa desamarrar'. Porque se isto não acontecer, meu pai vai acabar morrendo. E foi atendendo ao pedido dele que eu mando esta carta. E quem sabe através desta carta, eu encontre alguém que possa fazer isso, que possa desamarrar. '-Alô? - Alô. -Quem fala? - Alessandra, Eli Correa."'

4) "Nascido no dia 11 de agosto de 1983. Faleceu no dia 24 de agosto de 2007, em um acidente gravíssimo de moto, na Marginal Pinheiros, próximo à Ponte Morumbi. Profissão: motoboy. Enterrado no cemitério do Campo Grande, Santo Amaro. Gostaria que esta carta fosse narrada na seção Que Saudade de Você! Desde já agradeço e pediria também, se possível, que esta carta seja gravada para que tenhamos esta gravação, para que recordemos por todo o sempre a homenagem que fizemos ao meu irmão Fernando Santos da Silva na seção Que Saudade de Você!"

5) “Na cabeça de Antônia, ficou gravada a mensagem mansa e suave do padre ao dar a benção nupcial: 'em nome de Deus, em nome do Pai, em nome do Filho, em nome do Espírito Santo, eu 
vos torno marido e mulher'. Antônia e Derivaldo - até que a morte os separe. Rádio Capital - Antônia, imediatamente ao casamento feito ontem, às 10 da manhã, foi desenganada pelos médicos. (toca música "Love is a many splendored thing") O amor, a coisa mais esplendorosa que existe no mundo, o amor entre um homem e uma mulher, o amor que une duas pessoas e as transforma em uma só. Até que a morte os separe. Derivaldo e Antônia - Pai, Filho e Espírito Santo. Amém. Rádio Capital - mais uma história que a vida está escrevendo. Em estado grave, gravíssimo, leucemia, 17 anos, não queria morrer sem antes realizar o seu sonho, o sonho do casamento. Capital - Que Saudade de Você!"

\section{b. Conclusões}

O espaço dedicado ao relato das histórias pessoais do próprio público pelo programa Eli Correa é significativo e, pelo tempo em que está no ar, um dos mais consistentes do rádio paulistano.

A análise mostra que, sob o ponto de vista da mediação, os dois níveis principais, a seleção e a escolha da linguagem para a narrativa, estão fortemente presentes no quadro, assim como as adequações realizadas em função do meio (adoção de elementos próprios da linguagem radiofônica e adequação ao tempo fixado para o quadro) também são efetuadas. Tudo isto fora do controle do autor inicial do relato.

A seleção dos casos obedece aos critérios de noticiabilidade adotados pelo programa: histórias, notícias, músicas que mexam com a emoção do público. 


\section{Casos de Família - SBT}

O programa do SBT estreou há três anos e atualmente é veiculado de segunda a sexta, às $18 \mathrm{~h}$, com uma hora de duração. A apresentação é da jornalista Regina Volpato. O formato foi comprado de uma produtora chilena que já trabalha com isso há dez anos em seu país.

No site da rede televisiva, o programa aparece como um talk show ${ }^{150}$, ao lado do "Programa Hebe". As demais classificações são: Novelas, Filmes, Humor, Reality Show, Infantil, Jornalístico, Séries, Telejornal e Variedades.

A proposta é trazer pessoas do próprio público para falar de questões do dia-a-dia, em geral, pautas de comportamento. Segundo o diretor do programa, Galvão França, os temas são definidos pela própria equipe do programa:

“Nós temos uma equipe de estagiários que recebem os temas dados por nós e vão em busca dos casos. Estes casos são entrevistados por eles e depois novamente entrevistados por uma equipe mais experiente, se o caso se encaixar no tema, tiver consistência e for verdadeiro, entra no programa." ${ }^{151}$

Os telespectadores podem se inscrever para participar ou sugerir temas para os programas. Os anúncios solicitando inscrições e sugestões são feitos tanto durante o programa quanto no site ${ }^{152}$. Mesmo assim, ressalta o diretor, na maioria das vezes, os temas são criados pela própria produção do programa.

\footnotetext{
${ }^{150}$ Programa baseado na condução de entrevistas pelo(s) apresentador(es) com um ou mais entrevistados. O tema pode ser único ou variado.

${ }^{151}$ Entrevista concedida por e-mail à autora desta Tese. Disponível no Anexo 7.

152 http://www.sbt.com.br/casos_familia/
} 
Quanto às contribuições do público, relatos das próprias experiências de vida, elas são arquivadas e podem ser aproveitadas posteriormente em programas em que se encaixem.

Segundo Galvão França, a seleção dos participantes é feita em várias etapas e, em cada uma delas, eles recebem notas. São os personagens com maior pontuação que são escolhidos para participar do programa. Nas entrevistas há a preocupação de checar se os casos são realmente reais.

A temática dos programas é livre e não há restrição a assuntos ou enfoques. No entanto, a tônica do programa é abordar situações que geram conflitos ou dificuldades para os relacionamentos cotidianos (familiares, de trabalho, da vizinhança...).

O programa trabalha sempre com mais de uma história sobre o mesmo tema, cada uma apresentada por uma dupla. Além dos protagonistas dos casos apresentados, a platéia também participa, debatendo ou opinando sobre as situações vividas.

O programa é gravado e os participantes, antes da gravação, passam por uma revisão com a produção do programa. Segundo Galvão França, o objetivo dessa revisão é tentar deixar claro "os pontos mais importantes de cada história" que foram levantados nas entrevistas.

Apesar do programa apresentar os conflitos entre os participantes por causa do assunto/comportamento debatido no dia, há restrições quanto ao comportamento desses participantes:

“A única restrição que o formato impõe, é com relação à ética e educação, o programa não permite xingamentos e palavrões, pois o intuito do programa não é promover a baixaria e xingamentos." 
Ao final de cada programa, um psicólogo comenta as atitudes e situações dos participantes e dá "conselhos" sobre como agir.

\section{a. Edições analisadas}

1) "Seu casamento acabou e só você não percebe" - dia 22/10/07 - participantes: Telma, 33 anos e Rosângela, 26 anos, irmãs; Salete, 45 anos e Solange, 47, irmãs; Joselina, 39 anos e Rita, 22, mãe e filha.

2) "Você tem inveja de mim é o nosso tema de hoje" - dia 23/10/07 - participantes: Vanusa, 19 anos e Gisele, 25, amigas; Danila, 22, e Joice, 20, amigas; Luciana, 34, e Nina, 20, cunhadas; Tatiane, 19, e Viviane, 17, amigas.

3) "Minha namorada não me deixa fazer nada" - dia 24/10/07 participantes: Mário, 21 anos, e Michele, 18, namorados; Saulo, 19, e Nena, 19, namorados; Marcos, 27, e Sandra, 24, namorados; Raul, 19, e Cristina, 18, namorados.

4) "Eu acredito no meu talento" - dia 25/10/07 - participantes: Almir Ricardo, 31 anos e Adriano, 26, amigos; Fábio, 24, e Patrícia, 25, irmãos; Félix, 35, e Valéria ,21, cunhados; Ramyres, 41 , e I raci, 39, casados.

5) "Minha família não tem obrigação de nos ajudar" - dia 26/10/07 - participantes: Jerry, 36 anos, e Sandra, 40, casados; Fabiana, 25, e Carlos, 32, casados; Paulo, 41, Mara, 40, casados; e Terezinha, 44, e Antônio, 41, casados.

A duração do programa "Casos de Família" é padronizada (uma hora) e seu formato também: é dividido em 
quatro blocos. Mas como trabalha com várias histórias, não há um tempo padrão para cada uma delas.

O início do programa é sempre com a apresentadora Regina Volpato explicando o tema, seguida da vinheta do programa e então o primeiro caso. A fala da apresentadora, em geral, resume a primeira história com detalhes que diferem, às vezes, das demais narrativas apresentadas. Reproduzimos a apresentação de cada uma das edições analisadas ${ }^{153}$ :

1) "Sua irmã é casada e sofre por causa do marido. Você gostaria que ela desse um fim nesse relacionamento e procurasse ser feliz de outra maneira. Ela diz que isso é apenas uma fase ruim. Você acha que ela está cega e que continuar nessa situação é só prolongar o sofrimento. Seu casamento acabou e só você não percebe é nosso tema de hoje."

2) "Tem gente que não consegue ficar feliz com as conquistas dos amigos e infelizmente a sua amiga é assim. Tudo que você tem ela quer, além de nunca te elogiar. Família diz que isso não é inveja, é admiração. Você acha que admiração é um sentimento muito diferente disso e que, ao invés dela perder tempo, querendo o que é seu, ela deveria correr atrás dos próprios sonhos. Você tem inveja de mim é o nosso tema de hoje."

3) "Namorar, sair com os amigos, bater uma bolinha no final de semana. É o que quase todo homem gosta de fazer mas com você isso é impossível porque a sua namorada não larga do seu pé. Ela diz que faz tudo isso porque não pode deixar você solto. Você gosta dela e quer que a relação seja duradoura mas gostaria de poder conversar e até conviver com outras pessoas sozinho, sem

\footnotetext{
${ }^{153}$ Nas transcrições, respeitamos a forma com que apresentadora e participantes falaram.
} 
ela por perto. Minha namorada não me deixa fazer nada é o nosso tema de hoje."

4) "Ser famoso muita gente quer e você está correndo atrás para realizar o seu sonho. Você diz que tem talento e que um dia vai fazer muito sucesso. O seu amigo não concorda e diz que isso tudo é ilusão porque você nem é tão bom quanto pensa ser. Você ignora os comentários maldosos e continua firme na sua caminhada em busca do reconhecimento e do sucesso. Eu acredito no meu talento é o nosso tema de hoje."

5) “Você se casou e assumiu uma família. Apesar das necessidades, acredita que vocês têm que se virar sozinhos. Sua mulher não concorda e vive pedindo coisas para a sua família, porque acha que eles têm mais condições e podem ajudar vocês. Você sente vergonha, se irrita, não gosta que ela faça isso e a faz devolver tudo o que pediu emprestado. Minha família não tem obrigação de nos ajudar é nosso tema de hoje."

São apresentadas em cada programa, três ou quatro histórias. Na primeira situação, cada história ocupa um bloco e o último é destinado a uma participação maior da platéia, assim como comentários mais extensos da apresentadora e do psicólogo convidado.

Cada história apresentada na edição é abordada sob o ponto de vista de dois protagonistas que são entrevistados primeiro separadamente e depois debatem com a apresentadora e o público. Ao anunciá-los (um de cada vez), a apresentadora informa a idade e resume em uma frase o que ele pensa da situação que está vivendo o que, em geral, é confirmado durante a entrevista. No entanto o vocabulário do entrevistado nem sempre acompanha o que é apresentado. Reproduzimos algumas das apresentações: 
1) Joselina, de 39 anos, diz: "A Rita e o marido não têm diálogo e no relacionamento deles não há sequer respeito e por isso é melhor que eles se separem."

2) Vanusa, de 19 anos, diz: "Outro dia fui visitar a Gisele e me deparei com o meu sutiã pendurado no varal da casa dela."

4) Patrícia, que está com 25 anos e diz: "Para ser ator, é preciso se dedicar e estudar muito, coisa que o Fábio não faz."

A entrevista nem sempre começa já pelo assunto; algumas vezes Regina Volpato inicia com perguntas gerais e 0 histórico do problema. Os entrevistados respondem às perguntas e vão apresentando sua versão. As falas em geral são curtas e a apresentadora faz várias perguntas a cada entrevistado. Selecionamos o início das entrevistas de uma história de cada edição, com as perguntas e respostas (cerca de 30 segundos cada):

1) Terceira história: Joselina e Rita, mãe e filha.

“Regina Volpato (RV): Agora a gente vai conhecer a Joselina, que está com 39 anos e diz: A Rita e o marido não têm diálogo e no relacionamento deles não há sequer respeito e por isso é melhor que eles se separem. Joselina, por favor, entre... Tudo bem, Joselina?

Joselina: Tudo bem.

(RV): Você é o que da Rita?

Joselina: Eu sou a mãe.

(RV): Mãe dela?

Joselina: Mãe dela. 
(RV): E quando ela foi casar, quando ela foi morar com esse rapaz, foi com o seu consentimento?

Joselina: No início, eu achei que ele fosse uma pessoa decente porque trabalhava numa fábrica de construção, onde é serviço pesado. Eu pensei: uma pessoa que trabalha em serviço pesado não pode ser uma pessoa indecente, tem que ser uma pessoa decente. Então, vamos ver o que vai dar.

(RV): Você acha que quem tem disposição prá trabalhar e pegar no pesado tem bom caráter, tem uma boa conduta frente à vida?

Joselina: Até então eu pensava assim, eu pensava assim.

( ...)

(RV): Então, vamos conhecer a Rita, que está com 22 anos e diz: 0 meu companheiro não conversa comigo e me agride, mas mesmo assim eu não penso em separação. Rita, por favor, entre. Tudo bem, Rita?

Rita: Tudo.

(RV): Um companheiro que não conversa não é esquisito?

Rita: Com certeza.

(RV): E um companheiro que agride também não é esquisito?

Rita: É, mas eu gosto dele.

(RV): Companheiro não é aquele que acompanha?

Rita: É.

(RV): Não é aquele que está junto?

Rita: Com certeza.

(RV): Você sente que ele está ao seu lado, junto de você? 
Rita: Tem horas que sim, mas tem horas que ele passa dos limites, ele quer me bater... Ele me xinga, ele xinga a minha família, xinga os meus parentes todos."

2) Quarta história: Tatiane e Viviane, amigas.

“(RV): Agora a gente vai conhecer a Tatiane que tem 19 anos e diz: A inveja da Viviane vai além de copiar meu estilo, eu acho que ela quer roubar o meu marido. Tatiane, por favor, entre. Tatiane, não é muito grave isso, você falar isso de uma pessoa: que quer roubar o seu... ela é casada?

Tatiane: Não.

(RV): Ela não é casada?

Tatiane: Não, o marido dela largou ela.

(RV): Não é muito grave você falar isso: eu acho que ela está querendo o meu marido...

Tatiane: Não... É o que parece.

(RV): Por que? Por que você acha isso?

Tatiane: Porque ela vive todo o dia mandando eu largar o meu marido, que era prá mim ir atrás de outra pessoa, que ganhasse bem... e eu não acho que meu marido ganha mal. E eu não vou largar o meu marido, porque eu amo ele.

\section{$(\ldots)$}

(RV): Então, vamos conhecer a Viviane que está com 17 anos e diz: Eu sempre encontro defeito em tudo que a Tatiane faz ou compra, mas isso não tem nada a ver com inveja. Viviane, por favor, entre... Tudo bem, Viviane?

Viviane: Tudo.

(RV): Vocês são amigas há quanto tempo? 
Viviane: Desde os 10 anos.

$(R V)$ : Desde os?

Viviane: 10 anos.

$(\mathrm{RV})$ : Dez anos?

Viviane: Humhum

(RV): E vocês são amigas prá valer?

Viviane: Sim.

(RV): Mas a Tatiane acha que você só põe defeito, que você quer as coisas dela, que às vezes você tá de olho no marido dela.

Viviane: Eu tento ajudar ela. Mas tudo que eu falo ela acha que eu tô dando palpite errado, que eu me intrometo muito na vida dela..."

3) Primeira história: Mário e Michele, namorados.

“(RV): Nosso primeiro convidado de hoje é o Mário, que está com 21 anos e diz: O ciúme da Michele cresce a cada dia e isso só atrapalha a nossa relação. Tudo bem, Mário?

Mário: Tudo bem

(RV): Faz quanto tempo que vocês estão juntos?

Mário: Quatro anos e dois meses.

(RV): Quatro anos e dois meses, marcadinho até os meses...

Mário: Tem que marcar, senão o bicho pega...

(RV): Os meses têm que marcar?

Mário: Se eu esquecer um mês, apanho.

(RV): Qual é o dia? Qual é o dia que vocês começaram a namorar? Mário: 27 de junho. 
(RV): Então, todo dia 27 você tem que falar: Michele, hoje a gente faz aniversário...

Mário: Tem que falar, senão o bicho pega...

(RV): Já esqueceu algum dia, não?

Mário: Já

(RV): E aí, o que ela fez?

Mário: Me bateu.

( ...)

(RV): Então vamos conhecer a Michele, que está com 18 anos e diz: Eu não permito que o Mário jogue futebol com os amigos, muito menos sem camisa. Michele, por favor, entre. Tudo bem, Michele?

Michele: Tudo bem.

(RV): Você nota que de dois anos prá cá você ficou mais ciumenta? Michele: Noto.

(RV): Mas me esclareça uma coisa, você ficou mais ciumenta, ou você só mudou o jeito de manifestar o seu ciúme?

Michele: Mais ciumenta.

(RV): Mais ciumenta?

Michele: Mais ciumenta.

(RV): O que que coisas que antes não te incomodavam, passaram a te incomodar, Michele?

Michele: Na escola. Prá mim ele tava olhando para as meninas e isso me incomodava. Daí, depois disso já começou a crescer o meu ciúmes."

4) Segunda história: Fábio, ator amador e a irmã, Patrícia. 
“Regina Volpato (RV): Agora a gente vai conhecer o Fábio que está com 24 anos e diz: Apesar de ter sido passado para trás várias vezes, eu ainda acredito no meu sonho. Fábio, por favor, entre. Tudo bem, Fábio?

Fábio: Tudo bem.

(RV): Que história é essa de ter sido passado para trás?

Fábio: Bom, tudo começou quando eu tinha sete anos de idade. Foi aonde eu comecei a fazer teatro, a pegar gosto pela área de atuar...

(RV): Foi por vontade própria ou contou com o incentivo dos seus pais?

Fábio: Não, vontade própria minha.

(RV): Com sete aninhos?

Fábio: Sete anos de idade.

(RV): E como você tomou contato com o teatro? Numa escola?

Fábio: Não, não sei se você conhece o Parque Ecológico do Tietê... (RV): Conheço.

Fábio: Lá tinha um Clube da Turma, aí foi onde eu comecei a participar.

(RV): Então, vamos conhecer a Patrícia, que está com 25 anos e diz: Para ser ator, é preciso se dedicar e estudar muito, coisa que o Fábio não faz. Patrícia, por favor, entre. Tudo bem, Patrícia? Patrícia: Oi.

(RV): Você acredita no talento do seu irmão, no talento do Fábio? Patrícia: Não. 
(RV): Não acredita?

Fábio interrompe: A família não acredita, você está vendo?

(RV): Por que que você não acredita?

Patrícia: Ele é muito engraçado. As pessoas gostam dele. Ele é alegre, divertido, extrovertido, ele confunde isso.

(RV): Não entendi. Ele confunde o que?

Patrícia: Ele confunde as pessoas gostarem dele... Assim, ele faz mais em bairro... Teatro ele apresenta na igreja... Então todo mundo já gosta dele... Daí quando vê: Fábio! Fábio! E ele se sente, sabe?

(RV): Então você acha que gostam do Fábio pessoalmente?

Patrícia: É, do Fábio pessoa, não o Fábio ator."

5) Primeira história: Jerry e Sandra, casados.

“(RV): Nosso primeiro convidado é o Jerry, que está com 36 anos e diz: Nós temos que nos virar sozinhos, por isso eu proibi minha mãe de dar as coisas à Sandra... Tudo bem, Jerry?

Jerry: Tudo bem, Regina.

(RV): Sandra é sua esposa?

Jerry: Esposa.

(RV): E o que está acontecendo que ela pede coisas para sua mãe?

Jerry: É porque a gente vive assim de bico, né? E não é sempre que tem bico para fazer. Aí sempre eu arrumo dinheiro e pergunto prá ela: Sandra tá faltando alguma coisa em casa? Aí eu tenho dinheiro, a gente vai no mercado e compro tudo que está faltando. Aí quando termina, que gastou todo o dinheiro, ela vem falar que está faltando isso... Aí tem que recorrer prá onde? Prá minha família. Aí eu fico bravo... Eu falo, eu tinha o dinheiro prá comprar 
tudo, levei você no supermercado prá nós fazer a compra, agora você tá me falando que tá faltando as coisas? Eu começo a ficar nervoso, a gente começa a discutir... E minha família, eu penso assim: a partir do momento que a gente assumiu a responsabilidade, a gente tem que ser digno e manter aquela família. Então a gente não tem que ficar pedindo. Porque se toda vez que faltar, a minha mãe for ajudar, eu vou ficar em casa sem fazer nada, só esperando cair do céu. Eu acho que não tá certo.

\section{$(\ldots)$}

(RV): Então vamos conhecer a Sandra, que está com 40 anos e diz: O Jerry não quer que a família saiba que nós passamos por dificuldades e fica bravo quando eu peço ajuda aos parentes. Sandra, por favor, entre. Tudo bem, Sandra?

Sandra: Tudo bem.

(RV): Você, no total, teve sete filhos?

Sandra: Sete filhos.

(RV): Um mora com vocês?

Sandra: Um mora comigo.

(RV): E os outros seis?

Sandra: Mora com a minha mãe e já tem casadas.

(RV): Já tem filhas grandes?

Sandra: Já.

(RV): E essas três que moram com a sua mãe, você ajuda?

Sandra: Não tem como eu ajudar, né? Porque meu marido faz bico, ganha pouco, né?

(RV): O Jerry? 
Sandra: É, ele não gosta que a minha mãe ajuda eu. E nem gosta que a família dele ajuda."

A platéia também participa da conversa. Ao final da apresentação de cada história, uma ou duas pessoas da platéia dizem o que pensam sobre um dos casos ou sobre o assunto em geral e, às vezes, fazem perguntas para os participantes. Depois de cada comentário, a apresentadora, em geral, abre espaço para que os participantes possam responder. Algumas vezes, a apresentadora dialoga com a pessoa que está comentando, identificando para quem ela está falando ou fazendo pequenos comentários.

Transcrevemos algumas participações do público comentando as histórias:

1) terceiro bloco: "Minha pergunta é para o terceiro caso. Você é linda, minha filha, você não merece esse marido que você tem. Prá que que você quer um marido desse que te bate, que te xinga, né? E ainda te trai. Você é linda, você tem um corpão, prá que é que você quer esse homem, filha, prá quê? E pro segundo caso, eu quero dizer (...) que mineirinho trabalha quieto, viu filha, se cuida... E pro primeiro caso, você é muito linda e seu marido não te merece porque ele sai final de semana sozinho e te deixa em casa. O que é que esse homem quer sozinho na rua, meu deus?"

2) segundo bloco: “Vocês dizem que é amigas, não é isso? Que tipo de amiga é essa que uma quer comer a outra? Procura viver a vida de vocês, gente... Vão trabalhar, olha outras vitrines, vai pro Brás, vai fazer alguma na vida... (Regina interrompe: O Brás é mesmo a mãe da gente...) Lá tem uma variedade de vitrines enorme... Vai viver a vida de cada uma porque já é tão difícil a gente viver a 
nossa, ainda vai querer viver a vida dos outros, vestir a roupa dos outros, calcinha, que é isso? Vai viver, gente. Ó, é bom viver"

3) primeiro bloco - A apresentadora pergunta para um homem da platéia: Você agüentaria uma situação dessas? Ele responde: “Não, não agüentaria, não. E eu acho que ela deveria repensar a situação aí porque é fraqueza, né? Ciúmes em excesso estraga e é sinal de fraqueza... Ele vai chegar uma hora que ele vai ficar sufocado, ele não vai agüentar... Ele mesmo vai sair fora disso aí..." RV: Tirar a camisa e sair andando pela rua? Platéia: “Vai, porque ninguém agüenta pressão o tempo todo, né? Muita pressão. Ela deveria ter mais segurança, né?"

5) primeiro bloco: “Eu acho que ele está certo porque no momento em que a gente fica pegando as coisas emprestadas, a gente vai se acomodando. Acaba o café, eu corro na vizinha. Amanhã eu nem vou me preocupar de comprar: a minha vizinha vai ter... E a sua mãe já toma conta dos netos, então, ela já tem um problema, já." A apresentadora interrompe e pergunta: Mas quando falta o dinheiro, porque pelo que eles disseram ou alguém ajuda ou então eles vão passar fome. "Mas eu acho que tem tanto jeito. Eu tive seis filhos e criei tudinho. Nunca fui na casa de vizinha pedir nada emprestado, não. Eu me virava, de um jeito ou de outro, mas eu me virava, porque emprestar incomoda muita gente"

$\mathrm{Na}$ semana acompanhada, somente na edição de 25/10/07, a platéia não participou do debate. Em compensação, ao final de cada história, foram apresentadas matérias com artistas de rua de diversas modalidades e estilos que falaram sobre seu trabalho e a importância da arte nas suas vidas.

A platéia recebe também ex-participantes do programa. A apresentadora, nestes momentos, aproveita para lembrar o fato 
e perguntar como está a situação no momento. No programa de 23/10/07, uma pessoa comentava os casos do dia quando a apresentadora pergunta: "Você participou de um programa nosso, qual era o tema mesmo?" A moça responde: "Quero minha mulher linda de novo". RV: "E continua lindona." "Com certeza, né? Agora não pode reclamar mais, né?"

Ao final do programa, um psicólogo comenta cada um dos casos e a posição dos protagonistas de cada história. Dois profissionais se revezam na função: Ildo Rosa da Fonseca e Anahy D'Amico. A apresentadora Regina Volpato também comenta o tema e algumas histórias, mas em sua fala sempre é enfatizada que aquela é apenas a sua visão. Em casos mais graves, ela aproveita para dar contatos de serviços de auxílio, como os telefones da Central de Atendimento à Mulher e da Primeira Delegacia de Defesa da Mulher, na edição de 22/10/07, em que algumas mulheres revelaram que apanhavam dos maridos.

Chamadas dos próximos temas e informações sobre programas antigos não são comuns, mas eventualmente aparecem. Na semana acompanhada, foi apresentado o caso de mãe e filha que participaram do tema "Você vive do passado" e que, segundo a matéria, passaram a conviver melhor depois do programa. O vídeo termina com as duas dançando, e a apresentadora explica que, na gravação do programa, a mãe tinha dançado (comportamento criticado pela filha), o que tinha feito a filha chorar e que eles, na edição, haviam suprimido o trecho em consideração ao estado que ela tinha ficado e que agora, vendo as duas dançando, estava emocionada: "é um presentão prá mim!".

O tema da gravação do programa também aparece no programa "Minha namorada não me deixa fazer nada", do dia 24/10/07. Na hora de conversar com o casal Marcos e Sandra, 
Regina lembra que na primeira data marcada a gravação não tinha sido feita porque Sandra, a namorada ciumenta, passou mal. O namorado esclarece que a pressão dela subiu porque a ex dele foi à sua casa levar a filha dos dois e ela ficou sabendo. Regina Volpato pergunta sobre como foi o atendimento médico no Ambulatório e como ela está agora antes de chamá-la ao palco.

\section{b. Conclusões}

O programa abre bastante espaço para que o público conte suas histórias pessoais e é, na televisão brasileira hoje, o maior espaço oferecido: uma hora diária de segunda a sexta-feira. Também é, dos casos estudos, o que trata de temas mais cotidianos.

Sob a ótica da mediação, tudo está sob controle da equipe do programa: o levantamento e a seleção dos temas, a escolha das histórias e dos personagens e a condução das narrativas através da entrevista feita pela apresentadora. As adequações em função do meio, como a edição para adaptar ao tempo de duração e às necessidades de imagem (disposição dos participantes no cenário, por exemplo), também acontecem sob controle da equipe profissional.

A seleção dos casos obedece aos critérios de noticiabilidade adotados pelo programa: histórias que representem o problema apresentado e que mexam com o público, emocionando ou fazendo com que reajam. 


\section{Viva SP - Comunidade Virtual}

O "Viva SP" (www.vivasp.com) surgiu como "SP 450", nas comemorações dos quatrocentos e cinqüenta anos da capital paulista. Entrou no ar em agosto de 2003, com a proposta de mostrar a visão e as relações que os moradores mantém com a cidade, como explica o criador da comunidade, Juliano Spyer ${ }^{154}$ :

"A proposta do site foi funcionar como uma alternativa para os espaços de convivência diários que estão desaparecendo. Curiosamente estamos mais perto uns dos outros nos prédios, mas os relacionamentos, os laços de solidariedade, o capital social - bem na linha de como a Jane Jacobs fala disso - vem se dissolvendo. o vivasp.com é uma comunidade para vizinhos online; passamos tempo *jogando conversa fora* nos nossos * portões virtuais*."

Já em seu surgimento, ele previu uma estratégia multimídia (ou multi-plataforma), associando o material veiculado online a boletins de rádio, como explica Juliano:

"ele foi criado no contexto do aniversário de 450 anos de $\mathrm{sp}$, primeiro porque eu estava voltando para a cidade e queria saber o que leva pessoas a viverem aqui, o que nos caracteriza enquanto paulistanos, e também porque a efeméride favorecia que o projeto fosse abraçado por um veículo de mídia tradicional e estabelecido, me dando a oportunidade de emplacar um case."

Os boletins são veiculados pela rádio Eldorado AM (700 $\mathrm{kHz}$ ) de segunda à sexta, às $5 \mathrm{~h} 20$ e às $13 \mathrm{~h} 45$ e aos sábados e domingos, às $6 \mathrm{~h} 20$, às $14 \mathrm{~h} 40$ e às $17 \mathrm{~h} 20$. Vários relatos são reprisados no programa "São Paulo de Todos os Tempos", do jornalista Geraldo Nunes (sábados, às $22 \mathrm{~h}$ e à meia-noite; e

\footnotetext{
${ }^{154}$ Entrevista concedida à autora desta tese por e-mail. Disponível no Anexo 8. Grifos do autor
} 
domingos, às $6 \mathrm{~h}$ e às 12 h). De 2003 a 2004, os boletins foram transmitidos também pela Rádio Eldorado FM $(92,9 \mathrm{MHz})$.

A participação na comunidade gerou atividades presenciais como sessões para contar histórias e visitas aos diversos bairros de São Paulo.

“E graças à integração contínua dos usuários assíduos, o projeto hoje conta com o apoio voluntário de 25 pessoas, que em conjunto pagam as despesas de manutenção do site, ajudam na administração do conteúdo e arrecadam dinheiro para atividades e passeios." (SPYER, 2007: 113)

Do início do projeto até os dias atuais, a quantidade de contribuições do público variou muito, de 10 a 200 relatos por mês, fora os comentários:

"esse conteúdo permitiu que o site sempre tivesse cinco textos novos na capa de segunda a sexta, desde que foi criado." (ANEXO 8)

Como as Comunidades Virtuais permitem o arquivamento dos textos, depois de quatro anos de funcionamento, - "Viva SP" atingiu a marca dos seis mil relatos publicados. (SPYER, 2007: 112)

Essas narrativas são enviadas pelo público através do próprio site do projeto. De lá, eles sofrem pequenos ajustes (correções gramaticais e ortográficas) que são feitas pelos responsáveis pela comunidade:

“...em termos editoriais, o regulamento do site é que o texto seja modificado o mínimo, apenas para que os relatos façam sentido para o leitor. A maior parte do trabalho consiste em limpar a formatação de html, fazer correções estéticas nos textos e editar e publicar as fotos." (ANEXO 8)

Mas as correções são realmente pequenas como se pode perceber na leitura dos textos publicados que, algumas vezes, trazem erros de digitação, pontuação ou mesmo gramaticais. 
Os textos são organizados em seis categorias: "No Centro - o coração da cidade"; "Minha São Paulo - comida, diversão e arte"; "Ângulos e paisagens - fotos e instantâneos da cidade"; "Nova terra, vida nova - emigrantes e imigrantes"; "Lendas Urbanas - a cidade e seus personagens"; e "Et Cetera - o que você quiser contar".

Dessas, "Minha São Paulo", é dividida em subcategorias: "Meu bairro, minha rua - histórias de casa e de amigos"; "Mesa paulistana - a comida da sua casa"; "Na carteira e no pátio histórias escolares"; "Na arquibancada - jogos, jogadas e jogadores"; "A cidade nas costas - seu trabalho e obrigações"; "Um dia de domingo - descanso, lazer, diversão"; "Visões de futuro - a cidade daqui a 10 anos".

Ao inserir sua contribuição, o público escolhe em qual categoria gostaria de ter seu relato inserido, além de informar o título, o resumo e o próprio texto em questão. Os campos autor, email e blog são de preenchimento opcional.

\section{a. Inserções analisadas}

Foram selecionados textos de várias categorias e subcategorias para compor a amostragem de análise deste trabalho. A preferência foi por histórias de caráter mais pessoal, que tivessem sido inseridas mais recentemente e que mostrassem a diversidade de temas e autores da comunidade.

1) "De como Jesus desceu da cruz", de Manoel Valente Barbas 26/10/2007 - "Meu bairro, minha rua - histórias de casa e de amigos", em "Minha São Paulo" http: //www. vivasp. com/texto. asp?tid $=6298 \&$ sid $=1$ 
2) "Baile de Formatura", de Maria Helena de Oliveira - 24/10/2007

- "Na carteira e no pátio - histórias escolares", em "Minha São Paulo" - http://www. vivasp.com/texto. asp?tid=6289\&sid=3

3) "O meu cachorrinho foi pra cadeia", de Udo Bock - 1ㅇ/11/2007 - "Nova terra, nova vida - emigrantes e imigrantes" http: // www. vivasp. com/texto. asp?tid $=6315 \&$ sid $=8$

4) "Valeu a pena prestar socorro?", de Wilma Romano 24/10/2007 - "Lendas Urbanas - a cidade e seus personagens" http: // www. vivasp. com/texto. asp?tid=6291\&sid=9

5) "Um alpendre da Avenida Paes de Barros", de Rebeca Gelse Rodrigues - 30/10/2007 - "Et Cetera - o que você quiser contar" http: //www. vivasp.com/texto. asp?tid $=6310 \&$ sid $=11$

O fio condutor de todas as narrativas é São Paulo que aparece como cenário e palco das histórias e memórias. Grande parte dos relatos encaminhados à comunidade é relacionada ao passado das famílias e da própria cidade e, neste sentido, o site da comunidade às vezes lembra um grande álbum de recordações, só que coletivo, fruto das memórias e depoimentos de diferentes personagens, de diferentes épocas. Os autores são todos personagens ou testemunhas das próprias narrativas.

Há passados mais longínquos ou mais próximos, é claro, mas são raros os exemplos de depoimentos ligados ao presente ele foram mais freqüentes no início do projeto. Atualmente, eles são disponibilizados em "Visões de futuro - a cidade daqui a 10 anos".

Como os textos são publicados quase exatamente como foram enviados, não há um estilo comum: vocabulários, estruturação de frases, ordem das narrativas, tudo muda de texto 
para texto. No caso dos autores que publicam mais de uma contribuição, é possível, inclusive, identificar o estilo próprio já desenvolvido (ou em desenvolvimento).

Para a identificação dessas diferenças de escrita, reproduzimos o primeiro parágrafo ${ }^{155}$ das contribuições selecionadas para análise:

1) "A minha filha mais moça chegou à adolescência sem religião. Faltava-Ihe essa disposição que existe nas pessoas para crer no sobrenatural, no mágico, no divino. Nessas alturas, já estava eu arrependido de não ter influído nesse ponto, na sua formação, pois via que esta crença faz falta, ajuda a levar a vida, a vencer obstáculos, impasses."

2) “Em um desses feriados prolongado recentemente, resolvi ver alguns álbuns de fotografias que tenho guardado.

São de viagens que fiz pelo Sul, Cidades Históricas de Minas Gerais e Rio de Janeiro, e é incrível como é importante as anotações abaixo das ou nas laterais das fotos, sempre marquei onde os lugares e detalhes que hoje vem a tona toda a emoção do lugar ou situação."

3) “Época da 2a Grande Guerra. Eu devia ter uns 5 ou 6 anos de idade e em casa só se falava em alemão, idioma de meus pais. Não nos falávamos na rua para evitar constrangimentos. 'Podemos ir pra cadeia', dizia mamãe."

4) “Estávamos no ano de 1986, sábado de carnaval. Animadas pelo lindo dia de sol, mamãe e eu decidimos ir à praia, passar os dias de folga no apartamento de minha sobrinha Argene, na Ilha Porchat e quem sabe até chegar ao Clube da Ilha apreciar os tradicionais

\footnotetext{
${ }^{155}$ Nessa reprodução, respeitamos totalmente as grafias e construções utilizadas pelos autores. No caso das narrativas de no 2 e 5 , selecionamos os dois primeiros parágrafos em função de serem bem curtos.
} 
bailes de carnaval que são realizados até hoje, com muita animação."

5) “Esta crônica é para falar de um pedacinho da cidade de São Paulo, um canto da zona leste, sito à Avenida Paes de Barros, no bairro da Mooca.

Relatarei sobre um 'alpendre' do conservatório onde estudei piano durante 9 anos de minha vida, que fica nessa avenida no número 166."

Não há na forma de iniciar a história, como podemos observar, uma padronização, diferindo de autor para autor, com uns anunciando sobre o que vão falar enquanto outros já começam na narrativa.

Há diferenças também na forma de condução, com autores enfatizando mais situações, diálogos e acontecimentos enquanto outros valorizam as impressões e sentimentos despertados. No primeiro grupo, podemos destacar as narrativas “O meu cachorrinho foi pra cadeia" e "Valeu a pena prestar socorro?", enquanto no segundo estão "De como Jesus desceu da cruz" e "Um alpendre da Avenida Paes de Barros". "Baile de Formatura" mistura as duas propostas.

Não há restrições por parte do site quanto ao tamanho das matérias, apenas quanto às fotos que devem ter formato JPG ou GIF e tamanho máximo de arquivo de 700 kb. Por isso, o tamanho dos textos também é tão distinto: nas edições analisadas variaram de 1.881 caracteres com espaços ("De como Jesus desceu da cruz") até 5.356 ("Um alpendre da Avenida Paes de Barros").

A formatação gráfica obedece a um padrão, com o nome da categoria (ou subcategoria) acima do título da narrativa. Na 
mesma linha do título aparecem: data e horário da inserção e o autor. Abaixo está o texto e ao seu final temos o e-mail do autor (quando foi disponibilizado), os comentários feitos e um link para mais histórias da mesma categoria.

Das cinco histórias analisadas, apenas uma optou por publicar também uma foto além do texto: em "O meu cachorrinho foi pra cadeia", há uma foto do autor sorridente ao lado do texto.

Embora haja categorias e subcategorias, a temática é livre e as histórias abordam aspectos bem distintos dos mesmos temas. São Paulo pode ser vista sob a ótica religiosa, humana, de seus espaços de convivência, etc. Em nossas matérias analisadas, os temas centrais foram:

1) A religiosidade descoberta numa peça encontrada nas ruas da cidade - em "Meu bairro, minha rua" - "Minha São Paulo"

2) O baile de formatura e o figurino da época - em "Na carteira e no pátio" - "Minha São Paulo"

3) A memória da Guerra e a perda do animal de estimação - em "Nova terra, vida nova"

4) O socorro a uma desconhecida - em "Lendas Urbanas"

5) A descoberta do amor à música, despertado pela avó - em “Et Cetera"

O tom adotado nas narrativas também difere de história para história: algumas têm um acento lírico (como "Um alpendre da Avenida Paes de Barros"), outras de humor (como "O meu cachorrinho foi pra cadeia"). Essa diversidade comprova que não há restrições do site ao estilo das contribuições. 
Embora a comunidade permita a inserção de textos de anônimos, a imensa maioria dos textos está assinada e os autores, inclusive, disponibilizam seus e-mails no fim da história.

A partir dessa identificação e dos comentários inseridos pelos leitores em cada narrativa, podemos perceber claramente a configuração de uma comunidade em que seus membros trocam entre si informações e estabelecem diálogos que, só quem faz parte desse grupo, pode entender completamente.

Para facilitar a percepção desta questão, reproduzimos os comentários publicados em cada história selecionada:

1) Número de comentários: 2

Nome: Miguel

Email:

\section{Comentário:}

Manoel, depois de ler teu texto que, diga-se de passagem, gostei muito, só posso tecer um comentário monossiláboco: Amém!

Nome: ana maria lisbôa mortari

\section{Email:}

\section{Comentário:}

Gostei muito, mas, discordo de você ter se achado culpado na época por ela não ter uma conduta religiosa ou outra qualquer, pois se não tivesse tido essa formação que de alguma forma lhe deu - talvez com exemplos de suas atitudes, que falam mais do que palavras - poderia ter pulado aquele Cristo, mas, sentiu-se tocada, recebeu-o como uma resposta e guardou-o... Só vemos respostas nas esquinas da vida, quando fomos e estamos preparados para ve-las ou senti-las... Hoje o editor estava inspirado na escolha dos textos!

2) Número de comentários: 3

Nome: Rose Gouveia

Email:

Comentário:

Menina, menina, Cadê as fotos? beijos

Nome: Nivaldo

Email:

Comentário:

Falou, falou, falou, e não exibiu nenhuma foto? Assim não vale.

Nome: Miguel 


\section{Email:}

\section{Comentário:}

Album de retratos e saudades combinam muito bem...

\section{3) Número de comentários: 3}

Nome: Miguel

Email: misagaxa@terra.com.br

\section{Comentário:}

Udo, à epoca do seu relato eu já existia e usufruia das artimanhas dos panos pretos colocados na janela para dar as minhas mamadas. No pós guerra, que eu vivi mais intensamente, tudo acontecia da mesma forma, apenas não tive nenhuima cadelinha presa...

Nome: ana maria lisbôa mortari

\section{Email:}

\section{Comentário:}

Gostei muito da história, bem escrita, gostosa de ler e além do mais revelando um hábito muito comum na época, quando para poupar os sentimentos das pessoas, principalmente crianças e idosos contavam "uma mintirinha que não fazia mal à ninguém..." falavam assim mesmo quando comentavam a história inventada... Mas, essa da sua avó foi sui generis...

Nome: Manoel Valente Barbas

Email: mvbarbas@terra.com.br

Comentário:

UDO bOCH: GOSTEI BASTANTE DA HISTÓRIA VERÍDICA, TÍPICA DE SÃO PAULO DE MINHA INFÂNCIA, DA 2a a GRANDE GUERRA, DOS "BLACKOUTS", DOS "É PROIBIDO FALAR EM IDIOMAS DO EIXO, DOS BONDES DE SANTO AMARO NA ESTRADA DE DORMENTES,EM LINHA RETA DE SE PERDER DE VISTA. DAS MENTIRAS DE QUANDO UMA PESSOA MORRIA, QUE TINHA IDO PARA O CÉU. A DO CACHORRO QUE FORA PARA A CADEIA POR FALAR EM ALEMÃO É HILÁRIA. GOSTEI!

4) Número de Comentários: 3

Nome: esther

\section{Email:}

\section{Comentário:}

Wilma, por essa e por outras é que a solidariedade está em baixa. Parabéns por sua atitude. Bjs.

Nome: Miguel

\section{Email:}

\section{Comentário:}

Foi realmente um gesto altriista e sem outras intenções a não ser a de ajudar. Por isso não te arrependestes. 
Nome: Nivaldo

Email:

\section{Comentário:}

Faz parte de sua índole, cara Wilma! Ajudar o próximo, sem olhar a quem.

5) Número de Comentários:

\section{Nome: Osnir \\ Email: \\ Comentário:}

1.o lembrei de minha neta Rebeca que nunca mais vi. Dizem que foi com a mãe e padrastopara S. J. dos Campos. E eu fiquei só com um fiozinho dela na memória. 2. quando eu ensinava datilografia uma das partes era o rítmo. É, em datilografia o rítmo também tinha sua importância. Parabens pelo texto. Volte sempre. Abraços.

Nome: Nivaldo

Email:

Comentário:

Sábia sua avó.

Nome: Miguel

Email: misagaxa@terra.com.br

\section{Comentário:}

Rebeca, linda estréia! Mas os aplausos, merecidamente, estou endereçando à sua vó uma pedagoga avançada para o seu tempo. Parabens e seja bem vinda.

Nome: esther

Email:

\section{Comentário:}

Olá Rebeca, seja bem vinda ao vivasp. Morei na Paes de Barros, ate' meus 20 e poucos anos e lembro-me do conservatório. Por acaso vc. seria parente do Didi ( só o conheci pelo apelido) que tocava violão divinamente?

Nome: Lidia

Email:

\section{Comentário:}

Bem vinda ao site, Rebeca. Linda sua crônica, que mais é uma lição de vida ministrada por sua avó através da neta aplicada. Escreva mais, deve ter muito o que contar.

Os comentários permitem dois campos de análise principal: um em relação a seu conteúdo e outro relacionado à sua autoria. 
No que se refere ao conteúdo, podemos verificar que comentaristas e autores já se conhecem e estabelecem, através da comunidade e sua proposta de publicação de narrativas, um diálogo.

$\mathrm{Na}$ história 1, por exemplo, Ana Maria Lisboa Mortari comenta que o editor estava inspirado na escolha dos textos naquela data, num claro sinal de que costuma acompanhar as publicações. Já na 2, Rose Gouveia se dirige à autora Maria Helena de Oliveira com um tratamento que indica a relação entre as duas. Diz ela: "Menina, menina, Cadê as fotos?". Na história 4, um comentário também indica a proximidade entre leitores e autores: Nivaldo diz "Faz parte de sua índole, cara Wilma!". Mas é na história 5 que mais percebemos a formação do grupo e a participação dialógica: dos cinco leitores que publicam comentários, quatro escrevem textos de saudação pela sua "estréia" no Viva SP demonstrando que já conhecem todos os autores.

$\mathrm{Na}$ questão da autoria, percebemos que os comentaristas costumam se repetir de uma história para outra: os 16 comentários mapeados foram postados por 8 leitores, sendo que o que mais publicou, comentou todas as cinco histórias, enquanto quatro deles comentaram apenas uma história analisada. Pode-se perceber também que os comentaristas são autores de outros textos e um deles (Manoel) inclusive é autor de uma das nossas histórias selecionadas.

\section{b. Conclusões}

A comunidade virtual "Viva SP" difere dos casos analisados anteriormente já no que se refere à seleção que 
praticamente inexiste. Ela apenas acontece no caso de textos que fogem totalmente à proposta.

Também a condução das narrativas está a cargo do público. Ao editor cabe apenas o trabalho de limpar os textos dos códigos pré-estabelecidos, a fim de deixá-los com a mesma apresentação gráfica. São realizadas ainda pequenas correções de estilo.

O formato não traz grandes restrições, permitindo a publicação de materiais de diferentes tamanhos e estilos. Mas há restrições quanto a arquivos que não sejam de texto ou de imagem estática. 


\section{Puzzle Diário - Blog}

O blog "Puzzle Diário" foi criado em 2.003 e faz parte do Blogger- http://puzzlediario.blogspot.com/. Sua autora, Lucia Freitas se define assim no perfil disponibilizado no blog: "mulher, jornalista, aprendiz de feiticeira".

Ela é membro do Blogger desde 2.001 e é conhecida na blogosfera brasileira principalmente por outro diário seu, o "Ladybug Brasil" que, segundo ela, fala de:

"movimentos, ferramentas, tendências e novidades que brotam todos os dias em todos os cantos desta gigantesca teia chamada world wide web" $^{\text {"156 }}$

Mas sua participação não pára aí: ela assina ainda o Blog "Jardim dos Narcisos" (http://jardimnarcisos. blogspot.com/) que segundo ela foi criado com o fim de um amor e participa dos coletivos: "Goitacá" (blog sobre viagem http://www.goitaca.com/), "Desabafo de Mãe" (sobre maternidade e educação - http://www.desabafodemae.com.br/), "Faça a sua parte" (ecológico - http://facaasuaparte.blogspot.com/), e "Nossa opinião" (opiniões sobre assuntos diversos http://www.nossaopiniao.com.br/).

Já o "Puzzle" é definido como um diário de viagem interior:

"O Puzzle Diário nasceu para funcionar como um mapa digital dos movimentos da vida em mim. Resultado do meu processo de estudo de Anatomia Emocional, com Regina Favre, é atravessado por este

\footnotetext{
${ }^{156}$ Disponível em http://www.ladybugbrazil.com/about/. Acesso em 1ㅇ11/07.
} 
conhecimento e minha insatisfação com o jornalismo que encontrava nas redações."157

No topo da página do blog, embaixo do título, está: “A vida é um imenso quebra-cabeças, que se rearranja ao sabor dos encontros, das emoções, dos afetos e das intensidades."

Com uma abordagem mais intimista, o blog aborda temáticas variadas, de acordo com as preferências de Lúcia:

"Publico o que me toca, temas que acredito serem interessantes para 'terceiros'. No Puzzle, o registro é meu, partilhado com amigos mais próximos. Os temas de que gosto (saúde, ecologia, proteção animal, crescimento do humano, linguagem e metalinguagem, literatura e cinema, entre outros). Não há temas/assuntos proibidos. A única proibição é atacar terceiros - mas, confesso, já falei bem mal de um exnamorado (sem citar o nome) (...) o critério do Puzzle permanece: falo do que experimentei ou do que me toca. A proibição é idêntica. Se não gosto, não falo."

O blog permite a inserção de comentários que, no entanto, não são numerosos. Seu caráter é tão pessoal quanto os dos posts do blog:

“Os comentários do Puzzle são pessoalíssimos. Amigos comentando movimentos, em geral, novos conhecidos que vêm visitar e deixam registro."

Mas Lúcia diz que não usa os comentários como pauta para outros posts. Segundo ela, os assuntos abordados surgem mais de conversas em grupos de discussão.

O modelo de blog adotado não limita as opções da autora: os posts podem ter o tamanho que ela desejar e também são permitidos arquivos de imagens, vídeos ou áudio:

"Acho que isso é resultado do domínio de HTML, PHP e outras linguagens de programação que me permitem instalar e desinstalar ferramentas e buscar novas formas de interagir."

${ }^{157}$ Entrevista concedida pela blogueira Lucia Freitas por e-mail à autora desta tese. Disponível em Anexo 9. 
As postagens não são freqüentes, em geral, uma por semana. Nunca mais de uma por dia. A página de abertura do blog em outubro de 2007 trazia posts a partir de junho do mesmo ano (não o mês inteiro, apenas a sua segunda metade). Os anteriores estão em arquivo disponível para ser acessado no lado direito da página, sob o sugestivo nome de "Já aconteceu".

\section{a. Posts analisados}

A seleção dos posts analisados foi feita levando em conta a página de abertura em outubro de 2007 (posts de junho a outubro). Optamos por um post de cada mês e buscamos exemplos que tratassem de assuntos diferentes entre si. No entanto, como os posts são, em geral, bem curtos e também em virtude da existência de referências cruzadas entre eles, a fim de permitir o estabelecimento de comparação adequada frente aos casos das outras mídias, faremos também a análise geral do material publicado ainda que o foco central sejam os cinco posts escolhidos:

1) “Da exaustão" - 21/10/07 - 9:24 pm

2) "Sobre enganos, doçura e vida" - 18/09/07 - 12:30 am

3) "A morte" - 15/08/07 - 6:57 pm

4) "A viagem da mala sem alça - para o além" - 02/07/07 24/08/07 - 9:26 pm

5) "Perdoa a tua igreja, senhor. Ela não sabe o que faz" - 30/06/07 - 7:48 pm

Como característica do formato blog, os posts são disponibilizados na página por ordem cronológica inversa de postagem, sempre com os mais recentes na parte superior, empurrando os mais antigos para baixo ou para as páginas de arquivo. 
Como padrão, temos a data no formato mês, dia e ano, acima do título do post em destaque (fonte maior e em outra cor), o texto, e então as informações de quem postou (no caso como se trata de um blog individual, só há uma autora), o horário da postagem e os comentários. Há também a possibilidade de enviar o material por e-mail a quem se desejar.

Embora, segundo a entrevista de Lucia Freitas, o formato não limite o tipo de arquivo disponibilizado, são poucos os arquivos não textuais na página do blog. Nos 30 posts na página principal, além de textos são encontrados apenas fotos e ilustrações (ainda assim em pequeno número: 16) e um game para ser jogado na própria página. Das ilustrações/fotos, apenas uma é o post em si; duas vem acompanhadas de um texto-legenda e 13 estão junto com um texto maior.

O único arquivo interativo é justamente um Quebracabeça de cores que o usuário tem que resolver num número máximo de jogadas. Não há rankeamento dos resultados, nem limite de partidas por usuário.

No entanto, nas páginas de arquivo realmente é possível encontrar vídeos e áudios, em alguns meses com maior freqüência e em outros quase ausentes.

Cada post, seja de texto ou de imagem, recebe um ou mais marcadores de classificação por tema, o que permite que os usuários possam consultar apenas inserções de um único assunto. No "Puzzle Diário", os marcadores são: 2007, adoção, boa notícia, defesa animal, família, formatividade, fotografia, humor, pessoal e poesia. É na categoria pessoal que são classificados a maioria dos posts. É a própria autora que define os marcadores e a classificação de cada post. 
Dos cinco posts analisados, três tinham apenas um marcador e dois se inseriam em duas temáticas. Todos os cinco apresentavam marcadores para a temática Pessoal e os dois que traziam mais um marcador remetiam a 2007. Como foram justamente os mais antigos que apresentam essa marca (meses de junho e julho) e os demais também foram postados em 2007, apreende-se que a autora deixou de classificá-los por data a partir de agosto.

O público pode também consultar os arquivos por data, em “Já Aconteceu”. A opção, neste caso, é por mês e ano, desde março de 2005. Pelo arquivo, podemos notar que o mês em que mais foram produzidas inserções foi junho de 2007 (17 posts), seguido de março do mesmo ano (14 posts). A autora alterna muito a atualização do Blog, passando, em alguns períodos, vários dias sem blogar. O mês de maior ausência foi agosto de 2005, quando ela inseriu apenas dois posts. No primeiro do mês, initulado “Preguiça triste", de 16 de agosto de 2005, explicava a ausência:

"Faz falta o grupo. Sem os anatômicos quase perco o gás.

Tá duro viver, seguir em frente. Um silêncio enorme me enche, preenche.

E o blog vai sofrendo de falta de notícias.

Enquanto no mundo lá fora o fluxo se mantém, intenso, constante." (PUZZLE DIÁRIO)

Dois dias depois (18 de agosto de 2005), completava em “(Quase) ninguém se salva”:

“Gente! Não liguei o computador o dia todo. São $22 \mathrm{~h} 30$ e me atrevo a entrar para ver se havia alguma mensagem interessante. 59 e-mails me aguardavam no servidor. Destes, somente 51 chegaram à minha caixa postal ( 8 spams imediatamente exterminados pelo Thunderbird). Dos 51 restantes, nenhum interessava.

Ninguém merece! Não havia nenhuma informação interessante para matérias. Só informações irrelevantes, mais xingamentos ao governo. Restou um 
único, mas este foi de ontem: o e-mail da Amanda

bendizendo os amigos. E só!!!" (PUZZLE DIÁRIO)

O post mostra que a autora utiliza o material que recebe eletronicamente (por e-mail) para definir pautas e levantar assuntos sobre o que falar.

Embora o "Puzzle" permita a participação do público em comentários, o recurso é pouco utilizado pelos visitantes. Dos 30 posts disponíveis na página, apenas seis geraram comentários, sendo que o mais comentado ("Amanhece, perdão!", de 08/10/07) levou a cinco participações, uma delas da própria dona do blog, travando um diálogo com uma das comentaristas. Reproduzimos abaixo os comentários inseridos nesse post:

"O Profeta disse...

Há um espaço aberto

Estas pedras guardam segredos do tempo

Aromas dispersos invadem-me a lembrança

Este mar tem as cores do perdido sentimento

Bom fim de semana

Doce beijo

5: 49 PM

drang48@gmail.com disse...

menina, a dor da separação não nos impede de tentar de novo, não é. Sempre tentando ser feliz. Mas nunca esquecendo de que a felicidade não está no outro, mas em nós mesmos.

Vou ao BarCamp. Vamos nos conhecer, certo?

abraço, menina

\section{1:39 AM}

Lucia Freitas disse...

Denise, queridona...

Desistir jamais. Estou aqui pra ser feliz - e, se puder, melhorar um pouco o planetinha azul. Ah, que droga! eu não poderei ir ao BarCamp (apesar de ainda estar inscrita). Tenho um compromisso 
profissional o fim de semana todo : (

bj

1:24 AM

Leo Lama disse...

Ah, as jornalistas também perdoam...

2:00 AM

Aichego disse...

Oi Lucia.

Obrigada pela visita.

retribui e gostei!

Beijocas,

Barbs!

4:01 PM

Os internautas que deixam seus comentários são identificados pelo username que utilizam no Blogger (quando associados) ou pelo e-mail disponibilizado na página de inserção de comentários. Como a autora utiliza a modalidade de comentários moderados, eles só ficam disponíveis na página depois de aprovados pela blogueira.

Não há uma repetição freqüente dos autores dos comentários.

O público pode enviar o post lido para quem desejar através de um sistema de envio disponível no blog, bastando informar seu nome, seu e-mail e o e-mail de a quem se deseja enviar. É possível ainda encaminhar uma mensagem ao destinatário junto com o post escolhido.

Os assuntos abordados são variados, remetendo às experiências vividas, impressões, sentimentos, ou seja, um "mapa digital dos movimentos da vida em mim" como definiu a autora. Tudo num clima bem intimista. 
Nos posts analisados, todos classificados pela autora na categoria "Pessoal", encontramos a seguinte temática:

1) o acúmulo de atividades

2) a esperança diante da vida

3) a perda de um familiar

4) o fim de um relacionamento

5) a relação com a Igreja e a religiosidade

Não há, na construção do blog a preocupação de documentar todos os acontecimentos da vida da autora e sim de registrar suas impressões frente a fatos e situações em geral cotidianas: o acúmulo de atividades e a falta de tempo no mundo contemporâneo, a morte, os relacionamentos afetivos, entre tantos outros.

Às vezes, os posts fazem referências a pessoas que fazem parte da vida da blogueira, quer sejam citados nominalmente ou não. Assim, na entrada "Sobre enganos, doçura e vida", de 18 de setembro, ela faz referências a amigos (Zélia e Danilo) e projetos dos quais participou sem explicar ao público que não a conhece, quem são eles. Há apenas links para sites (o blog do Danilo e o site da MAC) através dos quais, os internautas podem buscar informações para compreender totalmente o texto e, assim, ter mais informações sobre a autora.

Já em "A morte", de 15 de agosto, aparecem a Tia Marilena, o tio, a mãe, os primos, estes sem a citação dos nomes. A ausência do nome do personagem marca também "A viagem da mala sem alça - para o além", de 2 de julho, em que fala do fim de um relacionamento. No entanto, o texto remete a outro post, de 16 de fevereiro, que traz mais informações sobre a história ("A pena que me dá é que eu admirava este homem - quase tirei do ar o post em 
que falava dele, no dia 16 de fevereiro. Não vou fazer isso, não. Vou me respeitar - já que ele não foi capaz - e manter tudo o que senti vivo.", diz ela). Assim, ao dar a informação sobre a existência do outro post, ela permite que o leitor mais curioso possa recuperar a história e no arquivo ler na entrada intitulada "Não te conheço?":

"Tudo isso para deixar claro que estou encantada por um cara que conheci na internet. Ele não tem a menor idéia disso, tenho quase certeza que jamais notou minha 'presença'. E a cada dia que passa, me vejo mais derretida. Suas fotos são geniais, o cara escreve textos sensacionais, manda dicas pra lá de bacanas na lista em que o conheci... visito o seu flickr - às vezes até deixo recadinhos mas não declaro interesse -, leio os textos nos blogs (ele também tem muitos), escuto seus podcasts. Já sei que ele também gosta de gatos (tem dois).

Observo tudo, teoricamente coberta de anonimato, e fico na minha. Digo teoricamente porque sei que ele pode descobrir quem eu sou (na internet, como na vida aqui fora, privacidade e anonimato são uma falácia). Mas porque tentaria?

Suspiro.

Vou trabalhar que ganho mais. Mas que este homem parece ser um pedaço de mau caminho, ah, isso ele parece. Estou curiosa."

Acompanhar o desenrolar da história não é difícil e no dia seguinte à primeira referência, lê-se no post "Violets for yours furs" (17/02/07):

"Só disse o que realmente sinto a respeito do assunto e do site em questão (não, eu não vou citar). Resultado: o moçoilo que me interessava ficou feliz, feliz. Convidou pra um drinque. (vocês estão vendo o sorrisinho aqui? Imaginem, imaginem)

Mais do que rápido topei. Na velocidade da luz, liguei. Fiz bem - muito bem. Ao vivo, o que senti navegando se confirmou: é um homem maravilhoso, mesmo. Intuição virtual? Rá! Foi de verdade mesmo.

E agora, como diz a Marga linda, segue a vida, começam os disparos, vislumbres de outros mundos. Agora começa este cruzamento único que o amor traz: sorrir pro dia lindo que amanheceu, pra briga dos gatos, pra dor que toma conta quando o moço da uma sumidinha..." 
O tamanho das entradas também é variável e não segue um padrão: textos equivalentes a uma legenda convivem com longas histórias, de acordo com o que foi desejado pela autora.

Em comum, o estilo do texto marcado por uma redação intimista, numa linguagem informal e recheada de referências a pessoas que não são apresentadas no site. Selecionamos trechos ${ }^{158}$ dos posts analisados que mostram claramente essas características:

1) "ando exausta, mas não paro, não descanso. compromissos, amigos, compromissos. o mundo chama e não há como 'ostrar' (ficar quietinha no meu cantinho). (...) A experiência de hoje foi algo único. Na tentativa de me conter - a boca repetia, baixinho, conceitos durante a aula, surgiram gases. Ai, que vergonha. Veio a imagem, antiga, de uma aula do Corporificando, quando eu aprendi que algumas das minhas expressões eram puro 'desperdício' de excitação que poderia me fazer crescer. De novo, molhei os olhos. A tristeza, velha companheira, deu um alívio. (...) Pequenos elementos brotam do fim de semana intenso. Preparação para a semana, cheia de trabalho, pontilhada por esforços que vão além de mim. O melhor é que tudo resulta em satisfação."

2) "De novo mergulho abaixo do limite. Outra vez sei que a superfície está mais perto. Não tenho mais medo. Apesar de ter me prometido (através da Zélia) não me enganar mais, sei que vou errar, sim. que bom! Desde que o erro traga sua lição, será ótimo! (...) Saber que a vida - e a mudança - tem sim um trecho de amargor. Lembrar que, sim, podaram a amoreira onde eu costumava roubar doçura no sol a pino e na noite alta. Mas há

${ }^{158}$ Nas reproduções foram respeitadas a grafia e pontuações originais dos textos. 
outras, sempre haverá. E sempre, sempre, sempre, este vagalume chamado esperança, que pisca em frente aos meus olhos."

3) “Mais um deixa o convívio. Aliás, uma. Tia meio distante, com quem tive pouco contato. Mas sou fã dos primos (também distantes, também pouco contato). Enfins, coisas que fazem parte da vida. O enterro acontece amanhã cedo, em Santos. Não faz dois anos enterramos o marido dela, meu tio, no mesmo cemitério. Até têm um certo encanto as histórias de casais que não sobrevivem à morte. Chamam à cena o velho amor romântico, que já morreu mas ainda não foi enterrado.(...) A meu lado, a dor da minha mãe - eu imagino, pela amiga, pela contra-parente, pela família que já não é mais dela. Coisas do contemporâneo: a minha mãe não faz mais parte daquela família. Ver pulsos e impulsos nos vivos da família - as hesitações, a espera sem velório, não saber o que fazer sem o ritual, as primas, o primo que agora ficou órfão de pai e mãe. Lembrei do tio, em outra mesa de aço. Amanhã a esta hora, os dois peregrinos vão estar de novo lado a lado."

4) “Eu queria me divertir - sexo, risada, boa conversa - e só. Ele inventou de complicar - muito. Começou manso, com a velha sedução (deliciosa) de que os homens são capazes. Adoro ser seduzida, confesso. A coisa estava boa, me deixei levar. (...) Venci as reservas, deixei de lado a cautela e entrei de cabeça. Dei com o coco num embroglio horroroso: um homem indeciso, fraco, mentiroso. Nada verdadeiro. Que inventa mil histórias (dignas de boa ficção científica) para tentar não enfrentar decisões... Pena que não vi antes. (...) Sem esta mala sem alça, carregada de pedras, a vida deslanchou. Ontem o dia foi difícil, mas bom. Hoje o dia foi melhor. $E$, tenho certeza, já já aparece alguém que me toque o coração de novo. Ah, canalhas também são ótimos professores. Nos ensinam direitinho como consertar corações partidos e seguir 
em frente. Adorei a viagem. Já estou planejando a próxima. Algum candidato?"

5) “Esclareço que fui criada católica e, nos últimos anos, desenvolvi uma particularidade enorme: vou à igreja quando me dá na telha para rezar do meu jeito. Não suporto o papa e me declarei autoexcomungada no instante em que ele foi anunciado. Me vejo em várias saias justas por conta desta história.(...) Por essas e outras, fazia muito tempo que não ia à igreja. Hoje compareci à missa de sétimo dia de um conhecido. Cheguei cedo, rezei o terço junto com o povo antes da missa - feliz e contente, registro. Tive vários insights, me emocionei, lembrei da minha avó Esther (que adorava aquela igreja), perdoei um ser humano que andou brincando com o meu coração. (...) O negócio pegou no instante em que o folheto falou mal dos judeus e piorou quando no sermão o padre disse que os outros cristãos não são cristãos de verdade. Dei o troco na reza seguinte. Em vez de dizer revive a tua igreja, senhor, pedi em voz bem alta: perdoa a tua igreja, senhor. Aproveitei e reforcei a distribuição de perdão - principalmente praquele cara que deixou o meu coração partido. Sabe que parece que consertou?"

\section{b. Conclusões}

No blog "Puzzle Diário" todas as etapas da mediação humana estão nas mãos da própria autora. É ela que seleciona quais fatos, quando e de que forma narrar.

Os critérios de seleção informados por ela confirmam a preocupação de publicar aquilo que desperte o interesse do público, ainda que a escolha seja feita dentro do conjunto de questões e impressões pessoais do seu cotidiano. 
Toda a condução das narrativas está a cargo dela que é a protagonista das histórias. A ela cabe decidir o que usar nas narrativas (textos, imagens e/ou outros arquivos), qual o tamanho e o estilo dos textos.

Há uma padronização de títulos e disposição de informações (data das postagens, comentários, marcadores) mas que não representam limitações às possibilidades de narrativas.

O público pode participar e a autora, inclusive, costuma travar diálogos com ele nos espaços de comentários. No entanto, como esse recurso é mediado, apenas os comentários aprovados por ela são publicados. 


\section{CONCLUSÕES}

“A pessoa não é um produto acabado, mas uma criatura aberta pela ambigüidade e enriquecida pelo desejo. Não constituímos um ser definido, mas perambulamos entre a necessidade de plenitude e a busca de sentido." (Castor Bartolomé Ruiz. Os Paradoxos do I maginário) 
O propósito desta Tese foi analisar como os meios de comunicação trabalham com as narrativas de histórias pessoais de seu próprio público, avaliando os espaços destinados e o tipo de mediação empreendida pelos meios.

O tema mostrou-se extremamente atual, com a crescente busca de espaços para expressão por parte do público associada ao interesse dos meios de comunicação por temas do cotidiano e pela valorização do homem comum.

$\mathrm{Na}$ verdade, pudemos comprovar que o desejo do ser humano de ter suas vivências registradas e, com isto, sua existência validada, acompanha a própria história da humanidade ainda que se credite à Modernidade a estruturação do mundo a partir dos seres humanos.

Paralelamente, o desenvolvimento dos meios de comunicação e sua estruturação como um sistema permitiu o estabelecimento de interfaces com todos os setores da sociedade contemporânea, caracterizando uma sociedade media centered.

Apoiamos nossa interpretação fundamentalmente nos trabalhos demonstrando que as mudanças empreendidas nas esferas pública e privada alçaram os meios de comunicação à função de praça pública por onde passam os debates das principais questões da sociedade.

Com essa nova configuração posicionando as mídias no cruzamento de muitas vias e, inclusive, transferindo ao sistema midiático funções antes delegadas às instituições públicas, propaga-se o entendimento de que as coisas de fato só acontecem quando são veiculadas pelos meios de comunicação. É a idéia do "acontecimento midiatizado". 
Também as histórias de vida humanas buscarão nos meios de comunicação a sua validação. Através dos espaços para o relato dessas experiências, o público terá suas necessidades de registro, divulgação, entendimento e perenização atendidas. E a resposta dos meios de comunicação a este pleito irá diferir de mídia para mídia e ao longo do tempo.

Nossas hipóteses principais foram:

I - Os espaços oferecidos para os relatos de histórias pessoais variam de mídia para mídia, no entanto, os critérios de seleção adotados pelos diversos meios de comunicação são praticamente comuns e reproduzem os critérios de noticiabilidade jornalística (interesse e adequação da história ao público do veículo).

II - A expansão das Novas Tecnologias da Comunicação ofereceram a possibilidade do público desenvolver mais livremente o papel de autores e o crescimento deste tipo de experiência influenciou diretamente os demais meios, forçando-os a também criarem novos espaços (e ampliarem os já existentes) para este tipo de comunicação. Essa readequação é parte inerente à configuração do Sistema Midiático contemporâneo.

Ambas foram plenamente comprovadas durante este estudo. Em primeiro lugar, o mapeamento dos espaços que os meios de comunicação oferecem para o relato das histórias pessoais indicou que cada meio de comunicação procurou, com maior ou menor intensidade, de acordo com as características de cada veículo, desenvolver essas áreas. Estas diferenças aparecem tanto na análise de mídia a mídia quanto historicamente, dentro de um mesmo meio de comunicação.

A avaliação permitiu ainda comprovar que é a partir do desenvolvimento das Novas Tecnologias de Comunicação que todos os meios irão reforçar a aposta neste tipo de espaço ou trabalhar a 
valorização dos existentes. Esta percepção fica mais clara a partir do enfoque histórico destes espaços e também da avaliação feita no momento atual de cada mídia.

A avaliação do momento atual associada aos estudos de caso comprova também os critérios de seleção das histórias a serem divulgadas como comuns aos vários meios e intrinsecamente ligados aos critérios de noticiabilidade praticados por aquele veículo. Nos estudos de caso, isto fica claro não só nas entrevistas com os responsáveis por cada programa/quadro/seção, mas também no próprio levantamento dos temas de cada edição analisada.

$\mathrm{Na}$ análise de cada meio de comunicação separadamente, tínhamos as seguintes hipóteses:

a) Mídia Impressa: é das que mais limitaram os espaços destinados aos relatos pessoais do público. Entre as publicações, são as revistas femininas as que sistematicamente têm desenvolvido esses espaços. O grau de mediação humana é muito grande, transformando o relato inicial de forma a adequá-lo à linguagem e ao estilo da publicação.

b) Mídia Eletrônica:

b.1) O rádio buscou ampliar esses espaços por conta de sua característica interativa e sua baixa complexidade técnica e quanto mais popular é a emissora, maiores são estes espaços. A mediação permanece mesmo quando a participação/relato é ao vivo. No entanto, é quando os relatos são recebidos previamente que essa mediação se dá de maneira mais forte e com mais recursos técnicos (utilização dos elementos constituintes da linguagem 
radiofônica: a música, a palavra, os efeitos sonoros e o silêncio) .

b.2) A televisão, em função de sua complexidade técnica, limitou esses espaços até muito recentemente. Hoje, com o aumento das participações ao vivo e o crescente interesse por temas comportamentais, esses espaços estão maiores. Tal qual o Rádio, quando os relatos não são feitos ao vivo é que a mediação tecnológica mais se destaca.

c) Mídia Digital: os aspectos que marcaram o surgimento da Internet (multidirecionalidade e ausência de centro) determinaram a ampliação das possibilidades de participação do público e a diminuição do papel de mediação dos profissionais de comunicação sobre esses relatos. A mediação, neste caso, é quase totalmente tecnológica e o papel do profissional de comunicação é mais o de um moderador.

Ao longo do desenvolvimento deste trabalho, todas essas hipóteses foram totalmente confirmadas.

A limitação imposta pela Mídia Impressa ficou patente até mesmo na dificuldade de selecionar os casos a serem estudados, fazendo com que nossa escolha recaísse duplamente em revistas femininas, frente à ausência desses espaços nos demais tipos de veículos.

Particularmente no caso dos jornais esta situação é mais complicada. Pela amostragem acompanhada, pudemos verificar que falta aos jornais a sensibilidade de permitir ao público, ele também, contar boas histórias, bem como o senso de oportunidade de permitir que a conversa iniciada por leitores na seção de cartas cresça e ocupe outros espaços nos jornais. 
O fato que mais representa simbolicamente esta situação é a percepção de que um dos espaços mais consistentes para o público escrever sua história nos jornais está na coluna "Bichos" da "Revista da Folha"' (suplemento da Folha de S. Paulo de domingo).

Nos demais veículos, os espaços principais estão mesmo nas revistas femininas. No entanto, o controle sobre o que e como publicar está totalmente na mão dos produtores do veículo. $\mathrm{Na}$ etapa de seleção, inclusive, algumas histórias são buscadas pela equipe porque o tema interessa ao veículo e não enviadas espontaneamente pelo público. A narrativa também sofre diversas adequações (de estilo, tamanho e mesmo de conteúdo, com inclusão de detalhes e retirada de outros da narrativa original) procedidas pela equipe e fora do controle do próprio autor. São praticadas ainda adequações pertinentes ao meio, como enquadramento no projeto gráfico do veículo e inclusão de outros elementos (fotos, ilustrações) que não os enviados originalmente.

Já o rádio é, entre os meios tradicionais pesquisados, o que mais abre espaços para este tipo de comunicação. Surpreende, inclusive, o número de espaços destinados às participações ao vivo que incluem tempo para que os ouvintes relatem ou discutam experiências de outros ouvintes a partir de suas próprias vivências.

No entanto, é importante ressaltar que este tipo de programa/quadro é característica das chamadas rádios populares, não sendo reproduzido nas demais emissoras.

Nas emissoras jornalísticas, a participação dos ouvintes se dá principalmente com opiniões e comentários sobre assuntos da pauta dos programas. Também são abertos espaços para envio de reclamações em relação a serviços públicos e empresas, num modelo muito parecido com que é praticado pelas Seções de 
Defesa do Consumidor dos jornais impressos. Como as matérias veiculadas são cada vez mais factuais, raramente são encontradas narrativas de vida de personagens de reportagens. No que se refere ao Jornalismo Colaborativo, a participação do público é, em geral, ligada a informações sobre o trânsito.

Comparando AMs e FMs, são as primeiras que oferecem participações mais longas e onde é comum o público falar de suas histórias, problemas etc. Nas FMs, a vocação musical limita esses espaços e reforça as propostas de participação vinculada a pedidos musicais e games.

Mas as narrativas no rádio, a exemplo do que ocorre nas revistas femininas, ocorrem sob o total controle do emissor, que as seleciona e reconstrói fazendo adaptações tanto de estilo quanto às pertinentes ao meio radiofônico (inclusão de sonoplastia, por exemplo). Entre os casos estudados, o de rádio foi o que, pela primeira vez, indicou a necessidade de atender ao público que deseja ver sua história exposta no meio de comunicação como o critério principal para a veiculação.

Quando o relato ocorre ao vivo, a mediação se dá com o apresentador conduzindo a entrevista, interrompendo a narrativa para buscar outras informações ou para detalhar trechos.

É na televisão que os efeitos das Novas Tecnologias da Comunicação sobre o sistema mediático podem ser melhor observados: coincidindo com a abertura da internet para o grande público, é nos anos 90 que a TV irá desenvolver mais variados espaços para as histórias pessoais do homem comum em contraposição à experiências isoladas que vinham sendo desenvolvidas até então.

Mesmo assim, os espaços ainda são restritos e as narrativas sofrem forte mediação não só humana, mas também 
tecnológica com adequações ao tempo e à linguagem específica do meio televisivo.

Nas Mídias Digitais, a mediação varia de muito leve até inexistente e, pela primeira vez, encontramos exemplos do público que se torna autor da própria história (blogs), selecionando o que quer divulgar de suas experiências, em que momento e de que forma. Há a percepção clara de buscar publicar coisas de interesse do público. Ele passa a ser seu próprio editor. A mediação que ocorre ali é puramente tecnológica, inclusive entre o autor e o seu público.

Quando a mediação humana existe (comunidades virtuais), ela se dá de maneira tênue, influindo de maneira diferenciada em relação aos demais meios, nos processos de seleção (que em algumas experiências ficam a critério do coletivo de leitores/usuários e, em outras, mas mãos de um editor que, entretanto, procura mais organizar as informações que, de fato, selecioná-las). A exemplo do rádio, o caso estudado em comunidade virtual também apontou a necessidade de oferecer espaços para sua expressão (ainda que com o objetivo de aproximar pessoas e gerar laços) como critério para publicar a história. No caso estudado, inclusive, não há seleção do material enviado em função do interesse que possa vir ou não despertar no público.

No desenvolvimento da pesquisa (bibliográfica e de campo), algumas questões revestiram-se de maior importância e merecem ser discutidas separadamente da questão da comprovação das hipóteses da tese.

Em primeiro lugar, a partir dos levantamentos para desenvolvimento da abordagem histórica pudemos notar que há muito pouco escrito ou publicado sobre histórias pessoais, 
participação do público e menos ainda sobre narrativas de autoria do próprio público veiculadas nos meios de comunicação. A história da mídia é contada ainda fortemente sob a ótica dos meios e a questão do público que se constitui como autor ainda é muito pouco explorada fora dos debates sobre as Novas Tecnologias da Comunicação.

No entanto, o debate desta questão e sua documentação revestem-se de importância maior a partir da nova configuração estabelecida no sistema midiático com a inclusão das mídias digitais e será fundamental para o entendimento dos papéis dos profissionais de comunicação em geral e dos jornalistas em particular na atuação dentro dos novos ambientes comunicacionais.

Os resultados da pesquisa de campo empreendida demonstram, em particular a partir dos estudos de caso, que mídia e mediação possuem uma relação intrínseca, sendo que nas mídias tradicionais (impressa ou eletrônica) essa mediação quase sempre aparecerá como fator obrigatório. O grau dessa mediação é determinado não só pelo tipo de mídia mas também pelo perfil editorial do veículo associado ao do seu público.

Mas a pressão por esses espaços e por uma maior autonomia do público já começa a mostrar efeitos na própria atuação dos mediadores. Embora não possamos apontar como uma generalização, é emblemático que, nos estudos empreendidos, tenhamos encontrado no quadro "Que Saudade de Você!", programa "Eli Correa", da Rádio Capital a preocupação de veicular a história enviada de forma a satisfazer o público-autor. Paralelamente, nas mídias impressas, além da tradicional reconstrução do relato em primeira pessoa para dar ao leitor a impressão de que está lendo o relato original, na revista Sou + Eu! já aparece a preocupação com a manutenção no texto final de 
regionalismos e expressões típicas presentes na narrativa original do público a fim de reproduzi-la o mais fielmente possível.

No caso específico da web, a questão da ausência de mediação por profissionais de comunicação nos espaços de expressão de narrativa pessoal está em parte relacionada ao fato de que estes espaços não são considerados propriamente jornalísticos. Entretanto, mesmo nas comunidades onde o enfoque informativo está mais presente, há um aumento significativo da autonomia do leitor/autor e a migração da mediação para uma moderação no que se refere aos conteúdos do público. Assim como nos blogs e comunidades não jornalísticos há a adoção do interesse pelo assunto/material para o público como critério para publicação.

Mas, ao mesmo tempo em que na contemporaneidade a voz do público se faz cada vez mais obrigatória, os espaços para isso ainda são muito restritos. Em particular, aqueles destinados às narrativas das histórias pessoais do próprio público, em que pese à expansão das temáticas da intimidade e da valoração do homem comum pelas mídias.

Neste sentido, é importante destacar que já é perceptível o crescimento das vivências privadas como pauta dos veículos de comunicação ainda que com maior espaço nos de perfil editorial mais popular. Entretanto, esse crescimento se dá sempre sob o controle dos veículos e, como expressão direta do público, essas questões da vida privada ainda encontram poucos espaços nas mídias.

No caso da mídia impressa, é particularmente interessante notar também que vários veículos utilizam seu espaço web para permitir ao público interagir com eles e até mesmo participar da produção da versão impressa sem, no entanto, 
permitir essa mesma interação por outros meios (cartas, fax, telefone, ou seja, fora do ambiente web).

Nosso entendimento é de que trata-se de um momento em que os meios vivem uma espécie de conflito em seu interior. Impactados pelas Novas Tecnologias e pelos espaços criados nas mídias digitais para a comunicação direta público-público, os meios tradicionais ainda buscam seus novos modelos e tentam reformular ou adaptar práticas antigas ao mesmo tempo em que defendem o controle estabelecido sobre os fluxos.

O que podemos perceber é que, por mais que essas experiências estejam em franco crescimento, as narrativas do público nos meios tradicionais ainda são fortemente controladas pelas equipes produtoras dos veículos tradicionais.

É como se os meios de comunicação já aceitassem dar ao público o papel de protagonistas das próprias histórias, mas o direito à autoria plena ainda estivesse restrito à internet. 
BI BLI OGRAFI A 


\section{REFERÊNCIAS}

$83 \%$ os fumantes dizem que gostariam de parar. Folha de S. Paulo, 23/09/07, p. C-9, 17, 18 e 19.

A CRIAÇÃO do Rádio: 70 anos de história no Brasil. Disponível em <http://www.radioclaret.com.br/port/frame.htm>. Acesso em 08/07/07.

A HISTÓRIA DA TELEVISÃO: da sua invenção ao início das transmissões em cores. Site Tudo sobre TV. Disponível em $<$ http://tudosobretv.com.br/histortv/histormundi.htm>. Acesso em 03/09/07.

A HISTÓRIA DA TELEVISÃO NO BRASIL. Site Tudo sobre TV. Disponível em <http://www.tudosobretv.com.br/histortv/historbr.htm>. Acesso em 03/09/07.

ABRÃO, Bernadette Siqueira. Além da imaginação - De inimigos a parceiros: homens em ação na Ética IV de Espinosa. São Paulo, 2003. Departamento de Filosofia, Faculdade de Filosofia, letras e Ciências Humanas da USP.

ADAMI, Antônio; BARBOSA FILHO, André. São Paulo nas ondas do rádio. Disponível em

<http://www.jornalismo.ufsc. br/redealcar/cd3/sonora/andrebarbos afilho_antonioadami.doc>. Acesso em 05/08/07.

ADGHIRNI, Zélia Leal. Jornalismo online: em busca do tempo real. In: Congresso Brasileiro de Ciências da Comunicação, XXV, Salvador, 2002. CD-Rom. 
ALONSO, Jaime; MARTí NEZ, Lourdes. Medios I nteractivos:

Caracterización Y Contenidos. In: DíAZ NOCI, Javier; SALAVERRÍA, Ramón. Manual de redacción ciberperiodistica. Barcelona: Ariel, 2003. p. 261-305.

ALSINA, Miquel Rodrigo. La Construcción de la noticia, Barcelona: Paidós, 1996.

ANER. Site. Disponível em <www.aner.org.br>. Acesso em 08/07/07.

ANJ . Site. Disponível em <www.anj.org.br>. Acesso em 08/07/07. ARENDT, Hannah. A Condição Humana. São Paulo: Forense/Edusp, 1981.

AS FORMAS NARRATIVAS em mídias eletrônicas. Site-projeto.

Disponível em <http://www.eca.usp.br/narrativas>. Acesso em 10/09/05.

BABÁ DA NOVELA Páginas da Vida. Vídeo na internet. Site YOUTUBE. Disponível em

$<$ http//br.youtube.com/watch? $=\mid$ ljVhtHzT6I8>. Acesso em 05/09/07.

BAKHTIN, Mikhail. A cultura popular na Idade Média e no Renascimento: o contexto de François Rabelais. 4ạ ed. São PauloBrasília: Hucitec-Edunb, 1999. 419 p.

BALSEBRE, Armand. El lenguaje radiofônico. Madrid: Ediciones Cátedra, 1994.

BAND FM. Site. Disponível em <www. bandfm.com. br>. Acesso em 1 이잉.

BARBEIRO, Heródoto; LIMA, Paulo Rodolfo de. Manual de Radiojornalismo: Produção, Ética e Internet. Rio de Janeiro: Campus, 2001. 
BASSANEZI, Carla Beozzo. Virando as páginas, revendo as mulheres: revistas femininas e relações homem-mulher, 19451964. Rio de Janeiro: Civilização Brasileira, 1996.

BLIG. Site. Disponível em <http://blig.ig.com.br>. Acesso em 12/09/07.

BLOG. Verbete - site Wikipédia. Disponível em <http://pt. wikipedia.org/wiki/Weblog>. Acesso em 15/08/07. BLOGBLOGS. Site. Disponível em $<w w w$. blogblogs.com.br/blogs/top_ranking/1>. Acesso em 20/08/07.

BLOGGER. Site. Disponível em <http://blogger.globo.com. br/index.jsp>. Acesso em 15/07/07. BOLTER, Jay; GRUSIN, Richard. Remediation: Understanding New Media. Massachusetts: MIT Press, 1999.

BORELLI, Viviane. Cobertura midiática de eventos esportivos: uma breve revisão de estudos. In: Congresso Brasileiro da Comunicação, XXIV, setembro 2001, Campo Grande/MS. BOURDIEU, Pierre. Esboço de auto-análise. São Paulo: Companhia das Letras, 2005. Sobre a Televisão. Rio de Janeiro: Jorge Zahar Editor, 1997. BRECHT, Bertolt. Teoria de la Radio (1927-1932). In: BASSETS, Lluis (ed.). De las ondas rojas a las radios libres - textos para la historia de la radio. Barcelona: Gustavo Gili, 1981. BRIGGS, Asa; BURKE, Peter. Uma História Social da Mídia: de Gutenberg à Internet. Rio de Janeiro: Jorge Zahar Ed., 2004. 
BUITONI, Dulcília Helena Schroeder. Mulher de papel - a representação da mulher na imprensa feminina brasileira. São Paulo, Edições Loyola, 1981.

BUCCI, Eugênio. Realidade uma ova!. Revista Teoria e Debate, no . 51 São Paulo, jun/jul/agosto/2002. Disponível em <http://www2.fpa.org. br/portal/modules/news/article. php?storyid $=1799>$. Acesso em 15/06/06.

CALABRE, Lia. Rádio e Imaginação: no tempo da radionovela. In: XXVI Congresso Anual em Ciência da Comunicação, Belo Horizonte/MG, 02 a 06 de setembro de 2003.

CALLIGARIS, Contardo. Verdades de Autobiografias e diários íntimos. In: Revista Estudos Históricos (Rio de Janeiro). 1998; v. Arquivos Pessoais, n. 21. Disponível em: http://www.cpdoc.fgv.br/revista/arq/236.pdf. Acesso em: 19/12/2005.

CANCLINI, Néstor Garcia. Consumidores e Cidadãos: conflitos multiculturais da globalização. Rio de Janeiro: Editora da UFRJ, 1995.

CARVALHO, Ludmila. A vida na Rede. Um estudo sobre os diários online. Facom/UFBA (mimeo). Apud: Lemos, André. A Arte da Vida: diários pessoais e webcams na Internet. In: Congresso Brasileiro de Ciências da Comunicação, XXV, Salvador , 2002.

CASOS DE Família. Programa de TV. Disponível em <http://www.sbt.com.br/casos_familia/programa/>. Acesso em 28/09/07.

CASTELLS, Manuel. A Sociedade em Rede. Volume I - A Era da Informação: economia, sociedade e cultura. São Paulo: Paz e Terra, 1999.

CERTEAU, Michel de. A invenção do cotidiano, Volume 1. Artes de 
fazer. Petrópolis: Vozes, 1994.

CHALABY, J ean. O J ornalismo como invenção anglo-americana: Comparação entre o desenvolvimento do jornalismo francês e anglo-americano (1830-1920). Disponível em:

<http://revcom. portcom. intercom.org.br/scielo. php?script=sci_artt ext\&pid=S1645-56812003000300004\&lng=pt\&nrm=iso>. Acesso em: 03/05/2006.

CHARTIER, Roger. A aventura do livro: do leitor ao navegador. São Paulo: Editora UNESP/Imprensa Oficial do Estado de São Paulo, 1999.

COMUNIDADE VIRTUAL. Verbete - site Wikipedia. Disponível em <http://pt.wikipedia.org/wiki/Comunidade_virtual>. Acesso em 15/08/07.

CORBIN, Alain; PERROT, Michelle. El secreto del individuo. In: ARIES, Philippe; DUBY, Georges. Historia de la vida privada, v. 8: Sociedad burguesa: aspectos conrretos de la vida privada. Madri: Taurus, 1991.

CORREI A, J oão Carlos. O Poder do J ornalismo e a Mediatização do Espaço Público. Disponível em:

<http://www. bocc.ubi.pt/pag/jcorreia-poder-jornalismo.pdf > Acesso em: 23/03/2006.

COSTA, Ana Beatriz de Paiva. Uma compreensão da arte a partir da tragédia. 2004. Disponível em:

<http://br.geocities.com/anpap_2004/textos/chtca/ana_beatriz_co sta. pdf> Acesso em: 06/02/07.

COSTA, Ana Cláudia. O fim da paz na via expressa. O Globo, 19/09/07, p. 15.

COSTA, Caio Túlio. Ferramenta para o Entendimento. Prefácio. In: SPYER, Juliano. Conectado - o que a Internet fez com você e o que 
você pode fazer com ela, Rio de Janeiro: J orge Zahar Ed., 2007. p. 9-14.

COSTA, Maria Cristina Castilho. Interatividade - entre graus de liberdade e intencionalidades narrativas. In: Congresso Brasileiro de Ciências da Comunicação, XXVII, 2004, Porto Alegre. CD-Rom. DENISE FRAGA em RETRATO FALADO (DVD). 2000-2005. TV Globo Ltda.

DIAS, Cláudia. Estudo de caso: idéias importantes e referências. Disponível em: <http://www.geocities.com/claudiaad/casestudy.pdf> Acesso em: 25/05/2006.

DíAZ NOCl, Javier; SALAVERRÍ A ALIAGA, Ramón. Manual de Redacción Ciberperiodística. Barcelona: Ariel Comunicacion, 2003.

DUMARESQ, Daniela. Viagens e Encontros em Brasil Legal.

Disponível em <http://reposcom. portcom. intercom.org.br/bitstream/1904/4648/1 /NP7DUMARESQ.pdf >. Acesso em 03/12/2006.

ÉPOCA. Site. Disponível em <www.epoca.com.br>. Acesso em 08/09/07.

ESCH, Carlos Eduardo. O futuro dos comunicadores e a reinvenção do rádio. In: MOREIRA, Sônia Virgínia; DEL BIANCO, Nélia (orgs). Desafios do rádio no século XXI. Rio de Janeiro: Intercom/UERJ, 2001.

ESPINOSA, Baruch de. Pensamentos Metafísicos/Tratado da Correção do Intelecto/Ética/Tratado Político/Correspondência. 1ạ ed. São Paulo: Abril Cultural, 1973. (Os Pensadores.) v. XVII. ESPINOZA, Karina Hortencia Salazar. O ciberleitor do jornal digital (Estudo de caso do site de informação NetEstado). São Paulo: ECA/USP, 2000. (Dissertação de Mestrado) 
EXTRA. Site. Disponível em <http://extra.globo.com/>. Acesso em 29/09/07.

FERENCZI, T. L'Invention du journalisme en France. Paris: Plon, 1993.

FERNANDES, Luciane Alves; GOMES, J osé Mario Matsumura. Relatórios de pesquisa nas ciências sociais: características e modalidades de investigação. Disponível em:

<http://www. ufrgs.br/necon/04-

4\% 20Relat\% C3\% B3rios $\% 20$ de $\% 20 \%$ pesquisa $\%$ 20nas $\% 20$ ci $\%$ C3 $\%$ AAncias $\% 20$ sociais\% 20-\% 20Luciane\% 20e\% 20J o.pdf> Acesso em: 15/05/2006.

FERREIRA, Fernando. Muro das lamentações. O Estado de S. Paulo, 23/09/07, p. A3.

FIDLER, Roger. Mediamorphosis: understanding new media. California: Pen Forge Press, 1996.

FISCHER, Gustavo Daudt. A condição de sujeito como autorprodutor nos diários. In: Congresso Brasileiro de Ciências da Comunicação, XXVII, Porto Alegre, 2004. CD-Rom.

FISHER, Rosa Maria Bueno. Uma análise foucaultiana da TV: das estratégias de subjetivação na cultura, p. 46. In: Currículo sem Fronteiras, v. 2, n. 1, p. 41-54, Jan/J un 2002. Disponível em <www.curriculosemfronteiras.org>>. Acesso em 05/07/2007. FLORIANI, Adriano Warken; MORIGI, Valdir J osé. Circuitos Comunicativos e Construção da Cidadania no Ciberespaço: Tramas do Sentido em Narrativas de Weblogs Disponível em: <http://reposcom. portcom. intercom.org. br/bitstream/1904/18030/ 1/R0294-1.pdf>. Acesso em: 11/04/2006. FONTANELLA, Fernando Israel; PRYSTHON, Angela. Trocando figurinhas: sobre Orkut, frivolidades, neotribalismo e flânerie. In: 
Encontro de Núcleos de Pesquisa da Intercom, IV, Porto Alegre. , 2004. CD Rom. Acesso em: 18/01/2005.

FOUCAULT, Michel. Histoire de la sexualité I. La volonté de savoir, Paris: Gallimard, 1976. Apud: CALLIGARIS, Contardo. Verdades de Autobiografias e diários íntimos. In: Revista Estudos Históricos (Rio de Janeiro). 1998; v. Arquivos Pessoais, n. 21. Disponível em <http://www.cpdoc.fgv.br/revista/arq/236. pdf>. Acesso em 19/12/2005.

FRAGA, Denise [Et Al.]. Retrato Falado - Histórias fantásticas da vida real. São Paulo: Globo, 2005.

FRANCISCATO, Carlos Eduardo. A Atualidade no J ornalismo. Revista da Compós, v. GT Estudos de Jornalismo, 2000.

GANNETT, Cinthia. Gender and the J ournal - Diaries ad Academic Discourse, apud OLIVEIRA, Rosa Meire Carvalho de. Diários Públicos, mundos privados: Diário íntimo como gênero discursivo e suas transformações na contemporaneidade. Salvador, UFBA: 2002. (Dissertação de Mestrado), p. 28.

GILLMOR, Dan. Nós, Os Media. Lisboa: Editorial Presença, 2005. GOMES, Mayra Rodrigues. Repetição e diferença nas reflexões sobre comunicação. São Paulo: Annablumme, 2001.

GOOGLE. Site. Disponível em <www.google.com.br>. Acesso em 10/07/07.

HABERMAS, Jürgen. Mudança Estrutural da Esfera Pública. Rio de J aneiro: Bom Tempo Universitário, 1984.

HALL, Stuart. A identidade cultural na pós-modernidade. 3a ed. Rio de Janeiro: DP\&A, 1999. 
HIME, Gisely Valentim Vaz Coelho. A Hora e a Vez do Progresso Cásper Líbero e o Exercício do Jornalismo nas páginas d’A Gazeta. São Paulo: ECA/USP, 1997. (Dissertação de Mestrado) . Página Feminina: o ponto de encontro da Mulher Moderna - estudo analítico da pauta feminina do vespertino paulistano A Gazeta (1929-1943). São Paulo: ECA/USP, 2002. (Tese de Doutorado) IBOPE. Site. Disponível em <www. ibope.com.br>. Acesso em 08/08/07.

IDG NOW!. Site. Disponível em <http://idgnow.uol.com.br/>. Acesso em 15/07/07.

IG. Site. Disponível em <www.ig.com.br/>. Acesso em 15/07/07. INAGAKI, Alexandre. 25 momentos da blogosfera brasileira. In: Revista Época. Disponível em <http://revistaepoca.globo.com/Revista/Epoca/1,,EDG749425856,00.html> . Acesso em 12/09/07.

INFO ONLINE. Site. Disponível em <http://info.abril.com.br/>. Acesso em 15/07/07.

JUSTIN'S LINKS from de Underground. Site. Disponível em $<$ www.links. net>. Acesso em 02/10/07.

LACAN, Jacques. O eu na teoria de Freud e na técnica da psicanálise. Rio de Janeiro: Jorge Zahar Editor, 1985. (O Seminário.) v. Livro 2.

LAGE, Nilson. Controle da Opinião Pública - um ensaio sobre a verdade conveniente. Petrópolis: Vozes, 1998. 406 p.

LANA, Ligia Campos de Cerqueira. Brasil Urgente: cotidiano e sujeitos populares nas telas da TV. In: Intercom Sudeste 2006 - XI 
Simpósio de Ciências da Comunicação na Região Sudeste. Ribeirão Preto, SP - 22 a 24 de maio de 2006. Disponível em <http://www.unifra.br/professores/13707/brasilurgente. pdf>>. Acesso em 13/07/07.

LEAL, Fred. Lord Internet. In: Play. Disponível em <http://web.archive.org/web/20030115173928/www.pl4y.com.br/ players/ler.asp?id=51814> . Acesso em 12/09/07.

LEAL, Renata. Você faz a notícia. In: Revista Época. Disponível em < http://revistaepoca.globo.com/Revista/Epoca/0,,EDG750526014-430-1,00.html>. Acesso em 11/10/07.

LEJ EUNE, Phillipe. El Pacto Autobiográfico y Otros Estúdios. Madrid: Megazul-Endymion, 1986.

LEMOS, André. A Arte da Vida: diários pessoais e webcams na Internet. In: Congresso Brasileiro de Ciências da Comunicação, XXV, Salvador, 2002.

LUHMANN, Niklas. Introducción a la Teoria de Sistemas. Barcelona: Anthropos, 1996.

MAFFESOLI, Michel. No fundo das aparências. $2^{a}$ ed. Petrópolis: Vozes, 1996.

MAIA, Marta Regina. Quadros radiofônicos: memórias da comunidade radiouvinte paulistana (1930-1950). São Paulo: ECA/USP, 2002. (Tese de Doutorado) MAIOR, Marcel Souto; Pesquisa Memória Globo. Almanaque da TV Globo. São Paulo: Globo, 2006. 
MANDEL, Arnaldo; SIMON, Imre; DELYRA, Jorge L. Informação: computação e comunicação, Revista USP, São Paulo: no 35: 10-45, set./nov. 1997.

MANOVICH, Lev. The Language of New Media. Cambridge, Mass: MIT Press, 2001.

MÁRCIA. Programa de TV. Disponível em <http://www.band.com.br/marcia/sobre.asp?ID=407>. Acesso em 28/09/07.

MARCONDES FILHO, Ciro. Perca tempo - É no lento que a vida acontece. São Paulo: Paulus, 2005. . Sociedade Tecnológica. 1a ed. São

Paulo: Editora Scipione, 2004. . TV Interativa. Atrator Estranho no 14.

Disponível em

<http://www.eca.usp.br/nucleos/filocom/ae14.html>. Acesso em $15 / 08 / 06$.

MARTÍN-BARBERO, J esús. Cidade Virtual: Novos Cenários da Comunicação. Revista Comunicação \& Educação, São Paulo, v. 11, p. 53-67, jan/abr 1998.

MARX, Karl; ENGELS, Friedrich. A ideologia alemã I - Feuerbach. São Paulo: Hucitec, 1999.

MATTELART, Armand. A Globalização da Comunicação. Bauru: EDUSC, 2002.

MATTOS, Laura. Ex-prostituta Bruna Surfistinha deve lançar filme sobre sua vida. In: Folha Online. 08/04/07. Disponível em <http://www1.folha.uol.com.br/folha/ilustrada/ult90u70086.shtml >. Acesso em 10/05/07. 
MCLEISH, Robert. Produção de Rádio - um guia abrangente de produção radiofônica. 1a ed. São Paulo: Summus Editorial, 2001. MCLUHAN, Marshall. Os meios de comunicação como extensões do homem. 10a ed. São Paulo: Cultrix, 2000.

MEDITSCH, Eduardo. A Rádio na Era da Informação: Teoria e Técnica do Novo Radiojornalismo. Coimbra: Livraria Minerva Editora, 1999.

MENDES, José Maria Ribeiro Mendes apud CORREI A, J oão Carlos, O Poder do Jornalismo e a Mediatização do Espaço Público. Disponível em: <http://www.bocc.ubi.pt/pag/jcorreia-poder-jornalismo. pdf > Acesso em: 23/03/2006.

MICROFONE (site). Disponível em <http://www.microfone.jor.br/historia.htm>. Acesso em 06/07/07. MINIAURÉLI O: o minidicionário da língua portuguesa - 6a edição revista e atualizada. Curitiba: Posigraf, 2004.

MINISTÉRIO DAS COMUNICAÇÕES. Site. Disponível em $<$ www.mc.gov.br>. Acesso em 08/07/07.

MIX FM. Site. Disponível em <mixfm.ig.com.br>. Acesso em $1 \cong / 10 / 07$.

MONTEIRO, Luís. A Internet como meio de comunicação: possibilidades e limitações. In: XXIV Congresso Brasileiro da Comunicação. Campo Grande/MS, setembro de 2001. Disponível em

<http://reposcom. portcom.intercom.org.br/bitstream/1904/4714/1 /NP8MONTEIRO.pdf>. Acesso em 18/09/07.

MORIN, Edgar. A inteligência da complexidade, São Paulo:

Peirópolis, 2004. 
MULTIGNER, Giles. Sociedad interactiva o sociedad programada? Apud: SILVA, Marco. O que é Interatividade. Boletim Técnico do Senac, v. 24, n. 2, Mai/Ago 1998. Disponível em <http://www. senac. br/informativo/BTS/242/boltec242d.htm>. Acesso em: 24/01/2005.

MUSEU DA PESSOA. Site. Disponível em <www.museudapessoa.com.br/>. Acesso em 19/10/07.

NATIVA FM. Site. Disponível em <www. nativa.com.br>. Acesso em $1 ㅇ 10 / 07$.

NEVES, José Luis. Pesquisa Qualitativa - Características, Usos e Possibilidades, Caderno de Pesquisas em Administração, São Paulo, v. 1, n. 3, 2o sem/1996. <http://www. ead.fea.usp.br/cadpesq/arquivos/C03-art06.pdf>. Acesso em 20/05/06.

NIELSEN, Jakob. How users read on the Web. 1997. Disponível em <http://www. useit.com/alertbox/9710a.html>. Acesso em 20/04/07.

NOSSA HISTÓRIA. Site do Museu da Pessoa. Disponível em <http://www.museudapessoa.com.br/oquee/oque_nossahistoria.sh tml>. Acesso em 19/10/07.

O DIÁRIO DE Bruna Surfistinha. Disponível em $<w w w$. brunasurfistinha.com/blogs/ >. Acesso em 15/09/07. O GLOBO. Site. Disponível em <www.oglobo.com.br>. Acesso em 29/09/07.

OHMYNEWS. Site. Disponível em <http://english.ohmynews. com/>. Acesso em 25/06/07. OLIVEIRA, Rosa Meire Carvalho de. Diários Públicos, mundos privados: Diário íntimo como gênero discursivo e suas 
transformações na contemporaneidade. Salvador, UFBA: 2002. (Dissertação de Mestrado)

ORKUT. Site. Disponível em <www. orkut.com>. Acesso em 08/10/07.

ORTRIWANO, Gisela Swetlana. A informação no Rádio - os grupos de poder e a determinação dos conteúdos. São Paulo: Summus Editorial, 1985.

A invasão dos marcianos: A Guerra dos Mundos que o rádio venceu. Disponível em <http://www.igutenberg.org/guerra124.html>. Acesso em 10/08/07.

. Rádio: interatividade entre rosas e espinhos. 2000. Disponível em <http://bocc.ubi. pt/pag/ortriwanogisela-radio-interactividade. html>. Acesso em 15/12/2000.

OVERMUNDO. Site. Disponível em <www.overmundo.com.br>. Acesso em 05/07/07.

PALÁCIOS, Marcos. O Medo do Vazio: Comunicação, Sociabilidade e Novas Tribos. In: Idade Mídia. Salvador: Edufba, 1995.

PC WORLD. Site. Disponível em <http://pcworld.uol.com.br/>. Acesso em 15/07/07.

PENA, Felipe. Celebridades e heróis no espetáculo da mídia. In: Intercom, v. 25, n. 1, p. 146-57, 2002. Disponível em <http://revcom. portcom. intercom.org.br/scielo. php?script=sci_artt ext\&pid=S0102-64532002000100010\&lng=es\&nrm=iso >. Acesso em 15/08/06.

PEREIRA, Vinícius Andrade. Marshall McLuhan, o conceito de determinismo tecnológico e os estudos dos meios de comunicação contemporâneos. In: UNI revista - Vol.1, no 3, jul. 2006. Disponível 
em

<http://www.unirevista.unisinos.br/_pdf/UNI rev_VAndrade.PDF>. Acesso em 20/10/07.

PINHEIRO JUNIOR, Gilberto. Antropologia e Comunicação: diálogo possível e necessário. Educação \& Sociedade, Campinas, v. 24, no 85, p. 1407-1414, dezembro 2003. Disponível em <http://www.cedes.unicamp.br>. Acesso em: 21/03/07.

POBRE DINAMARCA. Veja, Ed. 2027, ano 40, no 38, 26/09/07, p. 44.

POÉTICA. Verbete - site Wikipédia. Disponível em <http://pt.wikipedia.org/wiki/Po\% C3\%A9tica>. Acesso em $15 / 09 / 06$.

POLISTCHUK, Ilana; TRI NTA, Aluizio Ramos. Teorias da Comunicação - o pensamento e a prática da comunicação social. Rio de Janeiro: Editora Campus, 2002.

POR UM PUNHADO de Pixels. Post de 18/08/07. Disponível em <http://www.nemonox.com/ppp/archives/2007_08.html>. Consultado em 05/09/07. POSTMAN, Neil. Amusing ourselves to death: public discourse in the age of show business. Nova York: Penguin Books, 1985. . Tecnopólio - A rendição da cultura à tecnologia.

São Paulo: Nobel, 1994.

PRIMO, Alex F. T. e CASSOL, Márcio B. F.. Explorando o Conceito de interatividade: definições e taxonomias. Disponível em <http://usr.psico. ufrgs.br/ aprimo/pb/espiralpb.htm>. Acesso em $15 / 10 / 07$.

PUZZLE DIÁRIO. Site. Disponível em <http://puzzlediario.blogspot.com/>. Acesso em 22/10/07. 
RÁDI O BANDEIRANTES. Site. Disponível em

<http://radiobandeirantes.terra.com. br/>. Acesso em 17/09/07.

RÁDI O CAPITAL. Site. Disponível em

<http://radiocapital.am.com.br/>. Acesso em 17/09/07.

RÁDIO GLOBO. Site. Disponível em

<http://globoradio.globo.com/MusicCenter/0,,4864,00.html>.

Acesso em 17/09/07.

RÁDI O JOVEM PAN. Site. Disponível em

<http://jovempan.uol.com.br/jpamnew/>. Acesso em 17/09/07.

REALITY SHOW. Verbete - Site Wikipedia. Disponível em <http://pt.wikipedia.org/wiki/Reality_show>. Acesso em 05/06/07.

REDE GLOBO DE TELEVISÃO. Site. Disponível em <http://redeglobo.globo.com>. Acesso em 02/09/07.

REDE RECORD DE TELEVISÃO. Site. Disponível em $<w w w$. rederecord.com.br/home.asp $>$. Acesso em 02/09/07.

REDE BANDEIRANTES DE TELEVISÃO. Disponível em <http://band.com.br/home.asp>. Acesso em 02/09/07. RESENDE, Fernando Antônio. Textuações - ficção e fato no Novo Jornalismo de Tom Wolfe. São Paulo: Annablumme/FAPESP, 2002. $128 \mathrm{p}$.

RHEI NGOLD, Howard. A Comunidade Virtual. Lisboa: Gradiva., 1996.

RIBEIRO, Renato J anine. Memórias de si, ou... Revista Estudos Históricos, Rio de Janeiro, n. 21, 1998. http: //www.cpdoc.fgv.br/revista/arq/235. pdf. Acesso em: 03/01/05. 
ROCHA, Debora Cristine. O Museu da Pessoa - a Tradição Oral como Acervo Digital, São Paulo: PUC/SP, 2004. (Dissertação de Mestrado)

ROUANET, Sérgio Paulo. Mal-estar na Modernidade. São Paulo: Companhia das Letras, 1993.

RUIZ, Castor Bartolomé. Os Paradoxos do Imaginário. São Leopoldo: Editora Unisinos, 2003.

SAAD, Beth. Estratégias para a mídia digital: Internet, informação e comunicação. São Paulo: Editora Senac São Paulo, 2003.

SALAVERRíA, Ramón; SÁDABA, Charo (eds.). Towards New Media Paradigms: Content, Producers, Organisations and Audiences. Pamplona: Ediciones Eunate, 2004.

SAMPAIO, Paulo; GIANNINI, Deborah. Dinheiro na mala é vendaval. Folha de S. Paulo, São Paulo, 17/07/2005. Revista da Folha, 678, p. 8-13.

SANTORO, André Cioli Taborda. Fato consumado: a presença da ficção na mídia impressa. São Paulo: PUC/SP, 2004. (Dissertação de mestrado)

SANTOS, Adriana Bacellar Leite e. Os Meios de Comunicação como Extensões do Mal-Estar. Rio de Janeiro: Mauad, 2002.

SANTOS, Bruno de Aragão. O real enquanto narração: um diálogo entre o jornalismo literário e a antropologia interpretativa. In: Congresso Brasileiro de Ciências da Comunicação, XXVIII., 2005, Rio de Janeiro. CD-Rom.

SAROLDI, Luiz Carlos; MOREI RA, Sônia Virgínia. Rádio nacional - O Brasil em sintonia. Rio de J aneiro: FUNARTE/Instituto Nacional de Música/Divisão de Música Popular, 1984. 
SBT. Site. Disponível em <www.sbt.com.br/>. Acesso em 02/09/07.

SCHITTINE, Denise. Blog: comunicação e escrita íntima na internet. Rio de Janeiro: Civilização Brasileira, 2004.

SCHIWY, Marlene. A Voice of Her Own - Women and the Journal Writing J ourney. New York: Fireside, 1996. Apud: OLIVEIRA, Rosa Meire Carvalho de. Diários Públicos, mundos privados: Diário íntimo como gênero discursivo e suas transformações na contemporaneidade. Salvador, UFBA: 2002. (Dissertação de Mestrado)

SENNETT, Richard. O declínio do homem público - as tiranias da intimidade.São Paulo: Companhia das Letras, 2001.

SFEZ, Lucien. Crítica da Comunicação. 2a ed. São Paulo: Edições Loyola, 2000.

SIBILIA, Paula. Os diários íntimos na Internet e a crise da interioridade psicológica. 2003. Disponível em: <http://www. comunica.unisinos.br/tics/textos/2003/GT12TB6.PDF $>$ Acesso em: 10/01/07.

SIGNATES, Luiz. Comunicação e Paz, In: X Encontro Latinoamericano de Faculdades de Comunicação Social, 2000, São Paulo. Disponível em <www.ipepe.com.br/paz.html>. Acesso em: 20/09/2004.

SILVA, Marco. O que é Interatividade. Boletim Técnico do Senac, v. 24, n. 2, Mai/Ago 1998. Disponível em <http://www.senac.br/informativo/BTS/242/boltec242d.htm>. Acesso em: 24/01/2005.

SLASHDOT. Site. Disponível em <http://slashdot.org/>. Acesso em 10/08/07. 
SODRÉ, Nelson Werneck. História da Imprensa no Brasil. Rio de J aneiro: Civilização Brasileira, 1966.

SOU + EU! chega ao mercado para revolucionar o jornalismo. Release de divulgação. 2006, 5 p.

SPYER, Juliano. Conectado - o que a Internet fez com você e o que você pode fazer com ela, Rio de Janeiro: Jorge Zahar Ed., 2007. TERRA. Site. Disponível em <www.terra.com.br/>. Acesso em 15/07/07.

TESSER, Tereza Cristina. De passagem pelos estúdios - a presença feminina no início do Rádio no Rio de Janeiro e São Paulo. São Paulo: ECA/USP, 1994. Dissertação de Mestrado.

THE BOBS. Site. Disponível em <http://www.thebobs.com>. Acesso em 30/09/07.

THE WELL. (Site). Disponível em <www.well.com>. Acesso em $19 / 10 / 07$.

TINHORÃO, J osé Ramos. Música Popular: do gramofone ao rádio e TV. São Paulo: Ática, 1981.

TIRABOSCHI, Juliana. Você é o repórter. In: Revista Galileu. Disponível em <http:// revistagalileu. globo. com/Revista/Galileu/0,,EDG787107943-194,00.html> . Acesso em 10/09/2007.

TODOROV, Tzvetan. As estruturas narrativas. São Paulo: Perspectiva, 1970.

TORQUE Internet. Disponível em <http://www.torque.com. br/internet/historia.htm>. Acesso em 30/09/07. 
TRANSCONTI NENTAL FM. Site. Disponível em $<w w w$.transcontinentalfm.com.br/index.asp?act=0\&id_area_site_w $\mathrm{n}=0>$. Acesso em 1이잉.

TRIGO-DE-SOUZA, Ligia Maria. Rádios@Internet - O desafio do áudio na rede. São Paulo: ECA/USP, 2002 (Dissertação de Mestrado).

TRIVINHO, EUGÊNIO. Redes: obliterações no fim do século. São Paulo: Annablumme/FAPESP, 1998. 154 p.

TUDO SOBRE TV. Disponível em <http://www.tudosobretv.com.br/histortv/histormundi.htm>. Acesso em 03/09/07.

TUPI FM. Site. Disponível em <www.radiotupifm.com.br>. Acesso em 1 의 10/07.

UOL. Site. Disponível em <www.uol.com.br/>. Acesso em 20/07/07.

UOL BLOG. Site. Disponível em <http://blog.uol.com.br/>. Acesso em 15/07/07.

VALLE, Luciane Ribeiro do. Que saudade de você: a construção de uma dramaturgia radiofônica. São Paulo: ECA/USP, 2001.

VILCHES, Lorenzo. Tecnologia Digital: Perspectivas Mundiais. Comunicação \& Educação, São Paulo, n. 26, p. 43-61, jan/abr 2003.

VIRILIO, Paul. O Espaço Crítico. Rio de Janeiro: Editora 34, 1993.

VIRUNDUNS. Site. Disponível em <www.interney.net/blogs/virunduns >. Acesso em 12/09/07. VIVA SP. Site. Disponível em <www.vivasp.com>. Acesso em 26/10/07. 
WEBINSIDER. Site. Disponível em <www. webinsider.uol.com. br>. Acesso em 15/07/07.

WI LLI AMS, Raymond. Cultura e Sociedade. São Paulo: Cia Ed. Nacional, 1969.

. Keywords. Londres: Fontana, 1976. Apud:

HALL, Stuart. A identidade cultural na pós-modernidade. 3aㅡ ed. Rio de Janeiro: DP\&A, 1999.

WOLF, Mauro. Teorias da Comunicação. Lisboa: Editorial Presença, 1999. 271 p., v. 5.

WOLTON, 1995, p. 167 apud CORREIA, João Carlos. O Poder do Jornalismo e a Mediatização do Espaço Público, p. 3. Disponível em: <http://www.bocc.ubi. pt/pag/jcorreia-poder-jornalismo. pdf > Acesso em: 23/03/2006.

XINRAN, Xue. As boas mulheres da China. São Paulo: Companhia das Letras, 2003.

YIN, Robert K. Estudo de caso - planejamento e métodos. Porto Alegre: Bookman, 2005.

YONAHA, Liuca. 49 milhões de brasileiros usam a Internet. In: Jornal Destak. Disponível em <http://www. destakjornal.com. br/noticia. asp?ref=10506>. Acesso em 1이잉.

ZAMORIM. Site. Disponível em <www.zamorim.com>. Acesso em 02/10/07. 


\section{BI BLI OGRAFI A CONSULTADA}

BAUDRILLARD, Jean. Tela total: mito-ironias da era do virtual e da imagem. Porto Alegre: Sulina, 1997.

BOURDIEU, Pierre. O Poder Simbólico, Rio de Janeiro: Bertrand Brasil, 2003.

BRITTES, Juçara Gorski. A revitalização da esfera pública habermasiana pela comunicação ciberespacial. In: Congresso Brasileiro de Ciências da Comunicação, XXVII. Porto Alegre, 2004. CD Rom.

CÂNDIDO, Celso. A filosofia do ciberespaço. http://caosmose. net/candido. Acesso em: 24/11/2005.

CASTELLS, Manuel. O poder da Identidade. Volume II - A Era da Informação: economia, sociedade e cultura. São Paulo: Paz e Terra, 1999/2000.

CASTELLS, Manuel. Fim de Milênio. Volume III - A Era da Informação: economia, sociedade e cultura. São Paulo: Paz e Terra, 2000.

CORREAA, ELIZABETH SAAD. Arquitetura Estratégica no horizonte da terra cognita da informação digital. Revista USP, São Paulo, v. no 48, p. 100-18, 2000.

COSTA, Célia Leite. Intimidade versus Interesse Público: a Problemática dos Arquivos. Revista Estudos Históricos, Rio de Janeiro, n. 21, 1998 20/12/2005.

http://www.cpdoc.fgv.br/revista/arq/245.pdf.

DORIA, Pedro. Zen-bloguismo. Folha de S. Paulo, São Paulo, 17/07/2005. Revista da Folha, 678, p. 4. 
FREUD, Sigmund. O Mal-Estar na Civilização. Rio de Janeiro: Imago Ed., 1997. $116 \mathrm{p}$.

GARCIA, Maria Madalena A. de M. Machado. Os Documentos Pessoais no Espaço Público. Revista Estudos Históricos, Rio de Janeiro, n. 21, 1998 http://www.cpdoc.fgv.br/revista/arq/244.pdf. Acesso em: 15/12/2005.

GIDDENS, Anthony. Modernidade e identidade. Rio de Janeiro: J orge Zahar Editor, 2002.

HABERMAS, Jürgen. O Discurso Filosófico da Modernidade. São Paulo: Martins Fontes, 2002

HABERMAS, Jürgen. Racionalidade e Comunicação. Lisboa: Edições 70, 1996. (Biblioteca de Filosofia Contemporânea.) v. 32.

LAGE, Nilson. Estrutura da Notícia, São Paulo: Ática, 1999.

LEÃO, Lúcia (org). O Chip e o caleidoscópio - reflexões sobre as novas mídias. São Paulo: Editora Senac São Paulo, 2005.

LI MA, Alceu Amoroso. O jornalismo como gênero literário. Rio de Janeiro: Agir, 1990.

LIMA, Edvaldo Pereira. Páginas ampliadas - o Livro-reportagem como extensão do J ornalismo e da Literatura. Campinas: Unicamp, 1993.

LI MA, Fernando Barbosa. Nossas câmeras são seus olhos. Rio de Janeiro: Ediouro, 2007.

MACHADO, Arlindo. A televisão levada a sério. São Paulo: Senac, 2000.

MAFFESOLI, Michel. O tempo das tribos: o declínio do individualismo nas sociedades de massa. Rio de Janeiro: ForenseUniversitária, 2000. 
MARCONDES FILHO, Ciro. O Espelho e a Máscara: o enigma da Comunicação no Caminho do Meio, Ijuí: Editora Unijuí, 2002. . Jürgen Habermas II: da esfera pública crítica à ação comunicativa. 2005. Apostila para disciplina "A Crítica Alemã" Pós-Graduação em Ciências da Comunicação, ECA, USP.MARTín-BARBERO, J esus. Dos Meios às Mediações, Rio de Janeiro: Ed. UFRJ, 2001.

MEDI NA, Cremilda. A Arte de Tecer o Presente - Narrativas e Cotidiano, São Paulo: Summus, 2003 . Povo e Personagem Canoas: Ulbra, 1996.

MENESES, Ulpiano T. Bezerra. Memória e cultura material: documentos pessoais no espaço público. Revista Estudos Históricos. Rio de Janeiro e Brasília, n. 21, 1998. http://www.cpdoc.fgv.br/revista/arq/238. pdf. Acesso em: 26/12/05.

MIELNICZUK, Luciana. Características e implicações do jornalismo na Web. Disponível em:

<http://www.facom.ufba.br/jol/pdf/2001_mielniczuk_caracteristica simplicacoes. pdf> Acesso em: 02/04/2006.

MORIN, Edgar. Introducción al pensamiento complejo. Barcelona: Gedisa, 1994.

MUNIZ SODRÉ. O monopólio da fala - função e linguagem da televisão no Brasil, Petrópolis: Vozes, 2001.

PEUCER, Tobias. Os relatos jornalísticos, Revista Comunicação e Sociedade no 33, p. 199-214, 2000.

PRETI, Dino. A linguagem da TV: o impasse entre o falado e o escrito. In: Novaes, Adauto (org) Rede imaginária, televisão e democracia. São Paulo: Companhia das Letras, 1992, p. 232-9. 
RICOEUR, Paul. Tempo e Narrativa (Tomo I). Campinas: Papirus, 1994.

. Tempo e Narrativa (Tomo II). Campinas: Papirus,

1995.

. Tempo e Narrativa (Tomo III). Campinas: Papirus,

1997.

SEIXAS, Lia. O Lugar da Narrativa no Hipertexto J ornalístico - uma análise do conceito de narrativa na webnotícia In: Encontro Nacional de Pesquisadores em Jornalismo, III, Florianópolis, 2005.

TRAQUINA, Nelson. O estudo do jornalismo no século XX, São Leopoldo: Editora Unisinos, 2003; Jornalismo, Lisboa: Quimera, 2002.

TRINTA, Aluízio Ramos. A função cognitiva do jornalismo, Anais do XXVII Congresso da Intercom, Porto Alegre, 2004.

VILCHES, Lorenzo. La televisón: los efectos del bien y del mal, Barcelona: Paidós, 1999. 
ANEXOS 


\section{Anexo 1}

-- Original Message ---

From: Cynthia Greiner

To: Ligia Trigo

Sent: Tuesday, July 04, 2006 8:07 PM

Subject: RES: tese

Oi, Ligia

aí vão as suas respostas.

Cynthia

-----Mensagem original-----

De: Ligia Trigo

Enviada em: terça-feira, 4 de julho de 2006 19:21

Para: Cynthia Greiner

Assunto: Fw: tese

Prioridade: Alta

Prezada Cynthia,

Mandei essa mensagem há mais de 15 dias para o atendimento ao leitor e não obtive nenhuma resposta...

Como estou na fase de definição dos casos que adotarei para o estudo, solicito sua ajuda no sentido de encaminhar a quem possa responder...

obrigada/

Ligia Maria Trigo-de-Souza

Doutoranda da ECA-USP

Assessora de Comunicação da Faculdade de Medicina da USP

----- Original Message -----

From: Ligia Trigo

To: nova.abril@atleitor.com.br

Sent: Saturday, June 17, 2006 4:57 PM

Subject: tese

Olá,

estou fazendo meu doutorado sobre o espaço que os meios de comunicação oferecem para a publicação/veiculação de histórias pessoais e queria saber algumas informações iniciais sobre a seção de depoimentos de leitores de vocês.

- Desde quando existe? Depoimentos fazem parte da fómula de NOVA, desde sempre

- Por que foi criado? Substituiu o "Eu, Leitora de Nova"? Por quê? Histó ria s rea is sã o uma excelente maneira de passarconhecimento, informação, lições de vida 
- Vocês trabalham apenas com relatos recebidos ou também buscam histórias de leitoras (sobre um determinado assunto, por exemplo)? Ta mbém va mos a trás

- Qual a média de relatos/mês que vocês recebem? Diga mos cerca de 10 a 20

- Há algum profissional responsável pela seção? Quem é? Qual seu contato? Não, não há. Qualquer editora pode ficar responsá vel pela seção na quele mês

\section{Obrigada/}

Ligia Maria Trigo-de-Souza

Doutoranda - Escola de Comunicações e Artes da USP 


\section{Anexo 2}

From: Fernanda Cirenza - Redação Marie Claire - Editora Globo

Sent: Fri 10/12/2007 18:37:09

To : Ligia Trigo

Subject: Respondendo

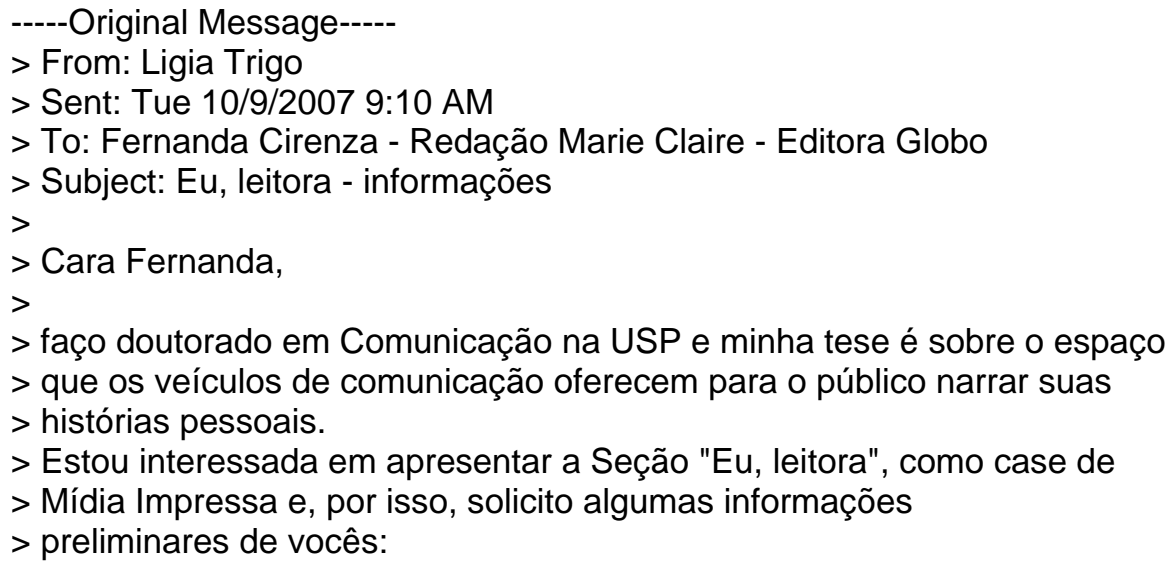

- Como surgiu a seção? É publicada desde quando?

A seção surgiu com o lançamento

da revista Marie Claire no Brasil, que fez 16 anos em abril de 2007. A idéia de texto "aspeado", para usar um jargão jornalístico, para narrar uma história sob o ponto de vista do protagonista (ou seja, daquele que viveu ou vive a história)é uma marca de Marie Claire --não só a brasileira, como as edições estrangeiras. MC no Brasil publica essa seção desde a primeira edição, em 1991.

- Os depoimentos são espontâneos ou a Revista busca esses relatos? A revista recebe diariamente cartas e emails de leitoras (e leitores também) interessados em ver suas histórias publicadas em MC. Evidentemente, que a revista seleciona os casos. Quer dizer, a história precisa realmente interessar à revista. Alguns quesitos precisam ser considerados, ou seja, não basta ter uma história para contar. Essa história precisa representar algo: trazer uma informação, ser edificante, emocionar e, às vezes, chocar.

- Qual a média de contribuições espontâneas que vocês recebem mensalmente? Não sei mensurar, mas são muitas. Hoje, tenho oito cartas que precisam ser abertas, e ainda nem olhei a caixa postal dos emails de eu, leitora.

- Os temas das contribuições são livres ou determinados pela Revista? Os temas são absolutamente livres. Chega de tudo por aqui: histórias de amor, de desespero, de alegria, de força. A redação só determina um tema quando promove o concurso Eu, leitora. Aí, pensamos em um assunto específico e aguardamos as contribuições. Todas as histórias são lidas. Depois, as finalistas são analisadas por um júri formado por jornalistas da revista (ou da editora). Desses finalistas, são eleitas três histórias. As vencedoras, em geral, são premiadas com uma jóia. O concurso não tem data para acontecer, mas costuma ser lançado na revista uma vez por ano.

- Como é feita a seleção do que é publicado? Quais os critérios?

São os que mencionei lá em cima. A história precisa ter um apelo, seja ele qual for. Então, pode ser um tema chocante (ex: o dia em que transei com 
dois irmãos ao mesmo tempo), amor com todos os ingredientes (amor, é claro, doença e morte), informação (a história da moça que foi submetida a uma cirurgia com célula-tronco e teve sua vida mudada para melhor --essa história fez sucesso, muitos leitores nos procuraram pedindo os contatos dos médicos que dominam a técnica), edificante (a história de uma mulher que adotou uma criança soropositiva)... Raramente o apelo é a temperatura da notícia, mas às vezes isso acontece, como foi no caso do tsunami (entrevistamos uma sobrevivente brasileira). O fato é que essa seção está preocupada em ouvir a versão daquela pessoa que tem uma história interessante para contar, seja ela qual for.

- Os textos recebidos são publicados integralmente ou sofrem edições? Se sim, com que objetivo? Quem faz as alterações/adequações? Evidentemente que os textos recebidos não são publicados integralmente. Se a história interessa ao conteúdo da revista, um repórter (ou mesmo um editor) entra em contato com o autor da história para entrevistá-lo. Dados dessa história são checados e, por fim, o texto é produzido por algum jornalista. Bem, o objetivo é o mais óbvio possível. Os textos que recebemos são textos, às vezes muito bem escritos, mas fora de uma ordem lógica para a publicação. Em geral também, as pessoas que escrevem deixam "buracos" nos textos que elas vivenciaram --isso é muito comum. Você conhece tanto aquela história que deixa de informar um monte de coisas, imaginando que quem está lendo também conhece aquela história. Existem também as questões técnicas: textos muito resumidos ou longos demais... Então, o caminho é esse: o autor é entrevistado, o texto é escrito por um repórter e depois, se necessário, editado pelo editor.

- Vocês guardam os relatos iniciais (os enviados pelo público)? Sim, claro. Os relatos são guardados e muitas vezes guiam a reportagem.

É isso. Qualquer coisa, me procure na semana. Até. Fernanda

Muito obrigada,

Ligia Maria Trigo-de-Souza

Doutoranda - ECA-USP 


\section{Anexo 3}

----- Mensagem encaminhada de mpassador -----

Data: Tue, 23 Oct 2007 15:29:47 -0300

De: Marina Morena Costa Passador - Redação Marie Claire - Editora Globo Endereço para Resposta (Reply-To): Marina Morena Costa Passador - Redação Marie Claire - Editora Globo

Assunto: ENC: Boa personagem!

Para: litrigo

Oi, Lígia.

Logo abaixo segue o primeiro e-mail que a Giulia Costa mandou para a redação. Vou pesquisar as demais história e te aviso se temos os relatos originais.

Um abraço,

Marina

:: Marina Morena Costa Passador

Revista Marie Claire - Editora Globo

Av. Jaguaré, $1485,4^{\circ}$ andar

05346-902 - São Paulo - SP - Brasil

www.marieclaire.globo.com <http://www.marieclaire.globo.com/>

-----Mensagem original-----

De: Redação Marie Claire - Editora Globo

Enviada em: sexta-feira, 11 de maio de 2007 12:32

Para: Rosane Queiroz da Costa - Redação Marie Claire - Editora Globo; Fernanda

Cirenza - Redação Marie Claire - Editora Globo; Silvana Tavano - Redação Marie Claire

- Editora Globo; Marisa Adan Gil - Redação Marie Claire - Editora Globo; Milly Lacombe

- Redação Marie Claire - Editora Globo

Assunto: Boa personagem! 
Pode ser um Eu, Leitora ou um jeito bacana de falarmos de células tronco.

Querem que eu peça pra ela contar mais?

Bjs,

Marina

-----Mensagem original-----

De: Giulia Maria Silva da Costa

Enviada em: quinta-feira, 10 de maio de 2007 01:16

Para: Redação Marie Claire - Editora Globo

Assunto: Mensagem enviada pelo site $>>$ Marie Claire

\section{FALE CONOSCO >> Marie Claire}

Nome: Giulia Maria Silva da Costa

Email: $X X X X X X X X X X$

Idade:38

Sexo:

Telefone: $X X X X X X X$

Cidade: Salvador

Estado: Bahia

País:

Permite publicar: $Y$

Assina: Não assino

Mensagem: sou a primeira paciente do mundo a fazer uma cirurgia que une célula tronco adulta com osso esponjoso ou adulto. Já faz dois anos q a cirurgia aconteceu e é um sucesso total. Recuperei $8,5 \mathrm{~cm}$ do femur esquerdo e flexiono meu joelho,antes sem flexão alguma, por mais de 15 anos. Gostaria de contar a minha estória, mas não sei como. Vcs poderiam me ajudar? 


\section{Anexo 4}

Entrevista com Flávia Martinelli, editora, concedida em 31/10/07.

Pergunta $(P)$ : Os textos publicados não são os originais que as pessoas mandaram, não é?

Resposta (R): Não, não tem como. É preciso trabalhar, apurar, é feita uma entrevista... Há momentos em que o repórter vai pessoalmente à casa do leitor, fotografa... As fotos em geral são nossas, com exceção das que arquivo dos leitores. A gente tenta usar fotos de acervo pessoal para comprovar o relato do leitor. $\mathrm{E}$ há matérias em que a gente pega mentiras. A gente vai checar a história e no espelho que a gente monta da edição, as matérias vão caindo porque a história não tem nenhuma comprovação e soa inverossímil, por exemplo. E às vezes a matéria soa inverossímil, mas a gente entrevista a testemunha e foi real. É o caso desta matéria "Meu namorado me traiu comigo mesma". Basicamente ela criou um perfil no MSN e, namorando o cara, se passou por outra mulher, marcou encontro com ele, foi no encontro e desmascarou. E ele passou meses paquerando essa menina inventada, dizendo que não tinha namorada nenhuma, que não estava saindo com ninguém. A gente confirmou a história com o "Anderson". Ele pediu para não aparecer na revista, ele pediu para ter a foto dele desfocada, ele não quis ser identificado, a gente mudou o nome dele a pedido dele.

A história que veio originalmente era uma história de umas 10 linhas, assim, era uma história meio simplória. Em geral, é assim.

$(P)$ : Vocês guardam esses relatos?

(R): Guardamos.

(P): Tem como termos uma cópia de um desses relatos (preservando, é claro, os dados pessoais) só para anexar à tese e ter como comparar com as matérias?

(R): Tem, tem sim. Mas você está me dizendo que está focando nas matérias de capa. O curioso é que na "Sou + eu!" a única matéria que é sugerida pela redação é justamente essa. Porque a matéria de capa é muito mais uma questão de marketing e vendas, do que vai chamar a atenção na banca naquela semana em especial diante de toda a nossa concorrência, diante de todos os assuntos relevantes da semana do que necessariamente a sugestão do leitor. A matéria de capa nem sempre vem do leitor para a redação. Eu encomendo para o 
repórter que coleta as informações, vai buscar o personagem, explica a proposta da revista, colhe o depoimento... Essa revista quebrou todos os paradigmas: a gente paga o leitor, não é?

$(P)$ : Como é que surgiu a idéia?

(R): A idéia surgiu das revistas inglesas. Tenho até aqui um material para você que conta um pouco essa história e cita todas as revistas inglesas em que ela foi baseada. Basicamente, são revistas que, na Inglaterra, vendem horrores. São as revistas mais populares. São todas revistas que fazem um tremendo sucesso de público classe média baixa inglesa (working class). Lá elas vendem mesmo. Só que o conteúdo editorial inglês vai muito além da proposta da "Sou + Eu!", porque o mercado é outro, o leitor é outro... As histórias são mais cabeludas, picantes e eles se expõem de uma maneira que o brasileiro não se expõe. É bem trash, mais estilo tablóide. E eles pagam o leitor e é um grande sucesso inglês. A adaptação para o Brasil mudou completamente a proposta editorial. É como se fosse assim: ok, nós usamos o modelo de negócio, de pagar o leitor, de fazer a revista inteira com conteúdo do leitor, porém o conteúdo editorial é completamente diferente. O leitor brasileiro é muito mais conservador, ele quer sair bem na fita, esse é um momento de orgulho para o leitor. O brasileiro tem muito humor e a gente descobriu isso fazendo a revista: tem uma porção de histórias que mandam prá nós que são muito engraçadas, são situações hilárias. E histórias edificantes, também, histórias de superação, de luta, um grande feito. A primeira pessoa de uma família que conseguiu chegar à Universidade, que rompeu com aquele ciclo de miséria, tudo. Neste estilo temos dezenas de cartas. E as dietas, histórias de traição.

(P): E os critérios para seleção?

(R): Os critérios para publicação são histórias com desfecho positivo. A gente parte do pressuposto que aquela história, de alguma maneira, ainda que às vezes torta, é exemplar. A história tem que ter começo, meio e fim, a gente fecha a narrativa. Às vezes o leitor não sabe direito o que quer contar e aqui na redação a gente tem que fazer uma grande peneira. Por exemplo, teve uma leitora que mandou uma história longa: eu nasci, eu cresci, meu pai, minha mãe, minha vida foi dura, etc etc etc. Aí eu lutei, eu vim prá São Paulo e aí eu fui estudar, terminei o colegial, consegui um emprego num consultório dentário. Lá no consultório dentário, eu recebia as cartas e me apaixonei pelo carteiro e mandava cartas para mim mesma. Era uma linha e era a matéria. É o olhar do repórter, o olhar da redação sobre o que existe de novidade no material que a gente coleta. 
$(P)$ : Eles chegam a ver o texto antes de ser publicado, não?

(R): Não, ele vêem na banca. A gente grava todas as entrevistas. Mas se a gente oferecer para o leitor a oportunidade da edição, você contenta o personagem mas pode não contentar o público. A pessoa pode repensar dez vezes o que ela disse e não querer mais que detalhes sejam publicados. Ou pode se arrepender, voltar atrás.

$(P)$ : Vocês recebem cartas que já estão praticamente prontas para serem publicadas?

(R): Às vezes sim mas não é freqüente e independe do nível sócio-cultural da pessoa. Há pessoas que são detalhistas ao extremo... É raro não ter um buraco, mas já aconteceu de histórias extremamente bem contadas. Teve a história de um Juiz, do interior do Tocantins, que vivia cercado de seguranças porque já tinha condenado mais de 120 traficantes. O texto estava maravilhoso, superbacana, quase fechado. Ainda assim a gente foi fazer a matéria, houve adaptações porque ele estava falando juridiquês. Nós respeitamos a variação lingüística; todo repórter é orientado a respeitar. Uma empregada doméstica falando, ele tem o direito de falar como empregada doméstica. Nós não reproduzimos erros de português, mas se tiver lá uma palavra que fuja do vocabulário, do léxico daquela pessoa, eu edito na hora: opa! Quem é que está escrevendo? É a repórter ou é a Maria das Dores? Na revista a gente usa inclusive variações lingüísticas regionais: tchê, oxente, trem... A gente usa "prá", uma porção de coisas que depois volta do departamento de revisão da editora apontados como erros e a gente não liga.

(P): Qual é a média que vocês recebem hoje de cartas?

(R): Olha, é que tem que fazer uma diferença. A revista, ela não tem só histórias, ela tem piadas, perguntas, dicas... então, falando de colaborações em geral, são umas 5 mil por semana.

(P): É muita coisa.

(R): É sim, porque a pessoa pode mandar por carta ou pelo site. No site a gente criou um sistema inédito de coleta de material que se chama Sistema de Atendimento ao Leitor. Existe para todas as revistas, mas para nós, os repórteres foram treinados. Não existe uma pessoa que atende ao leitor. Todos os repórteres tem acesso a uma base de dados. Você manda sua historinha, sua receita, o que for, pelo site e vai cair numa grande base de dados e lá fica tudo classificado por seção. Para participar, a pessoa tem que preencher um cadastro no Passaporte Abril, com nome, endereço, telefone, $\mathrm{ClC}$, RG, tudo isso. Isso já inibe muito a que as pessoas inventem coisas ou queiram brincar. A pessoa tem 
que aceitar um Código de Ética e quando ela posta a sua história ela abre mão de seus direitos autorais, ela já é informada que o conteúdo será checado por uma equipe, que pode ser editado, enfim... É muita coisa e às vezes são os mesmos leitores com várias colaborações e a gente tem uma regra: o mesmo leitor só aparece na revista após quatro meses da outra aparição, porque senão a revista fica sendo feita só por um mesmo grupo. E sendo paga a revista a gente tem também que dar chance a um maior número de pessoas. Daí os repórteres lêem as contribuições, separam e trazem para a reunião de pauta. Cada repórter conta as histórias que selecionou e elas são pré-aprovadas ou não. Há momentos em que uma história não emplaca porque há pouco tempo teve outra parecida, ou porque é interessante, mas é anti-ética, ou causa risco. A gente sabe que está lidando com um público, para quem vale o que está escrito, então a gente tem que ter uma grande responsabilidade.

$(\mathrm{P})$ : Tem temáticas fixas?

$(\mathrm{R})$ : Tem sim. Dieta é uma delas. Não tem uma regra fechada, mas acaba tendo. O fato é que sempre tem romance, histórias de amor - com final feliz, tem de superação, de ascensão... E o que a gente chama de ascensão, às vezes é bem modesto, como a história de uma senhora que começou a fazer lasanha na casa dela e hoje tira dois mil reais por mês e faz a festa... E ela dá a receita dela. Tem matérias de sexo mas não é sempre não.

$(\mathrm{P})$ : Viagem?

$(\mathrm{R})$ : Viagem, não, Às vezes, não sempre. Quando tem, é legal.

E o que acontece com as histórias que vocês não aproveitam?

Então, o SAL tem um sistema que é muito bacana. A história chega até nós. O repórter que lê a matéria tem opções: ele pode recusar a matéria - e aí vai um e-mail imediatamente pro leitor avisando que a matéria foi negada e o motivo pode ser, e aí vai uma lista de motivos (inadequação editorial etc), mas não fique chateado, continue colaborando etc. É uma cartinha singela que não explica exatamente o motivo, mas dá algumas possibilidades. O repórter também pode escolher "pré-selecionada", que é a história que será levada á reunião de pauta. Ela corre o risco de cair na reunião de pauta ou de emplacar. Se ela emplaca, vai para a checagem. Mais uma vez ela pode cair ou emplacar. E o leitor acompanha. Cada vez que a matéria muda de status, o leitor recebe uma mensagem. E num terceiro momento, com a história publicada, o próprio Serviço de Atendimento ao Leitor vai gerar uma lista com o valor que ele tem a receber e ele recebe um vale postal para retirar o pagamento na agência dos Correios mais próxima. 
(P): E se for por carta?

$(R)$ : Aí vai ter uma funcionária específica para inserir as informações da carta no sistema. E assim que ela digita, ela manda uma carta para o leitor. 


\title{
Anexo 5
}

\author{
De: Daniele Zebini \\ Enviada em: segunda-feira, 5 de novembro de 2007 17:33 \\ Para: Flavia Martinelli \\ Assunto: ENC: Material de Prycilla J ordan Santander
}

\section{Mensagem recebida de Daniele Zerbini}

Bom dia meu nome é Sara, sou uma ex garota de progrma e gostaria muito de contar a minha história, pois acredito que servirá de lição para todas as mulheres que pensam em desistir de sua felicidade e que acreditam que não tem forças para mudarem sua vida.Posso dizer que o filme uma linda mulher aconteceu na minha vida.

Tudo começou quando tinha 19 anos de idade e resolvi entrar em um curso para me formar comissária de bordo, acabei conhecendo um aluno que estava fazendo curso para ser piloto de Avião e acabamos nos apaixonando e começamos a namorar. Como estávamos desempregados arrumamos um emprego em um site e começamos a trabalhar juntos na mesma empresa porém ele tinha sérios problemas com a sua mãe ela era super protetora, controladora e me odiava pois eu era de uma família classe média e ele era de uma família muito rica.Ele acabou saindo de casa pois a mãe dele não me aceitava, como ele não tinha para onde ir acabou ficando na casa dos meus pais até ele achar um outro lugar para ele. Porém a mãe dele fez da minha vida um inferno, ela achava que a culpa era minha dele Ter saido de casa, ela ia no meu emprego e fazia escandalo na porta da empresa, ligava para a minha chefe para falar de mim, até tentar agredir a minha mãe ela tentou, já tive que chamar a polícia para tirá-la da frente da casa que eu morava .Um dia ele me pediu em casamento, eu aceitei ,meu pai vendo nossa situação e mesmo contra sua própria vontade ele aceitou que eu me casasse e mais ainda ele pagou toda a festa, nos deu a lua de mel tudo paga e como nós não tinhamos condições fomos morar com meus pais.Depois que nos casamos ele foi despedido, resumindo ele ficou um ano desempregado e detalhe ele não procurava emprego e só ficava assistindo televisão, ele não se importava e nem procurava emprego, quem estava nos sustentando era meu pai, depois de muito custo ele arrumou um emprego, ganhava muito pouco mais era melhor que nada, depois eu fui despedida. Ele arrumou um outro emprego e alugamos um apartamento porém ele foi transferido para Minas Gerais e eu tive que ficar morando sozinha em São Paulo, aí que o inferno começou.

Ele ficava mais de 2 meses sem vim para casa e quando vinha ficava uns 3 dias, porém eu a cada dia ele ficava mais frio, me tratava mal, e não mandava mais dinheiro para pagar as contas. Um dia recebi uma ordem de despejo, eu desesperada liguei para ele e contei , ele com a maior cara de pau me disse que não tinha dinheiro e que não podia fazer nada e desligou o telefone. Na mesma semana descobri que ele tinha uma amante me senti abandonada, humilhada. Me arrumei bem bonita e fui até uma boate muito famosa em São Paulo e eles me contrataram na hora e comecei a trabalhar. Depois ele me ligou e disse que não voltaria mais para SP e resolvemos nos divorciar, me lembro que eu arquei com tudo e ainda tive que dar uma quantia em dinheiro para ele poder assinar o divórcio, ou seja o homem que eu pensei que era o príncipe encantado da minha vida na verdade era um canalha chantagista.

Alguns dias se passaram e um certo dia conheci um homem, muito charmoso, conversamos a tarde toda neste dia, e acabei fazendo um programa com ele. Ele me ligava e saíamos todos os dias, eu percebi que algo estava diferente pois ele me tratava como se eu fosse a namorada dele.Um ele se declarou para mim, disse que me amava, que só pensava em 
mim, e que queria que eu fosse sua namorada e que não conseguia suportar a idéia de eu estar com outro homem, mesmo que fosse a trabalho. Eu fiquei assustava e pedi um tempo para pensar, depois de uma semana falei $\mathrm{cm}$ ele e disse que aceitaria pois eu estava gostando dele.Eu deixei de ser garota de programa e começamos a namorar, voltei a morar na casa dos meus pais, e também voltei a estudar estou fazendo faculdade, estou muito feliz e acredito que eu ainda serei muito mais feliz, estamos noivos e vamos nos casar. Hoje eu o amo muito. 


\section{Anexo 6}

Data: Tue, 23 Oct 2007 15:23:29 -0200

De: msmeado

Assunto: Re:tese usp - Mídia e Histórias Pessoais

Para: litrigo

Boa Tarde!

Ligia Maria,

segue em anexo a sua solicitação. Qualquer dúvida estou a disposição.

Att,

José Roberto Gama

\section{A LIGIA MARIA}

QUANDO E COMO SURGIU O QUADRO.

NA VERDADE, ESSA SESSÃO DO PROGRAMA ELI CORREA, NÃO COMEÇOU COM ESTE TITULO 'QQUE SAUDADE DE VOCÊ' E SIM COMO ' RECADO MUSICAL, ISSO HÁ MUITOS ANOS ATRÁZ MAIS DE 20.

A IDEIA SURGIU PORQUE OS OUVINTES MANDAVAM CARTAS, E NELAS OFERECIAM MUSICAS PRA ALGUEM QUE ESTIMAVAM MUITO, MAIS OU MENOS ASSIM, TIPO PARQUINHO DE DIVERSÕES, OU QUERMESES COM SOM NO LOCAL ONDE O RAPAZ ACANHADO, SEM SABER COMO CHEGAR NA GAROTA, MANDAVA NO SERVIÇO DE ALTO FALANTE DO PARQUE OFERECER UMA MUSICA PRA MOÇA QUE ESTAVA VESTIDA DE CALÇA JEANS AZUL E UMA BLUSA COR DE ROSA, E O CABELO ARRUMADO DE TAL JEITO. O LOCUTOR DO PARQUE ENTÃO DIZIA;

“ATENÇÃO GAROTA QUE ESTÁ USANDO CALÇA JEANS AZUL E BLUSA COR DE ROSA, E QUE ESTÁ COM O CABELO ATÉ A CINTURA....ALGUEM OFERECE A VOCÊ ESTA MUSICA QUE VAMOS TOCAR, E QUE VAI A SEUS OUVIDOS COM MUITO AMOR E CARINHO’’.

NO CASO DO ELI NÃO ÉRA EXAMENTE ASSIM, MAS UM POUCO PARECIDO PORQUE ELE DIZIA ASSIM;

'’OIIII GENTE....TENHO EM MÃOS CARTA DO OUVINTE (FULANO DE TAL) QUE ESTÁ SOFRENDO MUITO, PORQUE A SUA NAMORADA (FULANA DE TAL) O TROCOU POR OUTRO. ELE DIZ AQUI QUE NÃO DORME DIREITO, QUE NÃO TEM VONTADE DE SE ALIMENTAR, TUDO ISSO PORQUE VOCÊ O DEIXOU. O POBRE RAPAZ ESTÁ MUITO 
ABORRECIDO. ELE QUER QUE VOCÊ VOLTE PRA ELE, E TODA VEZ QUE OUVE A MUSICA QUE VOCÊS OUVIAM JUNTOS ENTÃO ELE...CHORA, SOFRE MAIS AINDA. ELE PEDE UMA CHANCE...PELO MENOS PRA CONVERSAREM. A MUSICA QUE FAZ ELE LEMBRAR DE VOCÊ É ESTA....

(TOCA A MUSICA PEDIDA, E QUE MARCOU O NAMORO DO CASAL).

FORAM CARTAS ASSIM QUE A PRINCIPIO VINHAM COM POUCAS LINHAS, NO MAXIMO 5, QUE COM O PASSAR DO TEMPO FOI AUMENTANDO, OS OUVINTES PASSARAM A ESCREVER MAIS E AS CARTAS FORAM FICANDO MIAS LONGAS, E DO 'RECADO MUSICAL" PASSAMOS A CHAMA-LA DE CARTA DA SAUDADE, E A AUDIENCIA CADA VEZ MAIOR, O VOLUME DE CORRESPONDENCIA TAMBEM, E ASSIM ESSE QUADRO "QUE SAUDADE DE VOCÊ" FOI GANHANDO INDICE MUITO BOM NO I.B.O.P.E, E PASSOU A SER O LIDER DE AUDIENCIA NO HORÁRIO DAS 14.00 HS. ALIÁS É LIDER ABSOLUTO ATÉ HOJE, IMBATIVEL, NENHUMA EMISSORA CONCORRENTE CHEGA SEQUER PERTO DO ELI CORREA NESSE HORÁRIO.

COM REFERENCIA A SEGUNDA PERGUNTA, OU SEJA DEPOIMENTOS, RARAMENTE COLOCAMOS NO AR A PESSOA QUE ESCREVEU, NO ENTANTO EM ALGUMAS CARTAS, LIGAMOS PRA CASA DA OUVINTE OU OUVENTE, PARA QUE AO FINAL DA NARRAÇÃO, A PESSOA POSSA COMPLEMENTAR ALGUMA COISA QUE ESQUECEU DE MENCIONAR NA CARTA, OU PORQUE A PESSOA TEM NECESSIDADE DE PARTICIPAR DANDO SEU TESTEMUNHO QUE VIVEU TUDO AQUILO NARRADO PELO ELI CORREA. ( DÁ MUITA CREDIBILIDADE).

UMA OBSERVAÇÃO. QUANDO A PESSOA QUE ESCREVE SE ESTENDE MUITO NA SUA HISTORIA, AS VEZES TEMOS A NECESSIDADE DE INTERROMPER A NARRAÇÃO NO MEIO, CASO CONTRÁRIO A CARTA SE ENTENDERIA ATÉ AS 15 HORAS, O QUE C OMPLICARIA PRO ELI, DEVIDO OS COMPROMISSOS COMERCIAIS QUE SE ACUMULARAIM. (EM, GERAL OS OUVINTES NÃO GOSTAM DESSA PRATICA, PORQUE FICAM NO SUSPENSE, QUERENDO SABER O DESFECHO DA MESMA. MAS ISSO É RARO DE OCORRER.

COM REFERENCIA A MEDIA DE CORRESPONDENCIA PRA ESSA SESSÃO, É MUITO GRANDE. MAIS OU MENOS 80 A 90 CARTAS POR SEMANA.

NÃO EXISTE UM CRITÉRIO RIGOROSO. TODOS QUE ESCREVEM SÃO MERECEDORES DE MUITA ATENÇÃO, AFINAL GASTAM COM SELO, TAMBEM TEM O FATO DE TIRAR UM TEMPO PRA ESCREVER SUA CARTA, E ISSO TUDO TEM QUE SER RECONHECIDO PELA PRODUÇÃO. NÃO EXISTE SORTEIO DE ESCOLHA DE CADA CARTA, O QUE ACONTECE É QUE NEM SEMPRE É POSSIVEL DAR VAZÃO IMEDIATA A ESSE VOLUME TÃO GRANDE DE CORRESPONDENCIA, MAS NÓS SEMPRE 
MANTEMOS CONTACTO COM QUEM ESCREVE, POIS AS PESSOAS COLOCAM ENDEREÇO, CEP. E TELEFONE TAMBEM.

QUANTO AO FATO DAS CARTAS SOFREREM EDIÇÕES, ISSO REALMENTE ACONTECE. O OUVINTE ESCREVE DO JEITO DELE, E SENDO ASSIM, AS VEZES NO AUGE DA EMOÇÃO DO QUE ESTÁ CONTANDO, SE ATRAPALHAM, JÁ COLOCAM O FINAL DA CARTA EM LUGAR QUE AINDA NÃO É O MOMENTO, PULAM LINHAS, INVERTEM NOMES, ERRAM NAS DATAS, ALEM DA CALIGRAFIA NÃO SER DAS MELHORES, E SE NÃO PRETARMOS ATENÇÃO, CORREMOS O RISCO DE NÃO AGRADAR QUEM A ESCREVEU. POREM NÃO FUGIMOS DO FATO, DA HISTORIA, TUDO É QUESTÃO APENAS DE CORREÇÕES NECESSÁRIAS.

ESSAS CORREÇÕES SÃO FEITAS PELO PRODUTOR DA CARTA QUE HÁ MAIS DE 27 ANOS ESTÁ JUNTO COM O ELI CORREA, OU SEJA, O JOSÉ ROBERTO GAMA.

TODA EMISSORA DE RÁDIO, É OBRIGADA A MANTER EM ARQUIVO SUA PROGRAMÇÃO TODA DURANTE PERÍODO DE 30 DIAS, ISSO É LEI, APÓS O QUE, ENTÃO E DESFEITA A GRAVAÇÃO. SE DENTRO DESSE PERÍODO A OUVINTE SOLICITAR UMA COPIA DA NARRAÇÃO DE SUA CARTA, REMETEMOS EM CD.

COMO AS VEZES A OUVINTE PEDE SIGILO, OU SEJA NÃO DESEJA SEU NOME REVELADO NO FINAL DA CARTA LIDA E NEM ENDEREÇO, ENTÃO RESPEITAMOS ESSA VONTADE, E NÃO DIVULGAMOS, APENAS DAMOS NO AR AS INICIAIS E O BAIRRO.

PARA O SUCESSO DA 'CARTA DA SAUDADE' CONTAMOS AINDA COM A SONOPLASTIA DE UM EXCELENTE PROFISSIONAL QUE TAMBEM TRABALHA COM A GENTE HÁ MUITOS ANOS, QUE É O FLAVIO RANGEL. CADA CARTA TEM UMA MOTIVAÇÃO, E A SONOPLASTIA (EFEITOS MUSICAIS) É DE RELEVANTE IMPORTANCIA PARA O RENDIMENTO DA NARRAÇÃO DO ELI CORREA, QUE VIVE CADA SITUAÇÃO, COMO ELE PROPRIO TIVESSE VISUALIZANDO, SE INCORPORANDO DENTRO DO QUE A PESSOA ESCREVEU.

ESPERAMOS TER COLABORADO UM POUCO NOS ESCLARECIMENTOS SOLICITADOS ATRAVÉS O SEU E-MAIO, E DESEJAMOS FELICIDADE E MUITO SUCESSO NO SEU CURSO DE DOUTORADO EM COMUNICAÇÃO.

UM ABRAÇO:

JOSÉ ROBERTO GAMA.

PRODUÇÃO ELI CORREA. 


\section{Anexo 7}

Data: Thu, 25 Oct 2007 12:06:31 -0300

De: Galvao França

Assunto: Re: informa

Para: litrigo

Olá Lígia Maria

Respondo as perguntas logo abaixo :

Grato

Galvão França

Diretor

Tel. $x x x x-x x x x$

Fax. $X x x x-x x x x$

De: litrigo@usp.br

Para: gfranca@sbt.com.br

24/10/2007 17:52 cc:

Assunto: informa

Olá, Galvão,

quem me passou seu contato foi o Marcos Cripa...

Eu faço doutorado em Comunicação na USP e minha tese é sobre o espaço que os veículos de comunicação oferecem para o público narrar suas histórias pessoais. Estou trabalhando com estudos de caso em cada meio de comunicação e em televisão, escolhi mostrar o "Casos de Família", que estou acompanhando todo este mês mas preciso também de mais 
algumas informações. Você poderia responder?

- Como e quando surgiu o programa?

O formato deste tipo de programa é antigo. Aqui ele começou faz 3 anos através de uma produtora Chilena, que produz um programa a 10 anos no Chile e tem uma forma diferente de pesquisa dos casos.

- Os casos apresentados vêm espontaneamente ou é a produção de vocês que localiza as histórias e os personagens?

Nós temos uma equipe de estagiários que recebem os temas dados por nós e vão em busca dos casos. Estes casos são entrevistados por eles e depois novamente entrevistados por uma equipe mais experiente, se o caso se encaixar no tema, tiver consistência e for verdadeiro, entra no programa

- Vocês recebem muitas sugestões do próprio público? Qual a média mensal? As vezes o publico nos ajuda com algumas sugestões, mas na maioria das vezes os temas são criados pela produção .

- O que é mais freqüente no programa: mais (e temas) enviadas pelos próprios telespectadores ou mais material sugerido e levantado pela produção de vocês?

Como falei anteriormente , a maioria dos temas são sugeridos pela produção

- Os temas são livres ou há algum tipo de restrição?

Os temas abrangem todos os tipos de problemas ou situações, não havendo restrição nem censura alguma .

- Como é feita a seleção do que é veiculado (temas e personagens)?

Quais os critérios?

Os participantes passam por entrevistas para sabermos se os casos são reais , e se estão dentro dos temas. Em cada entrevista é dada uma nota e as maiores notas entram no programa.

- Qual a dinâmica para a apresentação dos casos pós-seleção? Há alguma 
orientação aos participantes, como por exemplo, pontos que eles deveriam enfatizar?

Antes da gravação, é feita uma revisão dos fatos com os participantes para tentarmos deixar claro os pontos mais importantes de cada história .

- Vocês guardam as sugestões feitas pelo público (as cartas ou e-mails em que sugerem temas ou contam histórias pessoais)?

Sim , pois uma historia que hoje não se enquadra , amanhã pode se encaixar em outro tema .

- O formato impõe algum tipo de restrição à apresentação dos casos? Se sim, qual?

A única restrição que o formato impõe , é com relação a ética e educação, o programa não permite xingamentos e palavrões pois o intuito do programa não é promover a baixaria e xingamentos .

Espero ter podido colaborar com sua tese.

muito obrigada,

Ligia Maria Trigo-de-Souza

Doutoranda - ECA-USP 


\section{Anexo 8}

----- Original Message -----

From: "Juliano SP450"

To: "Ligia Trigo"

Sent: Monday, June 19, 2006 11:23 AM

Subject: Re: sp 450

oi lidia que bacana. será uma honra.

a proposta do site foi funcionar como uma alternativa para os espaços de convivência diários que estão desaparecendo. curiosamente estamos mais pertos uns dos outros nos prédios, mas os relacionamentos, os laços de solidariedade, o capital social - bem na linha de como a jane jacobs fala disso - vem se dissolvendo. o vivasp.com é uma comunidade para vizinhos online; passamos tempo *jogando conversa fora* nos nossos *portões virtuais*.

ele foi criado no contexto do aniversario de 450 anos de sp, primeiro porque eu estava voltando para a cidade e queria saber o que leva pessoas a viverem aqui, o que nos caracteriza enquanto paulistanos, e também porque a efeméride favorecia que o projeto fosse abraçado por um veiculo de midia tradicional e estabelecido, me dando a oportunidade de emplacar um case.

o site foi ao ar em agosto de 2003. os boletins começaram a ser transmitidos pelas rádios eldorado am e fm em novembro desse ano. os boletins saíram do ar da eldorado fm em meados de 2004. os boletins continuam sendo transmitidos 3x ao dia pela eldorado am, ao longo da programação, de segunda a domingo, com reprise no programa sao paulo de todos os tempos, do geraldo nunes.

o projeto sempre recebeu entre 10 e 200 relatos por mês, sem contar os textos publicados nas áreas de comentários. esse conteúdo permitiu que o site sempre tivesse cinco textos novos na capa de segunda a sexta, desde que foi criado. estamos chegando à marca de mil relatos enviados espontaneamente.

o unico profissional que cuida do projeto sou eu, apesar de eu nao ser jornalista. no começo o projeto contou com a ajuda de uma estudante de jornalismo que trabalhou no site como voluntária. mas em termos editoriais, o regulamento do site é que o texto seja modificado o mínimo, apenas para que os relatos façam sentido para o leitor. a maior parte do trabalho consiste em limpar a formatação de html, fazer correçoes estéticas nos textos e editar e publicar as fotos.

o projeto continua em funcionamento: $\underline{\text { www.vivasp.com }}$

bom, eu inscrevi o site em um concurso recentemente e acho que esse documento pode responder a essas perguntas preliminares. se voce tiver outras dúvidas, me avisa. 
beijos

js

Ligia Trigo wrote:

$>>$ oi, Juliano,

$>>$

$>>$ tudo bem? Como vai a vida?

$>>$

>> Bem, estou concluindo o Relatório de Qualificação do Doutorado e

$>>$ queria mesmo trabalhar com o SP 450 como caso a ser estudado nas

$>>$ Comunidades Virtuais...

>> Neste momento, estou precisando de algumas informações iniciais, você

$>>$ pode me ajudar?

$>>$ - Qual a proposta do site? Por que foi criado?

$>>$ - Quando foi criado e quanto tempo ficou no ar?

>> - Qual a média de relatos/mês recebidos?

$>>$ - Quantos foram publicados?

>> - Havia profissionais trabalhando na edição desses relatos?

$>>$ - Ainda é possível acessar o material? em qual URL?

$>>$

>> obrigada/bjs/ Ligia 


\section{Anexo 9}

----- Original Message -----

From: Lucia Freitas

To: Ligia Trigo

Sent: Tuesday, October 23, 2007 1:44 PM

Subject: Re: Blog Puzzle, um diário de viagem

\section{Oi, Ligia.}

Que honra!

O Puzzle te interessou porque é pessoal, imagino...

Te mando as respostas, com a condição de ser informada sobre tua tese e avaliações, ok? Em tempo: o título é Puzzle Diário

bj

Em 23/10/07, litrigo escreveu:

olá,

faço doutorado na USP e minha tese é sobre o espaço que os meios de comunicação oferecem para o público narrar sua própria história.

Através do ranking do Blogblogs cheguei ao seu Blog Ladybug e de lá ao Puzzle que me interessou. Você poderia me dar algumas informações sobre ele?

- Como e quando surgiu o blog?

Me inscrevi no blogger em 2001. A conta ficou parada até 2003, quando inciei o Puzzle Diário e o Jardim dos Narcisos (que usei para fazer um site sobre um final de amor meu). Hoje tenho 3 blogs próprios (Puzzle, Jardim e Ladybug Brasil) e participo de 4 blogs coletivos (goitacá, desabafo de mae, faça a sua parte e nossa opinião). Devo inaugurar um novo blog ainda este ano.

- Qual a sua proposta com o Blog? O Puzzle Diário nasceu para funcionar como um mapa digital dos movimentos da vida em mim. Resultado do meu processo de estudo de Anatomia Emocional, com Regina Favre, é atravessado por este conhecimento e minha insatisfação com o jornalismo que encontrava nas redações.

- Como você seleciona o que postar? Quais os critérios? Há temas pré-definidos? Ao mesmo tempo, há temas/assuntos proibidos?

Publico o que me toca, temas que acredito serem interessantes para "terceiros". No Puzzle, o registro é meu, partilhado com amigos mais próximos. Os temas de que gosto (saúde, ecologia, proteção animal, crescimento do humano, linguagem e metalinguagem, literatura e cinema, entre outros). Não há temas/assuntos proibidos. A única proibição é atacar terceiros - mas, confesso, já falei bem mal de um ex-namorado (sem citar o nome)

No Ladybug Brasil falo de web, gente, encontros, movimentos... o critério do Puzzle permanece: falo do que experimentei ou do que me toca. A proibição é idêntica. Se não gosto, não falo. 
- Qual a média de visitas que o Blog recebe mensalmente? Ih, No Puzzle é minusculo! 120/130 - são 6 por dia em média. Já o Ladybug Brasill, mais divulgado (meu "carro chefe") são quase 3 mil visitas/mês.

- E a média de comentários? Eles influenciam os posts seguintes? Há posts que aproveitam parte dos comentários (ou fazem referência a eles)? Os comentários do Puzzle são pessoalíssimos. Amigos comentando movimentos, em geral, novos conhecidos que vêm visitar e deixam registro.

No Ladybug a média de comentários varia muito... Nunca recebi muitos comentários - meus leitores são bem leigos com a ferramenta e vêm, em sua maioria de links diretos. Além disso, sou muito acompanhada pela comunidade blogueira. Nunca fiz post em cima de comentários. Em geral, os posts bacanas surgem de outras conversas, em grupos de discussão.

Isto acontece muito em outro blog, educacional, que instalei e administro para um grupo de estudos... Por lá os comentários realmente são instrumento de bate-papo e troca.

- No que se refere ao formato do Blog, quais são as limitações que você tem para publicar seus posts? Nenhuma. Posso escrever o quanto quiser, fazer "multimídia" com imagens, vídeos e música. Acho que isso é resultado do domínio de HTML, PHP e outras linguagens de programação que me permitem instalar e desinstalar ferramentas e buscar novas formas de interagir.

obrigada/

Ligia M. Trigo-de-Souza

ECA/USP - doutoranda

Lucia Freitas

"esta vida é uma viagem

pena eu estar só de passagem" P. Leminsky

http://www.ladybugbrazil.com

www.desabafodemae.com.br 